\title{
LOW-TEMPERATURE GEOTHERMAL WATER IN UTAH: A COMPILATION OF DATA FOR THERMAL WELLS AND SPRINGS THROUGH 1993
}

by

Robert E. Blackett

\author{
MECEIV \\ PEG 23 SE: \\ $0 \log 1$
}

This open-file release makes information, considered to be of value, available to the public during the lengthy review process. This report may not necessarily conform to formal Utah Geological Survey policy, technical review, or editorial standards, and therefore it may be premature for an individual or group to take action based on its contents. 



\title{
LOW-TEMPERATURE GEOTHERMAL WATER IN UTAH: A COMPILATION OF DATA FOR THERMAL WELLS AND SPRINGS THROUGH 1993
}

\author{
by
}

Robert E. Blackett

DISCLAIMER

\begin{abstract}
This report was prepared as an account of work sponsored by an agency of the United States Government. Neither the United States Government nor any agency thereof, nor any of their employees, makes any warranty, express or implied, or assumes any legal liability or responsibility for the accuracy, completeness, or usefulness of any information, apparatus, product, or process disclosed, or represents that its use would not infringe privately owned rights. Reference herein to any specific commercial product, process, or service by trade name, trademark, manufacturer, or otherwise does not necessarily constitute or imply its endorsement, recommendation, or favoring by the United States Government or any agency thereof. The views and opinions of authors expressed herein do not necessarily state or reflect those of the United States Government or any agency thereof.
\end{abstract}

This open-file release makes information, considered to be of value, available to the public during the lengthy review process. This report may not necessarily conform to formal Utah Geological Survey policy, technical review, or editorial standards, and therefore it may be premature for an individual or group to take action based on its contents. 


\section{CONTENTS}

DISCLAIMER $\ldots \ldots \ldots \ldots \ldots \ldots \ldots \ldots \ldots \ldots \ldots \ldots \ldots \ldots \ldots$

ABSTRACT $\ldots \ldots \ldots \ldots \ldots \ldots \ldots \ldots \ldots \ldots \ldots \ldots \ldots \ldots$

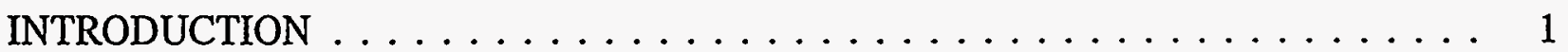

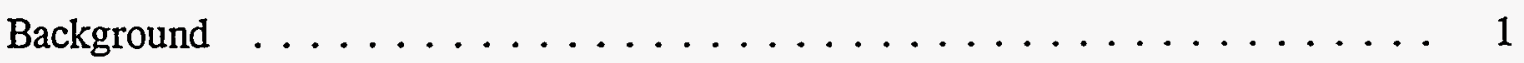

Current Program $\ldots \ldots \ldots \ldots \ldots \ldots \ldots \ldots$

DESCRIPTION OF GEOTHERMAL AREAS . . . . . . . . . . . . . . . 2

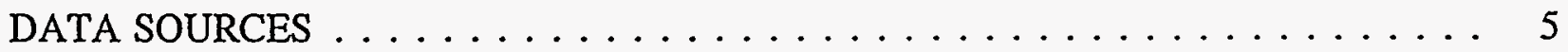

Previous Geothermal Studies ................... 5

The USGS's WATSTORE Database ................... 6

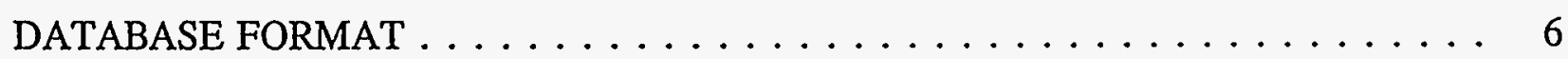

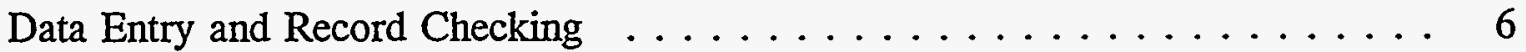

Water Analyses Checking Procedure $\ldots \ldots \ldots \ldots \ldots$

Descriptions of Final Products ................... 9

FLUID CHEMISTRY $\ldots \ldots \ldots \ldots \ldots \ldots \ldots \ldots \ldots \ldots \ldots$

Abraham (Baker, Crater) Hot Springs, Juab County . . . . . . . . . . . . . 11

Meadow and Hatton Hot Springs, Millard County . . . . . . . . . . . . . . . . . 14

The Mountain Spa Resort, Wasatch County . . . . . . . . . . . . . . . . . . . 14

Blue Lake Spring and Bonneville Salt Flats, Tooele County . . . . . . . . . . . 14

Wilson Health Springs, Tooele County . . . . . . . . . . . . . . . . . . . 15

Dixie (La Verkin) Hot Springs, Washington County . . . . . . . . . . . . . . . . . 15

Third Water Hot Springs, Utah County . . . . . . . . . . . . . . . 16

RECOMMENDED FUTURE STUDY AREAS $\ldots \ldots \ldots \ldots \ldots \ldots$

Newcastle Area, Iron County . . . . . . . . . . . . . . . . . . . 16

Meadow-Hatton Area, Millard County . . . . . . . . . . . . . . . 17

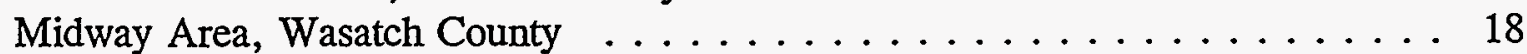

Wood's Ranch, Iron County $\ldots \ldots \ldots \ldots \ldots \ldots$

Thermo Hot Springs, Beaver County . . . . . . . . . . . . . . . . . . 19

Monroe Area, Sevier County . . . . . . . . . . . . . . . . . . . . . . . . . . . . . . . . . . . . . . . . . . . . .

Crystal Hot Springs Area, Salt Lake County . . . . . . . . . . . . . . . . 20

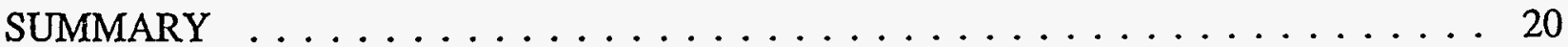

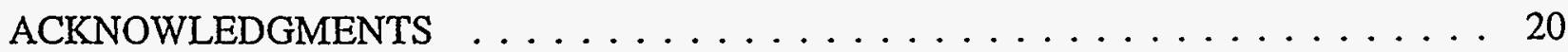

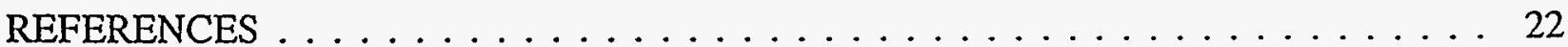


WELL AND SPRING NUMBERING-SYSTEM

USED IN UTAH $\ldots \ldots \ldots \ldots \ldots \ldots \ldots \ldots \ldots \ldots \ldots \ldots \ldots \ldots \ldots \ldots$

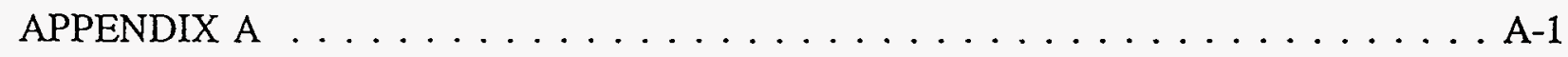

APPENDIX B $\ldots \ldots \ldots \ldots \ldots \ldots \ldots \ldots \ldots \ldots \ldots \ldots \ldots \ldots \ldots \ldots \ldots$ 


\section{FIGURES}

Figure 1: Index map of Utah showing distribution of thermal springs and wells, principal geothermal areas, and physiographic provinces. (3)

Figure 2: Flow chart showing the steps involved in compiling the geothermal database. (7)

Figure 3: Histogram of thermal wells and springs in temperature range categories. (12)

\section{TABLES}

Table 1: $\quad$ Selected geothermal wells and springs in Utah. (4)

Table 2: $\quad$ List of county codes used in record ID numbers. (8)

Table 3: Utah geothermal database, data field summary. (10)

Table 4: $\quad$ Complete analyses of water samples gathered during this study. (13)

\section{PLATES}

Plate 1: $\quad 1: 750,000$ map of wells and springs with temperatures of $25^{\circ} \mathrm{C}$ or greater.

Plate 2: $\quad 1: 750,000$ map of wells and springs with temperatures between $20^{\circ} \mathrm{C}$ and $25^{\circ} \mathrm{C}$. 


\section{DISCLAIMER}

This report was prepared as an account of work sponsored by the United States Government. Neither the United States nor any agency thereof, nor any of their employees, makes any warranty, expressed or implied, or assumes any legal liability or responsibility for the accuracy, completeness, or usefulness of any information, apparatus, product, or process disclosed, or represents that its use would not infringe privately owned rights. Reference to any specific commercial product, process, or service by trade name, trademark, manufacturer, or otherwise, does not constitute or imply its endorsement, recommendation, or favoring by the Utah Geological Survey, United States Government or any agency thereof. The views and opinions of the author expressed herein do not necessarily state or reflect those of the United States Government or any agency thereof. 


\begin{abstract}
The Utah Geological Survey compiled a database with information on thermal wells and springs in Utah that have temperatures of $20^{\circ} \mathrm{C}$ or greater. The database contains 964 records on 792 locations of wells and springs. Each record has 35 data fields and includes the location of the well or spring, its temperature, depth, flow-rate, and chemical constituents. The database was developed for use on DOS-based personal computers, and will provide users with immediate access to specific geothermal information in Utah. Resource maps of thermal wells and springs, derived from the database, are included in the report. The new database and resource maps could eventually include heat-flow information, bottom-hole temperatures from oil and gas wells, traces of Quaternary faults, and locations of young volcanic centers.

Seven areas are recommended in order of priority for additional studies based on development potential and the need for more resource information. Areas identified for likely near-term expansion or development of direct-use applications include Newcastle, the MonroeRed Hill area, the Meadow-Hatton area, the Midway area, and Crystal (Bluffdale) Hot Springs. Areas with potential for discovery of moderate-temperature resources for possible direct-use applications and/or binary power potential include Newcastle, Thermo Hot Springs, and the Wood's Ranch area.
\end{abstract}





\section{INTRODUCTION}

\section{Background}

The U.S. Geological Survey (USGS), in cooperation with the U.S. Department of Energy (DOE), compiled the first comprehensive database of geothermal wells and springs in Utah in support of two national geothermal assessments (Muffler, 1979; and Reed, 1983). The data for these assessments were incorporated into GEOTHERM (Bliss and Rapport, 1983), a main-frame computer system of databases and software used to store, locate, and evaluate information on geothermal systems. GEOTHERM received data until it was taken off-line in 1983. The USGS preserved these data and made them available for public use through a series of Open-File reports presenting information on source location, description, and water chemistry.

The Utah Geological Survey (formerly Utah Geological and Mineral Survey) helped with data compilation for GEOTHERM, and eventually published a state geothermal resource map in cooperation with DOE and the National Oceanic and Atmospheric Administration (Utah Geological and Mineral Survey, 1980). Based primarily on the work of Goode (1978), the map listed about 330 wells and springs included in GEOTHERM, showed heat-flow information from the work of Chapman and others $(1978,1981)$ and Sass and others (1974), and outlined areas of prospective value for geothermal exploration. Since the national geothermal assessments were completed in the early 1980 's, no new resource data have been gathered at a regional scale. The map also showed nine Known Geothermal Resource Areas (KGRAs), a classification for federal leasing based on competitive interests and/or geologic criteria. Since 1980, only three of these areas (Cove Fort-Sulphurdale, Roosevelt Hot Springs, and Crater Springs) still maintain the classification of KGRA. The others (Meadow-Hatton, Monroe-Joseph, Thermo, Lund, Newcastle, and Navajo Lake) were declassified because of either a lack of competitive interests or, in the case of Navajo Lake, a lack of an indicated resource.

\section{Current Program}

The Geothermal Division of DOE initiated the Low-Temperature Geothermal Resources and Technology Transfer Program, following a special appropriation by Congress in 1991, to encourage wider use of lower-temperature geothermal resources through direct-use, geothermal heat-pump, and binary-cycle power conversion technologies. The Oregon Institute of Technology (OIT), the University of Utah Research Institute (UURD), and the Idaho Water Resources Research Institute organized the federally-funded program and enlisted the help of ten western states to carry out phase one. This first phase involves updating the inventory of thermal wells and springs with the help of the participating state agencies. The state resource teams inventory thermal wells and springs, and compile relevant information on each source. OIT and UURI cooperatively administer the program. OIT provides overall contract management while UURI provides technical direction to the state teams.

Phase one of the program focuses on replacing part of GEOTHERM by building a new database of low- and moderate-temperature geothermal systems for use on personal computers. For Utah, this involved (1) identifying sources of geothermal data, (2) designing a database structure, (3) entering the new data; (4) checking for errors, inconsistencies, and duplicate records; (5) organizing the data into reporting formats; and (6) generating a map (1:750,000 scale) of Utah showing the locations and record identification numbers of thermal wells and 
springs (figure 1; table 1; plate 1). A separate but related task involved gathering and analyzing water samples from selected thermal springs and wells not adequately represented by existing data.

\section{DESCRIPTION OF GEOTHERMAL AREAS}

Utah comprises parts of three major physiographic provinces, defined by Fenneman (1931), each with characteristic landforms and geology. These include the Colorado Plateau, the Middle Rocky Mountains, and the Basin and Range provinces (figure 1). The Transition Zone extends through central and southwestern Utah, and contains physiographic and geologic features of both the Basin and Range and Colorado Plateau provinces. The Middle Rocky Mountains include the Wasatch Range and Uinta Mountains in the northeastern part of the state, comprising mainly pre-Cenozoic sedimentary and silicic plutonic rocks. The Colorado Plateau is a broad area of regional uplift in southeastern and south-central Utah characterized by essentially flat-lying, Mesozoic and Paleozoic sedimentary rocks. Scattered Tertiary and Quaternary volcanic rocks are present on the Colorado Plateau in south-central Utah, and some Tertiary intrusive bodies are present in southeastern Utah.

The Basin and Range Province is characterized by numerous north-south oriented, faulttilted mountain ranges separated by intervening valleys. Typical basin-ranges are asymmetric in cross section having a steep slope on one side and a gentle slope on the other. The steep slope reflects an erosion modified fault scarp and the range a tilted fault block (Hintze, 1988). Rocks within the Basin and Range vary widely in age and composition. Older rocks consist of a variety of Mesozoic and Paleozoic sedimentary rocks and their metamorphic equivalents. Cenozoic volcanic rocks and valley-fill units generally overlie the sedimentary and metamorphic

rocks. Valley-fill deposits consist mostly of late Cenozoic and Quaternary lake beds and alluvium as much as $3,000 \mathrm{~m}(10,000 \mathrm{ft})$ thick.

Comprising essentially the western half of Utah, the Basin and Range is separated from the Middle Rocky Mountains by the Wasatch Fault zone, and from the Colorado Plateau by the Transition Zone. Within the Basin and Range and the Transition Zone, east-west structural extension is thought to have taken place over the past 17 million years (Hintze, 1988). Prior to Basin and Range extension (during mid-Cenozoic time), voluminous, silicic volcanism with associated hydrothermal mineralization took place within several east-west trending belts (Stewart and others, 1977). After extension began, volcanism patterns changed to less-voluminous rhyolite and basalt spatially controlled by north-south Basin and Range faults. The very young volcanic rocks (less than $1 \mathrm{Ma}$ ), potentially related to geothermal resources, are found in a belt extending from west-central Utah through northwestern Arizona.

The worldwide average conductive heat flow to the earth's surface is about 61 milliwatts per square meter $\left(\mathrm{mW} / \mathrm{m}^{2}\right.$ ) for the continents (Williams and Von Herzen, 1974). Typical values for heat flow in the Basin and Range Province vary between 80 and $120 \mathrm{~mW} / \mathrm{m}^{2}$. The Colorado Plateau and the Middle Rocky Mountains provinces have heat-flow values near the average for the earth's surface (Sass and others, 1976; Sass and Munroe, 1974). 


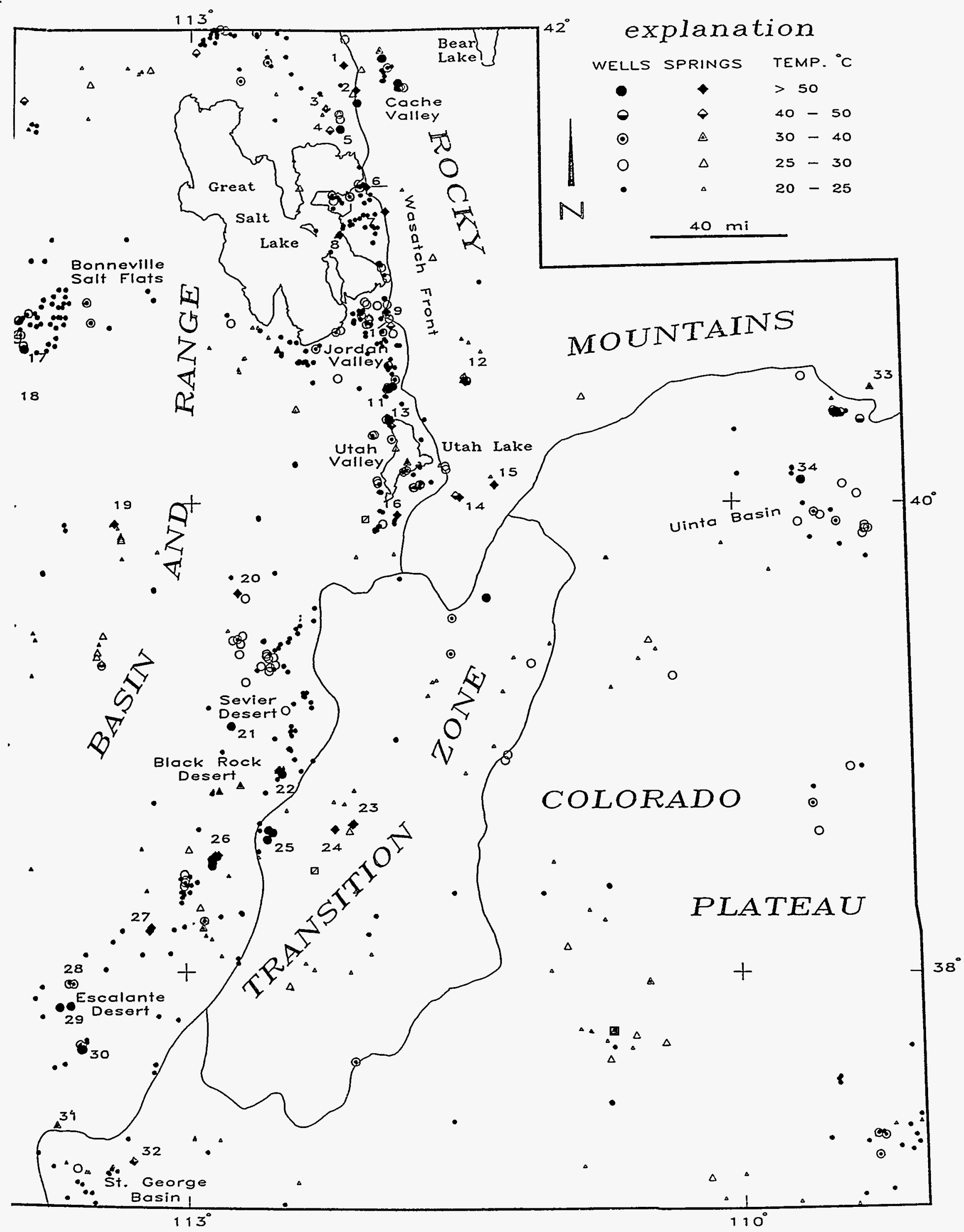

Figure 1. Distribution of thermal springs and wells, principal geothermal areas, and physiographic provinces in Utah. 
Table 1. Principal geothermal springs (S), wells (W), and areas (A) in Utah.

\begin{tabular}{|c|c|c|c|c|c|c|c|}
\hline NO. & NAME & MAP NO. & TYPE & $\begin{array}{l}\text { DISCHARGE } \\
\text { TEMP, }{ }^{\circ} \mathrm{C}\end{array}$ & $\begin{array}{l}\text { ESTIMATED } \\
\text { FLOW, L/min }\end{array}$ & $\begin{array}{l}\text { RESERVOIR } \\
\text { TEMP, }{ }^{\circ} \mathrm{C}\end{array}$ & DEPTH, $m$ \\
\hline 1 & Uddy & $\mathrm{BO}-42$ & $S$ & 53 & 6,000 & $55-90$ & -. \\
\hline 2 & Crystal Madsen & BO-29 & $S$ & 56 & 3,600 & $60-90$ & -- \\
\hline 3 & Little Mtn. & $\mathrm{BO}-22$ & $S$ & 42 & 1,700 & $50-80$ & -- \\
\hline 4 & Stinking & BO-18 & $S$ & 48 & 100 & $70-90$ & -- \\
\hline 5 & Chesapeak & $\mathrm{BO}-15$ & W & 74 & 150 & $70-80$ & 153 \\
\hline 6 & Utah & WE-22 & $S$ & 58 & 121 & $70-100$ & -- \\
\hline 7 & Ogden & WE-11 & $S$ & 58 & 20 & $70-100$ & -- \\
\hline 8 & Hooper & DA-14 & $S$ & 60 & -. & $80-120$ & -- \\
\hline 9 & Becks & SL-03 & $S$ & 55 & - & $60-100$ & -- \\
\hline 10 & Wasatch & SL-06 & $S$ & 42 & 240 & $50-90$ & -- \\
\hline 11 & Crystal Bluffdale & SL-47 & A & 58 & -- & $90-120$ & -- \\
\hline 12 & Coleman Midway & WS-04 & $A$ & 45 & 180 & $70-75$ & -- \\
\hline 13 & Saratoga & UT-11 & $S$ & 44 & 700 & $60-100$ & -- \\
\hline 14 & Castilla & UT-63 & $S$ & 40 & - & $50-90$ & -- \\
\hline 15 & Third Water & UT-70 & $S$ & 55 & -- & $65-100$ & -- \\
\hline 16 & Goshen Valley & UT-66 & $S$ & 61 & -- & $60-70$ & -- \\
\hline 17 & Bonneville DBW 3 & TO-96 & W & 88 & - & -- & 630 \\
\hline 18 & Blue Lake & TO-103 & $S$ & 29 & -- & $50-90$ & -- \\
\hline 19 & Wilson Health & TO-109 & $S$ & 55 & -- & $55-100$ & -- \\
\hline 20 & Abraham (Crater) & JU-15 & $S$ & 85 & 1,200 & $100-150$ & -- \\
\hline 21 & Neels RR & MI-65 & W & HOT & -- & $200(?)$ & 610 \\
\hline 22 & Meadow-Hatton & MI-80,84 & $S$ & 63 & 20 & $70-120$ & -- \\
\hline 23 & Monroe-Red Hill & SE-04,05 & A & 82 & 540 & $90-120$ & -- \\
\hline 24 & Joseph & SE-08 & $S$ & 63 & 120 & $90-150$ & -. \\
\hline 25 & Cove Fort & BE-02 & A & 150 & -- & $180-225$ & 370 \\
\hline 26 & Roosevelt & $\mathrm{BE}-05$ & A & 240 & -- & $260-290$ & 2,590 \\
\hline 27 & Thermo & BE- $-46,47$ & A & 90 & $40-70$ & $140-200$ & -. \\
\hline 28 & Wood's Ranch & IR-10 & W & 37 & -- & $110-120$ & 60 \\
\hline 29 & De Armand & IR-16 & W & 149 & 3,785 & -- & 3,750 \\
\hline 30 & Newcastle & IR-27 & A & 97 & -- & $140-170$ & 150 \\
\hline 31 & Veyo & WA-06 & $S$ & 30 & 390 & $40-60$ & -- \\
\hline 32 & Dixie, La Verkin & WA-08 & $S$ & 42 & 18,000 & $50-90$ & $\ldots$ \\
\hline 33 & Split Mntn. & UI-03 & $S$ & 30 & 10,200 & - & -- \\
\hline 34 & Ashley Valley & $\mathrm{UI}-21$ & W & 58 & - & -- & 1,710 \\
\hline
\end{tabular}


With few exceptions, the more important geothermal areas in Utah occur either in the Basin and Range Province or within the Transition Zone (figure 1). The most significant known occurrence of geothermal water in eastern Utah is from oil wells of the Ashley Valley oil field, which yield large volumes of nearly fresh water at temperatures between $43^{\circ} \mathrm{C}$ and $55^{\circ} \mathrm{C}\left(109^{\circ} \mathrm{F}\right.$ and $131^{\circ} \mathrm{F}$ ) as a byproduct of oil production. In 1981, the Ashley Valley field yielded 3,360 acre-feet (26.1 million barrels) of water (Goode, 1985).

In central and western Utah, most thermal areas are located in valleys near the margins of mountain blocks, and are thought to be controlled by active Basin and Range faults. Others occur in hydrologic discharge zones at the bottom of valleys. A few thermal areas are situated in mountainous regions.

Wright and others (1990) presented data, including estimated reservoir temperatures, on some Utah geothermal areas based on the work of Swanberg (1974), Cole (1983), and Rush (1983). These data are shown in table 1 along with information from eight additional lowtemperature areas. These areas are identified on figure 1.

Using geothermometry and other information, Rush (1983) suggested that six areas in Utah are probably high-temperature geothermal systems with reservoir temperatures above $150^{\circ} \mathrm{C}\left(302^{\circ} \mathrm{F}\right)$. He also suggested that ten other areas could be classified as moderatetemperature geothermal systems with reservoir temperatures between $90^{\circ} \mathrm{C}$ and $150^{\circ} \mathrm{C}\left(194^{\circ} \mathrm{F}\right.$ and $302^{\circ} \mathrm{F}$ ). Known high-temperature systems include the Roosevelt Hot Springs and Cove Fort - Sulphurdale Known Geothermal Resource Areas (KGRA). Other potential high-temperature systems are Thermo Hot Springs, Joseph Hot Springs, the Newcastle area, and the Monroe-Red Hill area.

Wright and others (1990) summarized the present knowledge of Utah's geothermal resources, and discussed how factors such as regional low energy costs contribute to the relative low growth of geothermal energy in the state. Presently, electric power is generated at the Roosevelt Hot Springs and Cove Fort - Sulphurdale KGRAs. The installed gross capacity for the two areas is about $33 \mathrm{MWe}$. Commercial greenhouses that use thermal water for space heat operate at Newcastle in Iron County, and at Crystal Hot Springs near Bluffdale in Salt Lake County. Ten resorts use geothermal water for the heating of swimming pools, for small spaceheating applications, and for therapeutic baths. One of the newer direct-use geothermal developments is a commercial SCUBA-diving and aquaculture facility near Grantsville in Tooele County.

\section{DATA SOURCES}

\section{Previous Geothermal Studies}

DOE, the USGS, the National Science Foundation (NSF), and the UGS have either funded or co-funded more than 40 geothermal-related projects in Utah over the past 20 years. Budding and Bugden (1986) compiled an annotated bibliography of all published sources for geothermal studies in Utah through 1984, in which they included a summary of the governmentfunded projects. They categorized the government projects as either statewide, regional, or local. While many of these studies involved mainly surface geological and geophysical surveys, 
a number of the projects included the gathering of geochemical and other data from wells and springs.

Basic data on geothermal waters in Utah are included in various government reports, journal papers, water resource databases, and so forth. As part of DOE's geothermal program, the UGS gathered and published detailed information for low-temperature waters throughout Utah. For northern Utah and the East Shore area of the Great Salt Lake, sources of data included Murphy and Gwynn (1979), de Vries (1982), Cole (1981, 1983) and Davis and Kolesar (1984). Well and spring data for the central Wasatch Front are included in Klauk and Davis (1984), Klauk and Prawl (1984), and Kohler (1979). In southwestern Utah, information was available for the Sevier thermal area (Mabey and Budding, 1987), the Escalante Desert (Klauk and Gourley, 1983; Ross and others, 1991, 1993; Blackett and Shubat, 1992), and the St. George Basin (Budding and Sommer, 1986).

The previous geothermal resource map of Utah (Utah Geological and Mineral Survey, 1980) lists general information (temperature, depth, flow rate, location, and TDS) on lowtemperature wells and springs. Many of the same sources used to compile the state resource map were also used in compiling the Utah portion of the USGS's file-GEOTHERM database. Bliss (1983) presented the "hard copy" version of GEOTHERM for Utah that included 643 records on roughly 350 wells and springs.

Information on high-temperature geothermal exploration and production wells in the Cove Fort - Sulphurdale and Roosevelt Hot Springs KGRAs was also documented in Union Oil Company (1978), Ash and others (1979), Capuano and Cole (1982), and Ross and others (1982).

\section{The USGS's WATSTORE Database}

An additional source of information was the USGS's on-line water information system known as the National Water Data Storage and Retrieval System, or WATSTORE. WATSTORE is composed of various files and databases containing continually-updated records on regularly monitored wells and springs in the United States. WATSTORE's Ground-Water Site Inventory Database includes site location, geohydrologic characteristics, well-construction history, and various field measurements including water temperature. WATSTORE's Water Quality File contains analyses of water samples describing chemical, physical, biological, and radio-chemical characteristics (ReMillard and others, 1992).

\section{DATABASE FORMAT}

\section{Data Entry and Record Checking}

The principal steps involved in compiling the database and resource maps are illustrated on figure 2. A database format was developed using commercial database-management software so that information could be input manually from published sources. The format comprised three general divisions including location information, descriptive information, and water chemistry. Data from published sources on wells and springs with temperatures of $20^{\circ} \mathrm{C}$ or greater were entered manually using the commercial software. These records were then checked 


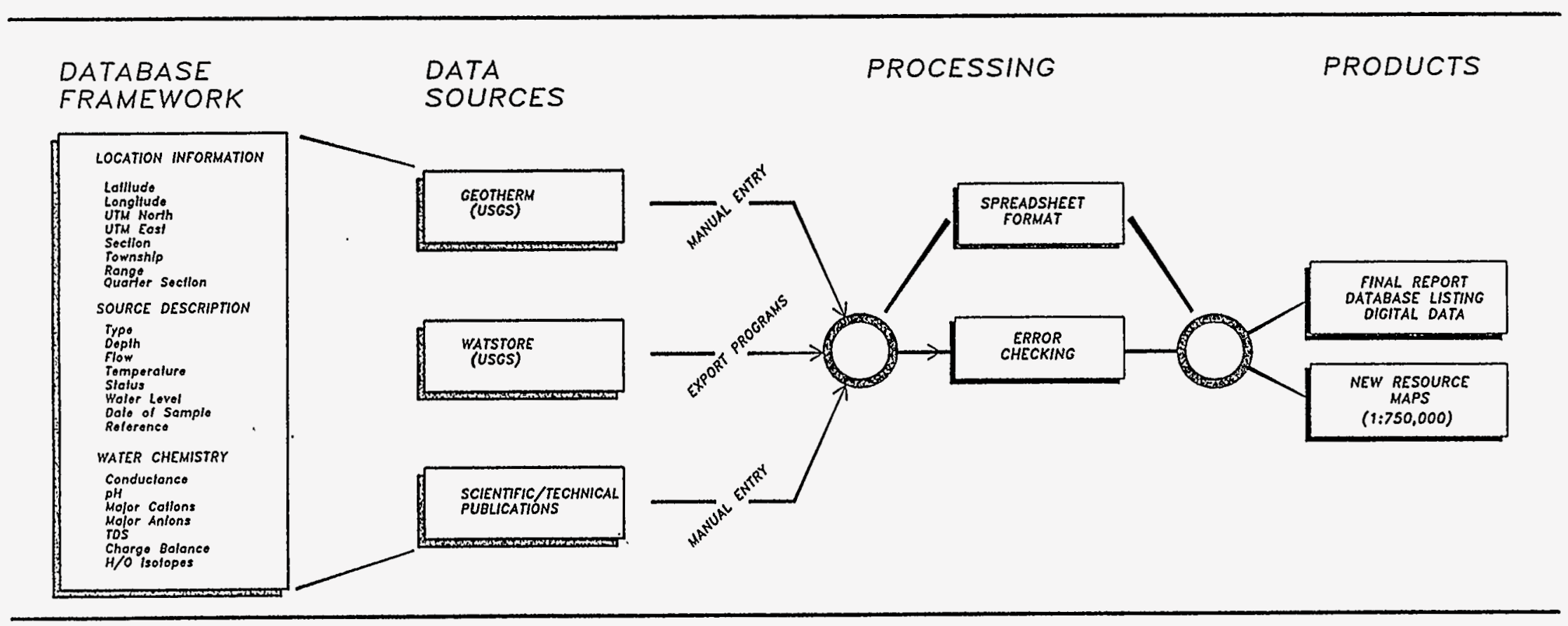

Figure 2. Flow chart showing the steps involved in compiling the geothermal database. 
against the original data for accuracy. Sorting routines were used to help identify duplicate records. After manually entering about 380 records, all of the data were then exported to a spreadsheet program for ease of editing and for combining with data from WATSTORE.

The regional office of the USGS Water Resources Division in Salt Lake City provided about 1,100 records from WATSTORE on wells and springs in Utah with temperatures of $20^{\circ} \mathrm{C}$ $\left(68^{\circ} \mathrm{F}\right)$ or greater. The digital data came in two ASCII-file formats. One file format listed lineby-line information from the Ground-Water Site Inventory Database, while the second file included water chemistry from the Water Quality File in an irregular, tabular format. Because neither file could be imported directly into a spreadsheet, they were modified using software for text-editing and programs written specifically to reformat the data. Because the water chemistry in WATSTORE often includes species not needed for geothermal studies (such as trace elements, radioisotopes, amino acids, and so forth), the applications extracted only those species most relevant. Subroutines in the applications checked for errors introduced during file editing and flagged problem records when errors were encountered. After importing the reformatted WATSTORE data into the main spreadsheet, redundant records were eliminated through various sorting routines.

Complete records from the database are listed in Appendices A and B. Appendix A contains location and descriptive information from the database organized by county. Appendix $\mathrm{B}$ contains the water chemistry from the database also organized by county. County codes are listed in table 2. The two listings are tied by the "Record ID" and "Map No." data fields.

Table 2: List of county codes used in map numbers.

\begin{tabular}{llll}
\hline & & & \\
BE & Beaver & PI & Piute \\
BO & Box Elder & RI & Rich \\
CA & Cache & SL & Salt Lake \\
CR & Carbon & SJ & San Juan \\
DG & Daggett & SE & Sevier \\
DA & Davis & SA & Sanpete \\
DU & Duchesne & SU & Summit \\
EM & Emery & TO & Tooele \\
GA & Garfield & UI & Uintah \\
GR & Grand & UT & Utah \\
IR & Iron & WS & Wasatch \\
JU & Juab & WA & Washington \\
KA & Kane & WY & Wayne \\
MI & Millard & WE & Weber \\
MO & Morgan & & \\
& & & \\
\hline
\end{tabular}




\section{Water Analyses Checking Procedure}

In order to help identify errors in data entry or possible problem analyses, programs were also written to calculate charge balance, compare measured TDS with calculated TDS, and check on relative concentrations of various dissolved species. A hierarchy (using the relative concentrations of dissolved species) suggested by M. J. Reed (U.S. Department of Energy, written communication, 1993) and listed below was used for checking analyses:

$$
\begin{gathered}
\mathrm{Na}>\mathrm{K}>\mathrm{Li} \\
\mathrm{Ca}>\mathrm{Mg}>\mathrm{Sr}>\mathrm{Ba} \\
\mathrm{Cl}>\mathrm{F}>\mathrm{Br}>\mathrm{I}
\end{gathered}
$$

Re-checking of the original data for accuracy was necessary whenever an analysis in the database failed to meet these conditions. Records that failed these checks for relative abundances of dissolved species are marked with an asterisk in Appendix B.

Ion concentrations for strontium, barium, bromide, and iodide were not usually reported in published sources, so they were not included in the database. Therefore, in the case of nonWATSTORE records, the ratios in the hierarchy involving only the major ions ( $\mathrm{Na}, \mathrm{K}, \mathrm{Ca}, \mathrm{Mg}$, $\mathrm{Cl}$, and $\mathrm{F}$ ) were checked. In ten of these non-WATSTORE records at least one of the ratios failed a condition of the hierarchy. Checking the original references against these data revealed that the values were entered as reported.

WATSTORE records were checked separately from those from published sources because the original data were digital, and because these data contained values for all of the species in the hierarchy. Checking of ratios revealed that, in 52 of the WATSTORE records, one or more ratios failed one of the conditions listed above. Re-checking of the data entries with the original digital data files revealed that all of the entries were made correctly.

\section{Descriptions of Final Products}

The distribution of geothermal sources plotted from the new database is very similar to that of the 1980 resource map (Utah Geological and Mineral Survey, 1980). The majority of thermal wells and springs are located along the eastern margin of the Basin and Range province or within the Transition Zone (figure 1, plates 1 and 2). Thermal wells and some springs occur in eastern and southeastern Utah, often where deep oil and gas wells have been converted to water supply sources. In general, however, temperature gradients in the Colorado Plateau and Rocky Mountain provinces are much less than those in the Basin and Range (Kron and Stix, 1982).

Because of the large number of records that needed to be presented, two resource maps were compiled. Plate 1 is a 1:750,000-scale map of the state showing the locations of all records and the ID numbers for those records with temperatures of $25^{\circ} \mathrm{C}\left(77^{\circ} \mathrm{F}\right)$ or more. Plate 2 shows the locations and ID numbers for those records with temperatures between $20^{\circ} \mathrm{C}$ and $25^{\circ} \mathrm{C}\left(68^{\circ} \mathrm{F}\right.$ and $\left.77^{\circ} \mathrm{F}\right)$.

The database is included with this report on DOS-formatted diskette under the file names UTAH.WQ1, UTLOC.DAT, and UTCHEM.DAT. Table 3 lists the data fields, descriptions 
Table 3. Utah geothermal database, data field summary.

FIELD NAME

RECORD ID
MAP NO.
SOURCE NAME
LOCATION
LATITUDE
LONGITUDE
UTM.NORTH
UTM.EAST

UTM.EAST

\section{FIELD CONTENTS}

LOCATION DATA

record ID number

county code plus number

owner or well/spring name

well and spring numbering

system for Utah

latitude north

longitude west

UTM north coordinate for zone 12

UTM east coordinate for zone 12 $\underline{\text { UNITS }}$

\begin{tabular}{|c|c|c|}
\hline DESIG & $\begin{array}{l}\text { designation from original reference } \\
\text { when applicable }\end{array}$ & NA \\
\hline TYPE & $\begin{array}{l}\text { well }(W) \text {, spring }(S) \\
\text { mine }(M), \text { collector }(C)\end{array}$ & NA \\
\hline TEMP & measured temperature & degrees Celsius \\
\hline DEPTH & depth of well & meters \\
\hline STA(TUS) & pumped $(\mathrm{P})$, flowing $(\mathrm{F})$ & NA \\
\hline FLOW & flow rate & liters per minute \\
\hline LEVEL & $\begin{array}{l}\text { depth to water level } \\
\text { (negative if above ground) }\end{array}$ & meters \\
\hline REFERENCE & short citation for source of data & NA \\
\hline DATE & date of sample (if available) & $\mathrm{mm} / \mathrm{dd} / \mathrm{yy}$ \\
\hline Conduct & conductivity & microseimens \\
\hline $\mathrm{pH}$ & $\mathrm{pH}$ & pH units \\
\hline $\mathrm{Na}$ & sodium & $\mathrm{mg} / \mathrm{L}$ \\
\hline $\mathrm{K}$ & potassium & $\mathrm{mg} / \mathrm{L}$ \\
\hline $\mathrm{Ca}$ & calcium & $\mathrm{mg} / \mathrm{L}$ \\
\hline $\mathrm{Mg}$ & magnesium & $\mathrm{mg} / \mathrm{L}$ \\
\hline $\mathrm{Al}$ & aluminum & $\mathrm{mg} / \mathrm{L}$ \\
\hline $\mathrm{Fe}$ & iron & $\mathrm{mg} / \mathrm{L}$ \\
\hline $\mathrm{SiO} 2$ & silica & $\mathrm{mg} / \mathrm{L}$ \\
\hline B & boron & $\mathrm{mg} / \mathrm{L}$ \\
\hline $\mathrm{Li}$ & lithium & $\mathrm{mg} / \mathrm{L}$ \\
\hline $\mathrm{HCO} 3$ & bicarbonate & $\mathrm{mg} / \mathrm{L}$ \\
\hline $\mathrm{SO} 4$ & sulfate & $\mathrm{mg} / \mathrm{L}$ \\
\hline $\mathrm{Cl}$ & chloride & $\mathrm{mg} / \mathrm{L}$ \\
\hline F & fluoride & $\mathrm{mg} / \mathrm{L}$ \\
\hline TDSm & total dissolved solids measured & $\mathrm{mg} / \mathrm{L}$ \\
\hline TDSc & total dissolved solids caiculated & $\mathrm{mg} / \mathrm{L}$ \\
\hline ChgBal & charge balance & (cations/anions) $\times 100$ \\
\hline$\delta \mathrm{D}$ & deuterium & permil \\
\hline$\delta 018$ & oxygen-18 & permil \\
\hline
\end{tabular}


of field contents, and units for numeric values. The file UTAH.WQ1 was constructed using Quattro ${ }^{\mathrm{TM}}$ Pro, a DOS-compatible spreadsheet software package, and contains the entire database consisting of 964 records for 792 well and spring locations with temperatures of $20^{\circ} \mathrm{C}$ or more. The UTAH.WQ1 file can be accessed through Quattro ${ }^{\mathrm{TM}}$ or similar spreadsheet software, such as Lotus ${ }^{\mathrm{TM}} 1-2-3$. The file UTLOC.DAT is a fixed-field ASCII file containing the record ID numbers, source name, latitude, longitude, UTM coordinates, cadastral locations, descriptive information (such as temperature, well depths, and flow rates), and references. The file UTCHEM.DAT is a fixed-field ASCII file containing the record ID numbers, source names, and chemical analyses.

Figure 3 illustrates the distribution of the number of wells and springs contained in the database for various temperature ranges. The general distribution exhibits an inverse exponential form typical of that seen in other geothermal assessments. Systems in the lower temperature ranges are much more abundant than those in the higher ranges.

\section{FLUID CHEMISTRY}

Samples from selected thermal springs and wells, not adequately represented by existing data, were gathered for analysis as part of this study. Chemical analyses were completed by UURI as part of the study. Geothermometer calculations, charge balances, and Piper plots were included as part of the analytical report. These data were also entered into the Utah geothermal database and are identified in the reference field of the database by the entry "This Study." The complete analyses for these samples are listed on table 4. A description follows for each of the seven selected thermal springs and well sites.

\section{Abraham (Baker, Crater) Hot Springs, Juab County}

The Crater Springs geothermal area surrounds a Quaternary eruptive center in the northern Sevier Desert known as Fumarole Butte. Early Pleistocene basalt flows (0.9 Ma) erupted from the vent area and formed a broad volcanic apron now known as Crater Bench. The Drum Mountains fault zone, a north-northeast trending zone of high-angle normal faults, offsets basalt flows along the west-central side of Crater Bench at Fumarole Butte. Warm vapor rises from several fissures in the vicinity of Fumarole Butte. Abraham Hot Springs (JU-15), also referred to in literature as "Crater Springs" or "Baker Hot Springs," issues $8 \mathrm{~km}(5 \mathrm{mi})$ to the east of Fumarole Butte along the east margin of the Crater Bench basalt flows. Mabey and Budding (1987) postulated that the vapor venting from Fumarole Butte and the thermal waters at Abraham Hot Springs are part of the same geothermal system.

Temperatures at Abraham range up to $87^{\circ} \mathrm{C}\left(189^{\circ} \mathrm{F}\right)$. Rush (1983) estimated total flow rates from about 40 spring orifices at between 90 and 140 liters per second $(1,427$ and 2,219 gallons per minute). The geologic structure controlling the system is unknown, and the reservoir temperature is uncertain. Samples of cold springs issuing from the same site were collected for analyses as part of this study in order to develop more accurate mixing models. Analyses of the cold water, however, revealed that this water is very similar in composition to that of the hot springs, and suggests that the cold springs are merely cooled hot water. (Analysis of the cold 


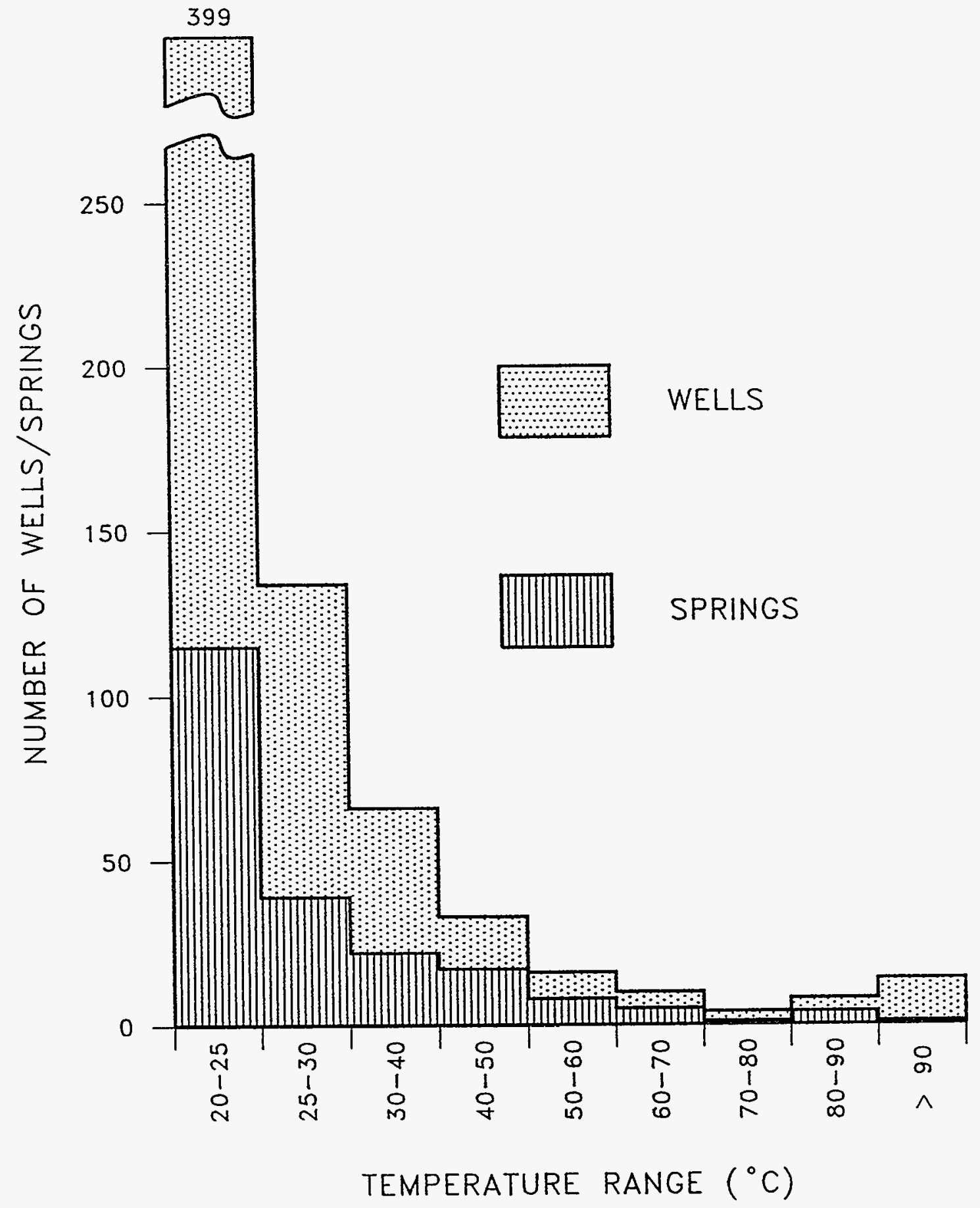

Figure 3. Histogram showing the numbers of wells and springs in various temperature ranges. 
le 4. Complete analyses of water samples gathered as part of this study.

\begin{tabular}{|c|c|c|c|c|c|c|}
\hline & units & & & & & \\
\hline ORD ID & & 327 & $\cdots-\infty \cdots$ & 433 & 439 & 719 \\
\hline No. & & $J U-15$ & -------- & $M I-80$ & $M I-82$ & TO-103 \\
\hline RCE NAME & & Abraham & Abraham (cold) & Meadow east & Meadow south & Blue Lake \\
\hline ATION & & (C-14-08) 10dca & $(\mathrm{C}-14-08) 10 \mathrm{dca}$ & $(\mathrm{C}-22-06) 26 \mathrm{ccc}$ & $(C-22-06) 34$ & $(c-04-19) 06 d c d$ \\
\hline ITUDE & degrees $N$ & 39.6133 & 39.6133 & 38.8647 & 38.8605 & 40.5020 \\
\hline GITUDE & degrees $W$ & 112.7283 & 112.7283 & 112.5019 & 112.5098 & 114.0380 \\
\hline .NORTH & meters & 4386483 & 4386483 & 4302627 & 4302175 & 4487701 \\
\hline .EAST & meters & 350811 & 350811 & 369694 & 369000 & 242560 \\
\hline DERATURE & ${ }^{\circ} \mathrm{C}$ & 84.0 & 19.5 & 41.0 & 34.0 & 27.5 \\
\hline $\mathbf{E}$ & dd-mmm-yy & 26-Jun-91 & 18-Mar-93 & 28-Aug-92 & 18-Sep-92 & 11-Jun-93 \\
\hline ductance & microsiemens & 5800 & 6350 & 7300 & 7500 & 11000 \\
\hline pH & pH units & 7.3 & 7.5 & 6.7 & 6.8 & 8.0 \\
\hline Na & $\mathrm{mg} / \mathrm{L}$ & 740 & 991 & 1058 & 1054 & 1698 \\
\hline K & $\mathrm{mg} / \mathrm{I}$ & 51.5 & 65.9 & 148.2 & 149.1 & 126.0 \\
\hline $\mathrm{Ca}$ & $\mathrm{mg} / \mathrm{L}$ & 410.8 & 373.8 & 468.4 & 467.8 & 190.0 \\
\hline $\mathrm{Mg}$ & $\mathrm{mg} / \mathrm{I}$ & 57.4 & 58.8 & 92.9 & 92.3 & 72.6 \\
\hline A] & $\mathrm{mg} / \mathrm{L}$ & ND & ND & ND & ND & ND \\
\hline Ee & $\mathrm{mg} / \mathrm{L}$ & ND & ND & 0.050 & ND & 0.030 \\
\hline $\mathrm{SiO}_{2}$ & $\mathrm{mg} / \mathrm{L}$ & 88.6 & 67.2 & 56.7 & 56.8 & 34.6 \\
\hline B & $\mathrm{mg} / \mathrm{L}$ & 1.41 & 1.22 & 5.48 & 5.46 & 1.02 \\
\hline Li & $\mathrm{mg} / \mathrm{L}$ & 1.17 & 1.09 & 3.56 & 3.61 & 1.58 \\
\hline$s x$ & $\mathrm{mg} / \mathrm{L}$ & 7.92 & 8.17 & 6.1 & 5.96 & 3.05 \\
\hline $\mathrm{Zn}$ & $\mathrm{mg} / \mathrm{L}$ & ND & ND & ND & ND & ND \\
\hline $\mathrm{Ba}$ & $\mathrm{mg} / \mathrm{L}$ & ND & 0.74 & ND & ND & 0.42 \\
\hline$M n$ & $\mathrm{mg} / \mathrm{L}$ & 0.25 & ND & ND & ND & ND \\
\hline $\mathrm{Sb}$ & $\mathrm{mg} / \mathrm{L}$ & ND & ND & ND & $\mathrm{ND}$ & ND \\
\hline $\mathrm{SO}_{4}$ & $\mathrm{mg} / \mathrm{L}$ & 710.0 & 820 & 1090.0 & 1090.0 & 278.0 \\
\hline Cl & $\mathrm{mg} / \mathrm{L}$ & 1470 & 1681 & 1803 & 1795 & 3063 \\
\hline $\mathbf{F}$ & $\mathrm{mg} / \mathrm{L}$ & 2.70 & 2.75 & 9.60 & 9.50 & 0.75 \\
\hline TDSm & $\mathrm{mg} / \mathrm{L}$ & 3670 & 4095 & 4967 & 4913 & 5693 \\
\hline TDSC & $\mathrm{mg} / \mathrm{L}$ & 3621 & 4146 & 4875 & 4869 & 5617 \\
\hline ChgBal & $(c / a)$ & 100 & 102 & 100 & 100 & 96 \\
\hline $\bar{\delta} D$ & permil & NA & NA & -124.0 & -122.0 & NA \\
\hline 5018 & permil & NA & $\mathrm{NA}$ & -17.2 & -17.0 & NA \\
\hline
\end{tabular}

\begin{tabular}{|c|c|c|c|c|c|}
\hline ORD ID & & 726 & 861 & 870 & 947 \\
\hline NUMBER & & T0-109 & UT- 70 & WA-07 & WS-02 \\
\hline RCE NAME & & Wilson & Third Water & Dixie & Mt. Spa \\
\hline ATION & & $(c-10-14) 33 \mathrm{cdc}$ & $(D-08-05) 25 d c d$ & $(\mathrm{C}-41-13) 25 \mathrm{cac}$ & $(D-03-04) 26 \mathrm{cca}$ \\
\hline 'ITUDE & degrees $N$ & 39.9064 & 40.0829 & 37.1900 & 40.5255 \\
\hline 'GITUDE & degrees $W$ & 113.4303 & 111.3177 & 113.2717 & 111.4680 \\
\hline l.NORTH & meters & 4419986 & 4436800 & 4118163 & 4485592 \\
\hline i.EAST & meters & 292251 & 472914 & 298361 & 460102 \\
\hline IPERATURE & ${ }^{\circ} \mathrm{C}$ & 51.0 & 55.5 & 41.4 & 38.0 \\
\hline 'E & & 11-Jun-93 & 30-Sep-93 & $07-$ Feb- 94 & 21-May-93 \\
\hline $\begin{array}{c}\text {,auctance } \\
\text { pH }\end{array}$ & $\begin{array}{l}\text { microsiemens } \\
\text { pH units }\end{array}$ & $\begin{array}{c}39200 \\
7.3\end{array}$ & $\begin{array}{ll}x & 1400 \\
& 7.1\end{array}$ & $\begin{array}{c}11000 \\
6.1\end{array}$ & $\begin{array}{l}1800 \\
6.7\end{array}$ \\
\hline $\mathrm{Na}$ & $\mathrm{mg} / \mathrm{I}$ & 7243 & 306 & 2130 & 107 \\
\hline $\mathbf{K}$ & $\mathrm{mg} / \mathrm{L}$ & 216.4 & 9.9 & 167.8 & 23.6 \\
\hline Ca & $\mathrm{mg} / \mathrm{L}$ & 855.7 & 17.3 & 760.1 & 284.2 \\
\hline Mg & $\mathrm{mg} / \mathrm{I}$ & 250.7 & 4.8 & 156.1 & 65.9 \\
\hline Al & $\mathrm{mg} / \mathrm{L}$ & ND & ND & ND & ND \\
\hline $\mathrm{Fe}$ & $\mathrm{mg} / \mathrm{I}$ & 0.140 & 0.080 & ND & ND \\
\hline $\mathrm{SiO}_{2}$ & $\mathrm{mg} / \mathrm{L}$ & 45.3 & 43.1 & 27.0 & 24.0 \\
\hline$B^{2}$ & $\mathrm{mg} / \mathrm{L}$ & 3.66 & 0.90 & 4.80 & 0.53 \\
\hline $\mathbf{L i}$ & $\mathrm{mg} / \mathrm{I}$ & 3.18 & 0.21 & 2.39 & 0.33 \\
\hline Sr & $\mathrm{mg} / \mathrm{L}$ & 14.56 & 0.79 & 10.12 & 3.14 \\
\hline $\mathrm{Zn}$ & $\mathrm{mg} / \mathrm{I}$ & ND & 0.19 & 0.11 & ND \\
\hline $\mathrm{Ba}$ & $\mathrm{mg} / \mathrm{L}$ & 0.92 & 0.52 & 0.36 & ND \\
\hline$M n$ & $\mathrm{mg} / \mathrm{I}$ & ND & ND & ND & ND \\
\hline $\mathrm{Sb}$ & $\mathrm{mg} / \mathrm{L}$ & 1.5 & ND & ND & ND \\
\hline $\mathrm{so}_{4}$ & $\mathrm{mg} / \mathrm{I}$ & 1389.0 & 46.0 & 1841.0 & 558.0 \\
\hline $\mathrm{Cl}$ & $\mathrm{mg} / \mathrm{L}$ & 12530 & 153 & 3195 & 111 \\
\hline E & $\mathrm{mg} / \mathrm{L}$ & 2.75 & 2.88 & 3.00 & 2.80 \\
\hline TDSm & $\mathrm{mg} / \mathrm{L}$ & 22740 & 928 & 9075 & 1525 \\
\hline TDSC & $\mathrm{mg} / \mathrm{L}$ & 22647 & 887 & 8907 & 1478 \\
\hline ChgBal. & $(c / a) \times 100$ & 100 & 96 & 100 & 101 \\
\hline$\delta \mathrm{D}$ & permil & NA & NA & $\mathrm{NA}$ & NA \\
\hline 5018 & permil & NA & NA & NA & NA \\
\hline
\end{tabular}

- Not Detected

- Not Analyzed 
spring water is listed on table 4, however, it is not included in the Utah geothermal database.) According to the classification of Back (1961), the thermal water is sodium calcium-chloride type. Geothermometers suggest equilibration temperatures in the range $87^{\circ} \mathrm{C}$ to $116^{\circ} \mathrm{C}\left(189^{\circ} \mathrm{F}\right.$ to $\left.241^{\circ} \mathrm{F}\right)$.

\section{Meadow and Hatton Hot Springs, Millard County}

Meadow and Hatton Hot Springs are located about $16 \mathrm{~km}$ (10 mi) southwest of Fillmore in the eastern Black Rock Desert. Hatton Hot Spring issues from the south end of a large, northeast-trending travertine mound at a temperature of $63^{\circ} \mathrm{C}\left(145^{\circ} \mathrm{F}\right)$. Meadow Hot Springs, comprising several thermal springs in a northeast alignment and located in a marshy area about $2 \mathrm{~km}(1.25 \mathrm{mi})$ northwest of the Hatton travertine mound, issue at temperatures up to $41^{\circ} \mathrm{C}$ $\left(106^{\circ} \mathrm{F}\right)$.

Two fluid samples from the Meadow Hot Springs area (MI-80 and MI-82) were collected for this study and described by Ross and others (1993) in conjunction with the results of selfpotential surveys completed in the area. The new chemical data show very different values for potassium, silica, and fluoride concentrations compared to previous data, suggesting temporal variations in spring chemistry. Standard geothermometers range between $205^{\circ} \mathrm{C}(\mathrm{Na}-\mathrm{K}-\mathrm{Ca})$ and $86^{\circ} \mathrm{C}$ (Na-K-Ca-Mg), with most likely equilibration temperatures around $108^{\circ} \mathrm{C}$ (quartz conductive). Based on the results of the new chemical analyses, the fluids appear to be highly evolved with a very complex thermal history (M.C. Adams, University of Utah Research Institute, verbal communication, 1993).

\section{The Mountain Spa Resort, Wasatch County}

Thermal springs in and around the community of Midway in Wasatch County issue from several widespread, coalescing travertine mounds covering an area of several square kilometers. Temperatures in these springs range from $38^{\circ} \mathrm{C}$ to $46^{\circ} \mathrm{C}\left(100^{\circ} \mathrm{F}\right.$ to $\left.115^{\circ} \mathrm{F}\right)$. Kohler (1979) suggested that thermal water at Midway is the result of deep circulation of meteoric water from recharge zones located to the north near Park City. Geothermometry from water analyses indicates that the maximum reservoir temperature is about $75^{\circ} \mathrm{C}\left(167^{\circ} \mathrm{F}\right)$. At the Mountain Spa Resort thermal water is used for heating a swimming pool and for therapeutic baths. Since Kohler's (1979) study, spring flows, temperatures, and water levels in wells at the Mountain Spa Resort have reportedly declined (Linda Pritchett, 1993, verbal communication). New analyses of thermal water, performed as part of this study, represent the only complete set of chemical data for the springs at the Mountain Spa (WS-02). The Homestead, a hotel and resort complex near Midway, uses thermal water in a therapeutic (Jacuzzi) bath.

\section{Blue Lake Spring and Bonneville Salt Flats, Tooele County}

Low-temperature thermal waters are present in the western part of the Great Salt Lake Desert as recorded in wells used for brine production and mineral extraction around the Bonneville Salt Flats, and as thermal springs at Blue Lake and Salt Spring. Turk (1973) presents data on 13 "deep brine wells" drilled to depths ranging from $326 \mathrm{~m}$ to $631 \mathrm{~m}(1,070 \mathrm{ft}$ to 2,070 
$\mathrm{ft})$. The highest temperature recorded was $88^{\circ} \mathrm{C}\left(190^{\circ} \mathrm{F}\right)$, measured in the drilling mud of one well designated DBW-3 while circulating at a depth of $499 \mathrm{~m}(1,637 \mathrm{ft})$. The brine produced from these deep wells contains from 120,000 to $130,000 \mathrm{mg} / \mathrm{L}$ total dissolved solids.

Blue Lake and Salt Spring, located in western Tooele County near the Utah-Nevada border, are small lakes fed by thermal springs. Although the temperature of the spring vents (located beneath Blue Lake) are not known, the temperature of Blue Lake is fairly constant at about $29^{\circ} \mathrm{C}\left(84^{\circ} \mathrm{F}\right)$. The area, which is controlled by the U.S. Bureau of Land Management, is valuable for the recreational opportunities offered in the form of year-round diving, and as a wildlife habitat. Because previously reported analyses were incomplete, an analysis of water from Blue Lake (TO-103) was obtained as part of this study. Applicable geothermometer temperatures range between $35^{\circ} \mathrm{C}$ and $88^{\circ} \mathrm{C}\left(95^{\circ} \mathrm{F}\right.$ and $\left.190^{\circ} \mathrm{F}\right)$.

\section{Wilson Health Springs, Tooele County}

Hot springs also issue in and along the margins of Snake Valley, Tule Valley, and Fish Springs Flat of western Utah. Wilson Health Springs (TO-109), the site of an abandoned resort of the same name at the north end of the Fish Springs Range, issues from small mounds at temperatures approaching $60^{\circ} \mathrm{C}\left(140^{\circ} \mathrm{F}\right)$, with flow rates varying up to $380 \mathrm{~L} / \mathrm{min}(100 \mathrm{gpm})$. Thermal fluids at Wilson, analyzed as part of this study, are moderately saline with total dissolved solids content slightly over $21,000 \mathrm{mg} / \mathrm{L}$. Chemical geothermometers suggest equilibration temperatures of less than $100^{\circ} \mathrm{C}\left(212^{\circ} \mathrm{F}\right)$. The Fish Springs National Wildlife Refuge lies along the northeast flank of the Fish Springs Range. These broad wetlands are fed by a number of springs with temperatures ranging between $20^{\circ} \mathrm{C}$ and $29^{\circ} \mathrm{C}\left(68^{\circ} \mathrm{F}\right.$ and $\left.84^{\circ} \mathrm{F}\right)$. Wilson Health Springs is the northernmost, and hottest, of a series of north-trending, warm springs.

\section{Dixie (La Verkin) Hot Springs, Washington County}

At the Pah Tempe Hot Springs Resort (WA-07), springs flow from a number of vents along the Virgin River, near where the river crosses the Hurricane fault at the mouth of Timpoweap Canyon. The Virgin River has eroded Timpoweap Canyon into a thick sequence of Permian carbonate rocks. The flows have been altered over the past decade possibly due to a combination of man-made and natural causes. In the mid-1980s, construction of a water pipeline for the Quail Creek (off-line storage) reservoir reportedly disrupted the discharge of existing hot springs and new springs emerged at lower levels along the nearby Virgin River (Ben Everitt, Utah Division of Water Resources, verbal communication, 1993). Flows to the original springs were restored after installation of a clay and cement seal in the construction area. In September of 1992 , a $5.8 \mathrm{M}_{\mathrm{L}}$ earthquake evidently contributed to another disruption of spring flows as discharge decreased and again new springs emerged at lower levels along the Virgin River (Ken Anderson, Pah Tempe Resort, verbal communication). Available analyses for Dixie Hot Springs, done prior to the earthquake, are variable and possibly reflect differences in sample collection points. A sample collected as part of this study was taken from one of the new spring orifices where the Quail Creek pipeline crosses the Virgin River. The new sample results show similar variability compared with the previous analyses. The water is sodium calcium-chloride, 
sulfate, bicarbonate type. Geothermometers suggest equilibration temperatures between $75^{\circ} \mathrm{C}$ and $80^{\circ} \mathrm{C}\left(167^{\circ} \mathrm{F}\right.$ and $\left.176^{\circ} \mathrm{F}\right)$.

\section{Third Water Hot Springs, Utah County}

Hot springs that are well known to hikers and mountain-bikers and referred to here as "Third Water Hot Springs" (UT-70), are located in the Uinta National Forest of eastern Utah County. Unusual because they occur at an elevation of $1,890 \mathrm{~m}(6,200 \mathrm{ft})$ in the Wasatch Mountains, the springs were known only to recreational enthusiasts and were not reported in previous geothermal or water-resource publications. Third Water Hot Springs issue from multiple vents along Third Water Creek, about three miles east of Three Forks Campground in Diamond Fork Canyon. Access to the springs is by hiking, mountain-biking, or on horseback. The springs occur over a distance of about 0.5 kilometer $(0.3 \mathrm{mi})$ in and along the stream

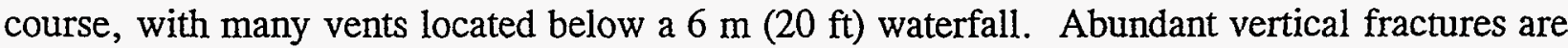
apparent with some evidence of offset. Bedrock consists mostly of pebble and cobble conglomerate, probably of upper Cretaceous (Price River Formation) or lower Tertiary (North Horn Formation) age.

Spring temperatures range from tepid to a maximum measured temperature of $55.5^{\circ} \mathrm{C}$ $\left(131.9^{\circ} \mathrm{F}\right)$ at a vent located just below the waterfall. The springs give off a pervasive sulfurous odor, and deposit both white and black mineral coatings on the stream bottom. A field pH of 7.03 was measured at the sampled vent, and analyses of a water sample yielded a total dissolved solids content of $932 \mathrm{mg} / \mathrm{L}$. Geothermometers suggest equilibration temperatures between $65^{\circ} \mathrm{C}$ and $97^{\circ} \mathrm{C}\left(149^{\circ} \mathrm{F}\right.$ and $\left.207^{\circ} \mathrm{F}\right)$. Results of the laboratory analysis, included in the database, indicate a sodium-bicarbonate, chloride, sulfate type water.

\section{RECOMMENDED FUTURE STUDY AREAS}

A list of geothermal areas in Utah recommended for additional resource investigations was developed as part of this project and forwarded to the Oregon Institute of Technology as recommended future study sites. The list, which includes seven areas, will be used in selecting sites for additional work under possible future phases of DOE's Low-temperature Geothermal Program. The list was developed on the basis of resource temperatures and flow rates; and on resource locations with respect to transportation systems, population centers, and agricultural regions.

\section{Newcastle Area, Iron County}

The Newcastle area, located near the south end of the Escalante Valley in Iron County, is underlain by an aquifer containing low- and moderate-temperature geothermal fluid. The area is experiencing expanded use of the geothermal aquifer with the construction of new commercial greenhouse facilities. Milgro Nurseries, a California-based company, has completed a (first of seven planned) four-acre greenhouse facility which houses 500,000 flowering plants for distribution to customers throughout the U.S. Couple this expansion with two other established 
commercial greenhouse operations and significant fluid and thermal withdrawals from the aquifer can be expected over the next several years. The UGS, UURI, and the University of Utah performed analyses of 27 thermal-gradient drill holes, geophysical surveys, and geologic mapping (Blackett and Shubat, 1992). Still lacking, however is a detailed hydrologic study, so the resource potential of the system is presently undetermined. In order to adequately protect the geothermal aquifer and ensure a continued supply of energy to commercial users, geohydrologic studies and modelling of fluid flow and heat transfer is needed. Additional, slimhole drilling is also needed to evaluate the center of the geothermal system.

The unincorporated town of Newcastle lies just north of the center of the geothermal system. An LDS chapel in the town is heated by the geothermal water. The system is located near state highway 56 which connects Cedar City, $48 \mathrm{~km}$ (30 mi) to the east, to a number of small communities in the Escalante Valley to the west. The Escalante Valley is an agricultural region that produces potatoes, alfalfa, corn, and livestock. Cedar City is situated along Interstate 15 , and is served by a Union Pacific rail-line and a scheduled-service airport.

A maximum temperature of $130^{\circ} \mathrm{C}\left(266^{\circ} \mathrm{F}\right)$ was measured in a geothermal exploration well which penetrated the geothermal aquifer (outflow plume). Production wells at the greenhouses generally produce fluids in the range of $75^{\circ} \mathrm{C}$ to $95^{\circ} \mathrm{C}\left(167^{\circ} \mathrm{F}\right.$ to $\left.203^{\circ} \mathrm{F}\right)$. Geothermometers suggest maximum resource temperatures of up to $166^{\circ} \mathrm{C}\left(331^{\circ} \mathrm{F}\right)$, with more likely temperatures of $140^{\circ}$ to $150^{\circ} \mathrm{C}\left(284^{\circ}\right.$ to $\left.302^{\circ} \mathrm{F}\right)$.

Geothermal production wells tap an unconfined, alluvial aquifer, which contains hot water and covers an area of several square miles. Thermal water originates from a buried point-source near a range-front fault, and spills into the aquifer. The fluids cool by conduction and probably mix with shallow groundwater at the system margins.

Land ownership is mostly private, although the subsurface source of the system projects beneath federal land. Geothermal users obtain "non-consumptive use" permits from the Utah Division of Water Rights (State Engineer) and return spent geothermal fluid to the aquifer via either injection wells or settling ponds. Because resource temperatures likely exceed $120^{\circ} \mathrm{C}$ $\left(248^{\circ} \mathrm{F}\right)$ in at least part of the system, production of fluids could be regulated by both federal and state agencies, and by private land-owners.

\section{Meadow-Hatton Area, Millard County}

The Meadow-Hatton geothermal area, described previously, consists of a large travertine mound, marshland, and thermal springs located about $10 \mathrm{~km}(7 \mathrm{mi})$ southwest of the town of Fillmore on the east side of the Black Rock Desert. The Black Rock Desert contains some of the state's youngest volcanic rocks -- some being only a few hundred years old. Virtually no comprehensive geothermal assessment has been performed in the area. Recent self-potential surveys performed by UURI and the UGS revealed a high-amplitude, negative anomaly beneath the southern part of the travertine mound.

The Meadow-Hatton area is located less than $2 \mathrm{~km}(1.3 \mathrm{mi})$ west of Interstate 15 in Millard County. Fillmore, the county seat with a population of 2,000 people, is located about $10 \mathrm{~km}(7 \mathrm{mi})$ to the northeast. The small community of Meadow (population 250) is situated on Interstate 15 , less than $2 \mathrm{~km}(1.3 \mathrm{mi})$ from the thermal area. The Pavant Valley and the 
Black Rock Desert comprise mostly irrigated croplands. Land ownership in the Pavant Valley and Black Rock Desert is a combination of private, state, and federal parcels.

Spring temperatures range between $30^{\circ}$ and $63^{\circ} \mathrm{C}\left(86^{\circ}\right.$ and $\left.145^{\circ} \mathrm{F}\right)$. Geothermometers suggest resource temperatures in the range $85^{\circ}$ to $114^{\circ} \mathrm{C}\left(185^{\circ}\right.$ to $\left.237^{\circ} \mathrm{F}\right)$. Flow rates from the springs are low and reportedly vary from 0 to 4 liters $/ \mathrm{sec}$ ( 0 to 60 gallons $/ \mathrm{min})$. The spring waters are probably coupled to the regional ground-water flow system of the Pavant Valley and Black Rock Desert.

\section{Midway Area, Wasatch County}

Midway is a small farming and resort town located about $8 \mathrm{~km}(5 \mathrm{mi})$ west of Heber City in Wasatch County. Thermal water here has been used in pools and spas for several decades. Because the area is growing rapidly, many new residences are beginning to use the geothermal water for space-heating. A DOE-funded study in 1979 showed that the geothermal system extends for several square miles around Midway.

Midway's population was 1,554 during the 1990 Census, an increase of 30 percent over the 1980 Census. U.S. Highways 189 and 40 connect Midway with the larger, nearby communities of Provo, Heber, and Park City. The Heber Valley is an agricultural area producing alfalfa, corn, and cattle.

Maximum measured temperature is about $45^{\circ} \mathrm{C}\left(113^{\circ} \mathrm{F}\right)$. Geothermometers suggest equilibration temperatures around $70^{\circ} \mathrm{C}\left(158^{\circ} \mathrm{F}\right)$. Thermal water is contained within fractured, Paleozoic quartzite in a broad antiform structure. Leakage to the surface is expressed as scattered thermal springs and widespread travertine deposits (Kohler, 1979).

Drawdown of the resource has been observed, and water rights of established users may be compromised as development of the resource continues. Additional work is needed to define the hydrologic controls on the system, and to provide a technical basis for addressing conflicts regarding rights to the thermal water.

\section{Wood's Ranch, Iron County}

Wood's Ranch, bearing the name of its owner, Mr. Lehi Wood, is located just south of the Wah Wah Mountains in the northwest part of the Escalante Valley in Iron County. One of the two thermal wells, a $61 \mathrm{~m}(200 \mathrm{ft})$ deep water well produces $36.5^{\circ} \mathrm{C}\left(97.7^{\circ} \mathrm{F}\right)$ water. No hot springs are present. A self-potential survey performed by UURI and the UGS revealed a broad, negative SP anomaly interpreted as thermal up-flow. Beyond the SP survey and water analysis performed by UURI and the UGS, no exploration has been carried out on the property.

The area is somewhat remote with no incorporated communities nearby. The Union Pacific rail line connecting Las Vegas with Salt Lake City, crosses the Escalante Valley within 1 mile of Wood's Ranch. Access roads into the area are both improved county and BLM roads, and jeep trails. Land ownership in the vicinity of the thermal wells is private. Surrounding lands are federal and state owned.

Geothermometers suggest equilibration temperatures in the range of $100^{\circ}$ to $115^{\circ} \mathrm{C}\left(212^{\circ}\right.$ to $239^{\circ} \mathrm{C}$ ). The warm water produced from the well may be a mixture of thermal water and 
normal ground-water from the Escalante Valley aquifer. Thermal gradient drilling and hydrologic testing is needed to determine resource potential.

\section{Thermo Hot Springs, Beaver County}

The Thermo Hot Springs geothermal area is located in the northeastern extension of the Escalante Valley in Beaver County. Surface expression consists of two large north-south oriented spring mounds. Companies in the past have performed geothermal exploration activities including geophysics, geochemistry, and exploratory drilling. Geologic maps of the area are available through the U.S. Geological Survey. Recent work by UURI and the UGS has revealed a high-amplitude, self-potential anomaly southeast of the hot springs.

The area is somewhat remote with the nearest community (Minersville) situated about 24 $\mathrm{km}(15 \mathrm{mi})$ to the east. Improved BLM and rural county roads provide vehicle access. A Union Pacific rail line, which crosses the Escalante Valley connecting Salt Lake City with Las Vegas, is less than one mile to the west. Land in the northern Escalante Valley is primarily under federal ownership with some large state-owned parcels. Large agricultural areas exist near Minersville to the east, and around Milford to the north.

Spring discharge temperatures range upward to $89.5^{\circ} \mathrm{C}\left(193^{\circ} \mathrm{F}\right)$. Discharge from the springs, observed in 1991, is small, varying from 0.5 to $2 \mathrm{~L} / \mathrm{s}$ ( 8 to 32 gallons $/ \mathrm{min}$ ). The spring system is probably coupled with the regional ground-water flow of the Escalante Valley. A deep exploratory drill hole encountered a maximum temperature of $174^{\circ} \mathrm{C}\left(345^{\circ} \mathrm{F}\right)$ at $2,000 \mathrm{~m}(6,562$ ft) (Republic Geothermal, unpublished data). Geothermometers suggest that the equilibration temperatures of the spring waters range from $120^{\circ} \mathrm{C}$ to $140^{\circ} \mathrm{C}\left(248^{\circ} \mathrm{F}\right.$ to $\left.284^{\circ} \mathrm{F}\right)$.

\section{Monroe Area, Sevier County}

Monroe is a small community located about $5 \mathrm{~km}(3 \mathrm{mi})$ miles east of Interstate 70 in Sevier County. It was the site of a number of studies that included geoscience and exploratory drilling sponsored by the U.S. Department of Energy in the late 1970's and early 1980's to assess resource potential (Mabey and Budding, 1987). Although feasibility studies based upon fluid temperatures and flow-rates from a DOE-sponsored production well showed that a districtheating system was not economical, the area could be attractive for process or agricultural direct-heat applications. A re-evaluation of the Monroe area focussing on the hydrology of the system is needed.

Monroe Hot Springs and Red Hill Hot Springs are situated less than 0.5 mile east of the town of Monroe, a community of about 1,470 people. Richfield (population - 5,590), the county seat of Sevier County is located a few miles to the north along Interstate 70. The Sevier-Sanpete Valley is an agricultural region extending for about 80 miles northeastward from the Monroe area. Land ownership in the Sevier Valley is mostly private.

Geothermometers suggest equilibration temperatures of about $110^{\circ} \mathrm{C}\left(230^{\circ} \mathrm{F}\right)$. Maximum measured temperature is $77^{\circ} \mathrm{C}\left(171^{\circ} \mathrm{F}\right)$ at Red Hill Hot Springs and $76^{\circ} \mathrm{C}\left(169^{\circ} \mathrm{C}\right)$ at Monroe Hot Springs. Combined flows for the Monroe-Red Hill system have been estimated at about 20 liters/sec (317 gallons/min.). 


\section{Crystal Hot Springs Area, Salt Lake County}

Crystal Hot Springs is situated at the southern end of the Jordan Valley in Salt Lake County. Utah Roses, Inc., a commercial greenhouse operator, and the Utah State Prison use thermal water from wells for space-heating. The area is located just west of Interstate 15 near the town of Bluffdale. Bluffdale, a town of 2,150 people, about $30 \mathrm{~km}$ (20 mi) south of Salt Lake City, experienced a 65 percent increase in population during the $1980 \mathrm{~s}$. This trend continues in the southern Jordan Valley. Rail lines of the Union Pacific Railroad and the Denver and Rio Grande Western Railroad pass through Bluffdale. Land ownership in the Jordan Valley is mostly private.

Surface spring temperatures are about $62^{\circ} \mathrm{C}\left(144^{\circ} \mathrm{F}\right)$, and Utah Roses reports subsurface temperatures of $88+{ }^{\circ} \mathrm{C}\left(190+^{\circ} \mathrm{F}\right)$ in one of their $122 \mathrm{~m}(400 \mathrm{ft})$ deep production well. Quartz geothermometers indicate reservoir temperatures possibly up to $115^{\circ} \mathrm{C}\left(239^{\circ} \mathrm{F}\right)$. The springs issue from valley alluvium into several ponds. When one of Utah Roses' production well is in operation, the surface springs and ponds reportedly dry up. Wright and others (1990) also report hydraulic interference between production wells of Utah Roses and the State Prison.

\section{SUMMARY}

The 1993 geothermal database for Utah contains data from most of the sources used in the USGS's File-GEOTHERM (Bliss, 1983) plus much new data from other sources that, combined, more than doubles the number of wells and springs previously listed in GEOTHERM. The database is comprehensive and personal-computer oriented to provide users with ready access to detailed geothermal information in Utah. Included in this report are both hard-copy and digital versions of the data (964 records on 792 source locations).

The general goal, as outlined in the contract Statement of Work, was to provide digital data in a spreadsheet format along with a final report and accompanying resource maps. Precautions were taken to minimize errors due to data input or editing and to eliminate poorquality records. However, errors and erroneous data undoubtedly exist. The database should include all non-proprietary geothermal information available through 1992, however, some references may have been overlooked during the compilation.

By and large, geothermal sources in the database include only those that have in the past or currently produce water. For instance, deep oil and gas wells, and thermal-gradient boreholes do not appear in the database. One exception to this rule is the case of oil and gas wells, mostly in Uinta Basin and southeastern Utah, that have been converted to water wells. Information from deep exploratory wells and temperature-gradient holes will hopefully be included in later versions of the database.

\section{ACKNOWLEDGMENTS}

Howard Ross of UURI, and Paul Lienau and Gene Culver of OIT provided valuable comments and suggestions regarding the scope of the overall work. Dave Allen and Briant 
Kimball of the USGS/WRD provided well and spring information from the U.S. Geological Survey's WATSTORE database and made suggestions for solving various problems related to water chemistry data in WATSTORE. Marshall Reed of the U.S. Department of Energy, Geothermal Division provided culled information from the U.S. Geological Survey's GEOTHERM database, and suggested a hierarchy for checking the validity of the water chemistry data. Charles Bishop of the Utah Geological Survey helped prepare the preliminary resource maps. Bryce Tripp and Bob Gloyn of the Utah Geological Survey reviewed all or parts of the manuscript and provided many helpful comments and suggestions. 


\section{REFERENCES}

Ash, D.L., Dondanville, R.F., and Gulati, M.S., 1979, Geothermal reservoir assessment, Cove Fort-Sulphurdale unit; final report for the period September, 1977 - July, 1979: U.S. Department of Energy Report DOE/ET/28405-1, 34 p.

Back, William, 1961, Techniques for mapping hydrochemical facies: U.S. Geological Survey Professional Paper 424-D, p. 380-382.

Budding, K.E., and Bugden, M.H., 1986, Annotated geothermal bibliography of Utah: Utah Geological and Mineral Survey Bulletin 121, 82 p.

Budding, K.E., and Sommer, S.N., 1986, Low-temperature geothermal assessment of the Santa Clara and Virgin River Valleys, Washington County, Utah: Utah Geological and Mineral Survey Special Study 67, 34 p.

Blackett, R.E., and Shubat, M.A., 1992, A case study of the Newcastle geothermal system, Iron County, Utah: Utah Geological Survey Special Study 81, 30 p.

Bliss, J.D., 1983, Utah - basic data for thermal springs and wells as recorded in GEOTHERM: U.S. Geological Survey Open-File Report 83-437, 380 p.

Bliss, J.D., and Rapport, Amy, 1983, GEOTHERM - the U.S. Geological Survey geothermal information system: Computers \& Geosciences, v. 9, no. 1, p. 35-39.

Capuano, R.M., and Cole, D.R., 1982, Fluid-mineral equilibria in a hydrothermal system, Roosevelt Hot Springs, Utah: Geochimica et Cosmochimica Acta, v. 46, no. 8, p. 13531364.

Chapman, D.S., Blackwell, D.D., Parry, W.T., Sill, W.R., Ward, S.H., and Whelan, J.A., 1978, Regional heat flow and geochemical studies in southwest Utah: University of Utah, Department of Geology and Geophysics Final Report, v. 2, contract no. 14-08-0001-G$341,118 \mathrm{p}$.

Chapman, D.S., Clement, M.D., and Mase, C.W., 1981, Thermal regime of the Escalante Desert, Utah, with an analysis of the Newcastle geothermal system: Journal of Geophysical Research, v. 86, no. B12, p. 11,735-11,746.

Cole, D.R., 1981, Isotopic and ion chemistry of waters in the east shore area, northern Utah: Geothermal Resources Council, Transactions, v. 6, p. 81-84.

Cole, D.R., 1983, Chemical and isotopic investigation of warm springs associated with normal faults in Utah: Journal of Volcanology and Geothermal Research, v. 16, pp. 65-98. 
Davis, M.C., and Kolesar, P.T., 1984, Evaluation of low-temperature geothermal potential in north-central Box Elder County, Utah: Utah Geological and Mineral Survey Report of Investigation 192, $92 \mathrm{p}$.

de Vries, J.L., 1982, Evaluation of low-temperature geothermal potential in Cache Valley, Utah: Utah Geological and Mineral Survey Report of Investigation 174, 96 p.

Fenneman, N.M., 1931, Physiography of the western United States: McGraw-Hill Book Company, New York, 534 p.

Goode, H.D., 1978, Thermal waters of Utah: Utah Geological and Mineral Survey Report of Investigation $129,183 \mathrm{p}$.

Goode, H.D., 1985, Hot water from the Ashley Valley oil field, in Guidebook to Geology and Energy Resources of the Uinta Basin, Picard, M.D., editor, Utah Geological Association Publication 12, p. 295-299.

Hintze, L.F., 1988, Geologic history of Utah: Brigham Young University Geology Studies, Special Publication 7, 202 p.

Klauk, R.H., and Davis, D.A., 1984, Evaluation of low-temperature geothermal potential in Utah and Goshen Valleys and adjacent areas, Utah County, Utah, Part II - water temperature and chemistry: Utah Geological and Mineral Survey Report of Investigation $191,45 \mathrm{p}$.

Klauk, R.H., and Gourley, Chad, 1983, Geothermal assessment of a portion of the Escalante Valley, Utah: Utah Geological and Mineral Survey Special Study 63, 57 p.

Klauk, R.H., and Prawl, C.A., 1984, Geothermal assessment of part of the East Shore area, Davis and Weber Counties, Utah: Utah Geological and Mineral Survey Report of Investigation $183,46 \mathrm{p}$.

Kohler, J.F., 1979, Geology, characteristics, and resource potential of the low-temperature geothermal system near Midway, Wasatch County, Utah: Utah Geological and Mineral Survey Report of Investigation 142, $64 \mathrm{p}$.

Kron, Andrea, and Stix, John, 1982, Geothermal gradient map of the United States exclusive of Alaska and Hawaii: National Geophysical Data Center, National Oceanic and Atmospheric Administration, scale 1:2,500,000.

Mabey, D.R., and Budding, K.E., 1987, High-temperature geothermal resources of Utah: Utah Geological and Mineral Survey Bulletin 123, 64 p. 
Muffler, L.J.P., editor, 1979, Assessment of geothermal resources of the United States -- 1978: U.S. Geological Survey Circular 790, 163 p.

Murphy, P.J., and Gwynn, J.W., 1979, Geothermal investigations at selected thermal systems of the northern Wasatch Front, Weber and Box Elder Counties, Utah: Utah Geological and Mineral Survey Report of Investigation 141, $50 \mathrm{p}$.

Reed, M.J., editor, 1983, Assessment of low-temperature geothermal resources of the United States -- 1982: U.S. Geological Survey Circular 892, 73 p.

ReMillard, M.D., Herbert, L.R., Birdwell, G.A., and Lockner, T.K., 1992, Water resources data - Utah water year 1991: U.S. Geological Survey Water-Data Report UT-91-1, 375 p.

Ross, H.P., Blackett, R.E., and Shubat, M.A., 1991, Wood Ranch thermal anomaly: Utah Geological Survey Miscellaneous Publication 91-4, 21 p.

Ross, H.P., Blackett, R.E., Shubat, M.A., and Gloyn, R.W., 1993, Self-potential and fluid chemistry studies of the Meadow-Hatton and Abraham Hot Springs, Utah: Geothermal Resource Council Transactions, v. 17, p. 167-174.

Ross, H.P., Nielson, D.L., and Moore, J.N., 1982, Roosevelt Hot Springs geothermal system, Utah - case study: American Association of Petroleum Geologists Bulletin, v. 66, no. 7, p. 879-902.

Rush, E.F., 1983, Reconnaissance of the hydrothermal resources of Utah: U.S. Geological Survey Professional Paper 1044-H, $44 \mathrm{p}$.

Sass, J.H., and Munroe, R.J., 1974, Basic heat-flow data from the United States: U.S. Geological Survey Open-File Report 76-756, 24 p.

Sass, J.H., Diment, W.H., Lachenbruch, A.H., Marshall, B.V., Munroe, R.J., Moses, T.H., Jr., and Utban, T.C., 1976, A new heat-flow contour map of the conterminous United States: U.S. Geological Survey Open-File Report 76-756, 24 p.

Stewart, J.H., Moore, W.J., and Zietz, Isidore, 1977, East-west patterns of Cenozoic igneous rocks, aeromagnetic anomalies, and mineral deposits, Nevada and Utah: Geological Society of America Bulletin, v. 88 , no. 1, p. 67-77.

Swanberg, C.A., 1974, The application of the Na-K-Ca geothermometer to thermal areas of Utah and the Imperial Valley, California: Geothermics, v. 3, no. 2, p. 53-59

Turk, L.J., 1973, Hydrogeology of the Bonneville Salt Flats, Utah: Utah Geological and Mineral Survey Water Resources Bulletin no. 19, 81 p. 
Union Oil Company, 1978, Geologic report of the Cove Fort-Sulphurdale geothermal unit area, Millard and Beaver Counties, Utah: Earth Science Laboratory/University of Utah Research Institute Open-File Report UT/CFS/UOC-1.2, 33 p.

Utah Geological and Mineral Survey, compilers, 1980, Geothermal resources of Utah, 1980: Map prepared by the National Oceanic and Atmospheric Administration for the U.S. Department of Energy, scale 1:500,000.

Williams, D.L., and Von Herzen, R.P., 1974, Heat loss from the earth: new estimate: Geology, v. 2 , p. $327-328$.

Wright, P.M., Blackett, R.E., and Ross, H.P., 1990, Geothermal resource development in Utah: Utah Geological Association Publication 18, p. 27-43. 


\section{BIBLIOGRAPHY}

Ash, D.L., Dondanville, R.F., and Gulati, M.S., 1979, Geothermal reservoir assessment, Cove Fort-Sulphurdale unit; final report for the period September, 1977 - July, 1979: U.S. Department of Energy Report DOE/ET/28405-1, 34 p.

Baker, C.H., Jr., 1970, Water resources of the Heber-Kamas-Park City area, north central Utah: Utah Department of Natural Resources Technical Publication no. 27, 79 p.

Baker, C.H., Jr., 1974, Water resources of the Curlew Valley drainage basin, Utah and Idaho: Utah Department of Natural Resources Technical Publication no. 45, 91 p.

Becker, D.J. and Blackwell, David, 1993, Gravity and hydrothermal modeling of the Roosevelt Hot Springs area, southwestern Utah: Journal of Geophysical Research, v. 98, no. B10, p. $17,787-17,800$.

Bjorklund, L.J., 1967, Ground-water resources of northern Juab valley, Utah: Utah Department of Natural Resources Technical Publication no. 17, 69 p.

Bjorklund, L.J., and McGreevy, L.J., 1973, Selected hydrologic data, lower Bear River drainage basin, Box Elder County, Utah: U.S. Geological Survey, Utah Basic-Data Release no. 23,22 p.

Bjorklund, L.J., and McGreevy, L.J., 1974, Ground-water resources of the lower Bear River drainage basin, Box Elder County, Utah: Utah Department of Natural Resources Technical Publication no. 44.

Bjorklund, L.J., Sumsion, C.T., and Sandberg, G.W., 1977, Selected hydrologic data, Parowan Valley and Cedar City Valley drainage basin, Iron County, Utah: U.S. Geological Survey Utah Basic-Data Release no. 28, 55 p.

Blackett, R.E., Shubat, M.A. Chapman, D.S., Forster, C.B., Schlinger, C.M., and Bishop, C.E., 1990, The Newcastle geothermal system, Iron County, Utah: Utah Geological Survey Open-File Report no. 189, 179 p.

Blackett, R.E., and Shubat, M.A., 1992, A case study of the Newcastle geothermal system, Iron County, Utah: Utah Geological Survey Special Study 81, 30 p.

Bliss, J.D., 1983, Utah - basic data for thermal springs and wells as recorded in GEOTHERM: U.S. Geological Survey Open-File Report 83-437, 380 p.

Bliss, J.D., and Rapport, Amy, 1983, GEOTHERM - the U.S. Geological Survey geothermal information system: Computers \& Geosciences, v. 9, no. 1, p. 35-39. 
Bolke, E.L., and Price, Don, 1972, Hydrologic reconnaissance of the Blue Creek Valley area, Box Elder County, Utah: Utah Department of Natural Resources Technical Publication no. $37,38 \mathrm{p}$.

Bolke, E.L., and Waddell, K.M., 1972, Ground-water conditions in the East Shore area, Box Elder, Davis, and Weber Counties, Utah, 1960-1969: Utah Department of Natural Resources Technical Publication no. 35, 59 p.

Bolke, E.L., and Waddell, K.M., 1972B, Water quality data for the Flaming Gorge Reservoir area, Utah and Wyoming, 1969-1972: U.S. Geological Survey, Utah Basic-Data Release no., $24,50 \mathrm{p}$.

Budding, K.E., and Bugden, M.H., 1986, Annotated geothermal bibliography of Utah: Utah Geological and Mineral Survey Bulletin 121, 82 p.

Budding, K.E., and Sommer, S.N., 1986, Low-temperature geothermal assessment of the Santa Clara and Virgin River Valleys, Washington County, Utah: Utah Geological and Mineral Survey Special Study 67, 34 p.

Capuano, R.M., and Cole, D.R., 1982, Fluid-mineral equilibria in a hydrothermal system, Roosevelt Hot Springs, Utah: Geochimica et Cosmochimica Acta, v. 46, no. 8, p. 13531364.

Carpenter, C.H., Robinson, G.B., and Bjorklund, L.J., 1964, Selected hydrologic data, upper Sevier River basin, Utah: U.S. Geological Survey, Utah Basic-Data Report no. 8, 29 p.

Carpenter, C.H., and Young, R.A., 1963, Ground-water data, central Sevier Valley, parts of Sanpete, Sevier, and Piute Counties, Utah: U.S. Geological Survey, Utah Basic-Data Report no. 3, 34 p.

Chapman, D.S., Blackwell, D.D., Parry, W.T., Sill, W.R., Ward, S.H., and Whelan, J.A., 1978, Regional heat flow and geochemical studies in southwest Utah: University of Utah, Department of Geology and Geophysics Final Report, v. 2, contract no. 14-08-0001-G$341,118 \mathrm{p}$.

Chapman, D.S., Clement, M.D., and Mase, C.W., 1981, Thermal regime of the Escalante Desert, Utah, with an analysis of the Newcastle geothermal system: Journal of Geophysical Research, v. 86, no. B12, p. 11,735-11,746.

Cole, D.R., 1983, Chemical and isotopic investigation of warm springs associated with normal faults in Utah: Journal of Volcanology and Geothermal Research, v. 16, pp. 65-98. 
Conroy, L.S., and Fields, F.K., 1977, Climatologic and hydrologic data, southeastern Uinta Basin, Utah and Colorado, Water Years 1975 and 1976: U.S. Geological Survey, Utah Basic-Data Release No. 29, 244 p.

Cordova, R.M., 1969, Selected hydrologic data in southern Utah and Goshen Valleys, Utah: Utah Department of Natural Resources Basic Data Release no. 16, 35 p.

Cordova, R.M., Sandberg, G.W., and McConkie, Wilson, 1972, Ground-water conditions in the central Virgin River basin, Utah: Utah Department of Natural Resources Technical Publication no. $40,64 \mathrm{p}$.

Cosner, S.R., and Apps, J.A., 1978, Compilation of data on fluids from geothermal resources in the United States: University of California at Berkeley, Lawrence Berkeley Laboratory Report 5936, 108 p.

Davis, M.C., and Kolesar, P.T., 1984, Evaluation of low-temperature geothermal potential in north-central Box Elder County, Utah: Utah Geological and Mineral Survey Report of Investigation 192, $92 \mathrm{p}$.

de Vries, J.L., 1982, Evaluation of low-temperature geothermal potential in Cache Valley, Utah: Utah Geological and Mineral Survey Report of Investigation 174, 96 p.

Dennis, P.E., Maxey, G.B., and Thomas, H.E., 1946, Ground water in Pahvant Valley, Millard County, Utah: Utah Department of Natural Resources Technical Publication no. $3,96 \mathrm{p}$.

Doyuran, Vedat, 1972, Geology and ground-water resources of Ogden Valley, Utah: University of Utah, Department of Geology and Geophysics, Ph. D. thesis, 135 p.

Fairbanks, P.E., 1982, Chemical changes in ground water of northern Utah Valley, Utah: Logan, Utah State University, M.S. thesis, 92 p.

Feltis, R.D., 1966, Water from bedrock in the Colorado Plateau of Utah: Utah Department of Natural Resources Technical Publication no. 15, 79 p.

Feltis, R.D., 1967, Ground-water conditions in Cedar Valley, Utah: Utah Department of Natural Resources Technical Publication no. 16, 31 p.

Feth, J.H., Barker, D.A., Moore, L.G., Brown, R.J., and Veirs, C.E., 1966, Lake Bonneville, Hydrology of the Weber Delta District, including Ogden, Utah: U.S. Geological Survey Professional Paper 518, $76 \mathrm{p}$.

Gates, J.S., 1963, Selected hydrologic data, Tooele Valley, Tooele County, Utah: U.S. Geological Survey, Utah basic-data report no. 7, 23 p. 
Goode, H.D., 1978, Thermal waters of Utah: Utah Geological and Mineral Survey Report of Investigation 129, $183 \mathrm{p}$.

Goode, H.D., and Feltis, R.D., 1962, Water production from oil wells of the Uinta Basin, Uintah and Duchesne Counties, Utah: Utah Water Resources Bulletin no. 1, 32 p.

Hely, A.G., Mower, R.W., and Horr, C.A., 1967, Hydrologic and climatologic data, 1966, Salt Lake County, Utah: Utah Basic-Data Release no. 13, 85 p.

Hely, A.G., Mower, R.W., and Horr, C.A., 1968, Hydrologic and climatologic data, 1967, Salt Lake County, Utah: U.S. Geological Survey, Utah Basic-Data Release no. 15, 74 p.

Hood, J.W., 1971, Hydrologic reconnaissance of the Park Valley area, Box Elder County, Utah: Utah Department of Natural Resources Technical Publication no. 30, 51 p.

Hood, J.W., 1972, Hydrologic reconnaissance of the Promontory Mountains area, Box Elder County, Utah: Utah Department of Natural Resources Technical Publication no. 38, 42 p.

Hood, J.W., Mundorff, J.C., and Price, Don, 1976, Selected hydrologic data, Uinta Basin area, Utah and Colorado: U.S. Geological Survey, Utah Basic Data Release no. 26, 321 p.

Hood, J.W., and Price, Don, 1970, Hydrologic reconnaissance of Grouse Creek Valley, Box Elder County, Utah: Utah Department of Natural Resources Technical Publication no. $29,54 \mathrm{p}$.

Hood, J.W., Price, Don, and Waddell, K.H., 1969, Hydrologic reconnaissance of Rush Valley, Tooele County, Utah: Utah Department of Natural Resources Technical Publication no. $23,63 \mathrm{p}$.

Hood, J.W., and Rush, F.E., 1965, Water-resources appraisal of the Snake Valley area, Utah and Nevada: Utah Department of Natural Resources Technical Publication no. 14, 40 p.

Hood, J.W., and Waddell, K.M., 1968, Hydrologic reconnaissance of Skull Valley, Tooele County,-Utah: Utah Department of Natural Resources Technical Publication no. 18, 57 p.

Iorns, W.V., Mower, R.W., and Horr, C.A., 1966A, Hydrologic and climatologic data collected through 1964, Salt Lake County, Utah: U.S. Geological Survey, Utah BasicData Release no. 11, 91 p. 
Iorns, W.V., Mower, R.W., and Horr, C.A., 1966B, Hydrologic and climatologic data 1965, Salt Lake County, Utah: U.S. Geological Survey, Utah Basic-Data Release no. 12, 84 p.

Klauk, R.H., 1984, Low-temperature geothermal assessment of the Jordan Valley, Salt Lake County, Utah (with a section on temperature-depth measurements by Riki Darling): Utah Geological and Mineral Survey Report of Investigation no. 185, 160 p.

Klauk, R.H., and Davis, D.A., 1984, Evaluation of low-temperature geothermal potential in Utah and Goshen Valleys and adjacent areas, Utah County, Utah, Part II - water temperature and chemistry: Utah Geological and Mineral Survey Report of Investigation $191,45 \mathrm{p}$.

Klauk, R.H., and Gourley, Chad, 1983, Geothermal assessment of a portion of the Escalante Valley, Utah: Utah Geological and Mineral Survey Special Study 63, 57 p.

Klauk, R.H., and Prawl, C.A., 1984, Geothermal assessment of part of the East Shore area, Davis and Weber Counties, Utah: Utah Geological and Mineral Survey Report of Investigation $183,46 \mathrm{p}$.

Kohler, J.F., 1979, Geology, characteristics, and resource potential of the low-temperature geothermal system near Midway, Wasatch County, Utah: Utah Geological and Mineral Survey Report of Investigation 142, 64 p.

Lee, W.T., 1908, Water resources of Beaver Valley, Utah: U.S. Geological Survey WaterSupply Paper 217, 57 p.

Lienau, P.J., and Ross, H.P., 1994, Low-temperature resource assessment program: U.S. Department of Energy, Geothermal Division Program Review XI.

Lines, G.C., 1978, Selected ground-water data, Bonneville Salt Flats and Pilot Valley, Western Utah: U.S. Geological Survey, Utah Basic-Data Release no. 30, 14 p.

Mabey, D.R., and Budding, K.E., 1987, High-temperature geothermal resources of Utah: Utah Geological and Mineral Survey Bulletin 123, 64 p.

Marine, I.W., 1960, Geology and ground-water resources of Jordan Valley, Utah: University of Utah, Department of Geology and Geophysics, Ph. D. thesis, 202 p.

Marine, I.W., and Price, Don, 1963, Selected hydrologic data, Jordan Valley, Salt Lake County, Utah: U.S. Geological Survey, Utah Basic-Data Report no. 4, 30 p. 
Mariner, R.H., Presser, T.S., and Evans, W.C., 1977, Chemical, isotopic, and gas compositions of selected thermal springs in Arizona, New Mexico and Utah: U.S. Geological Survey Open-File Report 77-654, 42 p.

Mariner, R.H., Presser, T.S., and Evans, W.C., 1983, Geochemistry of active geothermal systems in the northern Basin and Range Province: Geothermal Resources Council Special Report 13, p. 95-120.

McGreevy, L.J. and Bjorkland, L.J., 1970, Selected hydrologic data, Cache Valley, Utah and Idaho: U.S. Geological Survey, Utah Basic-Data Release no. 21, 51 p.

McHugh, J.B., Ficklin, W.H., Miller, W.R., and Preston, D.J., 1981, Analytical and statistical results for 486 water samples from the $1^{\circ}$ X $2^{\circ}$ Richfield Quadrangle, Utah: U.S. Geological Survey Open-File Report 81-731, 31 p.

Meinzer, O.E., 1911, Ground water in Juab, Millard, and Iron Counties, Utah: U.S. Geological Survey Water-Supply Paper no. 227, 162 p.

Mower, 1963, Selected hydrologic data, Pavant Valley, Millard County, Utah: U.S. Geological Survey, Utah Basic-Data Report no. 5, 20 p.

Mower, R.W., and Cordova, R.M., 1974, Water resources of the Milford area, Utah, with emphasis on ground water: Utah Department of Natural Resources, Division of Water Rights, Technical Publication, no. 43, 106 p.

Mower, R.W., and Feltis, R.D., 1964, Ground-water data, Sevier Desert, Utah: U.S. Geological Survey, Utah Basic-Data Report no. 9, 34 p.

Muffler, L.J.P., editor, 1979, Assessment of geothermal resources of the United States - 1978: U.S. Geological Survey Circular 790, 163 p.

Mundorff, J.C., 1970, Major thermal springs of Utah: Utah Geological and Mineral Survey Water Resources Bulletin 13, 60 p.

Murphy, P.J., and Gwynn, J.W., 1979, Geothermal investigations at selected thermal systems of the northern Wasatch Front, Weber and Box Elder Counties, Utah: Utah Geological and Mineral Survey Report of Investigation 141, $50 \mathrm{p}$.

Parry, W.T., Benson, N.L., Miller, C.D., 1976, Geochemistry and hydrothermal alteration at selected Utah hot springs: Salt Lake, University of Utah, Final Report, Volume 3, 131 p. 
Parry, W.T., and Cleary, M.D., 1978, Na-K-Ca and silica temperature estimates from Utah spring and well waters: University of Utah, Department of Geology and Geophysics Final Report, v. 78-1 under U.S. Geological Survey contract 14-08-0001-G-341, 51 p.

Petersen, C.A., 1973, Roosevelt and thermo hot springs, Beaver County, Utah, in: Geology of the Milford area 1973: Utah Geological Association Publication 3, p. 73-74.

Phillips Petroleum Company, 1976, Selected water analyses of Roosevelt KGRA: unpublished report, $1 \mathrm{p}$.

ReMillard, M.D., Herbert, L.R., Birdwell, G.A., and Lockner, T.K., 1992, Water resources data - Utah water year 1991: U.S. Geological Survey Water-Data Report UT-91-1, 375 p.

Richardson, G.B., 1907, Underground water in Sanpete and central Sevier Valleys, Utah: U.S. Geological Survey Water-Supply Paper no. 199, 63 p.

Robinson, G.B., Jr., 1968, Selected hydrologic data, San Pitch River drainage basin, Utah: U.S. Geological Survey, Utah Basic-Data Release no. 14, 44 p.

Ross, H.P., Nielson, D.L., and Moore, J.N., 1982, Roosevelt Hot Springs geothermal system, Utah - case study: American Association of Petroleum Geologists Bulletin, v. 66, no. 7, p. 879-902.

Ross, H.P., Blackett, R.E., and Shubat, M.A., 1991, Wood Ranch thermal anomaly: Utah Geological Survey Miscellaneous Publication 91-4, 21 p.

Ross, H.P., Blackett, R.E., Shubat, M.A., and Gloyn, R.W., 1993, Self-potential and fluid chemistry studies of the Meadow-Hatton and Abraham Hot Springs, Utah: Geothermal Resources Council Transactions, v. 17, p. 167-174.

Rush, F.E., 1977, Subsurface-temperature data for some wells in western Utah: U.S. Geological Survey Open-File Report 77-132, 36 p.

Rush, E.F., 1983, Reconnaissance of the hydrothermal resources of Utah: U.S. Geological Survey Professional Paper 1044-H, 44 p.

Sandberg, G.W., 1963, Ground-water data Beaver, Escalante, Cedar City, and Parowan Valleys parts of Washington, Iron, Beaver, and Millard Counties, Utah: U.S. Geological Survey, Utah Basic-Data Report no. 6, 26 p.

Sass, J.H., Lachenbruck, A.H., and Munroe, R.J., 1974, Basic heat-flow data from the United States: U.S. Geological Survey Open-File Report 74-9, 426 p. 
Saxon, F.C., 1972, Water-resource evaluation of Morgan Valley, Morgan County, Utah: M.S. Thesis, University of Utah, $118 \mathrm{p}$.

Smith, R.E., 1961, Records and water-level measurements of selected wells and chemical analyses of ground water, East Shore area, Davis, Weber and Box Elder Counties, Utah: U.S. Geological Survey, Utah basic-data report no. 1, 35 p.

Stephens, J.C., 1974A, Hydrologic reconnaissance of the northern Great Salt Lake Desert and summary hydrologic reconnaissance of northwestern Utah: Utah Department of Natural Resources Technical Publication no. 42, 55 p.

Stephens, J.C., 1974B, Hydrologic Reconnaissance of the Wah Wah Valley drainage basin, Millard and Beaver Counties, Utah: Utah Department of Natural Resources Technical Publication no. 47, 53 p.

Stephens, J.C., 1977, Hydrologic reconnaissance of the Tule Valley drainage basin, Juab and Millard Counties, Utah: Utah Department of Natural Resources Technical Publication no. $56,37 \mathrm{p}$.

Subitsky, Seymour, 1962, Records of selected wells and springs, selected drillers' logs of wells and chemical analyses of ground and surface waters, northern Utah Valley, Utah County, Utah: U.S. Geological Survey, Utah Basic-Data Report no. 2, 14 p.

Swanberg, C.A., Morgan Paul, Stoyer, C.H., and Witcher, J.C., 1977, An appraisal study of the geothermal resources of Arizona and Adjacent areas in New Mexico and Utah and their value for desalination and other uses: New Mexico Energy Report no. 006, 76 p.

Turk, L.J., 1973, Hydrogeology of the Bonneville Salt Flats, Utah: Utah Water Resources Bulletin no. 19, $81 \mathrm{p}$.

Union Oil Company, 1978, Geologic report of the Cove Fort-Sulphurdale geothermal unit area, Millard and Beaver Counties, Utah: Earth Science Laboratory/University of Utah Research Institute Open-File Report UT/CFS/UOC-1.2, 33 p.

Utah Energy Office, 1981, Resource assessment report, Crystal Hot Springs geothermal area: Utah Energy Office Report, no. DOE/ET 27027-4, 108 p.

Utah Geological and Mineral Survey, compilers, 1980, Geothermal resources of Utah, 1980: Map prepared by the National Oceanic and Atmospheric Administration for the U.S. Department of Energy, scale 1:500,000.

Wilson, W.R., and Chapman, D.S., 1980, Three topical reports: I. Thermal studies at Roosevelt Hot Springs, Utah; II. Heat flow above an arbitrarily dipping plane of heat sources; III. A datum correction for heat flow measurements made on an arbitrary surface: Earth Science Laboratory/University of Utah Research Institute Report, no. DOE/ID/12079-19, $144 \mathrm{p}$. 


\section{WELL AND SPRING NUMBERING-SYSTEM \\ USED IN UTAH}

The system of numbering wells and springs in Utah is based on the cadastral land-survey system of the U.S. Government. The number designates a location and describes its position in the land net. The land-survey system divides the state into four quadrants by the Salt Lake Base Line and Meridian, and these quadrants are designated by uppercase letters as follows: A, northeast, B., northwest; $C$, southwest; and D, southeast. Numbers designating the township and range (in that order) follow the quadrant letter, and all three are enclosed in parentheses. The number after the parentheses indicates the section and is followed by the three letters indicating the quarter section, the quarter-quarter section, and the quarter-quarter-quarter section (generally $4 \mathrm{~km}^{2}$ or 10 acres). The quarters of each subdivision are designated by lowercase letters as follows: $a$, northeast; $b$, northwest; $c$, southwest; and d, southeast.

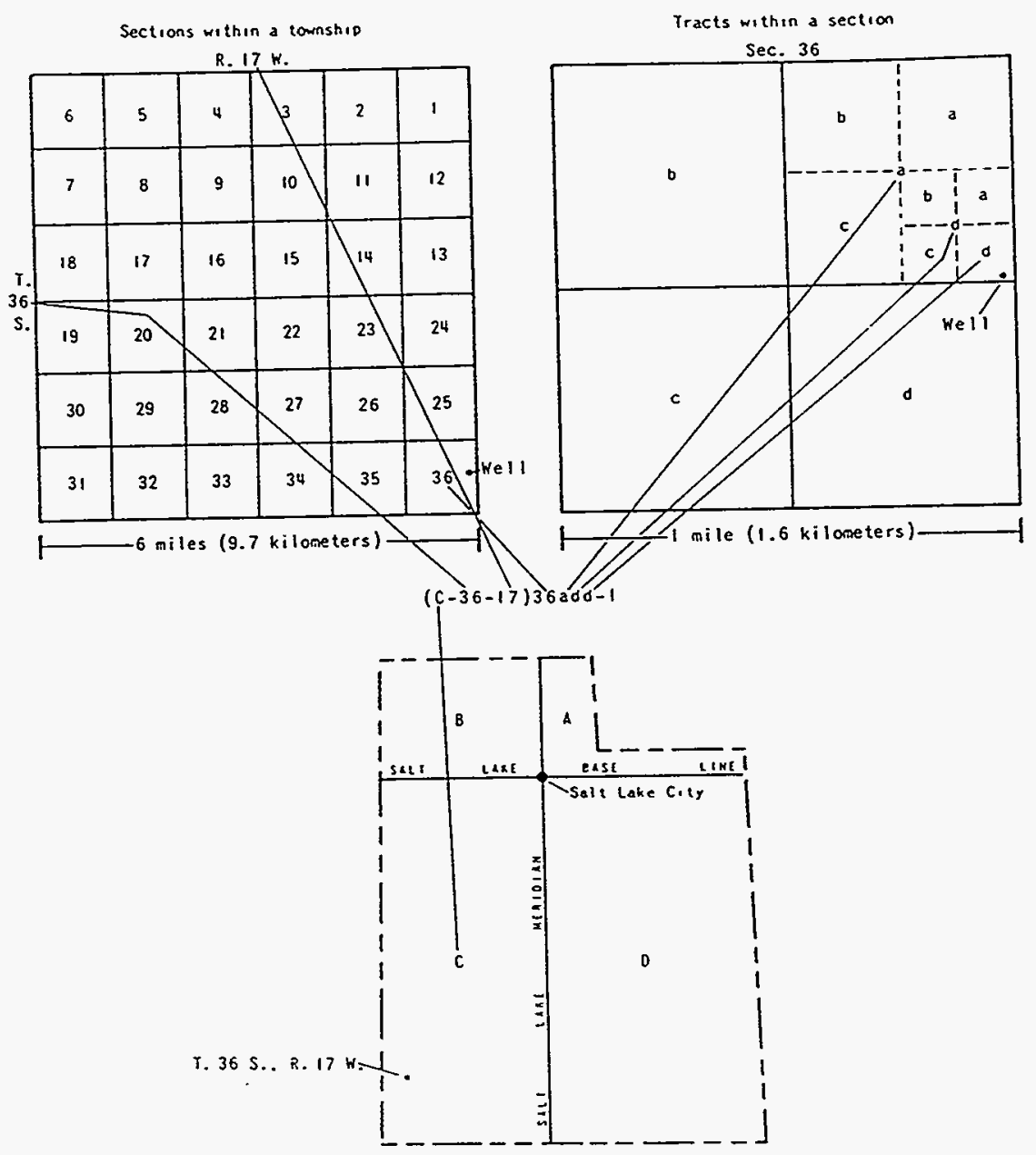


APPENDIX A

LOCATION AND DESCRIPTION INFORMATION FOR GEOTHERMAL WELLS AND SPRINGS IN UTAH 
ID MAP NO. SOURCE NAME

1 BE-01 unnamed

2 BE-02 Utah State 42-7

3 BE-03 C. Anderson

4 BE-04 Salt Spr.

5 BE-04 Salt Spr.

$6 \mathrm{BE}-05$ Roosevelt Hot Spr.

7 BE-05 Roosevelt Hot Spr.

$\begin{array}{lll}8 & B E-05 & R o o s e v e l t ~ H o t ~ S p r \\ 9 & \text { BE-05 } & \text { Roosevelt Hot Spr }\end{array}$

10 BE-06 unnamed

11 BE-07 Tub Spr.

12 BE-08 unnamed

13 BE-09 unnamed

$14 \mathrm{BE}-10$ Thermal power $14-2$

15 BE-10 Thermal Power 14-2

16 BE-11 Phillips 54-3

17 BE-11 Phillips 54-3

$18 \mathrm{BE}-12$ Phillips 3-1

19
20

20 BE-14 Utah State 72-16

21 BE-14 Utah state $72-16$

22 BE-15 Utah state $52-21$

23 BE-15 Utah state $52-21$

BE-16 suldivan

unnamed

$\begin{array}{lll}26 & \mathrm{BE}-17 & \text { Mud Spr. } \\ 27 & \mathrm{BE}-18 & \mathrm{G} \text {. Sullivan }\end{array}$

28 BE-19 Town of Milford

28 BE-19 Town of Milfor

$30 \mathrm{BE}-21$ unnamed

$31 \mathrm{BE}-22$ E. Davie

B. Davie

$34 \mathrm{BE}-24$ G. Goodwin

$35 \mathrm{BE}-25$ T. Forgie

$36 \mathrm{BE}-26$ unnamed

$37 \mathrm{BE}-26$ unnamed

38 BE-27 L. Paice

39 BE-28 unnamed

40 BE-29 Prov, Holy Name

$41 \mathrm{BE}-30$ Green Diamond Ranch

42 BE-30 Green Diamond Ranch

$43 \mathrm{BE}-30$ Green Diamond Ranch

$44 \mathrm{BE}-31$ Green Diamond Ranch

$45 \mathrm{BE}-32$ Woodhouse Spr.

$46 \mathrm{BE}-33$ Sulphur Sp

47 BE-34 Beaver School Dist.

48 BE-35 S.R. Barton well

$49 \mathrm{BE}-36$ Minersville Res. Co.

$50 \quad \mathrm{BE}-37$ unnamed

$51 \mathrm{BE}-38 \mathrm{~J}$. Mayer

52 BE-39 unnamed $w$

$(\mathrm{C}-25-10) 26 \mathrm{dbb}$ (C-26-06) 07bad (C-26-07) 26cac (C-26-09) $34 \mathrm{bdd}$ (C-26-09) $34 \mathrm{bdd}$ (c-26-09) $34 d c b$ $(c-26-09) 34 d c b$
$(c-26-09) 34 d c b$ $(\mathrm{C}-26-09) 34 \mathrm{dcb}$
$(\mathrm{C}-26-09) 34 \mathrm{dcb}$ $(\mathrm{C}-26-09) 34 \mathrm{dcb}$
$(\mathrm{C}-26-10) 29 \mathrm{dbd}$ $(C-26-10) 29 d b d$ $(c-26-13) 25 a c c$ $(\mathrm{C}-27-07) 02 \mathrm{bcc}$
$(\mathrm{C}-27-08) 32 \mathrm{Ccc}$ ccC 38.4122 (c-27-09) $02 \mathrm{bcc} 38.4938$ (c-27-09) 03 aca (C-27-09) 03 aca (c-27-09)03aca 38.4941 (C) $27-09)$ (C2abb (C-27-09) $21 \mathrm{abb}$ 0) $310 \mathrm{ab} 38.4156$ (C-27-10) 31dcb (C-27-18) 28ddc (C-28-10) 05add (C-28-10) $14 \mathrm{bba}$ (C-28-10) 16dcc (C-28-10) 17cdc (C-28-10) 17cdc (C-28-10) 18 ac (C-28-10) $182 a$ (C-28-10) 19abc (C-28-10) $28 \mathrm{CCC}$ $(\mathrm{C}-28-10) 28 \mathrm{CCC}$ (C-28-10) 30cdc (C-28-10) $31 \mathrm{cad}$ (C-28-11) $12 \mathrm{abb}$ (C-28-11) $25 \mathrm{dcd}$ (C-28-12) 25ded (C-28-11) 25dcd (C-28-11) 25ddd (C-28-12) $29 \mathrm{dcc}$ (C-28-19) $03 \mathrm{CCC}$ $(\mathrm{c}-29-08) 25 \mathrm{cac}$ (C-29-08) $36 \mathrm{a}$ (C-29-09) 36b (C-29-10) 24 cab (C-29-11) 01add $(\mathrm{C}-29-11) 12 \mathrm{ddc}$
$(\mathrm{C}-29-11) 12 \mathrm{ddc}$ 38.5000 38.5000
38.5000 38.5000
LATITUDE LONGITUDE UTM.N UTM.E TEMP $38.6089 \quad 112.9431 \quad 4274961330810$ $\begin{array}{lllll}38.5685 & 112.5658 & 4269850 & 363500\end{array}$ $38.5169 \quad 112.61474264197359227$ $38.5075 \quad 112.8522 \quad 4263544338498$ $112.8333 \quad 4262679340127$ 12.83334262679340127 112.83334262679340127 112.99534265037326046 $\begin{array}{llll}113.2556 \quad 4265717 & 303354\end{array}$ 112.61314261365359317 12.77614252838344930 122.84094262000339450 $112.8490 \quad 4262050338750$ 112.84904262050338750 $112.8512 \quad 4261850 \quad 338550$ 112.86874260700337000 112.86494259075337300 112.86494259075337300 112.86744257600337050 $113.02814253650 \quad 323808$ 113.01814253650323808 $\begin{array}{llll}113.8592 & 4256726 \quad 250398\end{array}$ $38.4083 \quad 112.9914 \quad 4252500 \quad 326318$ $38.3920 \quad 113.0120 \quad 4251020324283$ $\begin{array}{lllll}38.3830 & 112.9490 & 4249903 & 329765\end{array}$ $\begin{array}{lllll}38.3700 & 112.9817 & 4248521 & 326877\end{array}$ $\begin{array}{lllll}38.3678 & 113.0036 \quad 4248318 \quad 324959\end{array}$ $38.3678 \quad 113.0036 \quad 4248318 \quad 324959$ $38.3810 \quad 133.0160 \quad 4249807323907$ $38.3650 \quad 113.0190 \quad 4248037323606$ $38.3386 \quad 112.9881 \quad 4245048 \quad 326243$ $\begin{array}{lllll}38.3386 & 112.9881 & 4245048 & 326243\end{array}$ $\begin{array}{lllll}38.3389 & 113.0225 & 4245147 & 323237\end{array}$ $\begin{array}{lllll}38.3286 & 113.0189 & 4243997 & 323527\end{array}$ $38.3963 \quad 113.03774251545 \quad 322045$ $\begin{array}{lllll}38.3389 & 113.0325 & 4245166 & 322363\end{array}$ $\begin{array}{lllll}38.3389 & 113.0325 & 4245166 & 322363\end{array}$ $\begin{array}{lllll}38.3389 & 113.0325 & 4245166 & 322363\end{array}$ $\begin{array}{llll}38.3389 & 113.0283 & 4245158 & 322730\end{array}$ $\begin{array}{lllll}38.3420 & 113.2230 & 4245894 & 305720\end{array}$ $\begin{array}{lllll}38.3939 & 113.9625 & 4253470 & 241265\end{array}$ $38.2544 \quad 112.7061 \quad 4235212350719$ $\begin{array}{lllll}38.2490 & 112.7000 & 4234603 & 351242\end{array}$ $\begin{array}{lllll}38.2370 & 112.8160 & 4233464 & 341064\end{array}$ $38.2690 \quad 112.9090 \quad 4237500 \quad 331250$ $\begin{array}{lll}38.3169 & 113.02814242716 \quad 322694\end{array}$ $\begin{array}{llll}38.2950 & 113.0314 & 4240292 & 322352 \\ 38.2950 & 113.0314 & 4240292 & 322352\end{array}$
DEPTH STA FLOW LEVEL $(\mathrm{L} / \mathrm{min})$

(m) 21.0 $178.0 \quad 2357.6$ $21.0 \quad 76.2$ 24.0 55.0 55.0 85.0 25.0 26.5 20.0 20.0 $268.0 \quad 1862.0$ $254.0 \quad 1862.0$ $260.0 \quad 878.0$ $225.0 \quad 2098.0$ $243.0 \quad 382.0$ $243.0 \quad 382.0$ $204.0 \quad 2289.0$ $27.0 \quad 700.0$ 21.0

93.0 $25.5 \quad 163.0$
2915.0

2328.0

79.0
96.3

$48.8 \mathrm{P}$

46.0
134.0

$31.4 \mathrm{P}$

$131.4 \mathrm{p}$

131.0

$45.7 \mathrm{P}$

$76.2 \mathrm{P}$

19.5

73.2
73.0

232.0

95.0

1892.7

2233.0

9463.5
9463.5

9464.0

2817.0

26.5

189.0

1741.3

2119.8 20.0 $\begin{array}{rr}20.5 & 67.0\end{array}$

$24.5 \quad 67.1$ 21.0 25.5 21.0 20.0 20.0 20.0

A-2
MeHugh and Miller, 1981
Ash and others, 1979 WATSTORE

Mower and Cordova, 1974 McHugh and others, 1981 Mower and Cordova, 1974 Ross and others, 1982 Mower and Cordova, 1974 Mariner and others, 1983 McHugh and Miller, 1981 McHugh and others, 1981 Mchugh and others, 1981 McHugh and others, 1981 Capuano and Cole, 1982 Ross and others, 1982 Ross and others, 1982 Mariner and others, 1983 Mariner and others, 1983 Ross and others, 1982 Capuano and Cole, 1982 Ross and others, 1992 Capuano and Cole, 1982 28.0 WATSTORE

McHugh and others, 1981 WATSTORE

Mower and Cordova, 1974 Mower and Cordova, 1974 McHugh and Miller, 1981 WATSTORE

Mower and Cordova, 1974 Lee, 1908

Mower and Cordova, 1974 WATSTORE

8.7 WATSTORE

Mctugh and Miller, 1981 4.4 WATSTORE

4,4 WATSTORE

6.7 Mower and Cordova, 1974

Mower and Cordova, 1974 McHugh and others, 1981

3.7 WATSTORE

Sand́berg, 1963

Lee, 1908

9.4 WATSTORE

McHugh and Miller, 1981 
ID MAP NO.

54 BE-40 Town of Minersville 55 BE-41 Dotson Warm Spr.

$56 \mathrm{BE}-41$ Dotson Warm Spr.

$58 \mathrm{BE}-41$ Dotson Warm Spr.

$59 \mathrm{BE}-42$ Bureau of Land Mgmt.

$60 \mathrm{BE}-43$ Willow Spr.

$61 \mathrm{BE}-44$ Neb Craw

$63 \mathrm{BE}-46$ Thermo Hot Spr.

$64 \mathrm{BE}-46$ Thermo Hot Spr.

$65 \mathrm{BE}-46$ Thermo Hot Spr.

$66 \mathrm{BE}-46$ Thermo Hot Spr.

$67 \mathrm{BE}-46$ Thermo Hot Spr.

$68 \mathrm{BE}-46$ Thermo Hot Spr.

$69 \mathrm{BE}-47$ Thermo Hot Spr.

$70 \mathrm{BE}-47$ Thermo Hot Spr.

$71 \mathrm{BE}-47$ Thermo Hot Spr.

Thermo Hot $\mathrm{spr}$

$74 \mathrm{BE}-49$ unnamed

$75 \mathrm{BO}-01$ Bureau of Land Mgmt.

76 BO-02 Bureau of Land Mgmt.

77 BO-03 Bureau of Land Mgmt.

$78 \mathrm{BO}-04$

79 BO-05 Compton

$80 \mathrm{BO}-06$

$81 \mathrm{BO}-07$

82 BO-07

$83 \mathrm{BO}-07$ W \&

84 BO-08 Utah Hot Springs

85 BO-09 LDS Church

86 BO- 10 R. Penton

87 BO-11 LDS Church

88 BO-12 unnamed

89 BO-13 Willard Bay

V. Poulsen

91 BO-15 Chesapeake Duck Club

92 BO-15 Chesapeak

94 BO-17 Jepperson

95 BO-18 Stinking Spr.

96 BO-18 stinking Spr.

97 BO-19 L. Anderson

98 BO-20 Spr. near Iittle Mtn.

99 BO-21 unnamed

100 BO-22 Little Mtn. Warm Spr.

101 BO-23 National Park Service $W$

102 BO-24 Warm Spx. \#2

$103 \mathrm{BO}-25 \mathrm{R}$. Warburto

104 BO-26 M. Tanner

105 BO-27 Kimber (Rose) Spr.

106 BO-28 B. Kimber
LOCATION

(C-30-09) 07adb (C-30-09) 07aca (c-30-09) 07aca (C-30-09) 07aca (c-30-09) 07aca (c-30-09) $19 \mathrm{bdc}$ (C-30-09) 31daa (C-30-10) 19abd (C-30-11) 22ddc (C-30-12) 21add (C-30-12) 2ladd (C-30-12) 2ladd (C-30-12) 2 ladd (C-30-12) 2ladd (C-30-12) 21add (C-30-12) 28 add (C-30-12) 28 add (C-30-12) $28 \mathrm{add}$ (C-30-12) 28add (C-30-13) 30 bdc (C-31-15) $32 \mathrm{aca}$ (B-04-17) 04bbb $(\mathrm{B}-04-17) 31 \mathrm{ccc}$ (B-04-18) $33 \mathrm{ccC}$ (B-05-13) $31 \mathrm{ac}$ (B-06-05) 21aa (B-07-02) $10 \mathrm{dbd}$ (B-07-02) 10 dbd (B-07-02) 10dbd (B-07-02) 14dca $(\mathrm{B}-07-02) 16 \mathrm{ba}$ (B-07-02) $16 \mathrm{bc}$ (B-07-02) 16dab $(\mathrm{B}-07-05) 15 \mathrm{~cd}$ (B-08-02) 21aa $(\mathrm{B}-08-05) 05 \mathrm{Ca}$ $(\mathrm{B}-09-03) 27 \mathrm{Cd}$ (B-09-03)27cd $(\mathrm{B}-10-02) 16 \mathrm{dc}$ (B-10-03) 04bb $(\mathrm{B}-10-03) 30 \mathrm{bba}$ (B-10-03) $30 \mathrm{bb}$ (B-10-04) $23 \mathrm{ba}$ (B-10-04) 23bb $(\mathrm{B}-10-04) 24 \mathrm{CC}$ $(B-10-06) 09 d d$ (B-10-15) $06 \mathrm{cb}$ (B-10-18) 17dbb (B-10-18) 21aa $(\mathrm{B}-10-18) 30 \mathrm{da}$
$(\mathrm{B}-10-18) 33 \mathrm{ca}$
LATITUDE LONGITUDE UTM.N UTM.E $\begin{array}{llll}38.2180 & 112.9060 \quad 4231514 \quad 333143\end{array}$ $38.2172 \quad 112.90394231422 \quad 333325$ $38.2172 \quad 112.9039 \quad 4231422 \quad 333325$ $38.2172 \quad 112.90394231422333325$ $38.2172 \quad 112.9039 \quad 4231422 \quad 333325$ $38.1862 \quad 112.9113 \quad 4228000332606$ $\begin{array}{lllll}38.1550 & 112.8960 & 4224505 & 333876\end{array}$ $38.1910 \quad 113.0140 \quad 4228718 \quad 323623$ $38.1790 \quad 113.0700 \quad 422749531868$ $\begin{array}{lllll}38.1860 & 113.1950 & 4228523 & 307757\end{array}$ $\begin{array}{lllll}38.1860 & 113.1950 & 4228523 & 307757\end{array}$ $\begin{array}{lllll}38.1860 & 113.1950 & 4228523 & 307757\end{array}$ $\begin{array}{lllll}38.1860 & 113.1950 & 4228523 & 307757\end{array}$ $\begin{array}{lllll}38.1860 & 113.1950 & 4228523 & 307757\end{array}$ $\begin{array}{llll}38.1860 & 113.1950 & 4228523 \quad 307757\end{array}$ $\begin{array}{llll}38.1730 & 113.2050 \quad 4227102 \quad 306846\end{array}$ $38.1730 \quad 113.2050 \quad 4227102 \quad 306846$ $\begin{array}{lllll}38.1730 & 113.2050 & 4227102 & 306846\end{array}$ $\begin{array}{lllll}38.1730 & 113.2050 & 4227102 & 306846\end{array}$ $\begin{array}{llll}38.1703 & 113.3533 \quad 4227122 & 293846\end{array}$ $\begin{array}{llll}38.0656 & 113.5511 & 4215961 & 276196\end{array}$ $\begin{array}{llll}41.0997 & 113.80894553416 \quad 264104\end{array}$ $41.0117 \quad 113.82364543962 \quad 254143$ $41.1080 \quad 113.3850 \quad 4553275299732$ $41.2380 \quad 112.4130 \quad 4565928 \quad 381588$ $\begin{array}{llll}41.3539 & 112.0750 \quad 4578389 & 410073\end{array}$ $\begin{array}{lll}4.3536 & 112.04814578329 & 412323\end{array}$ $\begin{array}{lllll}41.3536 & 112.0481 & 4578329 & 412323\end{array}$ $\begin{array}{lllll}41.3536 & 112.0481 & 4578329 & 412323\end{array}$ $\begin{array}{lllll}41.3387 & 112.0310 & 4576801 & 413819\end{array}$ $\begin{array}{llll}41.3387 & 112.0310 & 4576801 & 413819\end{array}$ $\begin{array}{llll}1.3370 & 112.0640 \quad 4576502 & 410970\end{array}$ $41.3422 \quad 112.0678 \quad 4577083410659$ $41.3320 \quad 112.4050 \quad 4576353 \quad 382428$ $41.4240 \quad 112.06804586165410755$ $41.4510 \quad 112.43904589611379802$ $41.5817 \quad 112.1770 \quad 4603787401884$ $41.5817 \quad 112.17704603787401884$ $41.6937 \quad 112.0820 \quad 4616118409960$ $41.6240 \quad 112.17804608488401865$ $41.5770 \quad 112.2350 \quad 4603336397042$ (112.2325 4603322397250 $41.6455 \quad 112.1845 \quad 4610882401356$ 600461391439511 $41.6703 \quad 112.2575 \quad 4613726 \quad 395317$ $41.6190 \quad 112.5460 \quad 4608417 \quad 371198$ $41.6130 \quad 113.6130 \quad 4609895282276$ $41.5867 \quad 113.9344 \quad 4607836 \quad 255394$ $41.5810 \quad 113.9090 \quad 4607132 \quad 257490$ $\begin{array}{llll}41.5640 & 113.9540 & 4605372 & 253674 \\ 41.5540 & 113.9110 & 4604139 & 257222\end{array}$

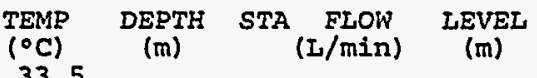

$\left({ }^{\circ} \mathrm{C}\right)$
33.5 35.5 32.5 33.5 31.5 33.0 21.5 22.5 78.0 85.0 50.0 56.0 42.0 89.5 66.0 66.0 93.0 24.0 24.0 20.0 21.5 22.0 21.0 25.5 24.0 24.0 25.0 22.0 25.0 22.0 74.0 74.0 107.0
25.0
47.5
47.0 47.0 24.5 26.0 22.0 20.0

24.5

20.0

20.0 (m)

89.0

50.0

3785 .

34.0

41.0

910.0

73.1

2.7
2.7

2.7
61.0

61.0

393.2

$238.4 \mathrm{P}$
$238.4 \mathrm{P}$

311.0

358.0
237.7

173.0

153.0

3354.0

$$
\text { F }
$$

94.6

76.0
57.0
7.6

129.0

$160.3 \mathrm{P}$

28.0

92.0

1461.0

3785.4
1325.0

1325.0

814.0
4277.0
REFERENCE

Mower and Cordova, 1974 McHugh and Miller, 1981 Mower and Cordova, 1974 Mchugh and others, 1981 Mower and cordova, 1974 Mower and Cordova, 1974 Mower and Cordova, 1974 Mower and cordova, 1974 Klauk and Courley 1983 Mower and cordova, 1974 Klauk and Gourley, 1974 Klauk and Gourley, 1983 Klauk and Gourley, 1983 Cole, 1983

Mariner and others, 1983 Mckugh and others, 1981 Mctugh and Miller, 1981 Mctugh and others, 1974 McFiugh and others, 1981

0.7 WATSTORE

0.4 WATSTORE

0.3 WATSTORE

Stephens, 1974 a

Hood, 1972

Bolke and waddell, 1972

-20.0 WATSTORE

MUTSTORE 1970

Bolke and waddell, 1972 Bolke and Waddell, 1972

-9.1 WATSTORE

Bjorklund and McGreevy, 1973 Hood, 1972

Bjorklund and McGreevy, 1973 Bjorklund and others, 1977 Goode, 1978

Bjorklund and McGreevy, 1973 Bjorklund and others, 1977 WATSTORE

Bjorklund and others, 1977 Bjorklund and others, 1977 Bjorklund and MCGreevy, 1973 Bjorklund and others, 1977 Hood, 1972

4.7 Hood, 1971

Hood and Price, 1970 Hood and Price, 1970
Hood and Price, 1970 
ID MAP NO. SOURCE NAME

107 BO-29 Crystal Spr. (Madsen) 108 BO-29 Crystal Spr. (Madsen)

209 BO-30 unnamed

$111 \mathrm{BO}-32$ unnamed Warburton

112 BO-33 Garland Springs

113 BO-34 L. King

114 BO-35 L. Harris

$115 \mathrm{BO}-36$ Town of

$116 \quad 80-37$ unnamed

118 BO-39 Warm Spr. \#1

119 BO-40 Cutler warm Spr.

220 BO-40 Cutler Warm Spr.

121 BO-41 Town of Plymouth

122 BO-42 Uddy/Belmont

123 BO-42 Uddy/Belmont

$\begin{array}{lll}124 & \text { BO-43 } & \text { Blue Creek Spring } \\ 125 & \text { BO-43 } & \text { Blue Creek Springs }\end{array}$

126 BO-44 L. Nessen

127 BO-44 L. Nessen

128 BO-45 R. Henrie

$129 \mathrm{BO}-46$ unnamed

$130 \mathrm{BO}-47$ unnamed

$131 \mathrm{BO}-48$ unnamed

132 BO- 49 unnamed

133 BO-50 L. Carter

134 BO-51 C. Larson

136 BO-53 Richardson, E.M.

137 BO-54 R. Pugsley

138 BO-55 head SpY.

139 BO-56 D. Stokes

140 BO-57 unnamed

142 BO-59 L. \& S. Victor

143 BO-60 L. \& S. Victor

144 BO-61 E. Tayior

$145 B O-62$ unnamed

146 BO-63 G. Hanna

147 BO-63 G. Hanna

148 BO-63 G. Hanna

$14980-64$ C. Taylor

150 BO-65 unnamed

151 BO-66 unnamed

152 BO-67 unnamed

153 BO-68 Hogan

154
$80-69$
$\mathrm{M}$. Palmex

155 BO-70 Hogan

$156 \mathrm{BO}-70$ Hogan

$157 \mathrm{BO}-71$ unnamed

159 BO-72 Coyote Spr.
TP

LOCATION $(\mathrm{B}-11-02) 29$ dad $(B-11-04) 34 b c$ $(B-11-04) 34 \mathrm{bd}$ $(\mathrm{B}-11-19) 11 \mathrm{ba}$ (B-12-02) 31dda $(\mathrm{B}-12-03) 15 \mathrm{cb}$ (B-12-04) $34 \mathrm{bba}$ (B-12-05) 22ba $(\mathrm{B}-22-06) 33 \mathrm{bc}$ (B-12-08) 10bcc $(B-12-15) 19 a a$ $(B-13-02) 27 d b d$ $(B-13-02) 27 \mathrm{abc}$ (B-13-03) 11ba (B-13-03) $23 \mathrm{bad}$ $(B-13-03) 23$ bad $(\mathrm{B}-13-05) 29 \mathrm{bcc}$ $(B-13-05) 29 b c c$ (B-13-05) 31daa (B-13-05) 31daa $(\mathrm{B}-13-06) 01 \mathrm{dbb}$ $(B-13-06) 07 \mathrm{ccc}$ $(\mathrm{B}-13-06) 17 \mathrm{CCC}$ (B-13-06) 30 cdc (B-13-08) 21dcd (B-13-12) $3 \mathrm{ca}$ $(\mathrm{B}-13-13) 34 \mathrm{Cd}$ $(B-13-13) 35 d d$ $(\mathrm{B}-13-13) 35 \mathrm{dd}$ $(B-13-16) 23 \mathrm{CC}$ (B-14-06) 09aa $(B-14-07) 05 a d b$ (B-14-07) 05ab (B-14-08) 05bdb $(\mathrm{B}-14-08) 05$ add (B-14-09) 04bbb (B-14-09) 04bcc (B-14-09) 04CCC (B-14-09) 04 CCC (B-14-09) 04 CCC (B-14-09) 04dd (B-14-09) 07bbb (B-14-09) 17 caa (B-14-10) 04bbc $(\mathrm{B}-14-10) 11 \mathrm{cbb}$ $(\mathrm{B}-14-10) 14 \mathrm{bbc}$ $(B-14-10) 15 \mathrm{cdC}$ $(\mathrm{B}-14-10) 23 \mathrm{bbb}$ $(\mathrm{B}-14-10) 33 \mathrm{bcc}$ $(B-14-10) 33$ bec
LATITUDE LONGITUDE UTM.N UTM.E TEMP

$\begin{array}{lllll}41.7483 & 112.0870 & 4622192 \quad 409620\end{array}$ $\begin{array}{lllll}41.7483 & 112.0870 & 4622192 \quad 409620\end{array}$ $41.7283 \quad 112.2862 \quad 4620200 \quad 393027$ $41.6417 \quad 112.2792 \quad 4610573 \quad 393464$ $41.6860 \quad 113.9820 \quad 4618998 \quad 251808$ $41.7303 \quad 112.1056 \quad 4620210 \quad 408048$ $41.7700 \quad 112.1750 \quad 4624694 \quad 402336$ $41.7350 \quad 112.2933 \quad 4620949392445$ $41.7570 \quad 112.3990 \quad 4623529 \quad 383694$ $41.7290 \quad 112.5400 \quad 4620621371916$ $41.7842 \quad 112.74224627070355222$ $41.7580 \quad 113.6030 \quad 4625970283596$ $41.8340 \quad 112.05604631671412315$ $41.8340 \quad 112.0560 \quad 4631671 \quad 412315$ $41.9637 \quad 112.15134646170404592$ $\begin{array}{llll}41.8547 & 112.1572 & 4634076 & 403943\end{array}$ $41.8547 \quad 112.15724634076403943$ $41.8330 \quad 112.4540 \quad 4610882401356$ $41.8330 \quad 112.4540 \quad 4610882401356$ $41.8167 \quad 112.454746302350379175$ 41.8167 112.4547 4630235379175 1.8804112 .48584638295376731 $41.8503 \quad 112.5700 \quad 4634134369667$ $41.8872 \quad 112.5906 \quad 4638262368032$ $\begin{array}{lllll}41.8358 & 112.7500 & 4632813 & 354691\end{array}$ $41.8250 \quad 113.26004632602312310$ $41.8200 \quad 113.31004632158308142$ $41.8080 \quad 113.3280 \quad 4630866306611$ $41.8180 \quad 113.3090 \quad 4631933 \quad 308219$ $\begin{array}{llll}41.8330 & 113.3910 & 4633785 & 301454\end{array}$ $\begin{array}{lllll}41.8320 & 113.6530 & 4634313 \quad 279693\end{array}$ $\begin{array}{lllll}41.9680 & 112.4830 & 4647073 \quad 377115\end{array}$ $\begin{array}{lllll}41.9722 & 112.6508 & 4647794 & 363219\end{array}$ $\begin{array}{llllll}41.9722 & 112.6508 & 4647794 & 363219\end{array}$ $41.9756 \quad 112.7786 \quad 4648384 \quad 352638$ $41.9736 \quad 112.7847 \quad 4648172 \quad 352128$ $\begin{array}{lllll}41.9789 & 112.8811 & 4648931 & 344153\end{array}$ $\begin{array}{llll}41.9731 & 112.8814 \quad 4648288 \quad 344114\end{array}$ $\begin{array}{lllll}41.8333 & 112.8814 & 4632766 & 343773\end{array}$ $41.9667 \quad 112.8814 \quad 4647577 \quad 344098$ $\begin{array}{lllll}41.9667 & 112.8814 & 4647577 & 344098\end{array}$ $\begin{array}{lllll}41.9780 & 112.8800 & 4648830 & 344242\end{array}$ $\begin{array}{lllll}41.9431 & 112.8917 & 4644976 & 343187\end{array}$ $\begin{array}{lllll}41.9486 & 112.9594 & 4645713 & 337589\end{array}$ $\begin{array}{llll}1.9572 & 112.9592 & 4646667 & 337627\end{array}$ $\begin{array}{lllll}1.9483 & 112.9592 & 4645679 & 337605 \\ 41.9361 & 112.9750 & 4644354 & 336264\end{array}$ $41.9361 \quad 112.9750 \quad 4644354 \quad 336264$ $41.9347 \quad 112.95114644154 \quad 338242$ $\begin{array}{llll}41.9010 & 112.9990 & 4640503 & 334183 \\ 41.9006 & 112.9989 & 4640459 & 334190\end{array}$

\begin{tabular}{|c|c|c|c|c|c|}
\hline $\begin{array}{l}\text { TEMP } \\
\left({ }^{\circ} \mathrm{C}\right)\end{array}$ & $\begin{array}{l}\text { DEPTH } \\
(\mathrm{m})\end{array}$ & STA & $\begin{array}{c}\text { FLOW } \\
(\mathrm{L} / \mathrm{min})\end{array}$ & $\begin{array}{l}\text { LEVEL } \\
(\mathrm{m})\end{array}$ & REFERENCE \\
\hline 54.0 & & & 3600.0 & & Cole, 1983 \\
\hline 55.5 & & & & & Bjorklund and others, 1977 \\
\hline 22.0 & & & 38.0 & & Bjorklund and others, 1977 \\
\hline 21.0 & & & & & Bjorklund and MoGreevy, 1973 \\
\hline 42.0 & & & 852.0 & & Hood and Price, 1970 \\
\hline 27.0 & & & 1850.0 & & Cole, 1983 \\
\hline 20.0 & 84.0 & & 3028.0 & & Bjorklund and McGreevy, 1973 \\
\hline 20.0 & 93.3 & $\mathrm{P}$ & 1608.8 & 37.2 & WATSTORE \\
\hline 20.0 & & & & & Bolke and Price, 1972 \\
\hline 20.5 & & & 3.8 & & Bolke and Price, 1972 \\
\hline 30.0 & & & & & Davis and Kolesar, 1984 \\
\hline $\begin{array}{l}26.5 \\
23.0\end{array}$ & & & 1287.0 & & Hood, 1971 . \\
\hline 25.0 & & & 38.0 & & $\begin{array}{l}\text { Bjorklund and others, } 1977 \\
\text { Cole, } 1983\end{array}$ \\
\hline $\begin{array}{l}29.0 \\
51.0\end{array}$ & 183.0 & & 197.0 & & $\begin{array}{l}\text { Bjorklund and others, } 1977 \\
\text { Bjorklund and others, } 1977\end{array}$ \\
\hline 53.0 & & & 6050.0 & & Cole, 1983 \\
\hline 27.0 & & & 1800.0 & & Cole, 1983 \\
\hline $\begin{array}{l}28.0 \\
20.5\end{array}$ & 123.4 & $\mathrm{P}$ & 1324.9 & 8.2 & $\begin{array}{l}\text { Bolke and Price, } 1972 \\
\text { WATSTORE }\end{array}$ \\
\hline 20.5 & 123.0 & & & & Bolke and Price, 1972 \\
\hline 20.0 & 214.6 & $\mathbf{p}$ & 2195.5 & 36.9 & WATSTORE \\
\hline $\begin{array}{l}30.0 \\
22.0\end{array}$ & & & & & Davis and Kolesar, 1984 \\
\hline 21.0 & & & & & Davis and Kolesar, 1984 \\
\hline 24.0 & & & & & Davis and Kolesar, 1984 \\
\hline 25.0 & & & 19.0 & & Hood, 1971 \\
\hline 21.0 & & & & & Utah Geol. Survey \\
\hline 21.0 & & & & & Utah Geol. Survey \\
\hline 23.0 & & & & & Utah Geol. Survey \\
\hline 23.0 & & & & & Utah Geol. Survey \\
\hline 21.0 & & & 76.0 & & Hood, 1971 \\
\hline $\begin{array}{l}20.5 \\
24.0\end{array}$ & 225.0 & & & & Bolke and Price, 1972 \\
\hline $\begin{array}{l}24.0 \\
20.0\end{array}$ & & & & & Davis and Kolesar, 1984 \\
\hline 20.0 & 54.9 & & & & $\begin{array}{l}\text { WATSTORE } \\
\text { W }\end{array}$ \\
\hline 20.5 & 140.2 & & & 64.0 & WATSTORE \\
\hline 23.0 & 114.3 & & & & WATSTORE \\
\hline 20.5 & 111.3 & & & 57.9 & WATSTORE \\
\hline 21.0 & & & & & Davis and Kolesar, 1984 \\
\hline 21.5 & 109.7 & $\mathrm{P}$ & 7570.8 & 53.3 & WATSTORE \\
\hline 20.5 & 110.0 & & 7571.0 & & Baker, 1974 \\
\hline 22.0 & 107.0 & & & & Baker, 1974 \\
\hline 20.0 & & & & & Davis and Kolesar, 1984 \\
\hline 20.0 & 185.3 & & & & WATSTORE \\
\hline 20.0 & & & & & Davis and Kolesar, 1984 \\
\hline 21.0 & 120.4 & $\mathrm{p}$ & 4466.8 & & WATSTORE \\
\hline 23.5 & 256.0 & $\mathrm{p}$ & 3406.9 & 55.2 & WATSTORE \\
\hline 24.5 & 153.9 & & & 59.7 & WATSTORE \\
\hline 23.0 & & & & & Davis and Kolesar, 1984 \\
\hline $\begin{array}{l}20.0 \\
43.5\end{array}$ & 256.0 & & & & $\begin{array}{l}\text { WATSTORE } \\
\text { Baker } 1974\end{array}$ \\
\hline 29.0 & & & & & Davis and Kolesar, 1984 \\
\hline
\end{tabular}

A-4 
ID MAP NO.

160 BO-73 R. Tolman

161 BO-74 unnamed

O-75 unnamed

163 BO-76 C. Taylor

164 BO-76 C. Taylor

165 BO-77 J. Lee

$166 \mathrm{BO}-77$ J. Lee

168 B0-78 K. Jensen

168 BO-78 K. Jensen

170 BO-80 C. Taylor

$\begin{array}{lll}171 & \text { BO-81 } & \text { E. Taylor } \\ 172 & \text { BO-82 } & \text { unnamed }\end{array}$

173 BO-83 A. Beckstead

174 BO-84 K. Jensen

275 BO-85 unnamed

$177 \mathrm{CA}-01$ Benson Irr. Co.

$\begin{array}{ll}178 \mathrm{CA}-02 & \text { D. Bodrero }\end{array}$

$179 \mathrm{CA} 03$. Taylor

181 CA-05 Benson Irx. Co.

$182 \mathrm{CA}-06$ Benson Irr. Co.

$183 \mathrm{CA}-07$ C. Wennergren

$184 \mathrm{CA}-08$ A. Beckstead

$185 \mathrm{CA}-09$ W. Peart

$186 \mathrm{CA}-10$ F. Sears

$187 \mathrm{CA}-11 \mathrm{~F}$. Stetler

$188 \mathrm{CA}-12 \mathrm{~K}$. Linquist

$190 \mathrm{CA}-14$ G. Iisonbee

$191 \mathrm{CA}-15$ Gossner Cheese

$192 \mathrm{CA}-16$ Cache Valley Dairy

$193 \mathrm{CA}-17$ N. Galloway

$194 \mathrm{CA}-18$ unnamed

$\begin{array}{lll}195 \mathrm{CA}-18 & \text { unnamed } \\ 196 \mathrm{CA}-19 & \mathrm{~J} \text {. Nuttal1 }\end{array}$

$197 \mathrm{CA}-20$ W. Cardon

$198 \mathrm{CA}-22$ H. Cronquist

$199 \mathrm{CA}-22 \mathrm{~N}$. Brown

$200 \mathrm{CA}-23$ L. Hauser

201 CA-24 W. Toombs

203 CA-26 R. Seamons

$204 \mathrm{CA}-27 \mathrm{M}$. Falslev

205 CA-28 D. Gancheff

206 CA-28 D. Gancheff

$207 \mathrm{CR}-01$ unnamed

208 CR-02 unnamed

209 DA-01 F. Thalman

210 DA-02 A. Thalman

211 DA-03 L. Roueche

$T$

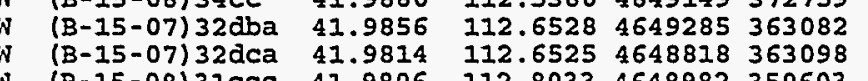
$\begin{array}{lllll}(B-15-08) 31 \mathrm{CCC} & 41.9806 & 112.8033 & 4648982 & 350603\end{array}$ (B-15-08)31CCC $41.9806 \quad 112.8033 \quad 464898235060$ $\begin{array}{lllll}(\mathrm{B}-15-09) 28 \mathrm{cbc} & 41.9989 & 112.8811 & 4651152 & 344202\end{array}$ (B-15-09)28cbC 41.9989 112.8811 4651152344202 $\begin{array}{llllll}\text { (B-15-09)28cbc } & 41.9989 & 112.8811 & 4651152 & 344202 \\ \text { (B-15-09)28dad } & 41.9986 & 112.8625 & 4651085 & 345742\end{array}$ $\mathrm{W}(\mathrm{B}-15-09) 29 \mathrm{bd} \quad 41.9980 \quad 112.8840 \quad 4651058343959$ $W \quad(B-15-09) 29 \mathrm{cbc} \quad 41.9986 \quad 112.90084651155342569$ W $(\mathrm{B}-15-09) 31 \mathrm{ad} \quad 41.9930 \quad 112.9070 \quad 4650545 \quad 342042$ $W \quad(B-15-09) 31 \mathrm{cdc} \quad 41.9797 \quad 112.91474649082341371$ $W \quad(B-15-09) 32 \mathrm{dab} \quad 41.9883 \quad 112.8856 \quad 4649983 \quad 343803$ W $\quad(B-15-09) 33 \mathrm{bbc} \quad 41.9908 \quad 112.88114650253 \quad 344182$ W $(B-15-09) 35 \mathrm{abb} \quad 41.9947 \quad 112.8328 \quad 4650599 \quad 348192$ W $\quad(B-15-09) 35 a b b \quad 41.9947 \quad 112.8328 \quad 4650599348192$ $\mathrm{W} \quad(\mathrm{A}-12-01) 16 \mathrm{cac} \quad 41.7772 \quad 111.84784625153429358$ W $(\mathrm{A}-12-01) 16 \mathrm{dba} \quad 41.7797 \quad 111.83874625035430104$ W $(A-12-01) 16$ ddd $41.7737 \quad 111.83624624583430931$ $W(A-12-01) 17 a d d \quad 41.7811 \quad 111.85284625611429129$ $W(A-12-01) 17$ daa $41.7783 \quad 111.85394625301429035$ $W(A-12-01) 17 d a b \quad 41.7783 \quad 111.8553462526842903$ $W \quad(A-12-01) 20$ bdd $41.7617 \quad 113.86674632642428533$ $W(A-12-01) 21 c a a \quad 41.7645 \quad 111.84334623816429843$ W (A-12-01) $21 \mathrm{cbd} 41.7625 \quad 111.84804623264429505$ W (A-12-01)22cCC $41.7600 \quad 111.8325462325443058$ (A-12-01)27aab $41.7555 \quad 111.81704623016432163$ (A-12-01) 28baa $41.7571 \quad 111.84364622939 \quad 429868$ (A-12-01)28Caa $41.7510 \quad 111.84384622261429845$ $(\mathrm{A}-12-01) 28 \mathrm{Cab} \quad 41.7502 \quad 111.8467 \quad 4622151429744$ (A-12-01)29acc $41.7519 \quad 111.8592 \quad 4622374 \quad 428565$ (A-13-01)19cac $41.8500 \quad 111.8863 \quad 4633176 \quad 426531$ (B-12-01) locdd 41.7875 111.9406 4626397421841 (B-12-01) 10ded $41.7872 \quad 111.9356 \quad 4626360 \quad 422256$ (B-12-01) 10ded $41.7872 \quad 111.93564626360422256$ (B-12-01) 10ded $41.7878 \quad 111.9367 \quad 4626225 \quad 422387$ (B-12-01)11cCC 41.7883 111.9294 4626476422772 (B-12-01) 2bcd $41.8097 \quad 111.9283 \quad 4628549423077$ (B-13-01) 10abc 41.8838 111.9395 4637002421841 (B-13-01) 10acb $41.8839 \quad 111.9394 \quad 4637099 \quad 42205$ (B-13-01)25bab 41.8450 111.9072 4632642424533 (B-13-01)27cdd $41.8312 \quad 111.8245 \quad 4631450 \quad 421780$ (B-13-01) 27Cdd 41.8312 111.8245 4631450421780 (B-13-01) 34daa $41.8228 \quad 111.9314 \quad 4630308 \quad 422648$ (B-14-01)33aac 41.9144 111.9550 4640500420801 (B-14-01) 33aac 41.9144 111.9550 4640500 420801 (D-12-11) 20aaa $39.7675 \quad 110.70834401784 \quad 524984$ (D-12-11) 21bab $39.7675 \quad 110.70034401786525670$ (B-02-01) 26cdd $40.8717 \quad 111.91954524524 \quad 42221$ (B-02-01) 27ddd $40.8725 \quad 111.9308 \quad 4524753 \quad 421632$ $\begin{array}{llllll}\text { (B-03-01) } 04 \mathrm{cdb} & 41.0195 & 111.9620 & 4541207 & 419452 \\ \text { (B-03-01) 05dda } & 41.0195 & 111.9695 & 4540772 & 418691\end{array}$
TEMP DEPTH STA FLOW LEVEL

REFERENCE

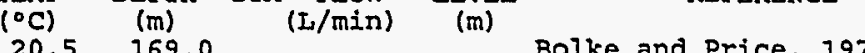

25.0

$24.0-167.6$

21.0

$24.0 \quad 121.9$ P 8857.9

$24.0 \quad 122.0 \quad 8858.0$

32.5

20.0
23.5

21.5

21.5

21.0
24.5
23.5
25.0

25.0
54.9
20.0
22.0

22.0

146.0

6000.0

121.9

8706.0

80.2

121.9 P 9463.5

125.0 P 9842.1

$55.0 \mathrm{~F} \quad 71.9$

$8.8 \mathrm{~F} \quad 227.0$

$46.9 \mathrm{P} \quad 1514.2$

$\begin{array}{ll}43.9 & F \quad 12.5\end{array}$

219.5
447.0

447.0
117.0

42.0
417.0

61.0

78.0

$32.9 \mathrm{P}$ 1676.4

216.4

162.5

162.5

$232.9 \mathrm{~F}$

1587.0

$\begin{array}{rrr}449.0 & \mathrm{~F} & 1135.6 \\ 283.5 & \mathrm{~F} & 162.8\end{array}$

283.0
216.0

2.0
284.0 2082.0 284.0 113.6

22.7

227.0

130.0

F 11.4

152.0

200.0
280.0 Davis and Kolesar, 1984
Davis and Kolesar, 1984 50.9 WATSTORE

Davis and Kolesar, 1984

65.2 WATSTORE

Davis and Kolesar, 1984

Bakex, 197

Baker, 1974

WATSTORE

Baker, 1974

\subsection{WATSTORE}

73.2 WATSTORE

Davis and Kolesar, 1984

McGreevy and Bjorklund, 1970 McGreevy and Bjorklund, 1970

-13.1 WATSTORE

MATSTORE McGreevy and Bjorklund, 1970 McGreevy and borkind, 1970 McGreevy and Bjork und 1970 Mcerevy and Bjorkiund, 1970 McGreevy and B jorklund, 1970 de Vries, 1982 (196klund, 1970 de Vries, 1982

MCGreevy and Bjorklund, 1970 -9.4 WATSTORE MCGreevy and Bjorklund, 1970 WATSTORE de Vries, 1982

MCGreevy and Bjorklund, 1970 de Vries, 1982

McGreevy and Bjorklund, 1970 MCGreevy and Bjorklund, 1970 de Vries, 1982

McGreevy and Bjorklund, 1970 McGreevy and Bjorklund, 1970 de Vries, 1982

de Vries, 1982

McGreevy and Bjorklund, 1970 WATSTORE

Bolke and Waddell, 1972

Bolke and Waddeli', 1972

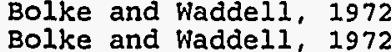


ID MAP NO.

SOURCE NAME

213 DA-05 W. Harris

214 DA-06 Davis Co.

Davis Co.

216 DA-07 Wheeler Machinery Co.

218 DA-08 Farmington Bay Refuge

219 DA-09 Hill AFB No. 5

220 DA-10 GSLA

221 DA-10 GSLA

223 DA-12 Hi1l AFB No. 2

224 DA-12 Hooper hot Spr.

225 DA- 12 Hooper Hot $\mathrm{Spr}$.

226 DA-12 Hooper HoL Spr.

227 DA-13 SW Hooper Warm Spr.

228 DU-01 Warm Spr.

229 DU-02 unnamed

$230 \mathrm{EM}-01$

$231 \mathrm{EM}-02$

$232 \mathrm{EM}-03$

$234 \mathrm{EM}-05$

$235 \mathrm{EM}-06$

235
$\mathrm{BM}-07$

$238 \mathrm{EM}-0$

Unnamed

Ureau of Land Mgmt.

.S. Forest Service unnamed

Bureau of Land Mgmt. Bureau of Land Mgmt. Roadside Geyser

(3)

241 $G A-01$ unnamed

$24 \mathrm{GA}-02$ unnamed

242 GA-03 unnamed

244 GA-05 05 una

245 GA-06 Lafevre's Spr.

246 GA-07 Lafevie S Spr.

247 GA-0B Dead cows Spr.

248 GA-09 unnamed

249 GA-10 Upper Hog Spr.

250 GA-12 upper Hog Spr.

$251 \mathrm{GA}-12$ Salt Spr.

252 GA-13 Saleratus Spr.

253 GA-14 Shitamaring Mine

254 GA -15 Shitamaring Mine

255 GA-16 Shitamaring Spr.

$256 \mathrm{GA}-17$

$257 \mathrm{GA}-18$

258 GA -1

icaboo Spr.

Honey Pot Spr.

Ticaboo Development

$260 \mathrm{GA}-21$

Mule Spr.

Bureau of Land Mgmt.

262 GR-02 Bureau of Land Mgmt.

$263 \mathrm{GR}-03$

National

65 GR-04
$T P$

(B-03-01) 09aad

LATITUDE LONGITUDE UTM.N

UTM. E

$41.0137 \quad 111.9503 \quad 4540200420198$ $111.94474538942 \quad 420546$

(B-03-01) 15 bac

.

I5ada 40.969

$(B-03-01) 27 a d a$

B-03-01) 35aba

(B-04-03) $19 \mathrm{caa}$

41.1045

B-04-03) $19 \mathrm{caa}$

41.0650

41.0650

(B-05-03) $27 \mathrm{cbd}$

(B-05-03) 27cbd

$(B-05-03) 28 d a c$
$(B-01-08) 30 d d *$

$(D-11-16) 25 \mathrm{dd}$

(D-16-08) 28 add

$(D-16-13) 20$ dab

$(D-17-06) 14 \mathrm{bcb}$

(D-17-12) 23 aba

(D-17-13) 03 abd

D-18-11) 33 acd

D-18-14) 09dcd

D-22-06) 04 cab

(C-31-02) 28 add

C-32-03) $21 d d b$

1.1408

41.1370

41.1370

41.1370
40.4500

39.8239

39.4033

39.4158
39.3461

39.3219

39.3378

39.2153

9.2638

38.9317

38.0075

38.0039

$(\mathrm{C}-32-4.5) 07 \mathrm{cb}$

(c-32-4.5) $23 \mathrm{cb}$

38.0414

38.0128

37.9353
37.9333

37.6247

$(C-33-05) 17 a c$

(D-31-09) $17 \mathrm{cba}$

$(\mathrm{D}-32-08) 21 \mathrm{dba}$

$(D-33-13) 05 \mathrm{dbc}$

(D-35-09) $13 \mathrm{cbc}$

(D-35-10) 20 aac

38.1097

37.9630

37.7630
37.7553

37.7512

37.7575

37.7570

37.7483

$\begin{array}{llll}110.7582 & 4178580 & 526339 \\ 1105959 & 537010\end{array}$

(D-35-11) $16 \mathrm{dcd}$

D-35-11) 21abb

(D-36-11) 06aca

$(D-36-11) 16 a b a$

(D-36-11) $32 \mathrm{cad}$

(D-22-23) 25 aaa

(D-22-23) 29 ada

(D-23-21) $27 \mathrm{bcd}$

(D-25-21) $26 \mathrm{dcC}$
$(\mathrm{D}-25-21) 26 \mathrm{dcC}$

(10.6964 $4170738 \quad 526769$

$\begin{array}{llll}37.6787 & 110.6020 & 4170181 \quad 535096\end{array}$

$\begin{array}{llll}38.8661 & 109.3286 & 4303037 \quad 645010\end{array}$

$38.8647 \quad 109.3908 \quad 4302785 \quad 639616$

$\begin{array}{llll}38.7817 & 109.5933 \quad 4293284 & 622188\end{array}$

$\begin{array}{llll}38.5942 & 109.5692 & 4272510 & 624606 \\ 38.5942 & 109.5692 & 4272510 & 624606\end{array}$

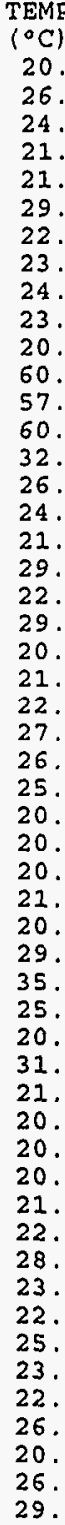

$\left({ }^{\circ} \mathrm{C}\right)$
20.0
26.0
24.0
21.0
21.0
29.0
22.0
23.5
24.0
23.0
20.0
60.0
57.0
60.0
32.2
26.0
24.0
21.0
29.0
22.5
29.0
20.0
21.0
22.0
27.8
26.0
25.0
20.0
20.0
20.0
21.0
20.0
29.0
35.6
25.0
20.0
31.0
21.0
20.0
20.0
20.0
21.0
22.0
28.0
23.0
22.0
25.0
23.0
22.5
26.5
20.0
26.5
29.5 $\begin{array}{c}\text { DEPTH } \\ (\mathrm{m})\end{array} \quad$ (L $\left./ \mathrm{min}\right)$ LEVEL

REFERENCE

$198.0 \quad 197.5$

300.2 P

$300.2 \mathrm{P}$

$259.1 \mathrm{P}$

259.0

372.0

245.0

131.1

131.1

197.0

3.8

(m)

Bolke and Waddell, 1972

$\begin{array}{lll}95.0 & -18.3 & \text { WATSTORE } \\ & -18.3 & \text { WATSTORE }\end{array}$

$143.9-13.1$ WATSTORE

Bolke and Waddell,' 1972 WATSTORE

\section{WATSTORE}

1059.9

757.0
3.8

123.5

(1)

0.4

55.0

Bolke and Waddell, 1972

Bolke and Waddell, 1972

Mundorff, 1970

Cole, 1983

Murphy and Gwynn, 1979

Hood and others, 1976

WATSTORE

WATSTORE

WATSTORE

WATSTORE

WATSTORE

Feltis, 1966

WATSTOR

McHugh and others, 1981

Mollugh and others, 198

Mctugh and others, 1981

McHugh and others, 1981

1060.0

2450.0

57.0

38.0

7.6
15.0

15.0
3.8

3.8
3.8

$152.4 \quad \mathrm{P}$

3.8
113.6

284.0

$295.7 \mathrm{P}$

7.6

492,1
19.0

0.8
0.8

$274.3 \stackrel{P}{\mathrm{P}}$

30.3

227.7 WATSTORE

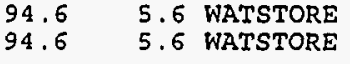

Carpenter and others, 1964

Aubrey, 1992

WATSTORE

Goode, 1978

36.6 WATSTÓR

Goode, 1978

Goode, 1978

Goode, 1978

135.6 WATSTOR

Goode, 1978

Goode, 2978

WATSTORE

$16.8 \mathrm{P}$ 
ID MAP NO. SOURCE NAME

266 GR-04 Suburban Gas Co.

267 GR-05 unnamed

268 GR-05 unnamed

269 IR-0I unnamed

270 IR-02 unnamed

271 IR-03 Big Maple Spr.

272 IR-04 unnamed

273 IR-05 unnamed

274 IR-06 unnamed

275 IR-07 unnamed

276 IR-08 Buckehorn Corp.

277 IR-09 unnamed

278 IR-10 Lehi Wood

279 IR-10 Lehi Wood

280 IR-11 unnamed

281 IR-12 unnamed

282 IR-13 unnamed

283 IR-14 unnamed

284 IR-15 L. Jones

286 IR-17 unnamed

$\begin{array}{lll}287 & \text { IR-18 } & \text { R. Holt } \\ 288 & \text { IR-19 } & \text { U.S. Steel Corp }\end{array}$

289 IR-20 Columbia Iron

290 IR-21 Bar V Ranch

291 IR-2I Bar V Ranch

292 IR-22 S. Tullis

$\begin{array}{lll}293 & \text { IR-23 } & \text { D. Tullis } \\ 294 & \text { IR-23 } & \text { D. Tullis }\end{array}$

295 IR-24 Hildebrande

296 IR-25 V. Pickerel

297 IR-26 Troy Hygro

299 IR-27 Christensen Bros.

300 IR-28 G. Vandenburge

301 IR-29 G. Vandenburge

302 IR-30 J. Prestwich

303 IR -31

304 JU-01

306 JU-03

307 JU-03

308 J0-04 Fish \& Wildlife Serv.

309 JU-05 Fish \& Wildlife Serv.

311 JU-06 Fish \& Wildlife Serv.

312 JU-07 D. Bagley

313 JU-08 unnamed

$314 \mathrm{JU}-09$ R. Iunt

$315 \mathrm{JU}-10$ Bureau of Land Mgmt. S

$316 \mathrm{JU}-11$ Bureau of Land Mgmt.

$318 \mathrm{JU}-13$ unnamed
TP

LOCATION

LATITUDE LONGITUDE UTM.N

UTM.E (D-25-21)35ddc $38.7131 \quad 109.5986 \quad 4285664 \quad 621844$ W (D-25-21)35ddc 38.7131 109.5986 $4285664 \quad 621844$ ? $(c-31-08) 36 \mathrm{cbc} \quad 38.0614 \quad 112.71834213815 \quad 349254$ (C-3I-09) 03cba $38.1383 \quad 112.86334222782 \quad 336734$ (C-31-11)28dac $38.0778 \quad 113.08694216298 \quad 31695$ (c-31-12) 30cdd 38.0711 113.2419 4215871303340 (c-31-14) ogbab $38.1233 \quad 113.40314222018289348$ (c-31-14)29aac $38.0050 \quad 113.43924208972285838$ (c-32-08) 12bac $38.0408 \quad 112.71224211548349414$ (C-33-16) 10ccc 37.9408 113.6386 4202325268126 $W$ (c-33-16) 11cdc $37.9403 \quad 113.61444202210270251$ (C-33-16) 11cdc $37.9403 \quad 113.61444202210270251$ (c-33-16) 14dcb $37.9456 \quad 113.63674202853268308$ (C-33-17) 20cbb 37.9250113 .78394200944255302 (c-33-18) 20bdd $37.8753 \quad 113.82114195526251865$ (C-34-11) 36acc 37.7958 113.0414 4184917 320261 (c-34-12) 36abb $37.8087 \quad 113.14834186594310819$ (c-34-16) $18 \mathrm{cb} 37.8390 \quad 113.68704191149263546$ (C-34-16) 22baa 37.8450 113.6283 4191668 268731 (C-34-17) 32cca 37.7981 113.7794 4186848255278 (C-36-15) 04dco 37.6250 123.5395 4175638276126 (c-36-15)07cdd $37.6778 \quad 113.57534172983272885$ (c-36-15) 07cdd $37.6778 \quad 113.57534172983272885$ (C-36-15) 07dba $37.6820 \quad 113.57304173444273100$ (c-36-15)17bba $37.6758 \quad 113.56154172724274100$ (c-36-15) $17 \mathrm{bba} 37.6758$ 113.5615 4172724273100 (c-36-15) 10ace 37.6688 113.5753 4172457272632 (C-36-15) 0 (C) $37.6505 \quad 113.56524171049273727$ (C-36-15) $20 \mathrm{bbd} 37.6595 \quad 133.56284170985273651$ (C-36-15) 20bbd $37.6595 \quad 113.56284170985273651$ (C-37-12) 11aaa $37.6017 \quad 133.16224163758309324$ (C-37-12) 11aab $37.6008 \quad 213.36424163655308968$ (c-37-12) 23 acb $37.5686 \quad 113.16894159959308450$ (C-37-16)04bde $37.5975 \quad 113.65314164264265770$ (C-11-14) 03dbd $39.8872 \quad 113.41314417815293664$ (C-11-14)05aab $39.9008 \quad 113.44924419409290618$ $\begin{array}{llllll}(C-11-14) 23 & 39.8417 & 113.3917 & 4412749 & 295334\end{array}$ (c-11-14)11bec $39.8772 \quad 113.4063 \quad 4416695294213$ (C-11-14)23aca $39.8500 \quad 123.39474413643 \quad 295126$ (C-11-14) 23ddc $39.8414 \quad 113.39334412686295221$ C-11-14) (C-11-14) 26add 39.8339 113.3906 (C-11-17) 12ded 39.8758 113.70444417264268165 (C-12-01) 12aac $39.7882 \quad 111.88074404277424734$ (c-12-02) 07dcd $39.7742 \quad 112.08724403052406889$ (C-12-12) 10cbd $39.7886 \quad 113.18944406378 \quad 312525$ (C-12-14) 23 dcc 39.7585 113.3894 4403357295563 $\begin{array}{lllll}(C-12-14) 23 \mathrm{dCC} & 39.7575 & 113.3864 & 4403357 & 295563 \\ (\mathrm{C}-13-18) 13 \mathrm{CaC} & 39.6925 & 113.8275 & 4397242 & 257542\end{array}$

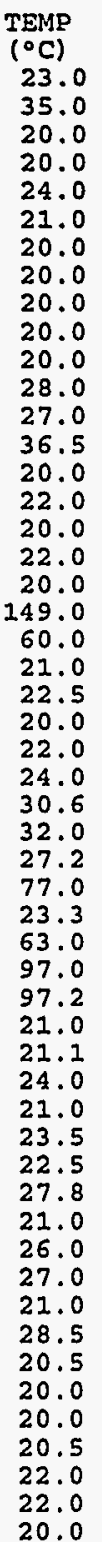

REFERENCE

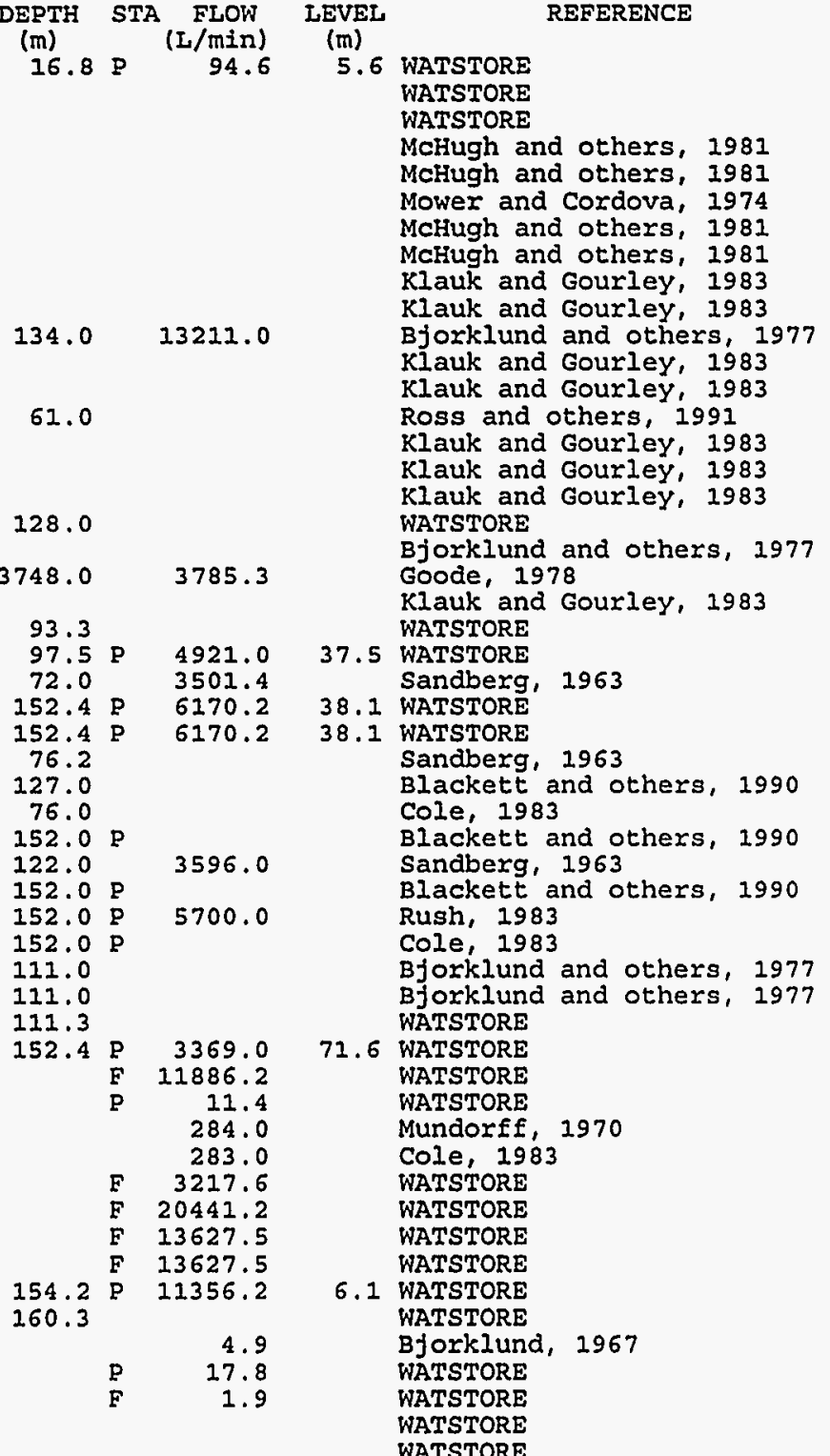


ID MAP NO. SOURCE NAME

319 JU-14 G. Nielson

$320 \mathrm{JU}-14$ G. Nielson

321 JU-15 Abraham Hot Spr.

322 JU-15 Abraham hot Spr.

323 JU-15 Abraham Hot Spr.

324 JU-15 Abraham Hot Spr.

325 JU-15 Abraham Hot Spr.

$326 \mathrm{JU}-16$ unnamed

328 JU-17 Bureau of Land Mgmt

$329 \mathrm{JU}-18$ unnamed

$330 \mathrm{KA}-01$ unnamed

331 KA-02 National Park Service

$332 \mathrm{KA}-03$ unnamed

$333 \mathrm{KA}-04$ unnamed

$334 \mathrm{KA}-05$ unnamed

$335 \mathrm{MI}-01$ J. Jones

$336 \mathrm{MI}-02$ Golden Harvey Irr.

337 MI-03 unnamed

$338 \mathrm{MI}-04$ MX Site

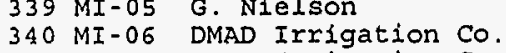

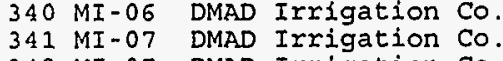

$342 \mathrm{MI}-07$ DMAD Irrigation Co.

343 MI-08 Bureau of Land Mgmt.

344 MI-09 Gandy Warm Spr.

346 MI-09 Gandy Warm Spr.

$346 \mathrm{MI}-10$ DMAD Irrigation Co.

$348 \mathrm{MI}-21$ DMAD Irrigation Co.

$349 \mathrm{MI}-11$ DMAD Irrigation Co.

$350 \mathrm{MI}-12$ DMAD Irrigation Co.

$351 \mathrm{MI}-12$ DMAD Irrigation Co.

352 MI-13 DMAD Irrigation Co.

353 MI-14 Town of Delta

$354 \mathrm{MI}-15$ D. Hansen

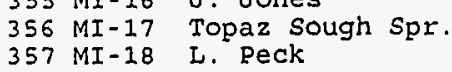

$358 \mathrm{MI}-19$ Petersen

$359 \mathrm{MI}-20$ L. Ellsworth

$360 \mathrm{MI}-20 \mathrm{~L}$. Ellsworth

361 MI-2I unnamed

$362 \mathrm{MI}-22$ Coyote Spr. (BLM)

363 MI-22 Coyote Spr. (BLM)

$364 \mathrm{MI}-23$ unnamed

$365 \mathrm{MI}-24$ Footes Ranch

366 MI-25 Twin Spr.

367 MI-25 Twin Spr.

368 MI-26 O. Levanger

$\begin{array}{lll}369 & \text { MI }-27 & \text { Gardner } \\ 370 & \text { MI }-28 & \text { R. Moody }\end{array}$

371 MI-29 T. Larsen
TP

LOCATION

(C-14-04) $32 \mathrm{dbd}$

(C-14-08) 10dca

(C-14-08) 10dca

$(\mathrm{C}-14-08) 10 \mathrm{dca}$

$(C-14-08) 10 \mathrm{dca}$
$(\mathrm{C}-14-08) 10 \mathrm{dca}$

(C-14-08) 10dca

(C-14-08) $13 \mathrm{dcc}$

(C-14-12) 04cbc

(D-13-01) 17bdd

(C-40-09) 36ccb

(C-44-05) $06 \mathrm{cbb}$

$(\mathrm{D}-39-03) 35 \mathrm{ccc}$

(C-43-05) 02bbd

(c-16-07) $24 \mathrm{dc}$

(C-16-08) $26 \mathrm{db}$

$(\mathrm{c}-10-07) 22 \mathrm{bcd}$
$(\mathrm{C}-13-06) 09 \mathrm{bcc}$

(c-15-04)20caa

(c-15-05) 27dcc

(C-15-05) $33 \mathrm{dcb}$

(C-15-08) 08cac

(C-15-19) $31 \mathrm{dc}$

(C-15-19) 31dc

(C-16-05) 09aaa

(C-16-05) 18caa

(C-16-05) $18 \mathrm{caa}$

(C-16-05) $19 \mathrm{cbd}$

(C-16-06) $27 \mathrm{aaa}$

(c-16-06) 34 bad

(C-16-07) $23 \mathrm{ba}$

(c-16-07) $24 \mathrm{bca}$

(c-16-08) 06 cab

(C-16-08) $12 \mathrm{bb}$

(C-16-08) $15 \mathrm{cad}$

(C-16-08) $21 d c$

(c-16-08) 26bdb

(C-16-15) $13 \mathrm{bab}$

(C-16-15) $13 \mathrm{bab}$

(C-16-15) $26 \mathrm{cab}$

(C-16-18) $09 \mathrm{~cd}$

(C-16-18) 22 cab

(c-16-18) 22 cab

(c-17-06) $17 \mathrm{aaa}$

$W \quad(C-17-06) 18 d b$
$W \quad(C-17-06) 21 d b$
LATITUDE LONGITUDE UTM.N UTM.E

$\begin{array}{llll} & 12.3142 & 4379261 \quad 387095\end{array}$

$\begin{array}{lllll}30.6133 & 112.7283 & 4386483 & 350811\end{array}$

$\begin{array}{llll}39.6125 & 112.7281 & 4385967 & 351651\end{array}$

$39.6133 \quad 312.72834386483 \quad 350811$

$9.6133 \quad 112.72834386483 \quad 350811$

$\begin{array}{llll}39.5958 & 112.6953 & 4384060 & 354432\end{array}$

$\begin{array}{llll}39.5958 & 112.6953 & 4384060 & 354432\end{array}$

$\begin{array}{llll}39.6292 & 113.2083 & 4388724 & 310471\end{array}$

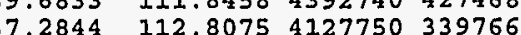

$\begin{array}{llll}37.2333 & 112.8750 & 4122197 & 333669\end{array}$

$7.0339 \quad 112.46254097211369889$

$\begin{array}{llll}37.3703 & 111.5600 & 4135895 & 450415\end{array}$

$\begin{array}{lll} & \end{array}$

$39.4170 \quad 112.59104364052363038$ $\begin{array}{llll}4030 & 112.7200 & 4362702 & 351903\end{array}$ $9.9417 \quad 112.6261 \quad 4422342 \quad 361072$ 39.7064 112.5333 4396086368553 (12.31939 43731982 380237 (1) (112.4150 4369526378279 (112.7747 4394214347812 $\begin{array}{lllll}4708 & 113.9917 & 4373088 & 242640\end{array}$ $\begin{array}{llll}4708 & 113.9917 & 4373088 & 242640\end{array}$ \begin{tabular}{l}
$113.9917 \quad 4373088 \quad 242640$ \\
\hline
\end{tabular} \begin{tabular}{l}
$112.4072 \quad 4367329 \quad 378916$ \\
\hline
\end{tabular} $9.4272 \quad 112.4506 \quad 4364980375143$ $\begin{array}{llll}39.4119 & 112.4506 & 4364980 & 375143\end{array}$ $\begin{array}{llll}39.4119 & 112.4586 & 4363293 & 374427\end{array}$ $\begin{array}{lll}39.4022 & 112.5014 \quad 4362277 \quad 370724\end{array}$ $\begin{array}{lllll}39.3861 & 112.5111 & 4360504 & 369859\end{array}$ $\begin{array}{llll} & & & \end{array}$ $\begin{array}{llll}4125 & 112.5922 \quad 4363554 \quad 362926\end{array}$ $\begin{array}{llll} & \end{array}$ $39.4219 \quad 112.7367 \quad 4364827 \quad 350505$ $\begin{array}{llll} & 4160 \quad 112.7630 & 4364216 \quad 348228\end{array}$ $\begin{array}{lllll} & 4150 \quad 112.7630 & 4364105 \quad 348226\end{array}$ $\begin{array}{llll} & \end{array}$ $\begin{array}{lll} & \end{array}$ . $4242 \quad 113.4858 \quad 4366592 \quad 286023$ .38 113.50804362627284000 $\begin{array}{llll}9.4320 & 113.8750 & 4368454 & 252543\end{array}$ . $.4380113 .8500 \quad 4424556 \quad 256481$ $\begin{array}{lllll}39.3603 & 112.5589 & 4357711 & 365693\end{array}$ $\begin{array}{llll}39.3453 & 112.5381 & 4356015 & 367456\end{array}$ $39.3760 \quad 112.53204359414 \quad 368040$

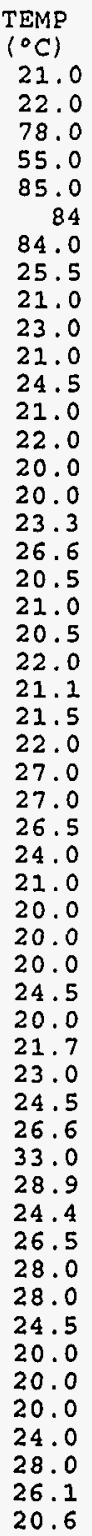

DEPTH STA FLOW

168.6

168.6

168.6

1200.0

168.6

$155.1 \mathrm{p}$

$27.4 \mathrm{P}$

$281.9 \mathrm{P}$

75.7
151.4

151.4
8.7

35.6

$261.0 \quad 5186.0$

$257.0 \quad 5262.0$

45.7

304.8 P 9842.1

365.8 P 19797.7

$\begin{array}{lll}90.1 & P & 23280.3\end{array}$

17.5

17034.0

194.2 p 22144.7

$179.8 \mathrm{P} \quad 19873.4$

$285.0 \quad 12113.0$

253.0

253.0

365.8 P 7571.0

$\begin{array}{lr}114.9 \mathrm{p} & 56.8\end{array}$

91.0

260.6

5299.6

$291.0 \quad 6549.0$

$6 \mathrm{P} \quad 8555.0$

$304.0 \quad 3956.0$

1438.5
379.0

3785.0

F $\quad 3974.7$

57.9 P $\quad 136.3$

256.0

250.0

128.0

34.0
LEVEL

52.1 WATSTORE

52.1 WATSTORE

WATSTORE

WATSTORE

Mariner and others, 1983

this study

Cole, 1983

WATSTORE

WATSTORE

112.8 WATSTORE
WATSTORE

WATSTORE

WATSTORE

ATSTORE

TATSTORE

Mower and Feltis, 1964 Mower and Feltis, 1964

WATSTORE

WATSTORE

Wower and Feltis, 1964

WATSTORE

Mundorff, 1970

(1970

WATSTORE

Mower and Feltis, 1964

7.1 WATSTORE

Mower and Feltis, 1964 33.5 WATSTORE

Mower and Feltis, 1964

-1.1 WATSTORE

Mower and Feltis, 1964

4.3 WATSTORE

Mower and Feltis, 1964 Mower and Feltis, 1964

WATSTORE

Stephens, 1977

Stephens, 1977

Meinzer, 1911

WATSTORE

9.1 WATSTORE

WATSTORE

Mower and Feltis, 1964
Mower and Feltis, 1964 
ID MAP NO. SOURCE NAME

$372 \mathrm{MI}-30$ L. Ellsworth

$373 \mathrm{MI}-31$ unnamed

$374 \mathrm{MI}-32$ P. Theobald

$\begin{array}{lll}375 & M I-32 & \text { P. Theo } \\ 376 & M I-33 & \text { C. Cox }\end{array}$

$377 \mathrm{MI}-34$ C. ROss

$378 \mathrm{MI}-35$ Town of Delta

$379 \mathrm{MI}-35$ Town of Delta

$380 \mathrm{MI}-36$ Town of Delta

381 MI-37 LDS Church

$382 \mathrm{MI}-38$ G. Petexson

$383 \mathrm{MI}-39$ unnamed

$385 \mathrm{MI}-40$ unnamed

$386 \mathrm{MI}-41$ Tule Spx. north

$387 \mathrm{MI}-42$ Tule Spr. south

$388 \mathrm{MI}-43$ unnamed

$389 \mathrm{MI}-44$ unnamed

$390 \mathrm{MI}-45$ Union Pacific

$391 \mathrm{MI}-46$ C. Haxt

$393 \mathrm{MI}-47$ W. Robison

$394 \mathrm{MI}-47$ W. Robison

$395 \mathrm{MI}-47$ W. Robison

396 MI-48 Knoll Spr

$398 \mathrm{MI}-50 \mathrm{~J}$. Hil

399 MI-5I J. Hill

$400 \mathrm{MI}-52$ W. Tuttle

401 MI-53 Coats Farms

402 MI-54 Valley Farm Inc.

403 MI-55 Triple C Farms

$404 \mathrm{MI}-56$ Triple C Farms

405 MI-57 Triple C Fa

$407 \mathrm{MI}-59$ Bureau of Land Mgmt.

$408 \mathrm{MI}-59$ Bureau of Land Mgmt.

$409 \mathrm{MI}-60$ unnamed

410 MI-61 E. Wilson

411 MI-62 Christensen Bros.

$412 M I-63$ N. MCBride

413 MI-64 stott L. \& I. Co.

$414 \mathrm{MI}-65$ Neels railroad

$415 \mathrm{MI}-66$ unnamed

416 MI-67 Swallow \& Sons

417 MI-68 J.S. Anderson \& Sons

418 MI-69 Utley and Starley

419 MI-70 I. Christensen

$420 \mathrm{MI}-71$ V. Rasmussen

121 MI-72 W. Paxton

122 MI-73 Continental Lime Inc.

$\begin{array}{lll}423 & \text { MI-74 } & \text { unnamed } \\ 424 & M I-75 & E \text {. Woodbury }\end{array}$
TP IOCATION

W $(\mathrm{C}-17-06) 26 \mathrm{ba}$

AATITUDE LONGITUDE UTM.N UTM.E (C-17-06)26daa $39.3089 \quad 112.48224351895 \quad 372207$ (c) (C-17-06) 2900 39.3125 112.52864352361368214 (C-17-05)33do 39.2950112 .53704350431367456 (C-17-07)01bb 39.3580112 .57704356595364113 (C-17-07) 01bb $39.3500 \quad 112.57704356595364113$ (c-17-07)01dda $39.3600 \quad 112.57674357704364158$ (C-17-07)26c3c $39.3067 \quad 122.60694351835361451$ (c-17-07) $34 \mathrm{cb} 39.2890 \quad 112.62704349901359683$ (c-17-08) 11bbc $39.3572 \quad 112.72534357627351349$ (C-17-15)10aa $39.3520 \quad 113.51304358655283027$ (c-17-15)10aab $39.3514 \quad 113.51444358580283335$ s (C-17-15) 10ad $39.3515 \quad 113.51604358595283198$ (C-17-15) 15ad $39.3330 \quad 133.53804356546282968$ (c-17-15) $25 \mathrm{~cd} \quad 39.3000 \quad 113.49004352816285281$ $(C-17-15) 25 d c$ (C-18-05) 06dd (C-18-06) 06aba (C-18-06) 06aba (C-18-08) 24 ada (c-18-08) 24 ada (C-18-08) 24ada (C-18-18) 16ad $(\mathrm{C}-18-19) 20 \mathrm{bb}$ (C-18-19) 20 ddd $(\mathrm{C}-18-19) 28 \mathrm{dd}$ $(\mathrm{C}-19-04) 17 \mathrm{cc}$ $(\mathrm{C}-19-04) 29 \mathrm{bcd}$ (C-19-05) 01abc $(C-19-05) 02 a d b$ (C-19-05) 11aad $(\mathrm{C}-19-05) 12 \mathrm{abc}$ $(\mathrm{C}-19-05) 21 \mathrm{cbb}$ $(\mathrm{C}-19-05) 31 \mathrm{~cd}$ $(\mathrm{C}-19-05) 31 \mathrm{~cd}$ $(\mathrm{c}-19-09) 29 \mathrm{cbc}$ W $(c-20-05) 21 \mathrm{bc}$ $W \quad(C-20-05) 32$

W $(C-20-05) 32 \mathrm{db}$ W (C-20-05) 33 bda W (C-20-20) $12 a c c$ W $(C-21-05) 05 \mathrm{dbc}$ (c-21-05) $29 \mathrm{cbc}$ (C-21-05) $30 \mathrm{ba}$ W $(\mathrm{C}-21-05) 30 \mathrm{dbc}$ W (C-21-05) $32 \mathrm{bba}$ W $(\mathrm{C}-21-06) 09 \mathrm{ca}$ $W ?(C-22-04) 08 d d b$ $W(C-22-05) 09 \mathrm{cad}$ $39.3000 \quad 113.4900 \quad 4352816285281$ $39.2850 \quad 112.4590 \quad 4349210 \quad 374165$ $\begin{array}{lllll}39.2860 & 112.5620 & 4349469 & 365283\end{array}$ $\begin{array}{lllll}39.2861 & 112.5631 & 4349482 \quad 365188\end{array}$ $\begin{array}{lllll}39.2389 & 112.6889 & 4344439 & 354240\end{array}$ $\begin{array}{lllll}39.2389 & 112.6889 & 4344439 & 354240\end{array}$ $\begin{array}{lllll}39.2389 & 112.6889 & 4344439 & 354240\end{array}$ $39.4850 \quad 114.0020 \quad 437469424180$ $39.2233 \quad 114.0000 \quad 4345638 \quad 243013$ (1).2230 114.00104345608240925 $39.1550 \quad 112.3328 \quad 4334615 \quad 384838$ $\begin{array}{lllll}39.1328 & 112.3294 & 4332147 & 385095\end{array}$ $\begin{array}{lllll}39.1958 & 112.3578 \quad 4339175 & 382745\end{array}$ $39.1939 \quad 112.3744 \quad 4338986381308$ $39.1814 \quad 112.3728 \quad 4337596 \quad 381426$ $\begin{array}{lllll}39.1786 & 112.3667 & 4337278 & 381948\end{array}$ $39.1475 \quad 112.42674333906376711$ $39.1200 \quad 112.4710 \quad 4330915 \quad 372833$ $39.1200 \quad 112.47104330915372833$ $39.0520 \quad 112.89394332392336288$ $39.0280 \quad 112.43904323324 \quad 375480$ $39.0330 \quad 112.43804321214 \quad 375533$ $\begin{array}{llll}39.0339 & 112.4189 & 4321288 \quad 37718\end{array}$ $\begin{array}{lllll}39.0500 & 112.7680 & 4323604 & 34700\end{array}$ $39.0833 \quad 114.0458 \quad 4330230 \quad 236536$ $39.0122 \quad 112.43724318905 \quad 375566$ $\begin{array}{lllll}38.9539 & 112.4464 & 4312448 & 374666\end{array}$ $\begin{array}{llll}38.9570 & 112.4500 & 4312797374360\end{array}$ $\begin{array}{llll}38.9489 & 112.4533 & 4312490 & 374069 \\ 38.4419 & 4311887 & 375048\end{array}$ $\begin{array}{lllll}38.9980 & 112.5290 & 4317459 & 367591\end{array}$ $\begin{array}{llll}38.9394 & 112.8161 \quad 4311412 \quad 34259\end{array}$ $38.9058 \quad 112.32194306946 \quad 385378$ 112.42064307607376827

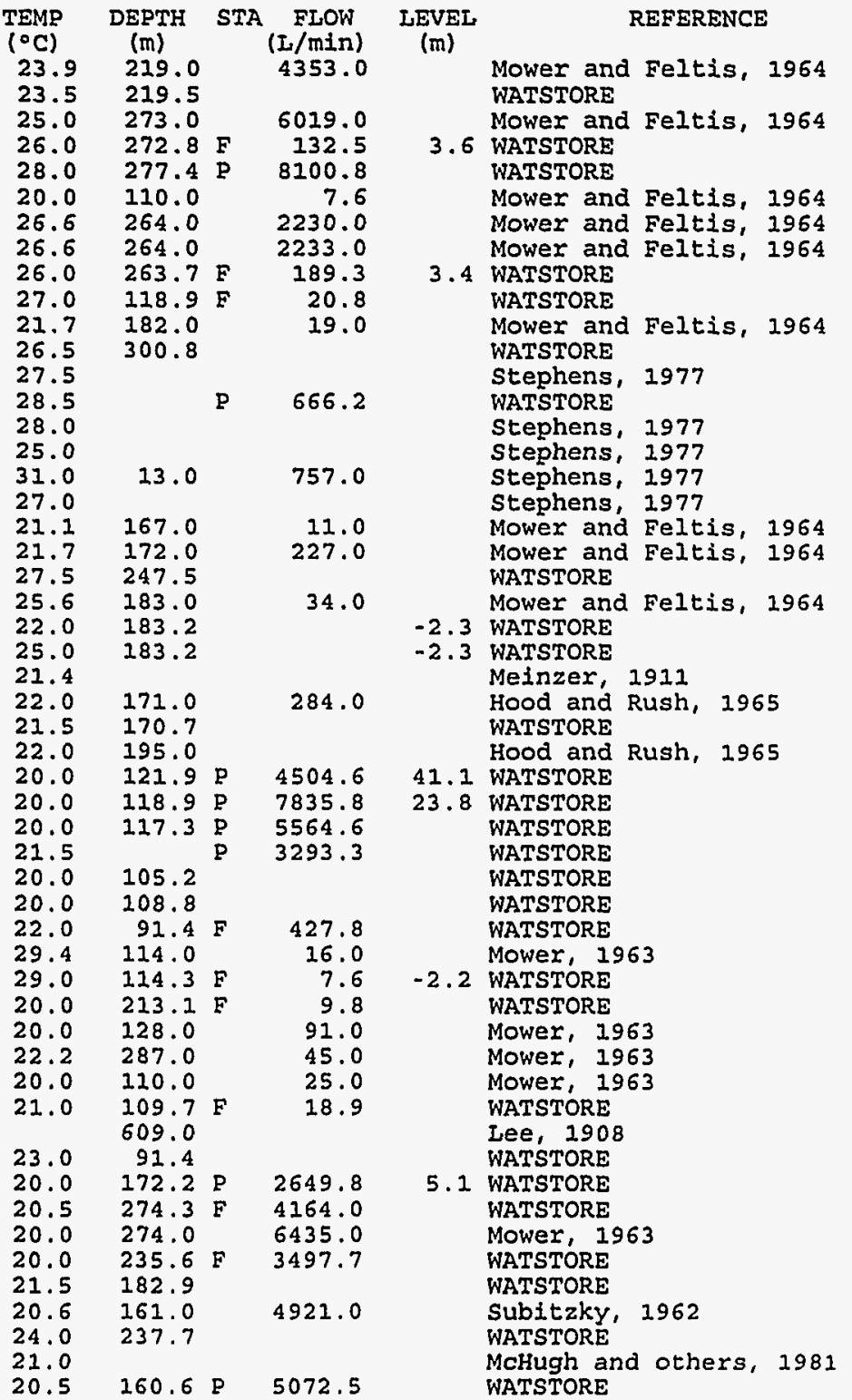


ID MAP NO. SOURCE NAME

$425 \mathrm{MI}-76$ unnamed

426 MI -77 unnamed 428 MI -79 unnamed

429 MI-80 Meadow Hot Spr. E $430 \mathrm{MI}-80$ Meadow hot Spr. E. 431 MI-8I Meadow Hot Spr. W. 432 MI-81 Meadow Hot Spr. W. 433 MI-81 Meadow Hot Spr. W. 434 MI-81 Meadow Hot Spr. $W$. 435 MI-81 Meadow Hot Spr. $W$. 436 MI-82 Meadow hot Spr. S.

437 MI-83 Hatton Hot Weli

438 MI-84 Hatton Hot Spr.

439 MI-84 Hatton Hot Spr.

$440 \mathrm{MI}-84$
$441 \mathrm{MI}-85$
Fed. Int. Cred Ban

$\begin{array}{lll}442 & \text { MI-86 } & \text { unnamed } \\ 443 & \text { MI-87 } & \text { Twin Peaks spr. }\end{array}$

444 MI-87 Twin Peaks Spr.

445 MI-87 Twin Peaks Spr.

446 MI-87 Twin Peaks Spr.

$447 \mathrm{MI}-88$ unnamed

448 MI-89 Coyote Spr. (north)

449 MI-90 Cudahy (mine ?

450 MI-91 Black Spr.

451 MI-92 unnamed

453 MI-94 Coyote Spr.

$454 \mathrm{MI}-95$ unnamed

454 MI-95 unnamed

$456 \mathrm{MI}-97$ Utah State $31-33$

$457 \mathrm{MI}-98$ unnamed

458 MI-99 unnamed

459 MI- 100 unnamed

460 MO-01 Como Warm Sp

462 PI-02 unnamed

463 PI-03 G. Moore

464 PI-04 Utah Parks \& Rec.

465 SA-01 FBC IrI.

$\begin{array}{lll}466 & S A-02 & \text { K. Timms } \\ 467 & \text { SA-03 } & \text { J. Paulsen }\end{array}$

468 SA -04

469 SA-05

$\begin{array}{ll}470 & \text { SA }-06 \\ 471 & \text { SA }-06\end{array}$

472 SA-07

473 SE-01

474 SE-02 Richfield Wm Spr.

$\begin{array}{ll}475 & \text { SE-02 Richfield } \\ 476 & \text { SE-03 unnamed }\end{array}$

477 SE-04 Monroe Hot Spr. $\begin{array}{llllll}\text { W? } & (\mathrm{C}-22-05) 26 \mathrm{cdd} & 38.8617 & 112.3842 & 4302132 & 379901 \\ \mathrm{~S} & (\mathrm{C}-22-06) 00 & 38.8630 & 112.5070 & 4302445 & 369248\end{array}$

LATITUDE LONGITUDE UTM.

UTM.E

$\left({ }^{\circ} \mathrm{C}\right)$

DEPTH

(L/min)

LEVEL

REFERENCE (c-22-06) $25 \mathrm{~cd} \quad 38.8720 \quad 112.4820 \quad 4303408371434$ $(\mathrm{C}-22.06) 25 \mathrm{ca} \quad 38.8690 \quad 112.48404303078371255$ $(\mathrm{C}-22-06) 26 \mathrm{CCC} 38.8647 \quad 112.50194302627369694$ (C-22-06) 26ccc 38.8647 112.5019 4302627369694 (C-22-06) 27 dde 38.8639 112.5069 4302545369259 (C-22-06)27dde 38.8639 112.5069 4302545369259 (c-22-06)27dde $38.8639 \quad 112.50694302545369259$ (c-22-06) 27ddd 38.8639 112.5069 4302545369259 (c-22-06)27ddc $38.8639 \quad 112.50694302545369259$ $\begin{array}{lllll}(\mathrm{C}-22-06) 34 & 38.8605 & 112.5098 & 4302175 & 369000\end{array}$ $(C-22-06) 35 b b \quad 38.8480 \quad 112.48904300755370783$ $(C-22-06) 35 d d b \quad 38.8500 \quad 112.4900 \quad 4300978 \quad 370700$ $(\mathrm{C}-22-06) 35 \mathrm{ddb} \quad 38.8500 \quad 112.49004300978 \quad 370700$ (C-22-06) 35dab $38.8500 \quad 112.49004300978 \quad 370700$ (C-23-06) lobdd $38.8264 \quad 112.51394298393368582$ (c-23-06) 31bcc $38.7675 \quad 112.57894291953 \quad 362827$ $(c-23-08) 23 \mathrm{dbb} 38.7960 \quad 112.71504295328351061$ $(c-23-08) 23 \mathrm{dbb} 38.7960 \quad 112.71504295328351061$ (C-23-08) $23 \mathrm{dbb} 38.7960 \quad 112.7150429528351061$

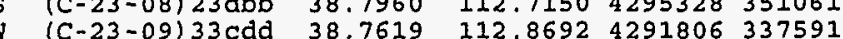
$(\mathrm{C}-23-09) 33 \mathrm{db} \quad 38.7730 \quad 122.86504293031337981$ (C-23-09)35acc $38.7694 \quad 112.83144292573 \quad 340879$ $(C-23-09) 35 \mathrm{dbb} \quad 38.7697 \quad 112.83114292605 \quad 340919$ S? $(C-24-04) 11$ ace $38.7289 \quad 112.20894287179 \quad 394917$ $S ?(C-24-05) 21 d c b \quad 38.6908 \quad 112.4633 \quad 4283274 \quad 372734$ S $\quad(C-24-09) 04 d d \quad 38.7620 \quad 112.8750 \quad 4291828 \quad 337087$ W (C-24-12) $15 \mathrm{cdc} \quad 38.7183 \quad 113.1906 \quad 4287587309547$

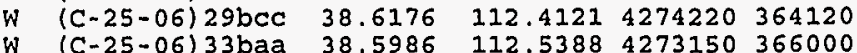
$\mathrm{S} \quad(\mathrm{C}-25-06) 33 \mathrm{bcb} \quad 38.5939 \quad 112.54314272630365609$ W) $(\mathrm{C}-25-07) 14 \mathrm{bd} \quad 38.6369 \quad 112.60924277505359940$ W (C-25-07) 26bda $38.6070 \quad 112.60894274190359910$ $S \quad(A-04-03) 31 \mathrm{cab} \quad 41.0390 \quad 111.6540 \quad 4543080 \quad 445028$ $M \quad(C-27-4.5) 28 a a \quad 38.4386 \quad 112.3117 \quad 4255088 \quad 385520$ $S \quad(C-28-2.5) 26 a C \quad 38.3481 \quad 112.0886 \quad 4244793 \quad 404874$ $w(C-29-02) 35 \mathrm{bad} \quad 38.2444 \quad 111.9778 \quad 4233178 \quad 414434$ $w \quad(\mathrm{C}-30-02) 28 \mathrm{bdc} \quad 38.1675 \quad 112.0175 \quad 4224683 \quad 410866$ W (D-14-05) 16bdd $39.6017 \quad 111.3670 \quad 4383329468491$ W $\quad(D-15-03) 14 \mathrm{bdb} \quad 39.5147 \quad 111.5575 \quad 4373835 \quad 452075$ W (D-17-03) 03dbd $39.3628 \quad 111.5653 \quad 4356982451299$ $S \quad(D-18-02) 13$ cad $39.2458 \quad 111.6450 \quad 4344288444342$ $S \quad(D-18-02) 14 \mathrm{CdC} \quad 39.2417 \quad 111.66614343602442516$ $S \quad(D-19-02) 04 d c a \quad 39.1828 \quad 111.6907 \quad 4337104 \quad 440318$ $S \quad(D-19-02) 04 d C a \quad 39.1828 \quad 111.6907 \quad 4337104440318$ $S$ (D-19-06) 06aad $39.2019 \quad 111.28174339011475676$ W (C-21-01) 11ada $38.9967 \quad 111.8708 \quad 4316705 \quad 424834$ S $\quad(C-23-03) 26 a C \quad 38.7738 \quad 212.0957 \quad 4292395404621$ $S \quad(C-23-03) 26 a c \quad 38.7738 \quad 112.0957 \quad 4292395404621$ $\begin{array}{llllll}S ? & (C-24-03) 08 d d b & 38.7217 & 112.1497 & 4286314 & 400053 \\ S & (C-25-03) 10 d d a & 38.6330 & 112.1070 & 4276536 & 403647\end{array}$
35.0 24.0 22.0 41.0 41.0 29.0 31.5 41.0 41.0 29.0 34.0 67.0 37.7
66.0 63.0 21.5 21.0 25.0 25.0 31.0 28.0 23.5 32.0 20.5 20.5 21.0 20.0 23.5 91.0 146.0 33.9
20.0 20.0 25.0 22.0 21.0 $55.0 \quad 2776.0$ $\begin{array}{rr}33.0 & 6492.3 \\ 38.0 & 182.9\end{array}$ 22.2 22.0 20.0 19.4 21.5 21.1 22.2 21.0 70.0

27.0

40.2
132.0

Mcrugh and others, 1981 Dennis and others, 1946

\section{WATSTORE}

Ross and others, 1993 WATSTORE

WATSTORE

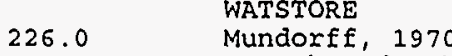

McHugh and others, 198 Ross and others, 1993

Rush, 1977

Mundorff, 1970

14.4 MATSTORE

Mabey and Budding, 1987

McHugh and others, 1981 McHugh and others, 1981 WATSTORE

Parry and cleary, 1978 Cole, 1983

Mchugh and others, 1981 Parry and Cleary, 1978

Mctugh and others, 1981 Mctugh and others, 2981 Parry and

\section{$\begin{array}{llll}162.2 \mathrm{P} & 113.6 & 27.6\end{array}$}

1591.0

75.7

A.sh and others, 1979

Ash and others, 1979

Union Oil Company, 1978

$400.0 \mathrm{P}$

34068.0

Mchugh and others, 198

Mundorff, 1970

McHugh and others, 1981

McHugh and others, 1981

6.7 WATSTORE

$1109.0 \quad$ Robinson, 1968

-240.8 WATSTORE
-0.9 WATSTORE

Mundorff, 1970

WATSTORE

Mundorff, 1970

Robinson, 1968

$\begin{array}{rr}13.0^{F} \quad 0.8 \\ & 45.4 \\ & 5299.0\end{array}$

5299.0
2650.0

541.0
Carplong, 1963

Mundorff, 1970

Mundorff, 1970

McHugh and others, 1981
Cole, 1983 
ID MAP NO.

478 SE-05 Red Hill Hot Spr.

479 SE-05 Red Hill Hot Spr.

480 SE-06 Johnson Warm Spr.

481 SE-07 $E$. Mecham

482 SE-08 Joseph Hot Spr.

483 SE-09 unnamed

$484 \mathrm{SE}-10$ unnamed

485 SJ-01 Narm Spr.

486 SJ-02 Wexpro Co. W

488 SJ-04 Energy Fuels Nuc. Inc.W

489 SJ-05 Energy Fuels Nuc. Inc.W

490 SJ-06 National Park Service $W$

491 SJ-07 National Park Service $W$

492 SJ-08 BIA 12R-163

493 SJ-09 City of Bluff

$\begin{array}{lll}494 & \text { SJ-10 } & \text { City of Bluff } \\ 495 & \text { SJ-10 } & \text { City of Bluff }\end{array}$

$496 \mathrm{SJ}-11$ Bureau of Land Mgmt.

497 SJ-12 Texaco

498 SJ -13 Texaco

$499 \mathrm{SJ}-14$ unnamed

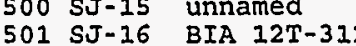

502 SJ-17 BIA 12R-173

503 SJ-18 Texaco

S04 SJ-19 unnamed

505 SJ-20 unnamed

507 SJ-22 Navajo Tribe

508 SJ-23 BIA 8A-293

509 SJ -24 BIA $2 A-104$

510 SJ-25 BIA 8A-28I

511 SJ-26 BIA 8A-229

512 SJ-27 BIA 8A-260

513 SJ-28 Navajo Tribe

514 SJ-29 BIA 9 Y -57

516 SL-01 C. \& G. Gillmore

517 SL-02

518 SL-03 Becks Hot Spr.

519 SL-03 Becks Hot Spr.

S20 SL-03 Becks Hot Spr.

521 SL-03 Becks Hot Spr.

522 SL-04 Hob

524 SL-06 Wasatch Plunge Inc.

525 SL-06 Wasatch Hot Spr.

526 SL-06 Wasatch Hot Spr.

527 SL -07 G

528 SL 08 unnamed

530 SL-08 unnamed
LATITUDE LONGITUDE UTM.N UTM

(C-25-03) 11cad $38.6378 \quad 112.09924276950404331$ $S \quad(C-25-03)$ licad $38.6378 \quad 112.0992 \quad 4276950404331$ $S \quad(C-25-03) 27 a d \quad 38.6030 \quad 112.11104273112402300$ (C-25-04)13cbe $38.6210 \quad 112.19704275192 \quad 395795$ (C-25-04)23aac $38.6142 \quad 112.2010427453139543$ (D-21-05) 26bba $38.9678 \quad 111.33084313047471342$ $\begin{array}{llllll}(D-22-04) 32 \mathrm{dbb} & 38.8522 & 111.4864 & 4300280 & 457793\end{array}$ (D-36-26) 07bac $37.6764 \quad 109.10644171394666993$ $(D-37-22) 22 \mathrm{ccb} \quad 37.5500 \quad 309.49174156753633237$ $(D-37-22) 28 \mathrm{dbb} \quad 37.5383 \quad 109.5006 \quad 4155442 \quad 632472$ D-37-22) 33dda $37.5225 \quad 109.49474153697 \quad 633021$ (D-38-11) $29 \mathrm{Cda} \quad 37.4508 \quad 110.71894144716524863$ $\begin{array}{lllll}(\mathrm{D}-39-26) 21 \mathrm{db} & 37.3840 & 109.0670 & 4139021 & 671135 \\ (\mathrm{D}-39-26) 33 & 37.3530 & 109.0690 & 4135578 & 67102\end{array}$ (D-40-21) $25 a b a \quad 37.2881 \quad 109.5506 \quad 4127614 \quad 62848$ $(D-40-22) 30 \mathrm{bbb} \quad 37.2878 \quad 109.5486 \quad 4127583 \quad 528658$ $(\mathrm{D}-40-22) 30 \mathrm{bbb} \quad 37.2878 \quad 109.5486 \quad 4127583 \quad 62865$ (D-40-23) 27baa $37.2725 \quad 109.3528 \quad 4126170646046$ (D-40-24) 15bcc $37.3114 \quad 109.2728 \quad 4130613653060$ (D-40-24) 17dbd $37.3083 \quad 109.29724130229650904$ (D-40-24) 17dca $37.3050 \quad 109.30114129857650565$ (D-40-24) 22adb $37.2975 \quad 109.26224129088654028$ (D-40-25) 01bcc $37.3385 \quad 109.1468 \quad 4133807 \quad 665746$ $(\mathrm{D}-40-25) 05 \mathrm{bbb} \quad 37.3440 \quad 109.20334134342659001$ (D-40-26) 19ade $37.2967 \quad 109.09694129281668683$ $(D-40-26)$ 20aad $37.2653 \quad 109.08114125825670154$ (D-41-24) 21bb $37.2147 \quad 109.29534119848651260$ $(D-41-25) 04 \mathrm{Cad} 37.2492 \quad 109.17894123868661515$ $(D-41-25) 12$ dac $(D-42-16) 19$ $(D-42-09) 35$ $(\mathrm{D}-42-17) 14$ $(D-43-16) 23$ (D-43-19) 29 $(D-43-23) 15 \mathrm{cab}$ $(D-43-23) 32$ $\begin{array}{lll}37.2347 & 109.1167 & 4122367 \quad 667064\end{array}$

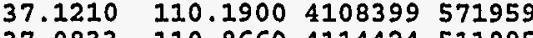
$\begin{array}{llll}37.0833 & 110.8660 & 4114424 & 511895\end{array}$ $37.1360 \quad 110.0080 \quad 4110216 \quad 588110$ $37.0340 \quad 110.11804098805 \quad 578445$ $37.0200 \quad 109.71604097658 \quad 614221$

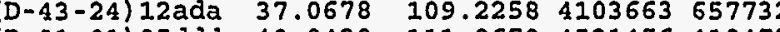
(B-01-01) osddd 40.8420 111.9670 4521456 418477 (B-01-01) 05ddd 40.8431 111.9689 4521580418318 (B-01-01) 14dcb $40.8158 \quad 111.91814518503422569$ (B-01-01) 14dab $40.8158 \quad 111.91814518503 \quad 422569$ (B-01-01) 14acb $40.8158 \quad 111.91814518503422569$ (B-01-01) 14dab $40.8158 \quad 111.91814518503422569$ $(B-01-01) 23 a c c \quad 40.8067$ 111.9181 4517493422559 (B-01-01) 23bda 40.8060 111.9180 4517415422566 (B-01-01) 25dbd 40.7900 111.8998 4511787 424688 B-01-01) 25dbd 40.7900 111.8998 4511787424688 B-01-01) 25dbd 40.7900 111.898 4511787 424688 (B-01-02) 02 ac (B-01-02) 02dac 40.8464 $\begin{array}{llllll}B-01-02) 02 \text { dac } 40.8464 & 112.0286 & 4522004 & 413290\end{array}$

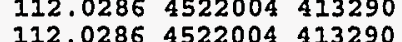

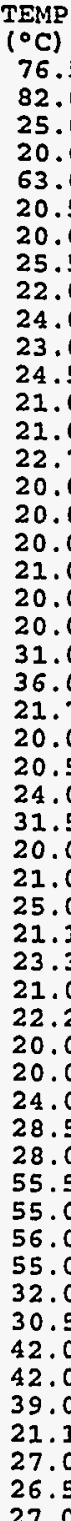

\begin{tabular}{|c|c|c|c|c|}
\hline \multirow{3}{*}{$\begin{array}{l}\text { DEPTH } \\
(m)\end{array}$} & STA & $\begin{array}{l}\text { FLOW } \\
\text { (I/min })\end{array}$ & $\begin{array}{l}\text { LEVEL } \\
\text { (m) }\end{array}$ & REFERENCE \\
\hline & & 541.0 & & $\begin{array}{l}\text { Cole, } 1983 \\
\text { Mciugh and others, } 2981\end{array}$ \\
\hline & & 37.9 & & Mundorff, 1970 \\
\hline \multirow[t]{4}{*}{22.0} & & $\begin{array}{r}19.0 \\
121.0\end{array}$ & & $\begin{array}{l}\text { Carpenter and Young, } 196 \\
\text { Cole, } 1983\end{array}$ \\
\hline & F & 0.9 & & WATSTORE \\
\hline & $F$ & 0.9 & & WATSTORE \\
\hline & & 189.0 & & Feltis, 1966 \\
\hline \multirow{5}{*}{$\begin{array}{l}573.0 \\
554.7 \\
573.0 \\
615.7 \\
320.0 \\
434.0\end{array}$} & $\underline{P}$ & 26.5 & 487.7 & WATSTORE \\
\hline & $\mathbf{P}$ & 900.9 & 140.2 & $\begin{array}{l}\text { WATSTORE } \\
\text { WATSTORE }\end{array}$ \\
\hline & P & 821.4 & 131.2 & WATSTORE \\
\hline & & 75.7 & 109.7 & WATSTORE \\
\hline & & 110.0 & & $\begin{array}{l}\text { Feltis, } 1966 \\
\text { Feltis, } 1966\end{array}$ \\
\hline \multirow{7}{*}{$\begin{array}{l}251.5 \\
251.5 \\
366.0 \\
204.8 \\
335.3 \\
281.9\end{array}$} & F & 14.0 & & WATSTORE \\
\hline & F & 227.1 & & WATSTORE \\
\hline & & 83.0 & & Feltis, 1966 \\
\hline & $\mathbf{F}$ & 329.3 & & WATSTORE \\
\hline & $\mathbf{P}$ & 321.8 & & WATSTORE \\
\hline & P & 495.9 & & WATSTORE \\
\hline & & & & $\begin{array}{l}\text { WATSTORE } \\
\text { WATSTORE }\end{array}$ \\
\hline \multirow[t]{2}{*}{427.0} & & 7.6 & & Feltis, 1966 \\
\hline & & 0.4 & & Feltis, 1966 \\
\hline \multirow[t]{2}{*}{237.4} & P & 677.6 & & WATSTORE \\
\hline & & & & $\begin{array}{l}\text { WATSTORE } \\
\text { WATSTORE }\end{array}$ \\
\hline \multirow{6}{*}{$\begin{array}{l}335.3 \\
219.5\end{array}$} & F & 33.3 & & WATSTORE \\
\hline & F & 0.4 & & WATSTORE \\
\hline & & & & Feltis, 1966 \\
\hline & & $\begin{array}{r}40.0 \\
7.6\end{array}$ & & $\begin{array}{l}\text { Feltis, } 1966 \\
\text { Feltis, } 1966\end{array}$ \\
\hline & & & & Feltis, 1966 \\
\hline & & 15.0 & & Feltis, 1966 \\
\hline \multirow[t]{6}{*}{154.8} & P & $\begin{array}{r}12.5 \\
1.9\end{array}$ & 42.5 & $\begin{array}{l}\text { WATSTORE } \\
\text { Feltis, } 1966 \\
\text { WATSTORE }\end{array}$ \\
\hline & & 454.0 & & $\begin{array}{l}\text { Marine, } 1960 \\
\text { Klauk, } 1984\end{array}$ \\
\hline & & & & Hely and others, 1968 \\
\hline & & & & Parry and Cleary, 1978 \\
\hline & & 870.0 & & $\begin{array}{l}\text { Cole, } 1983 \\
\text { Klauk, } 1984\end{array}$ \\
\hline & & & & Klauk, 1984 \\
\hline \multirow[t]{2}{*}{9.1} & & 379.0 & & Iorns and others, 1966 \\
\hline & & 240.0 & & $\begin{array}{l}\text { Hely and others, } 1967 \\
\text { Cole, } 1983\end{array}$ \\
\hline & & & & $\begin{array}{l}\text { Klauk, } 1984 \\
\text { Marine, } 1960\end{array}$ \\
\hline 134.1 & & & & $\begin{array}{l}\text { MaIIne, } 1960 \\
\text { WATSTORE }\end{array}$ \\
\hline & & & & WATSTORE \\
\hline
\end{tabular}


ID MAP NO. SOURCE NAME

531 SL-09 R. Irvine

532 SL-10 Lakefront Gun Club

$533 \mathrm{SL}-11$ unnamed

334 SL-12 Bonneville, Hill

535 SL-12 Bonneville, Hil

536 SL-12 Bonneville, Hill

537 SL-13 E. Jeremy

538 SL-14 unnamed

nnamed

540 SL-15 Bonneville, Hill

541 Si-16 unnamed

542 SL-17 C. Gillmore

543 SL-18 Bonneville, Hill

544 SL-19 unnamed

545 SL-20 KSL Radio \& Tele.

546 SL-21 unnamed

$\begin{array}{lll}547 & \text { SL }-21 & \text { unnamed } \\ 548 & \text { SL }-22 & \text { E. Jeremy }\end{array}$

548 SL-22 E. Jeremy

549 SL-23 unnamed

550 SL-24 U.S. Geol. Survey

551 Si-25 Granger Impvmt. Dist.

552 SL-26 Granger Impvmt. Dist.

553 SL-26 Granger Impvmt. Dist.

554 SL-27 unnamed

555 SL-28 Bonneville, Hill

556 SL-29 Bonneville, Hill

557 SL-29 Bonneville, Hili

558 SL-30 Bonneville, Hill

559 SL-31 Morton

560 SL-32 unnamed

562 SL-33 Div. Wildlife Res.

563 SL-34 Div. Wildlife Res.

564 SL-35 K. Young

565 SL-36 Kennecott Corp.

$566 \mathrm{SL}-38$ unnamed

568 SL 40 Bacchus Gravel Pit

568 SL-41 unnamed

$570 \mathrm{SL}-42$ unnamed

$\begin{array}{lll}570 & \text { SL-42 } & \text { unnamed } \\ 571 & \text { SL }-43 & \text { unnamed }\end{array}$

572 SL -44 unnamed

$\begin{array}{lll}572 & \mathrm{SL}-44 & \text { unnamed } \\ 573 & \mathrm{SL}-45 & \text { unnamed }\end{array}$

574 SL-46 State Prison

575 SL-47 Crystal Hot Springs

576 SL -48 State Prison

577 SL-49 unnamed

578 SL-50 unnamed

579 SL-51 State Forestry-1

580 SL-52 State Prison

581 SL-53 unnamed

$\begin{array}{lll}582 & \text { SL- } 54 & \text { unnamed } \\ 583 & S L-55 & \text { unnamed }\end{array}$ (B-01-02) 02dac $0.8462 \quad 111.9142 \quad 4521875 \quad 422933$

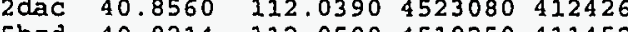
- $40.8214 \quad 212.05004519250411452$ (B-01-02) 16 caa $40.8189 \quad 112.07194518995409602$

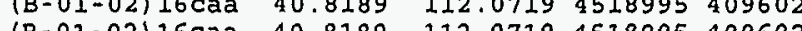
(B-01-02) 16 caa $40.8189 \quad 112.07194518995409602$ (B-01-02) 19aca $40.8081 \quad 112.1058 \quad 4517831 \quad 406728$ (B-01-02) 2lacd $40.8056 \quad 112.06784517514409930$ (B-01-02) 22bdb $40.8083 \quad 112.05724517803410828$ (B-01-02) 25Ca $40.7880 \quad 112.0150451550341082$ $\begin{array}{lllll}(B-01-02) 25 \mathrm{Ca} & 40.7880 & 112.0150 & 4515508 & 414361\end{array}$ (B-01-02) 25cda 40.7863 111.9020 4515218423893 (B-01-02) 28dad $40.7842 \quad 112.06334515134410281$ W (B-01-02)32bcb $40.7786 \quad 112.1000 \quad 4514551407176$ (B-01-02) $36 \mathrm{baa} 40.7831 \quad 112.01564514964414304$ (B-01-02)36baa $40.7831 \quad 112.0156 \quad 4514964 \quad 414304$

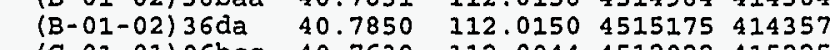
(C-01-01) 06bcc $40.7639 \quad 112.00444512822415225$ (c-01-01) l5cad 40.7308 111.9397 4509087420646 (C-01-01) (C-01-01) 33ddd 40.6825 111.9483 4503734419862 (C-01-01) 350a 40.6886 111.9483 4503734419862 (C-01-02) 01bad $40.7640 \quad 112.01604512844414246$ (C-01-02)02aba $40.7675 \quad 112.02924513246413236$ (C-01-02)02aba $40.7675 \quad 112.02924513246413136$ (C-01-02) 02ado $40.7620 \quad 112.02904512635413146$ (C-01-02)06aa $40.7681 \quad 112.10064513386407121$ (C-01-02)06aa $40.7685 \quad 112.10194513442407002$ (C-01-02)06aaa $40.7686 \quad 112.10194513442407002$ (c-01-02) 14cdd $40.7264 \quad 112.03504508689412593$ (C-01-02)14cdd $40.7264 \quad 112.03474508689412618$ (C-01-02)23cb $40.7110 \quad 112.03404506979412657$ (c-01-03) 15bca $40.7360 \quad 312.17504509904400784$ (C-02-01)03cdd $40.6681 \quad 111.93974502127420572$ W (C-02-01)25dac $40.6131 \quad 111.89424495982424356$ W (C-02-02) 05aa $40.6792 \quad 111.9703 \quad 4503384417996$ W $(\mathrm{C}-02-02) 24 \mathrm{bbb} \quad 40.6378 \quad 112.0233 \quad 4498843 \quad 413466$ $W \quad(C-03-01) 01 \mathrm{cbb} \quad 40.5867 \quad 111.9083 \quad 4493064 \quad 423133$ W (C-03-01) 02adc $40.5894 \quad 111.91364493368422687$ W $(\mathrm{C}-03-01) 08 \mathrm{bbc} \quad 40.5783 \quad 111.8708 \quad 4492099426297$ $w(C-03-01) 12 \mathrm{ccb} \quad 40.5689 \quad 111.90894491088423062$ $W \quad(\mathrm{C}-04-01) 02 \mathrm{bb} \quad 40.4960 \quad 111.9120 \quad 4482999 \quad 422716$ $S \quad(C-04-01) 11 / 12 \quad 40.4833 \quad 111.9108 \quad 4482438 \quad 423303$ W (C-04-01) l1ad $40.4884 \quad 111.90594482151423227$ W (C-04-01) 11adc $40.4856 \quad 111.91254481845422661$ W $(\mathrm{C}-04-01) 11 \mathrm{dab} \quad 40.4856 \quad 111.91674481849422305$ W (C-04-01) 12bbc $40.4898 \quad 111.90784482303423061$ W (C-04-01) 12bbd $40.4898 \quad 111.9070 \quad 4482303 \quad 423136$ W (C-04-01) 12bbd $40.4903 \quad 111.90564482361423251$ $\begin{array}{llllll}W & (C-04-01) 12 b c a & 40.4889 & 111.9067 & 4482206 & 423157 \\ W & (C-04-01) 12 b c a & 40.4894 & 111.9058 & 4482261 & 423233\end{array}$
DEPTH STA FLOW LEVEL

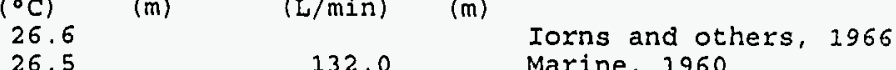

REFERENCE $20.0 \quad 91.4$ $\begin{array}{rr}24.0 & 193.9 \\ 22.5 & 193.9\end{array}$ -4.6 Marine, 1960 -6.1 WATSTORE -6.1 WATSTORE

26.2

182.9

170.7

188.0

75.6

141.4

141.0

4.9
236.2 $236.2 \mathrm{P}$ $270.1 P$
$270.1 \mathrm{P}$

126.0 $125.0 ?$ (3.0

138.0

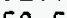

251.5

46.3

15.1

270.0

3438.0

$$
114.0
$$

36.0
251.0

202.0 -0.5 WATSTORE Klauk, 1984 -4.6 WATSTORE
-5.2 WATSTORE Marine, 1960

5.0 Iorns and others, 1966 Hely and others, 1967 Klauk, 1984

-2.7 WATSTORE

1.6 WATSTORE Klauk, 1984 Marine, 1960

1.2 WATSTORE WATSTORE

0.5 WATSTORE WATSTORE
Klauk, 1984

Hely and others, 1968 -2.5 WATSTORE

Hely and others, 1968 TATSTORE

WATSTORE WATSTORE

0.3 WATSTORE Marine, 1960 Iorns and others, 1966 Klauk, 1984 Marine, 1960 Klauk, 1984 Klauk, 1984 Klauk, 1984 Klauk, 1984 . 9 WATSTORE Marine, 1960 Cole, 1983 Klauk, 1984 Klauk, 1984

$154.0 \quad 1135.6 \quad$ Murphy and Gwynn, 1979 Utah Energy office, 1981 Klauk, 1984 Klauk, 1984
Klauk, 1984 
ID MAP NO. SOURCE NAME

584 SL-56 Camp Williams R.R. 585 SL-57 unnamed 586 SL-58 SL Valley $S \& G$ 587 SL-59 unnamed 588 SI-60 M. Schmidt

589 SL-61 unnamed

590 SL-62 unnamed

592 SL -64 unnamed

$593 \mathrm{SL}-65$ unnamed

594 SL-66 Draper Irrigation

595 SL-67 unnamed

596 SU-01 Town of Coalville

$597 \mathrm{SU}-02$ unnamed

598 SU-03 unnamed

600 T0-01 unnamed

601 TO-02 unnamed

602 TO-02 unnamed

603 TO-02 unnamed

604 TO-03 unnamed

605 TO-04 unnamed

606 TO-05 unnamed

607 TO-07 unnamed

608 TO-07 unnamed

609 TO-08 unnamed

610 TO-09 unnamed

611 TO-10 Bureau of Land Mgmt.

612 TO-11 Bureau of Land Mgmt.

613 TO-12 Bureau of Land Mgmt

614 TO-13 Bonnevilie SF \#67

$615 \mathrm{TO}-14$
$616 \mathrm{TO}-15$
$64 \mathrm{rea}$

617 TO-16 Bonneville SF \#K10

618 To-16 Bonnevilie SF \#KIO

620 TO-18 Bureau of Land Mgmt.

621 TO-19 Bonneville SF \#64

622 TO-20 Bonnevilie Ltd. \#24

$\begin{array}{lll}623 & \text { TO-21 } & \text { Kaiser FW } 20 \text { (BLM) } \\ 624 & \text { TO-22 } & \text { Bureau of Land Mgmt. }\end{array}$

625 TO-23 unnamed

626 TO-24 unnamed

627 TO-25 Bureau of Land Mgmt.

$628 \mathrm{TO}-26$ Bureau of Land Mgmt.
$629 \mathrm{TO}-27$ Bureau of Land Mgmt.

630 TO-28 Asarco

$\begin{array}{lll}631 & \text { TO-28 } & \text { ASARCO } \\ 632 & \text { TO-29 } & \text { unnamed }\end{array}$

633 TO-30 unnamed

$634 \mathrm{TO}-31$

unnamed

635 T0-33 Div. Wildife Res.
$\begin{array}{lllll}(C-04-01) 22 a b & 40.4580 & 111.9260 & 4478794 & 421485\end{array}$ (C-04-01) $23 \mathrm{cbb} \quad 40.4560 \quad 111.9270 \quad 4478572 \quad 422398$ (C-04-01) $23 \mathrm{dbb} \quad 40.4558 \quad 111.91894478543 \quad 422084$ (C-04-02) 09abc $40.4897 \quad 112.06974482450409343$ (D-01-01) 19bac $40.7220 \quad 111.8800 \quad 4508058 \quad 425678$ $\begin{array}{lllll}(D-02-01) 04 \mathrm{Cda} & 40.6706 & 111.8436 & 4502322 & 428698\end{array}$ (D-03-01) 01cac 40.5853 111.8044 4492905423461 (D-03-01) 19bba $40.5508 \quad 111.88674489060424921$ (D-03-01)29cbc $40.5272 \quad 111.87084486427426241$ (D-03-01) $29 \mathrm{cbc} \quad 40.5270 \quad 111.86804486403 \quad 426478$ (D-04-01) 06caa $40.4997 \quad 111.88194483384 \quad 425270$ (A-02-05) 04bcd $40.9378 \quad 111.3942 \quad 4531715 \quad 466815$ (D-01-04) 33aaa $40.6970 \quad 111.49324505029458178$ (D-02-04) 02aac $40.6800 \quad 111.45614503124 \quad 461455$ (D-02-05) 17Cda $40.6419 \quad 111.38974498868 \quad 467048$ (B-01-09) 24cdd $40.7980 \quad 112.8100 \quad 4517587 \quad 347302$ $(\mathrm{B}-01-15) 07 \mathrm{cab}$ $(B-01-15) 07 \mathrm{Cab}$ $(\mathrm{B}-01-15) 07 \mathrm{cab}$ $(\mathrm{B}-01-15) 07 \mathrm{Cab}$ 40.8411 $\begin{array}{llll}113.6056 & 4524174280323\end{array}$ $40.8411 \quad 113.6056 \quad 4524174 \quad 280323$ $40.8411 \quad 113.6058 \quad 4524175 \quad 280306$ $\begin{array}{llllll}\mathrm{B}-01-15) & 07 \mathrm{cab} & 40.8411 & 113.6058 & 4524175 & 280306\end{array}$ $\begin{array}{lllll}B-01-15) 07 \mathrm{cab} & 40.8411 & 113.6053 & 4524173 \quad 280348\end{array}$ $\begin{array}{llllll}B-01-15) 07 \mathrm{cab} & 40.8411 & 113.6053 & 4524173 & 280348\end{array}$ (15) $07 \mathrm{cab} 40.8411 \quad 113.60534524173280348$ $\begin{array}{lllll}\mathrm{B}-01-15) 07 \mathrm{cba} & 40.8411 & 113.6069 & 4524177280213\end{array}$ (B-01-15) 07cba $40.8411 \quad 113.6069452417728021$ (B-01-16) 07dda $40.8375 \quad 113.70694524034271769$ B-01-17) Olaaa $40.8639 \quad 113.72614527015270241$

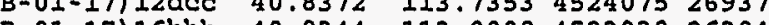
$\begin{array}{lllll}B-01-17) 16 b b b & 40.8344 & 113.8008 & 4523938 & 263840\end{array}$ (B-01-17) 22aad $40.8200 \quad 113.76444522242266859$ (B-01-17) 24bbd $40.8200 \quad 113.74424522189268563$

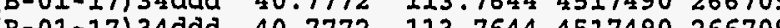
(B-01-17) 34ddd $40.7772 \quad 113.76444517490266709$ (B-01-17) 35cdd $40.7772 \quad 113.75334517461267646$ (B-01-18) 12bab $40.8497 \quad 113.85064525773259695$

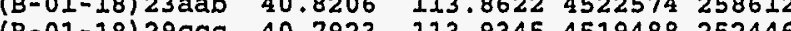
(B-01-18). 40.7923 113.9345 4519488 252446 (B-01-18).31ace $40.7867 \quad 113.94454518961251583$ $(B-01-18) 34 \mathrm{bbb}$ $(\mathrm{B}-02-12) 32 \mathrm{acc}$ $(\mathrm{B}-02-16) 19 \mathrm{ccd}$ (B-02-17) 27aac $(\mathrm{B}-02-17) 33 \mathrm{Cdd}$ $(\mathrm{C}-01-03) 17 \mathrm{bc}$ $(\mathrm{c}-01-03) 17 \mathrm{bc}$ $(\mathrm{C}-01-05) 31 \mathrm{abc}$ $(\mathrm{C}-01-05) 33 \mathrm{dcb}$ (C-01-06) 27 aad $40.7914 \quad 113.8975 \quad 4519430 \quad 255527$ $\begin{array}{lllll}40.8561 & 113.2275 & 4524959 & 312245\end{array}$ $40.8933 \quad 113.7250 \quad 4530276 \quad 270435$ $40.8933 \quad 113.72504530276270435$ $40.8642 \quad 113.79284527225264620$ $40.7280 \quad 132.20104509045398576$ $40.7280 \quad 132.20104509045398576$ 40.684112 .201045094539576 $40.6822 \quad 112.42004504237379999$ 40.682 112.4200450423737999 $40.7064 \quad 112.50644507045372743$ (c-01-07) 09caa $\underset{(\mathrm{m})}{\text { DEPTH }} \quad$ STA FLOW ILEVEL (I/min)

REFERENCE

$\begin{array}{llll}\left.{ }^{\circ} \mathrm{C}\right) & (\mathrm{m}) \quad(\mathrm{L} / \mathrm{min}) & (\mathrm{m}) & \\ 21.0 & & & \end{array}$

79.9

32.0

Hely and others, 1967

Klauk, 1984

Hely and others, 1968

Klauk, 1984

Klauk, 1984

Klauk, 1984

Klauk, 1984

$84.0 \quad 1325.0$

Iorns and oth

Klauk, 1984

WATSTORE

Baker, 1970

WATSTORE

Hood and Waddell, 1968

$66.0 \quad 151.0$

0.4 WATSTORE

0.4 WATSTORE

0.4 WATSTORE

2.3 WATSTORE

0.4 WATSTORE

0.9 WATSTORE

0.9 WATSTORE

1.1 WATSTORE

0.5 WATSTORE

0.3 WATSTORE

0.2 WATSTORE

WATSTORE

STORE

0.1 WATSTORE

WATSTORE

WATSTORE

2.3 WATSTORE

WATSTOR

2.7

51.0

91.0
2.7

2.7
1.7

1.7

1.5
2.7

2.4

153.0
153.0

21.0

23.0

20.5
19.0
22.2

1.0 GATSTÓRE

1.5 WATSTORE

1.5 WATSTORE

0.5 WATSTORE

Marine, 1960

11356.2
11356.0

Marine, 1960

0.6 WATSTORE

1.1 WATSTORE

COle, 1983

11400.0

Hood and Waddell, 1968 
ID MAP NO. SOURCE NAME

637 TO-34 unnamed

639 TO-36 $\quad$ C. Hammond

640 TO- 37 unnamed

641 TO-38 unnamed

642 TO-39 unnamed

643 TO-40 unnamed

644 TO-41 unnamed

645 TO-42 unnamed

646 TO-43 unnamed

647 TO-44 unnamed

648 TO- 45 unnamed

649 TO-46 Bonneville SF \#84

650 TO-47 Bonneville SF \#21

651 TO-48 Bonneville SF \#86

652 TO-49 Bureau of Land Mgmt

654 TO-51 unnamed

655 TO-52 Bureau of Land Mgmt.

656 TO-53 Kaiser Chemical Corp.

657 TO-54 unnamed

658 TO-55 Kaisex Chemical Corp.

659 T0-56 Bonneville SF \#27

660 T0-57 Bonneville Ltd. \#13

661 TO-58 Bureau of Land Mgmt

662 TO- 59

663 TO-60 Bureau of Land Mgmt.

664 TO-61 Bureau of Land Mgmt.

665 To-62 Bonneville SF \#K5

666 TO-62

$667 \mathrm{T0}-63$

$66810-64$

670 TO-66

Bonnevilie SF \#K5

Bonnevilile Ltd. DBW 7

Kaiser DBW 9

cott corp.

672 To-68 R. Boyce

673 T0.69 Casity

675 T0-70 J. Palmer

676 TO-71 unnamed

677 TO-72 N. Lemmon

678 TO-72 N. Lemmon

679 TO-73 M. Mortensen

681 T0-75 Bountiful Livestock

682 T0-75 T. Mathews

$\begin{array}{lll}682 & \mathrm{~T} 0-76 & \mathrm{~T} . \text { Mathews } \\ 683 & \mathrm{~T} 0-77 & \mathrm{~T} . \text { Mathews }\end{array}$

684 T0-78 unnamed

685 T0-79 J.Smith

685 T0.80 Grantsville Wm Spr.

687 T0-80 Grantsville Wm Spr.

688 T0-80 Grantsuille Wm Spr.

689 TO-80 Grantsvilie Wm Spr.
LOCATION

W? (C-01-07) 15bab $40.7330 \quad 112.6233 \quad 4510175 \quad 362863$ (C-01-07) 25acc 40.7010 112.5770 4506551366768 (C-01-08) 06abc $40.7650 \quad 112.78804513775 \quad 349081$ (C-01-14) I8bad $40.7356 \quad 113.4756 \quad 4512144 \quad 290953$ (C-01-14) 18bad $40.7356 \quad 113.4753 \quad 4512143 \quad 290978$ (C-01-14) l8bad $40.7353 \quad 113.47534512110290978$ (C-01-15) 07 add $40.7561 \quad 113.5803 \quad 4514674 \quad 282178$ (C-01-15) 07add $40.7564 \quad 113.58004514707282204$ (C-01-15) 07add $40.7564 \quad 113.58004514707282204$ (C-01-15) 07add $40.7564 \quad 113.57974514706282230$ (C-01-15) 07add $40.7564 \quad 113.57974514706 \quad 282230$ (C-01-15) 07add $40.7564 \quad 113.57974514706282230$ (C-01-17) 01bab $40.7769 \quad 113.7250 \quad 4517353 \quad 270033$ (C-01-17) 05aaa $40.7764 \quad 113.79114517473 \quad 264453$ (C-D1-17) 13bbb $40.7475 \quad 113.73284514109269273$ (c-01-17) 17bba $40.7481 \quad 113.8086 \quad 4514378262$ (C-01-17) 21aba $40.7325 \quad 113.7756 \quad 4512558 \quad 265607$ (c-01-18) 03bbb 40.7761 (C-01-18) 03bbb $40.7761 \quad 113.8836 \quad 4517692 \quad 256644$ $(C-01-18) 11 \mathrm{ccd} 40.7486 \quad 113.863$ (C-01-18) 11ccd $40.7486 \quad 113.86394514585258207$ (C-01-18) 16dac $40.7378 \quad 113.88694513449256226$ (C-01-18) 18ada $40.7439 \quad 113.92314514228253191$ (c-01-19) 02adb $40.7720 \quad 113.9643 \quad 4517466 \quad 249758$ (C-01-19) 02cbd 40.7669 113.9764 4516933 248777 (c-01-19) 03adc $40.7637 \quad 113.98304516621 \quad 248462$ (C-01-19) 10aba $40.7622 \quad 113.98644516440247915$ (c-01-19) loace 40.7553 113.9875 4515677247796 (c-01-19) 10bac 40.7600 113.9914 4516210247484 (c-01-19) lobac 40.7600 113.9914 4516210 247484 (C-01-19) $34 \mathrm{bdc} 40.6252 \quad 113.99284509553247122$ (C-01-29) 35bcd $40.6990 \quad 113.97604509393248555$ (C-02-04)03cbc $40.6700 \quad 112.29284502717390729$ (C-02-04)03cb 40.6700 112.2928 4502717390729 (c-02-04) 32ca $40.5992 \quad 112.32614494900387796$ (c-02-05) 13bca $40.6469 \quad 112.36674500247384442$ (c-02-05) 13bca $40.6469 \quad 312.36674500247384442$ (C-02-05) 33dad $40.5972 \quad 112.40894494787380786$ (c-02-05) 33dcd $40.5964 \quad 112.41224494702380505$ (C-02-05) 34bca $40.6031 \quad 112.40334495434381270$ (c-02-05) 34bca $40.6031 \quad 112.40334495434381270$ (c-02-05) $34 \mathrm{cbc} 40.5970 \quad 112.40604494761381031$ (C-02-05) 35add $40.6014 \quad 112.3703 \quad 4495201 \quad 384059$ (C-02-05) $35 \mathrm{cbd} \quad 40.5986 \quad 112.3842 \quad 4494909382878$ (c-02-05) 35dbb $40.6006 \quad 112.3778 \quad 4495123 \quad 383423$ (c-02-05) $35 \mathrm{dbb} \quad 40.5997 \quad 112.3786 \quad 4495024 \quad 383354$ (C-02-05) 36cba $40.6008 \quad 112.3661 \quad 4495129 \quad 384414$ (c-02-05) 36ded $40.5964 \quad 112.4122 \quad 4494702 \quad 380505$ (C-02-06) 16aad $40.6470 \quad 112.52424500479371058$ (C-02-06) 16aad $40.6470 \quad 112.52424500479371058$ (C-02-06) 16aad $40.6470 \quad 112.52424500479371058$
DEPTH STA FLOW LEVEL

REFERENCE

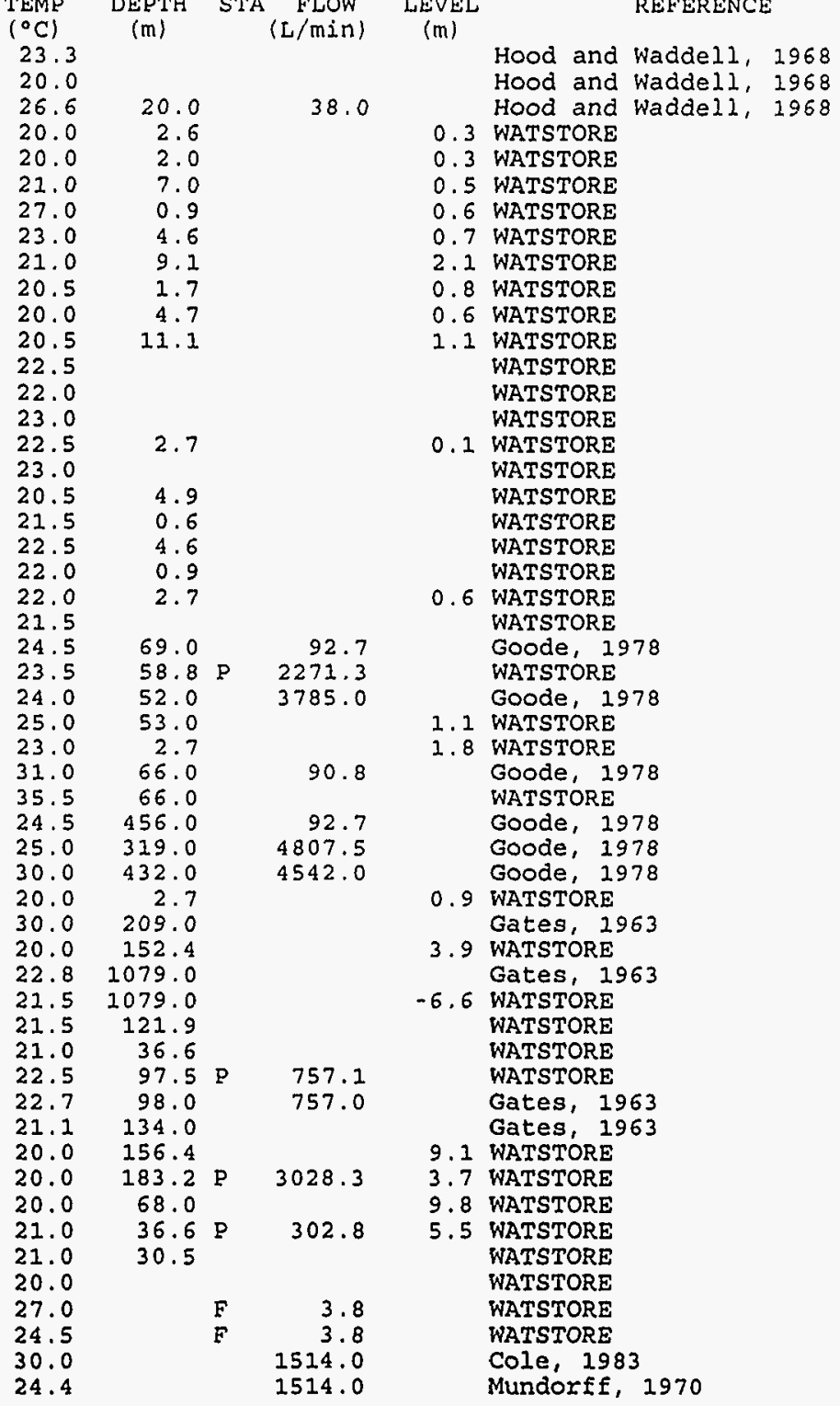


ID MAP NO. SOURCE NAME

690 TO-81 unnamed

691 TO-82 J. Worthington

692 To-82 J. Worthington

694 TO-84 $\mathrm{J}$. Worthington

695 TO-85 unnamed

695 TO-85 unnamed

697 TO-87 So. Horseshoe

$\begin{array}{lll}697 & \text { TO-87 } & \text { So. Ho } \\ 698 & \text { TO-88 } & \text { Redlum }\end{array}$

699 TO-89 Bonneville SF \#K65

700 T0-89 Bonneville SF \#K65

701 TO-90 Bonneville SF \#113

702 TO-91 Bonneville SF \#K66

703 TO-92 Bonnevilile SF \#114

704 TO-93 Bureau of Land Mgmt.

705 TO-94 Kaiser DBW 8

706 To-95 Bonneville Ltd. DBW I $W$

707 TO-96 Bonneville Ltd. DBW $3 \mathrm{~W}$

$\begin{array}{lll}708 & \text { TO }-97 & \text { unnamed } \\ 709 & \text { TO-98 } & \text { City of Tooele } \\ 710 & \text { TO-99 } & \text { H. Clegg }\end{array}$

711 To-100 Deseret Livestock So.

712 To-101 Deseret Livestock so.

714 TO-102 Deseret Livestock Spr.

715 To-103 Blue Lake Spr.

716 TO-103 Blue Lake Spr.

717 TO-104 unnamed

718 TO-105 unnamed

720 T0-106 Morgans Warm Spr.

721 TO-107 Russels Warm Spr.

722 TO-108 R. Davis

723 TO-109 Wilson Health Spr.

725 TO-109 Wilson Health Spr.

726 T0-109 wilson Health spr.

727 UI -01 I. Hullinger

728 UI-02 Below Winter storage

$\begin{array}{lll}728 & \text { UI }-02 & \text { Below Win Warm Spr. } \\ 729 & \text { UI-03 } & \text { Split Mt Warm } \\ 730 & \text { UI-03 } & \text { Split Mt Warm Spr. }\end{array}$

731 UI-04 Pan Am Pet. \#1 Gentry

732 UI-05 Pan Am Pet. ER-10

733 UI-06 Pan Am Pet. ER-1

734 UI -07 T.E. Hall \#5S

736 UI-09 Holiandsworth \& TravisW

$737 \mathrm{UI}-10$ Lacy OiI Field Drain D

738 UI-11 Polumbus Corp. No. 1 W

739 UI-12 Union Irrigation

740 UI-13 BHP Petroleum tnk

742 UI-15 well near Jensen, UT W
TP LOCATION LATITUDE LONGITUDE UTM.N UTM.E

W (c-02-06)16adb $40.6464 \quad 112.52674500414370913$ (C-02-06) $23 \mathrm{cbb} \quad 40.6270 \quad 112.5017 \quad 4498228 \quad 372795$ $(\mathrm{C}-02-06) 23 \mathrm{cbb} \quad 40.6270 \quad 112.52004500360371478$ $\begin{array}{lllll}(\mathrm{c}-02-06) 23 \mathrm{cbb} & 40.6339 & 112.5033 & 4498993 & 372868\end{array}$ $\begin{array}{lllll}(\mathrm{C}-02-06) 23 \mathrm{cbb} & 40.6339 & 112.5033 & 4498993 & 372868\end{array}$ $\begin{array}{llllll}\text { (C-02-08)24CC } & 40.7330 & 112.6233 & 4510175 & 362863\end{array}$ (C-02-08)26bad $40.6142 \quad 112.70854496987355595$ (C-02-08)26dba $40.6133 \quad 112.70924496667 \quad 354912$ (C-02-09) 07cb $40.6560 \quad 112.9073 \quad 4502114 \quad 338525$ $\begin{array}{lllll}(C-02-17) 04 a a c & 40.6869 & 113.7756 & 4507495 & 265446\end{array}$ (c-02-17) 04aac $40.6869 \quad 113.77564507495 \quad 265446$ (C-02-17) 07dcc $40.6611 \quad 113.81694504742261864$ $\begin{array}{llllll}(\mathrm{C}-02-17) 16 \mathrm{caa} & 40.6528 & 113.7808 & 4503723 & 264887\end{array}$ $\begin{array}{llllll}(\mathrm{C}-02-17) 30 \mathrm{bb} & 40.6322 & 113.8283 & 4501564 & 260797\end{array}$ $(\mathrm{C}-02-18) 27 \mathrm{cbb} \quad 40.6244 \quad 113.88394500851256066$ (c-02-19) 03bcd $40.6832 \quad 113.99454507563246800$ (c-02-19) 1420 a $40.6520 \quad 113.96004504129249731$ (C-02-29) 24cba $40.6380 \quad 113.95404502558250186$ (C-03-03)28bca $40.5319 \quad 112.18974487264399236$ (c-03-04)32bbc $40.5193 \quad 112.33004485445387492$ (C-03-05) 01aca $40.5889 \quad 112.35674493796385189$ (c-03-08) 10cce $40.5650 \quad 112.74174491607352442$ (c-03-08) 25cba $40.5555 \quad 112.73904490602352761$ (c-03-08)15cba $40.5555 \quad 112.73904490602 \quad 352761$ $\begin{array}{llllll}(\mathrm{C}-03-08) 21 \mathrm{dab} & 40.5370 & 113.9540 & 4502558 & 250186\end{array}$ (C-04-19) 06dcd $40.5020 \quad 114.03804487701242560$ (C-04-19) 06dcd $40.5020 \quad 114.03804487701242560$ (C-04-19) 07abc $40.4989 \quad 114.04424487375 \quad 242023$ (C-04-19) 20abb $40.4708 \quad 114.0247 \quad 4484198243569$ (C-05-05) 09cba $40.3967 \quad 112.4033 \quad 4472691379406$ (C-05-05) 09cba $40.3967 \quad 112.40334472691379406$ (C-05-05)17aa $40.3900 \quad 112.42404471807379137$ (C-07-05) 32aba $40.1710 \quad 112.42504447499 \quad 378746$ (c-10-14) 33cdc $39.9064 \quad 113.4303 \quad 4419986292251$ (c-10-14) 33cdc $39.9064 \quad 113.4303 \quad 4419986292251$ (C-10-14) 33cdc $39.9064 \quad 113.43034419986292251$ (c-10-14) 33cdc $39.9064 \quad 113.4303 \quad 4419986292251$ (D-03-21) 30dcd $40.5211 \quad 109.60174486325618451$ (D-04-22) 34cdd $40.4211 \quad 109.4333 \quad 4475464 \quad 632914$ (D-04-24) 16cdd $40.4656 \quad 109.22114480745650818$ (D-04-24) 16cdd $40.4656 \quad 109.2211 \quad 4480745650818$ (D-05-22)22ac $\quad 40.3710 \quad 109.4270 \quad 4469913633548$ (D-05-22) 22acd $40.3650 \quad 109.4267 \quad 4469250633729$ (D-05-22)23CCa $40.3650 \quad 109.4180 \quad 4469371634322$ (D-05-22) 23cda $40.3640 \quad 109.4140 \quad 4469155 \quad 634665$ (D-05-22) $23 \mathrm{cdb} \quad 40.3650 \quad 109.4160 \quad 4469263 \quad 634493$ (D-05-22) 23 dcb $40.3650 \quad 109.4110 \quad 4469271634918$ (D-05-22) 23ddd $40.3631 \quad 109.40394469071635525$ (D-05-22) 24ddd $40.3620 \quad 109.3850 \quad 4468978 \quad 637132$ (D-05-22) 25bdc $40.3580 \quad 109.3970 \quad 4468515 \quad 636121$ (D-05-22)26aab $40.3603 \quad 109.40474468759635462$ $\begin{array}{llllll}(D-05-22) 26 \mathrm{da} & 40.3620 & 109.4150 & 4468932 & 634584 \\ (D-05-23) 20 \mathrm{caa} & 40.3672 & 109.3558 & 4469601 & 639601\end{array}$
TEMP
$\left({ }^{\circ} \mathrm{C}\right)$
$(\mathrm{m})$

$\begin{array}{cccc}21.0 & (\mathrm{~m}) & (\mathrm{I} / \mathrm{min}) & (\mathrm{m}) \\ 2.7 & & 1.8 \text { WATSTORE }\end{array}$

20.0

20.0

20.0

20.0

22.2
22.7

22.7

21.1

21.0

21.5

22.0

22.0

43.0

88.0

26.0
21.7

21.7
20.0
22.7

22.7
21.0

21.7
23.9

29.0

29.0

27.0

24.0

21.7

20.0

60.5

55.5

59.0
25.0

21.0

30.0

31.0
46.0

$44.5 \quad 1320.0$

$44.5 \quad 1320.0$

50.0

50.0
56.0

45.0

45.0
20.0

40.0

49.0
20.0
$64.0 \quad 1136.0$

64.0

95.0

7.6

6.0

15.5

2.7

366.0

630.0

219.0
139.6

6814.0

12000.0

871.0
38.0

F 38611.2

3785.4

2839.0

3785.0

2271.0

106.0

$42.1 \mathrm{~F} \quad 380.0$

15.1

F 10220.6

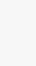

\section{A-15}


ID MAP NO. SOURCE NAME

743 UI-16 Garner \#1 Boesche 744 UI-16 Garner \#1 Boesche 745 UI -17 Roadside Well NR I 746 UT-18 Roadside Well NR2 747 UI-19 Roadside Well NR3 748 UI-20 Sheppard Well (NWR) 749 UI-21 Shell Oil \#I state 750 UI-22 Wosco Test Hole 751 UI -23 unnamed

752 UI-24 U.S. Geol. Survey 753 UI -25 Bureau of Land Mgmt. 754 UI -26 Tennec Bit $\mathrm{Cr} 1$

755 UI-26 Tennec Bit Cr 1

756 UI -27 unnamed

757 UI-28 Bureau of Land Mgmt. 758 UI-28 Bureau of Land Mgmt. 759 UI-28 Bureau of Land Mgmt. 760 UI -28 Bureau of Land Mgmt. 761 UI -29 unnamed

762 UI-30 U.S. Geol. Survey 763 UI-31 Shamrock Corp.

764 UI-32 Bureau of Land Mgmt. 765 UI -32 Bureau of Land Mgmt. $\begin{array}{lll}766 & \text { UI }-32 & \text { Bureau of Land Mgmt } \\ 767 & \text { UI }-33 & \text { U.S. Geol. Survey }\end{array}$ 767 UI -33 U.S. Geol. Survey $\begin{array}{lll}768 & \text { UI }-33 & \text { U.S. Geol. Survey } \\ 769 & \text { UI }-33 & \text { U.S. Geol. Survey }\end{array}$ 770 UI -33 U.S. Geol. Survey 771 UI -34 Bureau of Land Mgmt. 772 UI -34 Bureau of Land Mgmt. 773 UI-34 Bureau of Land Mgmt. 774 UI-35 Shamrock Corp.

776 UI -35 Shamrock Corp.

777 UI -36 unnamed

778 UI -37 U.S. Geol. Survey

779 UI-38 Bureau of Land Mgmt.

780 UI -39 unnamed

781 UI -40 Pleasant valley

782 UT-01 $S$.

783 UT-02 V.V. LDS Church

784 UT-03 W. Ennis

785 UT-04 Board of Canal pres.

786 UT-05 Crater Hot Spr.

787 UT-06 Sugarhouse LDS Church 788 UT -07 unnamed

789 UT-08 F. Eastmond

790 UT-09 Saratoga Hot Spr. -2

791 UT-10 Saratoga hot Spr.-3

792 UT-11 Saratoga Hot Spr.-1

794 UT -12 M. Shiba

795 UT-13 unnamed

LOCATION

LATITUDE LONGITUDE UTM.

UTM.E

(D-06-23) 01bad $40.3320 \quad 109.2790 \quad 4465818 \quad 646198$ (D-06-23) 01bad $40.3320 \quad 109.2790 \quad 4465818 \quad 646198$ $\begin{array}{lllll}(D-08-20) 10 c c b & 40.1367 & 109.6625 & 4443577 & 613945\end{array}$ $\begin{array}{lllll}\mathrm{D}-08-20) 10 \mathrm{ccb} & 40.1347 & 109.6622 & 4443355 & 613974\end{array}$ $\begin{array}{lllll}(D-08-20) 10 \mathrm{CCC} & 40.1319 & 109.6614 & 4443045 & 61404\end{array}$ D-08-20) 21aaa $40.1106 \quad 109.6644 \quad 4440677613827$ D-08-20) 36baa $40.0850 \quad 109.6150 \quad 4437900618082$ $\begin{array}{lllll}(D-09-20) 36 \text { ddc } & 39.9850 & 109.6070 & 4426923 & 618936\end{array}$ $\begin{array}{llllll}(D-09-22) 01 \mathrm{Caa} & 40.0647 & 109.3883 & 4435973 & 637451\end{array}$ $\begin{array}{llllll} & 0-09-23) 22 \mathrm{acc} & 40.0228 & 109.3106 & 4431445 & 644166\end{array}$ $\begin{array}{lllll}(D-10-20) 35 b b c & 39.9092 & 109.6381 & 4418357 & 616410\end{array}$

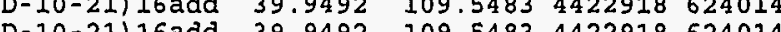

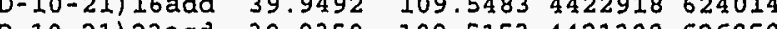
$\begin{array}{lllll}(D-10-21) 23 \text { acd } & 39.9350 & 109.5153 & 4421388 & 626859\end{array}$ (D-10-22) l7aad $39.9542 \quad 109.45564423606 \quad 631924$ $\begin{array}{llll} & \end{array}$ D-10-22) 17aad $39.9542 \quad 109.45564423606631924$ D-10-22) 34bdb $39.9078 \quad 209.4578443496 \quad 634389$ (D-11-21) 1 cad $39.8428 \quad 109.57364411073622041$ (D-11-23) 13dcd $39.8543 \quad 109.28854412750646711$ (D-11-24) $06 \mathrm{dbc} 39.8883 \quad 109.27254416578647707$ (D-11-24)06dbc $39.8883 \quad 109.27254416578647707$ (D-11-24) 06abc $39.8883 \quad 109.27254416578647707$ (D-11-24) 07acd $39.8772 \quad 109.26894415352648038$ (D-11-24) 07 acd $39.8772 \quad 109.26894415352 \quad 648038$ $\begin{array}{lllll}D-11-24) 07 a c d & 39.8772 & 109.2689 & 4415352 & 648038\end{array}$ $\begin{array}{llllll}D-11-24) 07 a c d & 39.8772 & 109.2689 & 4415352 & 648038\end{array}$ D-11-24)07Cac $39.8744 \quad 109.27614415029647429$ (D-11-24)07cac $39.8744 \quad 109.27614415029647429$ D-11-24)07Cac $39.8744 \quad 109.2761 \quad 4415029647429$ (D-11-24) 08Caa $39.8758 \quad 109.2544 \quad 4415221649282$ (D-11-24) 08caa $39.8758 \quad 109.2544 \quad 4415221649282$ (D-11-24)08caa $39.8758 \quad 109.2544 \quad 4415221 \quad 649282$ (D-12-22) 010bb $39.8097 \quad 109.41084407635636036$ (D-13-19) 08baa $39.7070 \quad 109.80704395709602272$ (C-02-01) 15dd* $40.3025 \quad 109.97674461624586965$ (C-04-01) 23 |) * $40.1167 \quad 109.96694441011588038$ (C-05-01) 23bda $40.3730 \quad 111.91604469350422235$ (c-05-01) 24dcd $40.3640 \quad 111.8920 \quad 4468330 \quad 424262$ (C-05-01) 24ddc $40.3640 \quad 111.8900 \quad 4468328 \quad 424432$ (c-05-01) 25abc $40.3600 \quad 113.90604467898423069$ (c-05-01) $25 \mathrm{bbc} 40.3570 \quad 111.8950 \quad 4467112423995$ (C-05-01) $25 \mathrm{cbb} \quad 40.3550 \quad 111.9050 \quad 4467342 \quad 423148$ (C-05-01) 25cca $40.3508 \quad 111.90114466873423475$ (C-05-01)25ccC $40.3590 \quad 111.9050 \quad 4467786 \quad 423153$ (c-05-01) $25 \mathrm{ccc}$ $(C-05-01) 25 \mathrm{ccc}$ $40.3494 \quad 111.9047 \quad 4466720 \quad 423168$ $40.3611 \quad 111.9036 \quad 4468018423274$ $40.3489 \quad 111.9053 \quad 4466665423116$ (C-05-01)25CCC $40.3489 \quad 111.9053 \quad 4466665423116$ $\begin{array}{llllll}(\mathrm{C}-05-01) 26 \mathrm{bdb} & 40.3590 & 111.9180 & 4467798 & 422049 \\ (\mathrm{C}-05-01) 36 \mathrm{ddd} & 40.3322 & 111.8889 & 4464798 & 424490\end{array}$

TEMP

$\begin{array}{cccc}\text { TEMP } & \text { DEPTH } & \text { STA FLOW } & \text { LEVEL } \\ \left({ }^{\circ} \mathrm{C}\right) & (\mathrm{m}) & (\mathrm{L} / \mathrm{min}) & (\mathrm{m})\end{array}$

$\begin{array}{lll}46.0 & 808.0 \quad 757.0\end{array}$

22.0

20.5

20.0

20.0

$57.5 \quad 1711.0$

$23.5 \quad 986.0$

28.0

$\begin{array}{lllll}26.0 & 554.7 & \mathrm{P} & 2649.8\end{array}$

$29.0-1728.2$ F 220.7

$\begin{array}{ll}27.0 & 1706.9 \\ 33.5 & 1706.9\end{array}$

28.5

$22.0 \quad 2135.0 \quad 11.0$

$\begin{array}{llll}23.5 & 2133.6 & \mathrm{~F} & 37.8 \\ 21.5 & 2133.6 & \mathrm{~F} & 37.8\end{array}$

$21.5 \quad 2135.0 \quad 12.0$

34.0

$22.0 \quad 1478.3$

$26.0 \quad 1785.0$

$28.0 \quad 1813.6$

$28.5 \quad 1814.0$

$25.0 \quad 807.7$

$25.0 \quad 807.7$

$26.0 \quad 807.7$

$26.5 \quad 1780.1$

$26.5 \quad 1780.1$

26.51780 .0

$26.5 \quad 2002.0$

$26.0 \quad 2002.0$

$26.5 \quad 2002.6$

$22.0 \quad 426.7$

$24.0 \quad 170.7 \mathrm{~F}$

24.0
21.5

21.1

21.2

23.9

43.3
35.0

44.5

47.0
43.0

42.0

41.0

44.0

30.0
43.0
32.0

60.0

45.0

32.0

152.0 (m)

38.0

151.0
189.0

$-42.7$

662.5

136.0

68.0

605.7
REFERENCE

Hood and others, 1976 WATSTORE

WATSTORE

WATSTORE

Hood and others, 1976

Hood and others, 1976

WATSTORE

WATSTORE

WATSTORE

WATSTORE

WATSTORE

Conroy and Fields, 1977 WATSTORE

NATSTORE

Conroy and Fields, 1977 WATSTORE

Conroy and Fields, 1977 WATSTORE

Conroy and Fields, 1977

-42.7 WATSTORE

-42.7 WATSTORE

168.9 WATSTORE

Hood and others, 1976

WATSTORE

WATSTORE

Subitsky, 1962

subitsky, 1962

Subitsky, 1962

WATSTORE

Subitsky, 1962

Klauk and Davis, 1984 Klauk and Davis, 1984 Cole, 1983

Subitsky, 1962 
ID MAP NO.

SOURCE NAME

796 UT-14 Fault zone Spr. 797 UT-15 unnamed

798 UT-16 Coop Security

799 UT-17 unnamed

800 UT-18 unnamed

801 UT-19 unnamed

802 UT-20 unnamed

803 UT-21 unnamed

805 UT -23 unnamed

805 UT -23 unnamed

806 UT 24 unnamed

807 UT-25 unnamed

808 UT-26 unnamed

809 UT 27 unnamed

810 UT 28 unnamed

812 UT -30 Coop. Security Corp.

813 UT-31 Coop. Security Corp.

814 UT-31 Coop. Security Corp.

835 UT-32 unnamed

816 UT-33 Lazy S Cattle Co.

817 UT-34 Lazy S Cattle Co.

818 UT -35 LDS Church

819 UT-36 unnamed

821 UT-38 Burgin Mine

822 UT-39 Elberta E. Crop Unit

823 UT -40 C. Jones

824 UT -41 unnamed

$\begin{array}{lll}825 & \text { UT }-42 & \text { unnamed } \\ 826 & \text { UT }-43 & \text { H. Williamson }\end{array}$

827 UT -44 W shore of Utah Lake 828 UT -45 W shore of Utah Lake 829 UT -46 unnamed

830 UT -47 Bird Is. Warm Spr.

831 UT -47 Bird Is. Warm Spr.

832 UT -48 Wood Spr.

833 UT-49 City of Springville

834 UT-50 unnamed

835 UT -51 unnamed pnt Wm Spr.

837 UT-52 Lincoln pnt Wm Spr.

838 UT -53 unnamed

839 UT -54 So. Shore Farms

840 UT-55 unnamed

841 UT-56 unnamed

842 UT -57 O. Bartholomew

843 UT-58 unnamed

844 UT-59 unnamed

845 UT -60 K. Young

846 UT -61 R.T. Herbert

847 UT-62 Diamond Fk Wm Spr.

848 UT-63 Castilla Hot Spr.
LOCATION

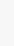

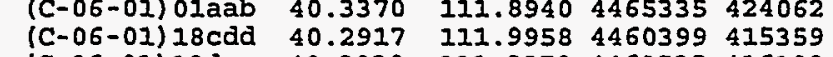
(C-06-01) 18dca $40.2930 \quad 111.98704460535416108$ (C-06-01) 19acc $40.2839 \quad 111.9944 \quad 4459532415468$ (D-08-01) 10bcb $40.1381 \quad 111.82314443200429880$ (C-08-01) $20 \mathrm{cdb} \quad 40.1000 \quad 111.9694 \quad 4439096417370$ (C-08-01) $20 \mathrm{cdb} \quad 40.1006 \quad 111.97004439164417320$ (C-08-01) $20 \mathrm{cdb} \quad 40.1006 \quad 111.97004439164417320$ (C-08-01)29acc $40.0900 \quad 111.96604437983417648$ (C-08-01) 29dda $40.0869 \quad 111.95784437632418343$ (C-08-02) 18ccc $40.1281 \quad 111.76754442047434607$ (C-08-02)29aaa $40.1581 \quad 111.73084445351437761$ (C-08-02) 31cdb $40.0725 \quad 111.76794435876434520$ (C-08-02) 32dda $40.0728 \quad 111.7322 \quad 4435884 \quad 437564$ (C-08-03)03dca 40.1481 111.5872 4444150 449984 (C-09-01) 04CCC $40.0540 \quad 111.95804433980418287$ (C-09-01) 04ddc 40.0525 111.9475 4433804419181 (c-10-01) $04 \mathrm{cbb} \quad 39.9736 \quad 111.9550 \quad 4425054 \quad 418447$ (c-10-01) $04 \mathrm{cbb} \quad 39.9736 \quad 111.9550 \quad 4425054 \quad 418447$ (C-10-01) $28 \mathrm{adb} \quad 39.9186 \quad 111.9392 \quad 4418935419732$ (c-10-01) 29cdd $39.9083 \quad 111.9644 \quad 4417815 \quad 417566$ (c-10-01)29ddd $39.9092 \quad 111.95564417907418320$ (c-10-01) 31cdd $39.8944 \quad 111.98334416290415934$ (c-10-01) 32ccc $39.8933 \quad 111.97074416156417010$ (C-10-01) 33aba 39.9690 111.9398 4424529419740 (C-10-02) 15ddd (C-11-01) 06 bdd (D-04-01) 33 dad (D-06-01) $30 \mathrm{baa}$ (D-06-02) $28 \mathrm{bad}$ (D-07-01) 05ccb (D-07-01) $08 \mathrm{bbc}$ (D-07-01) 26cac (D-07-01) $26 \mathrm{cbd}$ (D-07-01) $26 \mathrm{cbd}$ (D-07-03) $32 \mathrm{~d}$ (D-07-03) $34 \mathrm{cdb}$ (D-08-01) 02 ccb (D-08-01) 02 CCA (D-08-01) 03dda (D-08-01) 03 dda (D-08-01) 09adc (D-08-01) $10 \mathrm{bcb}$ (D-08-02) $25 \mathrm{bca}$ (D-08-02) $28 \mathrm{cbd}$ $(\mathrm{D}-08-02) 28 \mathrm{CCC}$ (D-08-02) 31cda $(D-08-02) 31 \mathrm{cdb}$ $(D-08-02) 32$ aad $(\mathrm{D}-08-02) 33 \mathrm{bbb}$ $\begin{array}{ll}(\mathrm{D}-08-02) 33 \mathrm{bbb} & 40.0860 \\ (\mathrm{D}-08-05) 14 \mathrm{~d} & 40.1170 \\ (\mathrm{D}-09-04) 18 \mathrm{baa} & 40.0383\end{array}$ 111.98334415557415926 $40.4236 \quad 111.83114474895429496$ $40.3587 \quad 111.70594467599 \quad 440059$ $40.2744 \quad 111.8883 \quad 4458382 \quad 424477$ $40.2725 \quad 111.7236 \quad 4458043 \quad 438478$ $40.2350 \quad 111.8640 \quad 4453879 \quad 426329$ $40.2290 \quad 111.8630 \quad 4453212 \quad 426408$ $40.1767 \quad 111.8008 \quad 4447467 \quad 431818$ $40.1764 \quad 111.8017 \quad 4447434 \quad 431741$ $40.1764 \quad 111.80174447434 \quad 431741$ $40.1630 \quad 111.6210 \quad 4445823 \quad 447116$ $40.1614 \quad 111.5908 \quad 4445628 \quad 449687$ $40.1461 \quad 111.8058 \quad 4444074 \quad 431362$ $40.1453 \quad 111.80314443917431590$ $40.1453 \quad 111.80644443986431310$ $40.1367 \quad 111.8286 \quad 4443049 \quad 429410$ $\begin{array}{lllll}40.1383 & 111.8228 & 4443222 & 429906\end{array}$ $40.0956 \quad 111.66894438372 \quad 442981$ $40.0894 \quad 111.7278 \quad 4437723 \quad 437954$ 40.0850 $40.0731 \quad 111.75924435937435262$ $40.0731 \quad 111.7611 \quad 4435938 \quad 435100$ $40.0840 \quad 111.7330 \quad 4437128 \quad 437506$ $\begin{array}{lllll}40.0860 & 111.7300 & 4437348 & 437764 \\ 40.1170 & 111.3370 & 4440587 & 471282\end{array}$ 111.53334432934454502

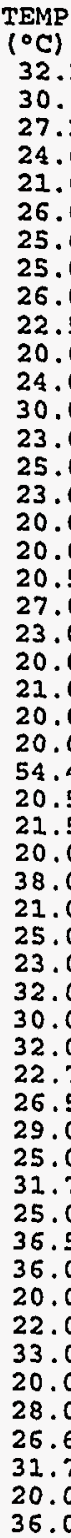

32. (m)

sTe

(I)/min

IEVEL

REFERENCE

$$
80.0
$$

45.0 45.0

210.3

265.2 P

7949.4
7949.4

256.6 P 3596.1

213.4 P 3369.0

$183.8 \mathrm{P} 23025.1$

10200.0

$232.3 \mathrm{P} \quad 10977.7$

P 2097.1

$33.5 \mathrm{~F}$

83.

F $\quad 1253.0$
F $\quad 1298.4$

6208.0

135.6 P 15520.2

21.9

73.2

507.3

84.0

757.0

36.0

67.0

5.7

1700.0
Subitsky, 1962

Feltis, 1967

Klauk and Davis, 1984

WATSTORE

CATSTOR日

WATSTORE

Parry and Cleary, 1978

lauk and Davis, 1984

Klauk and Davis, 1984

Klauk and Davis, 1984

Klauk and Davis, 1984

lauk and Davis, 1984

27.4 WATSTORE

43.9 WATSTORE

Klauk and Davis, 1984

43.9 WATSTORE

37.2 WATSTORE

WATSTORE

Cordova, 1969

Cordova, 1969

74.7 WATSTORE

Fairbanks, 1982

Klauk and Davis, 1984

1.9 WATSTORE

Mundorff, 1970

WATSTORE

Cordova, 1969

WATSTORE

Cordova, 1969

WATSTORE

WATSTORE

Cordova, 1969

10.1 WATSTORE

WATSTORE

5.8 WATSTOR:

Klauk and Davis, 1984

WATSTORE

Cordova, 1969

WATSTORE

WATSTORE

Cordova, 1969

Cordova, 1969

Klauk and Davis, 1984 
ID MAP NO. SOURCE NAME

849 UT-63 Castilla Hot Spr. 850 UT-63 Castilla Hot Spr. 851 UT-63 Castilla Hot Spr. 852 UT-64 Thistle Hot Spr. 853 UT-65 Goshen warm Spr. 854 UT-66 GV Warm Spr. 855 UT -67 unnamed 856 UT -68 s. Elkins 857 UT -69 S. Lunce ford 858 UT-70 Third Water Hot Spr. 859 WA-01 W. Pickering 860 WA-02 Irvine Spr. 861 WA-03 unnamed 862 WA-04 unnamed 863 WA-05 Anderson Ranch 864 WA-06 Veyo Hot Spr. 865 WA-06 Veyo Hot Spr. 866 WA-07 Dixie/Pah Tempe 867 WA-07 Dixie/Pah Tempe 868 WA-07 Dixie/Pah Tempe 869 WA-07 Dixie/Pah Tempe 870 WA-08 Virgin River Spr. 871 WA-09 SnOW Sp. 872 WA-10 City of $S t$. George 873 WA-11 W. Cooper 874 WA-12 Berry Spx 875 WA -13 unnamed 876 WA-14 877 WA -15 878 WA -16 879 WA- 17 880 WA -17 882 WA -19 883 WA -19 884 WA- 20 $885 \mathrm{WA}-21$ 887 WA -23 (88) WA -23 889 WA -23 890 WA- 24 891 WA -25 892 WA-26 893 WA-27 $894 \mathrm{WE}-01$ 895 WE- 01 896 WE-02 898 WE- 04 899 WE- 05 $900 \mathrm{WE}-06$ 901 WE-07
Stratton Turf Farm stratton Turf Farm St. George Cr.

Hot Pot Green Spr.

they

P. Foremaster

W. Hafen

unnamed

nnamed

Gregorson

E. Jones

recor

Patio Spr

Washington Terrace Washington Terrace BWCD Riverdale

E. Penman

A. Vaughn
LOCATION

LATITUDE LONGITUDE UTM.N

UTM. E

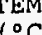

DEPTH

(L/min)

LEVEL

REFERENCE

$S \quad(D-09-04) 18$ baa $\quad 40.0383 \quad 111.5333 \quad 4431934 \quad 454502$ (D-09-04) 18baa $40.0383 \quad 111.5333 \quad 4431934 \quad 454502$ D-09-04) 18baa $40.0383 \quad 111.5333 \quad 4431934 \quad 454502$ $\begin{array}{lllll}(D-09-04) 28 b c b & 40.0300 & 111.5117 & 4431002 & 456339\end{array}$ (D-10-01) 08cab $39.9583 \quad 111.85504423269426971$ (D-10-01) 08cac $39.9570 \quad 111.8590 \quad 4423128 \quad 426628$ (D-10-01) $19 \mathrm{bad} 39.9353 \quad 111.8714 \quad 4420730425545$ (D-10-01) 19bde $39.9314 \quad 111.87394420299425327$ (D-10-01)30bac $39.9203 \quad 111.87424419067425289$ (D-08-05) 25dcd 40.0829 111.3177 4436800472914 (C-37-17) 12bac $37.5822 \quad 113.70974162709260723$ $(C-39-16) 14 \mathrm{dba} \quad 37.3920 \quad 113.61104141355268855$ (c-40-10) $34 \mathrm{ab} \quad 37.2928 \quad 112.9458 \quad 4128925327523$ (c-40-10) $34 \mathrm{ca} \quad 37.2872 \quad 112.94694128306327413$ (c-40-13) 27bab $37.2850 \quad 113.30404128774295747$ (c-40-16) 06abc 37.3183 113.6900 4135219 261945 (c-40-16)06dbc $37.3183 \quad 113.69004135219261945$ (c-41-13) 25cac $37.1900 \quad 113.27174118163298361$ (c-41-13)25cac $37.1900 \quad 113.27274118163298361$ (c-41-13) 25cac 37.1900 113.27174118163298361 (c-41-13) 25cac 37.1900113 .27174118163298361 (C-41-13) 25da $37.1917 \quad 113.27504118355298069$ (c-41-16) 34bda 37.1780 113.6350 4117667266068 $(C-41-17) 17 \mathrm{cba} 37.2181 \quad 113.78444122496252932$ (C-42-14)01bcb 37.1650 2133.38404125634288318 $(c-42-14) 01 \mathrm{beb} 37.1650 \quad 113.38404115634288318$ (C-42 14) 2 dab 37.16102133 .39074215204287774 (C-42-14)15aba $37.1408 \quad 2133.40804113000286050$ (C-42-14) 25bbc $37.1346 \quad 113.40244112300286600$ (C-42-15)06dca 37.1350 133.4024 4112300286600 (C-42-15) 06ded $37.1550 \quad 113.57224114962271575$ (C-42-15) $1100 \mathrm{cc} 37.1383 \quad 113.51174112937276694$ (C-42-25) 15bba $37.1383 \quad 113.52774113076275631$ (C-42-15)15bba $37.1383 \quad 113.52774113076275631$ $(C-42-15) 30 d a d \quad 37.0980 \quad 133.57204108636271421$ $(C-42-15) 33 \mathrm{cbc} 37.0874 \quad 133.54774107400273550$ (C-42-17) $012 a c \quad 37.1633 \quad 113.70174116200 \quad 260100$ (C-43-14) 31bbb $37.0100 \quad 113.47444098641279842$ $(C-43-14) 31 \mathrm{bbb} \quad 37.0100 \quad 113.4744 \quad 4098641279842$ $(\mathrm{C}-43-14) 31 \mathrm{bbb} \quad 37.0100 \quad 113.4744 \quad 4098641279842$ (C-43-15) 10cca $37.0549 \quad 113.52924103750275100$ (C-43-15) 12ccc $37.0525 \quad 113.49374103400278250$ (C-43-16)22dba $37.0290 \quad 113.6250 \quad 4101109266498$ (C-41-15)32aca $37.1794 \quad 113.5558 \quad 4117634 \quad 273107$ (A-07-01)22caa $41.3269 \quad 111.8264 \quad 4575164430841$ (A-07-01)22caa $41.3269 \quad 111.8264 \quad 4575164 \quad 430841$ (B-05-01)17cbc $41.1660 \quad 111.9850 \quad 4557440 \quad 417365$ $W \quad(B-05-01) 17 d d d \quad 41.1672 \quad 111.9681 \quad 4557558 \quad 418785$ W (B-05-01)18abb $41.1750 \quad 111.99604558339416453$ $\begin{array}{llllll}(B-05-02) 07 d a b & 41.1820 & 112.2067 & 4559342 & 406985 \\ & (B-05-02) 14 b d c & 41.1694 & 112.0375 & 4557869 & 412965\end{array}$ $\begin{array}{llllll}(B-05-02) 14 b d c & 41.1694 & 112.0375 & 4557869 & 412965 \\ (B-05-03) 12 d d d & 41.1781 & 112.1222 & 4558923 & 405872\end{array}$ (m)

Klauk and Davis, 2984 Cole, 1983

Klauk and Davis, 1984 Klauk and Davis, 1984 Parry and Cleary, 1978

138.7

82.9

5299.6

$88.4 \quad 178$

178.0

91.0

79.0

341.0

390.0
18169.0

17034.0

18000.0

190.8

98.0

125.0

274.3 P 2779.1

14.0
182.9

38.0

606.0
$F \quad 1287.0$

$217.0 \quad 7192.0$

$\begin{array}{ll}261.2 \mathrm{P} & 4996.7 \\ 23.0 & 9463.0\end{array}$

306.0

9463.0

$304.8 \mathrm{P} \quad 5867.4$

5867.4
113.6 WATSTORE

38.1 WATSTORE
79.2 WATSTORE

this study

WATSTORE

Cordova and others, 1972 WATSTORE

WATSTORE

Cordova and others, 1972 undorff, 1970

Budding and Sommer, 1986 Budding and Sommer, 1986 this study

Mundorff, 1970

Cole, 1983

wanberg and others, 1977 23.2 WATSTORE

Budding and Sommer, 1986 Cordova and others, 1972 Cordova and others, 1972 Corstore

and Sommer, 1986 Budding and Sommer, 2986

buding and Sommer, 1986 Budding and sommer, 1986 Budding and Sommer, 1986 Cordova and others, 1972 Budding and Sommer, 1986 Budding and Sommer, 1986 WATSTORE

WATSTORE

WATSTORE

Budding and Sommer, 1986 Budding and Sommer, 1986 Cordova and others, 1972

145.7 Cordova, 1978

DOYUTIRA,

144.2 WATSTORE

Oolke and waddell, 1972

73.2 WATSTORE
-6.1 WATSTORE 
ID MAP NO. SOURCE NAME

902 WE-08 R. Parkex

903 WE-09 H. Richards

904 WE-10 T. Rhead

905 WE-10 T. Rhead

$907 \mathrm{WE}-11$ Ogden Hot Spr.

908 WE-11 Ogden Hot Spr.

909 WE-11 Ogden Hot Spr.

$911 \mathrm{WE}-12$ Utah Byproducts

912 WE-13 Bona Vista WTRD

913 WE-14 Central Weber STP

914 WE-15 G. Stratford

915 WE-16 2 . Defries

916 WE-17 D. Prevedel

917 WE-18 $E$. Wayment

918 WE-19 $R$. Jacob

920 WE-21 Marquardt ACFT

921 WE-22 Utah Hot Spr.

922 WE-22 Utah Hot Spr.

923 WE-22 Utah Hot Spr.

924 WE-23 R. Penton

$925 \mathrm{WE}-24$ E. Cragun

927 WE-26 GSLM \& C No. 14

928 WE-27 GSLM \& C No. 14

929 WE-27 GSLM \& C NO. 15

930 WE-27 GSLM \& C NO. 15

931 WE-28 GSLM \& C NO. 11

932 WE-29 GSLM \& C No. 4

933 WE-30 GSLM \& C NO. 5

934 WE-31 GSIM \& C No. 3

935 WE-32 GSLM \& C No. 12

936 WE-33 GSLM \& C No. 6

938 WE-35 GSLM \& C No. 8

939 WE-36 GSLM \& C No. 10

940 WE-37 GSLM \& C NO. 9

941 WE-38 GSLM \& C NO. 13

942 WE-39 G. East \#1

$943 \mathrm{WE}-40$ C. Hawkes

944 WE- 41 H. Byingto

946 WS-02 ME. Spa Hot Pot

947 WS-02 Mt. Spa Hot Pot

948 WS-03 Warm Ditch Spr.

949 WS-04 Coleman Hot Spr.

950 WS-04 Coleman Hot Spr.

951 WS-04 Coleman Hot Spr.

952 WS-05 unnamed

953 WS-06 Johnson Well

954 WS-07 GW No. 1
LOCATION

LATITUDE LONGITUDE UTM.N

UTM.E $\begin{array}{llllll}\text { (B-05-03) 15aaa } 41.1750 & 112.1600 & 4558620 & 402697\end{array}$ $\begin{array}{lllll}(B-05-04) 21 \mathrm{cbb} & 41.1540 & 112.3140 & 4556473 & 389744\end{array}$ (B-05-03) 15dda B- $05-03)$ Isda $(\mathrm{B}-06-01) 23 \mathrm{ccd}$ $(\mathrm{B}-06-01) 23 \mathrm{CCd}$ $(\mathrm{B}-06-01) 23 \mathrm{CCC}$ $(B-06-01) 290 b b$ B-06-02) 01acd (B-06-02) $11 \mathrm{bcb}$ $(B-06-02) 25000$ $(B-06-02) 27 \mathrm{dcd}$ $(B-06-03) 04 d a b$ $(B-06-03) 05 \mathrm{CCC}$ $(B-06-03) 10 \mathrm{acb}$ (B-06-03) 19aab (B-07-02) 24ddC (B-07-02) 14 ddC (B-07-02) 14 ddc (B-07-02) 16ded (B-07-02) 25ddd (B-07-02) 34bbb (B-07-03) 31aac (B-07-03) 31aac (B-07-03) 31aac (B-07-03) 3laac (B-07-03) 31adc (B-07-03) 31daa (B-07-03) 31daa (B-07-03) 31daa (B-07-03) 31daa (B-07-03) 31dab (B-07-03) 31dab (B-07-03) 31dac (B-07-03) 31dad (B-07-03) 31dda (B-07-03) $32 \mathrm{cbb}$ (B-07-03) 33cdd (B-05-02) 05acb (B-05-03) 11dad (D-03-04) 26cCa (D-03-04) 26cca (D-03-04) 26cca (D-03-04) $27 \mathrm{aba}$ (D-03-04) 27baa (D-03-04) 27baa (D-03-04) 27baa $(\mathrm{D}-03-04) 27 \mathrm{bad}$ $(D-03-04)$
$(D-03-04) 27 b d d$ 41.2357

112.16174557479402539 $\begin{array}{lll}112.1617 & 4557479 & 402539 \\ 112.1617 & 4557479 & 402539\end{array}$ 111.9237456504442256 111.9237456504442256 111.9237456504442256 (1) 456504442256 $\begin{array}{lllll}2250 & 111.9858 & 4563987 & 417691\end{array}$ $\begin{array}{llll}412.0117 & 4570743 & 415280\end{array}$ 112.02404563473414164 112.05334563608412154 112.05334563608412154 $41.2856 \quad 112.18254570924400977$ $41.2803 \quad 112.21754570341398163$ 112.216804569509402172 $41.2497 \quad 112.2140 \quad 4565903 \quad 398031$ $41.3387 \quad 112.0310 \quad 4576801 \quad 413819$ $41.3387 \quad 112.0310 \quad 4576801 \quad 413819$ $41.3387 \quad 112.03104575801413819$ $41.3364 \quad 112.07064576442410417$ $41.3083 \quad 112.00814573260415611$ $41.3058 \quad 112.0628 \quad 4573037 \quad 411028$ $\begin{array}{lllll}41.3050 & 112.2230 & 4573347 & 397619\end{array}$ $\begin{array}{lllll}41.3028 & 112.2217 & 4572879 & 397721\end{array}$ $\begin{array}{lllll}41.3028 & 112.2217 & 4572879 & 397721\end{array}$ $41.3000 \quad 112.22004572459405813$ $41.3000 \quad 112.2200 \quad 4572459 \quad 405813$ $41.3000 \quad 112.2200 \quad 4572459405813$ $\begin{array}{lllll}41.3012 & 112.2197 \quad 4572459 & 405813\end{array}$ $41.3030 \quad 112.22174572905 \quad 397445$ $41.2990 \quad 112.2217 \quad 4572344 \quad 406062$ $41.2983 \quad 112.2217 \quad 4572122 \quad 406060$ $41.3000 \quad 112.2217 \quad 4572344 \quad 406062$ $41.2982 \quad 112.22174572122406060$ 112.21674572571405730 $41.2940 \quad 112.18934572201400199$ $41.2008 \quad 112.09134561435408270$ $41.1808 \quad 112.1420 \quad 4560799405913$ $40.5220 \quad 111.4710 \quad 4485592 \quad 460102$ $40.5255 \quad 111.46804485592460102$ $40.5255 \quad 111.4680 \quad 4485592 \quad 460102$ $40.5353 \quad 111.4828 \quad 4487074 \quad 459111$ $0.5353 \quad 111.48284487074459111$ $40.5353 \quad 111.4828 \quad 4487074 \quad 459111$ $40.5320 \quad 111.4810 \quad 4486707 \quad 459261$ $\begin{array}{llll}40.5308 & 111.4844 & 4486579 & 458975 \\ 40.5304 & 111.4816 & 4486533 & 459210\end{array}$ $\begin{array}{lllll}41.3028 & 112.2217 & 4572879 & 397721\end{array}$
DEPTH STA FLOW LEVEL

REFERENCE

24.0

20.0

22.2

23.

57.0

56.0
56.0

21.5

(20.5

20.0

25.0

22.0

57.0

58.0

(m)

Bolke and waddell, 197 Bolke and Waddell, 1972 Feth and others, 1966 198.0

7.6 Feth and

197.8

9.8

Murphy and Gwynn, 1979

20.0 Mariner and others, 2983 Cole, 1983

$257.0 \quad 1336.0 \quad$ Bolke and Waddell, 1972 $304.8 \mathrm{~F} \quad 1514.2 \quad-8.5$ WATSTORE

$\begin{array}{lll}289.3 \mathrm{~F} & 83.3 & -11.2 \text { WATSTORE } \\ 171.0 & & \text { Smith, } 1961\end{array}$

191.0

208.0

70.0

14.8

Bolke and Waddell, 1972

-5.2 WATSTORE

Bolke and Waddell, 1972

Bolke and Waddell, 1972

53.0

121.0

$359.7 \mathrm{p} \quad 159.0$

$155.4 \mathrm{~F}$

$157.6 \mathrm{P}$

246.0

280.0

$280.0 \mathrm{P}$

217.0

126.0

126.0

219.0

180.0

189.0

215.0

219.0

122.0

160.0

851.7
75.7

212.0

681.4

283.9

201.0

114.0

151.0

261.0

110.0

273.0

246.0

68.0

113.6
15.1

189.0

F 340.7

F $\quad 340.7$

568.0
Bolke and Waddell, 1972

Mariner and others, 1983 Murphy and

-9.8 WATSTORE

-5.5 WATSTORE

Murphy and Gwynn, 1979

15.8 WATSTORE

Murphy and

Bolke and Waddel I, 1972

Bolke and waddell, 1972

Bolke and Waddeli, 1972

Bolke and Waddel1, 1972

Bolke and Waddell, 1972 Bolke and Waddell, 1972 Bolke and waddell, 1972 Bolke and Waddell, 1972 Bolke and Waddell, 1972 Smith, 1961

Bolke and Waddell, 1972 Bolke and Waddell, 1972

Kaker, 1970

this study

WATSTORE

Kohler, 1979

WATSTORE

Baker, 1970

Kohler, 1979
Kohler, 1979
Bolke and waddell, 1972

Kohler, 1979 
ID MAP NO. SOURCE NAME

955 WS-08 unnamed

956 WS-09 Whitaker Hot Spr.

957 WS-10 GW No. 3

.

959 WY-02 unnamed

960 WY-03 Garkane Power

961 WY-04 Fed. Aviation Admin.

962 WY-05 Bureau of Land Mgmt.

963 WY-06 Cow Wash Spr.

964 WY-06 Cow Wash Spr.
TP

LOCATION

LATITUDE LONGITUDE UTM.N

UTM.E

TEMP

31.0

(D-03-04) $27 \mathrm{cbd}$

$40.5250 \quad 111.4867 \quad 4485711458663$

$40.5174 \quad 111.4755 \quad 4485085 \quad 459719$

$\begin{array}{lllll}\text { D-03-04) 35bba } 40.5214 & 111.4669 & 4485526 & 460451\end{array}$

(D-27-08) lidac $38.4733 \quad 111.01224258124 \quad 498936$

(D-28-03) 26cda $38.3425 \quad 111.55174243755451787$

(D-28-08) 29dcb $38.3410 \quad 111.0700 \quad 4243446494057$

(D-28-11) 16dad $38.3722 \quad 110.7128 \quad 4246945 \quad 525088$

(D-29-10) 22 ccb $38.2675 \quad 110.8219 \quad 4235304 \quad 515580$

$\begin{array}{lllll}(D-30-11) 05 d b c & 38.2256 & 110.7383 & 4230672 & 522907 \\ (D-30-11) 05 d b c & 38.2256 & 110.7383 & 4230672 & 522907\end{array}$
43.6
43.3

23.0

21.5

86.

22.0

21.0
23.0
DEPTH STA FLOW LEVEL

(m) $(\mathrm{L} / \mathrm{min})$

$(L / m i n)$

REFERENCE

Kohler, 1979

Kohler, 1979

Kohler, 1979

WATSTORE

Goode, 1978

11772.0

13.6

3.6
379.6

-6.3 WATSTORE

Goode, 1978

WATSTORE 


\section{APPENDIX B \\ WATER CHEMISTRY INFORMATION FOR GEOTHERMAL WELLS AND SPRINGS IN UTAH}

asterisk denotes chemical analysis NOT following the heierarchy:

$$
\begin{aligned}
& \mathrm{Na}>\mathrm{K}>\mathrm{Li} \\
& \mathrm{Ca}>\mathrm{Mg}>\mathrm{Sr}>\mathrm{Ba} \\
& \mathrm{Cl}>\mathrm{F}>\mathrm{Br}>\mathrm{I}
\end{aligned}
$$




\begin{tabular}{|c|c|c|c|c|c|c|c|c|c|c|c|c|c|c|c|c|c|c|}
\hline ID & MAP NO. & $\mathrm{pH}$ & $\mathrm{Na}$ & $\mathrm{K}$ & $\mathrm{Ca}$ & $\mathrm{Mg}$ & $\mathrm{Fe}$ & $\mathrm{SiO} 2$ & B & $\mathrm{Li}$ & $\mathrm{HCO} 3$ & SO4 & $\mathrm{Cl}$ & $\mathbf{F}$ & TDSm & TDSC & $\begin{array}{c}C / A \quad \delta D \\
(z) \quad(q .)\end{array}$ & $\begin{array}{l}8018 \\
\left(\frac{8}{8} .\right)\end{array}$ \\
\hline 1 & $B E-01$ & 7.7 & 35 & 8.7 & 43.0 & 14.0 & 0.280 & 71 & & 0.1 & 118.0 & 44.0 & 42 & 3.10 & & 248 & 125 & \\
\hline 2 & $B E-02$ & 10.0 & 3460 & 225.0 & 26.4 & 12.0 & & 180 & 0.8 & & 1322.0 & 1280.0 & 2450 & 4.70 & 9405 & 8108 & 135 & \\
\hline 3 & $B E-03$ & $\begin{array}{l}7.7 \\
7.7\end{array}$ & 23 & 3.0 & 85.0 & 16.0 & & 42 & & & 196.0 & 27.0 & 97 & 0.20 & 397 & 348 & 101 & \\
\hline 4 & $B E-04$ & 7.7 & & & & & & & & & 264.0 & & 3200 & & & 3330 & & \\
\hline 5 & $B E-04$ & 6.1 & 1620 & 260.0 & 120.0 & 25.0 & & 46 & & 21.0 & 300.0 & 7.8 & 3640 & 2.50 & & 5823 & 79 & \\
\hline 6 & $B E-05$ & 7.9 & 2500 & 490.0 & 22.0 & & 0.040 & 310 & 4.0 & & 2560.0 & 73.0 & 4200 & 7.50 & 7840 & 8060 & 84 & \\
\hline 7 & $B E-05$ & 7.9 & 2500 & 488.0 & 22.0 & & & 146 & 38.0 & 0.3 & 156.0 & 73.0 & 4240 & 7.50 & 7800 & 7407 & 98 & \\
\hline 8 & $B E-05$ & 8.5 & 2100 & 470.0 & 19.0 & 3.3 & 0.040 & 400 & 3.0 & & 42.0 & 65.0 & 3800 & 7.10 & 7040 & 6485 & 95 & \\
\hline 9 & BE-05 & 5.6 & 1800 & 260.0 & 110.0 & 22.0 & & 165 & & & 298.0 & 110.0 & 3150 & 3.50 & & 5602 & 96 & \\
\hline 10 & $\star B E-06$ & 9.4 & 910 & 17.0 & 97.0 & 125.0 & 0.310 & 24 & & 6.5 & 326.0 & 14.0 & 1900 & 0.96 & & 3225 & 93 & \\
\hline 11 & $B E-07$ & 7.8 & 65 & 2.0 & 100.0 & 25.0 & & 26 & & & 254.0 & 52.0 & 130 & 0.18 & & 499 & 111 & \\
\hline 12 & $B E-08$ & 7.8 & 18 & 5.0 & 50.0 & 10.0 & & 48 & & & 167.0 & 40.0 & 53 & 0.36 & & 258 & 83 & \\
\hline 13 & BE-09 & 8.1 & 15 & 3.0 & 48.0 & 8.0 & & 14 & & & 169.0 & 12.0 & 19 & 0.24 & & 188 & 106 & \\
\hline 14 & $B E-10$ & 6.2 & 2200 & 410.0 & 6.9 & 0.1 & & 383 & 28.0 & & & 60.0 & 3650 & 4.80 & & 6332 & & \\
\hline 15 & $B E-10$ & 5.9 & 2150 & 390.0 & 9.2 & 0.6 & & 229 & 29.0 & & & 78.0 & 3650 & 5.20 & 6614 & 6283 & & \\
\hline 16 & $B E-11$ & & 2320 & 461.0 & 8.0 & & 0.030 & 263 & 29.9 & 25.3 & 232.0 & 72.0 & 3860 & 6.80 & 7504 & 6842 & 99 & \\
\hline 17 & $B E-11$ & & 2320 & 461.0 & 8.0 & 2.0 & 0.030 & 263 & 29.9 & 25.3 & 232.0 & 72.0 & 3860 & 6.80 & 7504 & 6844 & 99 & \\
\hline 18 & $B E-12$ & 5.8 & 1950 & 400.0 & 7.0 & 0.1 & & 590 & & & 200.0 & 61.0 & 3400 & 5.70 & & 5922 & 94 & \\
\hline 19 & $B E-13$ & 7.3 & 1780 & 440.0 & 69.1 & 1.0 & 0.370 & 178 & 28.2 & & 485.0 & 120.0 & 2860 & & & 5509 & 101 & \\
\hline 20 & $B E-14$ & 7.5 & 2000 & 400.0 & 12.2 & 0.3 & & 244 & 27.2 & 16.0 & 181.0 & 32.0 & 3260 & 6.80 & 6444 & 5800 & 102 & \\
\hline 21 & $B E-14$ & 7.5 & 2000 & 400.0 & 12.2 & 0.3 & & 244 & 27.2 & 16.0 & 181.0 & 32.0 & 3260 & 5.30 & 6444 & 5799 & 102 & \\
\hline 22 & $B E-15$ & 7.3 & 1900 & 218.0 & 114.0 & 3.9 & 6.900 & 67 & 27.0 & & 550.0 & 86.0 & 2885 & 3.40 & 5727 & 5488 & 102 & \\
\hline 23 & $B E-15$ & 6.8 & 1900 & 216.0 & 107.0 & 4.0 & 6.300 & 65 & 27.0 & & 615.0 & 85.0 & 2880 & 3.60 & 5677 & 5504 & 101 & \\
\hline 24 & $B E-16$ & 7.9 & 74 & 8.4 & 20.0 & 6.4 & & 70 & 0.2 & & 220.0 & 31.0 & 17 & 1.20 & 316 & 266 & 104 & \\
\hline 25 & $B E-16$ & 7.9 & 74 & 8.0 & 20.0 & 6.4 & & 70 & 0.2 & & 220.0 & 31.0 & 17 & 1.20 & 316 & 266 & 104 & \\
\hline 26 & $\mathrm{BE}-17$ & 7.6 & 28 & 1.0 & 48.0 & 28.0 & & 14 & & & 272.0 & 15.0 & 58 & 0.29 & & 312 & 92 & \\
\hline 27 & $B E-18$ & 7.8 & 63 & 3.0 & 47.0 & 19.0 & 0.010 & 25 & 0.2 & & 87.0 & 60.0 & 150 & 0.20 & 413 & 385 & 97 & \\
\hline 28 & $B E-19$ & 8.2 & 62 & 2.8 & 13.0 & 5.8 & & 35 & & & 160.0 & 40.0 & 16 & 0.60 & 253 & 219 & 99 & \\
\hline 29 & $B E-20$ & 8.0 & 29 & 2.2 & 33.0 & 5.7 & & 27 & & & 134.0 & 25.0 & 33 & 0.60 & & 194 & 94 & \\
\hline 30 & $B E-21$ & 8.0 & 67 & 3.2 & 89.0 & 37.0 & 0.008 & 25 & & & 136.0 & 240.0 & 83 & 0.41 & & 586 & 109 & \\
\hline 31 & $B E-22$ & 8.1 & 85 & 2.7 & 47.0 & 21.0 & 0.008 & 29 & & & 142.0 & 135.0 & 75 & 0.78 & & 436 & 108 & \\
\hline 32 & $B E-22$ & 8.0 & 88 & 3.0 & 61.0 & 31.0 & 0.010 & 31 & 0.2 & & 156.0 & 190.0 & 100 & 0.90 & 580 & 551 & 101 & \\
\hline 33 & $B E-23$ & & 56 & & & & & 34 & & & 164.0 & 37.0 & 10 & 1.00 & & 185 & & \\
\hline 34 & $B E-24$ & & & & & & & & & & 141.0 & & 14 & & 83 & 83 & 194 & \\
\hline 35 & $B E-25$ & 7.8 & 45 & 3.0 & 14.0 & 7.0 & 0.090 & 32 & 0.1 & & 132.0 & 28.0 & 26 & 0.60 & 211 & 189 & 95 & \\
\hline 36 & $B E-26$ & 7.4 & 100 & 5.0 & 120.0 & 73.0 & 0.010 & 44 & 0.3 & & 204.0 & 360.0 & 200 & 0.50 & 1020 & 959 & 99 & \\
\hline 37 & $B E-26$ & 7.9 & 32 & 3.0 & 55.0 & 30.0 & 0.030 & 32 & 0.1 & & 96.0 & 130.0 & 79 & 0.40 & 414 & 377 & 102 & \\
\hline 38 & $B E-27$ & & & & & & & & & & & & & & & & & \\
\hline 39 & $B E-28$ & 8.0 & 21 & 2.9 & 25.0 & 8.3 & 0.006 & 32 & & & 96.0 & 20.0 & 14 & 0.65 & & 139 & 122 & \\
\hline 40 & $B E-29$ & 7.9 & 72 & 4.9 & 64.0 & 23.0 & & 45 & 0.2 & & 200.0 & 130.0 & 86 & 0.90 & & 479 & 99 & \\
\hline 41 & $B E-30$ & 7.7 & 40 & & 27.0 & 9.0 & & 38 & & & 140.0 & 44.0 & 19 & & 249 & 208 & 102 & \\
\hline 42 & $\mathrm{BE}-30$ & 7.1 & 93 & 10.0 & 280.0 & 68.0 & 0.020 & 48 & 0.2 & & 304.0 & 620.0 & 230 & 0.30 & 1510 & 1451 & 97 & \\
\hline 43 & $B E-30$ & 7.7 & 40 & & 27.0 & 9.0 & & 38 & & & 144.0 & 44.0 & 19 & & & 210 & & \\
\hline 44 & $B E-31$ & & & & & & & & & & & & & & & & & \\
\hline 45 & $B E-32$ & 7.7 & 76 & 1.0 & 80.0 & 47.0 & 0.600 & 61 & 0.2 & & 265.0 & 40.0 & 220 & 0.60 & 720 & 596 & 98 & \\
\hline 46 & $B E-33$ & 7.7 & 28 & 1.0 & 103.0 & 18.0 & & 46 & & & 267.0 & 14.0 & 77 & 0.10 & & 372 & 114 & \\
\hline 47 & $B E-34$ & 7.9 & 20 & 8.0 & 31.0 & 5.0 & 0.010 & 75 & 0.1 & & 121.0 & 41.0 & 6 & 0.80 & 247 & 171 & 100 & \\
\hline 48 & $B E-35$ & & & & & & & & & & & & 20 & & 20 & 20 & & \\
\hline 49 & $\mathrm{BE}-36$ & 7.9 & & & 107.0 & 39.0 & & 69 & & & 498.0 & 93.0 & 75 & & 713 & 628 & 70 & \\
\hline 50 & $B E-37$ & & & & & & & & & & 293.0 & 35.0 & 40 & & 184 & 219 & & \\
\hline 51 & $B E-38$ & 7.5 & 38 & 6.0 & 120.0 & 25.0 & 0.010 & 38 & 0.2 & & 244.0 & 87.0 & 130 & 0.30 & 576 & 526 & 103 & \\
\hline 52 & $\mathrm{BE}-39$ & & & & & & & & & & & & & & & & & \\
\hline 53 & BE-39 & 8.1 & 37 & 3.1 & 18.0 & 7.8 & 0.007 & 29 & & & 97.0 & 39.0 & 11 & 0.52 & & 164 & 119 & \\
\hline
\end{tabular}




\begin{tabular}{|c|c|c|c|c|c|c|c|c|c|c|c|c|c|c|c|c|c|c|c|}
\hline ID & MAP NO. & $\mathrm{pH}$ & $\mathrm{Na}$ & $\mathrm{K}$ & $\mathrm{Ca}$ & Mg & $\mathrm{Fe}$ & $\mathrm{SiO} 2$ & B & Li & $\mathrm{HCO} 3$ & $\mathrm{SO} 4$ & Cl & F & TDSm & TDSC & $\begin{array}{c}C / A \\
(z)\end{array}$ & $\begin{array}{r}\delta D \\
\left(\frac{\delta}{2}\right)\end{array}$ & $\begin{array}{l}8018 \\
(8 .)\end{array}$ \\
\hline 54 & $B E-40$ & 7.7 & 190 & & 110.0 & 23.0 & & 32 & 0.4 & & 230.0 & 480.0 & 65 & 3.30 & 1030 & 1017 & 398 & & \\
\hline 55 & $\begin{array}{l}B E-41 \\
B E-41\end{array}$ & 7.4 & & 19.0 & 100.0 & 23.0 & & $\begin{array}{l}33 \\
37\end{array}$ & & 0.2 & 214.0 & 460.0 & & 3.00 & & 938 & 100 & & \\
\hline $\begin{array}{l}56 \\
57\end{array}$ & $\begin{array}{l}B E-41 \\
B E-41\end{array}$ & $\begin{array}{l}8.3 \\
7.7\end{array}$ & $\begin{array}{l}170 \\
178\end{array}$ & $\begin{array}{l}18.0 \\
15.0\end{array}$ & $\begin{array}{l}110.0 \\
110.0\end{array}$ & $\begin{array}{l}24.0 \\
20.0\end{array}$ & 0.020 & $\begin{array}{l}31 \\
32\end{array}$ & 0.3 & 0.2 & $\begin{array}{l}220.0 \\
221.0\end{array}$ & $\begin{array}{l}480.0 \\
400.0\end{array}$ & $\begin{array}{l}65 \\
83\end{array}$ & $\begin{array}{l}9.80 \\
2.60\end{array}$ & 1030 & $\begin{array}{l}985 \\
917\end{array}$ & $\begin{array}{r}99 \\
106\end{array}$ & & \\
\hline 58 & $B E-41$ & 7.4 & 170 & 17.0 & 88.0 & 35.0 & & 32 & 0.5 & & 228.0 & 440.0 & 63 & 4.50 & 1020 & 962 & & & \\
\hline 59 & $B E-42$ & 8.3 & 160 & 0.5 & 12.0 & 4.1 & 0.190 & 10 & 0.2 & & 251.0 & 69.0 & 90 & 1.40 & 475 & 461 & 97 & & \\
\hline $\begin{array}{l}60 \\
61\end{array}$ & $\begin{array}{l}B E-43 \\
B E-44\end{array}$ & $\begin{array}{l}8.0 \\
7.5\end{array}$ & $\begin{array}{l}49 \\
38\end{array}$ & $\begin{array}{l}2.8 \\
5.0\end{array}$ & $\begin{array}{l}79.0 \\
34.0\end{array}$ & $\begin{array}{r}13.0 \\
8.8\end{array}$ & $\begin{array}{l}0.010 \\
0.010\end{array}$ & $\begin{array}{l}40 \\
47\end{array}$ & $\begin{array}{l}0.1 \\
0.1\end{array}$ & & $\begin{array}{l}308.0 \\
144.0\end{array}$ & $\begin{array}{l}25.0 \\
50.0\end{array}$ & $\begin{array}{l}60 \\
25\end{array}$ & $\begin{array}{l}0.30 \\
0.30\end{array}$ & $\begin{array}{l}421 \\
291\end{array}$ & $\begin{array}{l}381 \\
232\end{array}$ & $\begin{array}{r}99 \\
102\end{array}$ & & \\
\hline 62 & $\mathrm{BE}-45$ & 8.2 & 65 & 2.3 & 7.3 & 1.2 & & 46 & 0.2 & & 117.0 & 34.0 & 36 & 0.90 & & 204 & 91 & & \\
\hline $\begin{array}{l}63 \\
64\end{array}$ & $\begin{array}{l}B E-46 \\
B E-46\end{array}$ & $\begin{array}{l}7.0 \\
8.1\end{array}$ & $\begin{array}{l}371 \\
360\end{array}$ & $\begin{array}{l}50.0 \\
49.0\end{array}$ & $\begin{array}{l}69.0 \\
83.0\end{array}$ & $\begin{array}{r}10.0 \\
9.7\end{array}$ & $\begin{array}{l}0.040 \\
0.130\end{array}$ & $\begin{array}{r}84 \\
110\end{array}$ & $\begin{array}{l}1.0 \\
0.6\end{array}$ & 1.2 & $\begin{array}{l}401.0 \\
384.0\end{array}$ & $\begin{array}{l}460.0 \\
480.0\end{array}$ & $\begin{array}{l}222 \\
210\end{array}$ & $\begin{array}{r}6.00 \\
14.00\end{array}$ & $\begin{array}{l}1495 \\
1500\end{array}$ & $\begin{array}{l}1385 \\
1395\end{array}$ & $\begin{array}{l}96 \\
98\end{array}$ & -118.0 & -14.3 \\
\hline 65 & $\mathrm{BE}-46$ & 7.4 & 379 & 51.0 & 85.0 & 10.0 & 0.040 & 89 & 1.0 & 1.2 & 401.0 & 475.0 & 220 & 5.60 & 1518 & 1423 & 100 & -118.0 & -14.3 \\
\hline 67 & $B E-46$ & 6.8 & 378 & 52.0 & 78.0 & 10.0 & 0.020 & $\begin{array}{r}87 \\
113\end{array}$ & 1.0 & 1.3 & 401.0 & 476.0 & 222 & 6.50 & 1564 & 1420 & 98 & -118.0 & -14.3 \\
\hline $\begin{array}{l}68 \\
69\end{array}$ & $\begin{array}{l}B E-46 \\
B E-47\end{array}$ & $\begin{array}{l}8.0 \\
8.0\end{array}$ & $\begin{array}{l}380 \\
380\end{array}$ & $\begin{array}{l}52.0 \\
52.0\end{array}$ & $\begin{array}{l}71.0 \\
71.0\end{array}$ & $\begin{array}{l}10.0 \\
10.0\end{array}$ & 0.020 & $\begin{array}{l}113 \\
113\end{array}$ & 0.9 & 1.3 & $\begin{array}{l}360.0 \\
360.0\end{array}$ & $\begin{array}{l}480.0 \\
480.0\end{array}$ & $\begin{array}{l}225 \\
255\end{array}$ & $\begin{array}{l}6.60 \\
6.60\end{array}$ & & $\begin{array}{l}1402 \\
1432\end{array}$ & $\begin{array}{l}99 \\
96\end{array}$ & -118.0 & -14.3 \\
\hline 70 & $B E-47$ & 7.6 & 390 & 54.0 & 70.0 & 10.0 & & 72 & & 1.5 & 324.0 & 260.0 & 190 & 4.70 & & 1138 & 240 & & \\
\hline 71 & $B E-47$ & 8.0 & 360 & 53.0 & 73.0 & 9.0 & 0.008 & 111 & & 1.4 & 344.0 & 404.0 & 200 & 5.40 & & 1274 & 108 & & \\
\hline 72 & $B E-47$ & 7.4 & 360 & 47.0 & 76.0 & 12.0 & & 10 & 0.9 & & 374.0 & 460.0 & 210 & 14.00 & 2490 & 1363 & 100 & & \\
\hline 73 & $B E-48$ & 7.8 & 73 & 5.0 & 110.0 & 42.0 & & 16 & & 0.2 & 188.0 & 160.0 & 184 & 0.50 & -200 & 667 & 105 & & \\
\hline 74 & $B E-49$ & 7.7 & 340 & 19.0 & 190.0 & 69.0 & & 60 & & 0.3 & 320.0 & 140.0 & 1510 & 0.91 & & 2426 & 59 & & \\
\hline $\begin{array}{l}75 \\
76\end{array}$ & $\begin{array}{r}\mathrm{BO}-01 \\
* \mathrm{BO}-02\end{array}$ & & $\begin{array}{l}29000 \\
67000\end{array}$ & $\begin{array}{l}1500.0 \\
4300.0\end{array}$ & $\begin{array}{l}1200.0 \\
1200.0\end{array}$ & $\begin{array}{r}500.0 \\
2400.0\end{array}$ & & & $\begin{array}{l}1.1 \\
3.5\end{array}$ & $\begin{array}{l}14.0 \\
38.0\end{array}$ & $\begin{array}{r}73.0 \\
190.0\end{array}$ & $\begin{array}{l}2200.0 \\
2300.0\end{array}$ & $\begin{array}{r}50000 \\
110000\end{array}$ & & $\begin{array}{r}87000 \\
192000\end{array}$ & $\begin{array}{r}84436 \\
186293\end{array}$ & $\begin{array}{r}96 \\
101\end{array}$ & & \\
\hline 77 & $\star \mathrm{BO}-03$ & & 98000 & 6900.0 & 2200.0 & 2400.0 & & & 2.5 & 69.0 & 110.0 & 3300.0 & 170000 & & 288000 & 282854 & $\begin{array}{r}101 \\
97\end{array}$ & & \\
\hline 78 & BO- 04 & 7.7 & 1300 & 41.0 & 95.0 & 75.0 & 0.480 & 14 & & & 175.0 & 230.0 & 2200 & 0.60 & 4050 & 4028 & 98 & & \\
\hline 79 & $B O-05$ & 7.7 & 440 & 9.8 & 81.0 & 36.0 & & 13 & 0.1 & & 242.0 & 76.0 & 750 & 0.40 & 1520 & 1512 & 98 & & \\
\hline $\begin{array}{l}80 \\
81\end{array}$ & $\begin{array}{l}B O-06 \\
B O-07\end{array}$ & $\begin{array}{l}7.2 \\
7.9\end{array}$ & $\begin{array}{l}110 \\
216\end{array}$ & 17.0 & $\begin{array}{l}41.0 \\
75.0\end{array}$ & $\begin{array}{r}5.6 \\
10.0\end{array}$ & 0.360 & $\begin{array}{l}39 \\
16\end{array}$ & 0.4 & & $\begin{array}{l}430.0 \\
169.0\end{array}$ & $\begin{array}{l}6.0 \\
8.5\end{array}$ & $\begin{array}{r}22 \\
390\end{array}$ & 1.00 & $\begin{array}{l}474 \\
866\end{array}$ & $\begin{array}{l}414 \\
783\end{array}$ & 99 & & \\
\hline 82 & BO-07 & 7.9 & 65 & 3.0 & 10.0 & 1.0 & 0.140 & 15 & 0.1 & & 133.0 & 8.0 & 41 & 0.40 & 210 & 194 & 99 & & \\
\hline 83 & BO-07 & 7.9 & 220 & & 75.0 & 10.0 & & 16 & & & 170.0 & 9.0 & 390 & & 866 & 788 & 101 & & \\
\hline 84 & BO- 08 & 7.5 & 6580 & 935.0 & 1020.0 & 39.0 & 0.314 & 35 & 3.1 & 7.9 & 182.0 & 201.0 & 12700 & 4.30 & 21600 & 21569 & 99 & & \\
\hline $\begin{array}{l}85 \\
86\end{array}$ & $\begin{array}{l}\text { BO-09 } \\
\text { BO-10 }\end{array}$ & $\begin{array}{l}7.8 \\
7.8\end{array}$ & $\begin{array}{l}90 \\
49\end{array}$ & 6.8 & $\begin{array}{l}18.0 \\
21.0\end{array}$ & $\begin{array}{l}1.5 \\
4.4\end{array}$ & & $\begin{array}{l}61 \\
28\end{array}$ & 0.1 & & $\begin{array}{l}279.0 \\
193.0\end{array}$ & $\begin{array}{l}0.8 \\
4.5\end{array}$ & 12 & & & 259 & & & \\
\hline 87 & BO-11 & 7.7 & 140 & 27.0 & 41.0 & 3.6 & 0.120 & 21 & 0.5 & & 330.0 & $\begin{array}{l}4.5 \\
3.0\end{array}$ & $\begin{array}{r}10 \\
160\end{array}$ & $\begin{array}{l}0.50 \\
1.20\end{array}$ & $\begin{array}{l}221 \\
560\end{array}$ & $\begin{array}{l}191 \\
538\end{array}$ & $\begin{array}{r}104 \\
91\end{array}$ & & \\
\hline 88 & $\mathrm{BO}-12$ & & & & & & & & & & & & 13100 & & 24900 & 13100 & & & \\
\hline 89 & BO- 13 & 7.2 & 340 & 65.0 & 200.0 & 72.0 & 0.010 & 53 & & & 681.0 & 0.5 & 730 & 0.20 & 1980 & 1743 & 101 & & \\
\hline $\begin{array}{l}90 \\
91\end{array}$ & & 7.7 & 2180 & 43.0 & $\begin{array}{l}92.0 \\
56.0\end{array}$ & 54.0 & & 15 & 0.6 & & 246.0 & 176.0 & 1950 & 1.00 & $\begin{array}{l}3750 \\
3350\end{array}$ & 3617 & 98 & & \\
\hline $\begin{array}{l}91 \\
92\end{array}$ & $\begin{array}{r}B O-15 \\
* B O-15\end{array}$ & & $\begin{array}{l}1000 \\
1000\end{array}$ & 110.0 & $\begin{array}{l}56.0 \\
56.0\end{array}$ & 62.0 & & & & & $\begin{array}{l}1620.0 \\
1620.0\end{array}$ & 14.0 & $\begin{array}{l}1100 \\
1100\end{array}$ & & $\begin{array}{l}3350 \\
3350\end{array}$ & 3139 & 94 & & \\
\hline $\begin{array}{l}93 \\
94\end{array}$ & $\begin{array}{l}\text { BO- } 16 \\
\text { BO-17 }\end{array}$ & & & & & & & & & & & & & & & & & & \\
\hline $\begin{array}{l}94 \\
95\end{array}$ & $\begin{array}{l}\text { BO- } 17 \\
\text { BO- } 18\end{array}$ & 7.7 & 3900 & 160.0 & $\begin{array}{r}94.0 \\
\end{array}$ & $\begin{array}{r}45.0 \\
\end{array}$ & & 80 & 0.6 & & 452.0 & $\begin{array}{r}170.0 \\
59.0\end{array}$ & $\begin{array}{r}6200 \\
21000\end{array}$ & 1.20 & 10800 & 10792 & 98 & & \\
\hline $\begin{array}{l}95 \\
96\end{array}$ & $\begin{array}{l}\mathrm{BO}-18 \\
\mathrm{BO}-18\end{array}$ & $\begin{array}{l}6.4 \\
7.1\end{array}$ & $\begin{array}{l}11000 \\
10000\end{array}$ & $\begin{array}{l}670.0 \\
500.0\end{array}$ & $\begin{array}{l}920.0 \\
660.0\end{array}$ & $\begin{array}{l}360.0 \\
440.0\end{array}$ & $\begin{array}{l}0.010 \\
0.020\end{array}$ & $\begin{array}{l}54 \\
42\end{array}$ & 3.3 & & $\begin{array}{l}528.0 \\
440.0\end{array}$ & $\begin{array}{r}59.0 \\
160.0\end{array}$ & $\begin{array}{l}21000 \\
18000\end{array}$ & 1.80 & $\begin{array}{l}34600 \\
30100\end{array}$ & $\begin{array}{l}34269 \\
29978\end{array}$ & $\begin{array}{l}94 \\
99\end{array}$ & & \\
\hline $\begin{array}{l}97 \\
98\end{array}$ & $\begin{array}{l}B O-19 \\
B O-20\end{array}$ & & & & & & & & & & & & & & & & & & \\
\hline 99 & $B O-21$ & & & & & & & & & & & & & & & & & & \\
\hline 100 & & & & 450.0 & & 230.0 & 0.800 & 28 & 0.4 & & 400.0 & 500.0 & & 1.50 & 37000 & 37009 & 98 & & \\
\hline 101 & $\mathrm{BO}-23$ & 7.5 & 96 & 23.0 & 82.0 & 33.0 & 0.040 & 65 & 0.1 & & 176.0 & 38.0 & 260 & 0.80 & 852 & 619 & 105 & & \\
\hline 102 & BO- 24 & 7.6 & 77 & & 63.0 & 21.0 & & 19 & & & 184.0 & 29.0 & 162 & & 501 & 442 & & & \\
\hline 103 & BO-25 & & & & & & & & & & & & & & & & & & \\
\hline $\begin{array}{l}104 \\
105\end{array}$ & $\begin{array}{l}\text { BO-26 } \\
\text { BO-27 }\end{array}$ & 7.6 & 25 & 5.7 & 50.0 & 8.3 & & 47 & & & 154.0 & 18.0 & 50 & 0.40 & 304 & 233 & 102 & & \\
\hline 106 & $\mathrm{BO}-28$ & & & & & & & & & & & & & & & & & & \\
\hline
\end{tabular}




\begin{tabular}{|c|c|c|c|c|c|c|c|c|c|c|c|c|c|c|c|c|c|c|c|}
\hline ID & MAP NO. & $\mathrm{pH}$ & $\mathrm{Na}$ & $\kappa$ & $\mathrm{Ca}$ & $\mathrm{Mg}$ & $\mathrm{Fe}$ & $\mathrm{SiO} 2$ & B & $\mathrm{L} \dot{j}$ & $\mathrm{HCO} 3$ & $\mathrm{SO} 4$ & $\mathrm{Cl}$ & F & TDSm & TDSC & $\underset{(8)}{C / A}$ & $\begin{array}{r}\delta D \\
\left(\frac{q}{\partial} .\right)\end{array}$ & $\begin{array}{l}8018 \\
(8 .)\end{array}$ \\
\hline $\begin{array}{l}107 \\
108\end{array}$ & $\begin{array}{l}\text { BO- } 29 \\
B O-29\end{array}$ & 7.1 & $\begin{array}{l}15800 \\
15000\end{array}$ & 720.0 & 840.0 & $\begin{array}{l}130.0 \\
230.0\end{array}$ & 4.700 & 22 & 5.0 & & 400.0 & 300.0 & 28100 & 1.50 & & 46093 & $\begin{array}{l}94 \\
97\end{array}$ & -110.0 & -13.1 \\
\hline 109 & $\mathrm{BO}-30$ & & 15000 & 790.0 & 830.0 & 230.0 & & 32 & & & 479.0 & 480.0 & 26000 & & 43600 & 43566 & & & \\
\hline 110 & $\mathrm{BO}-31$ & & & & & & & & & & & & & & & & & & \\
\hline 111 & $\mathrm{BO}-32$ & 7.5 & 13 & & 44.0 & 14.0 & & 24 & & & 184.0 & 29.0 & 9 & & 248 & 200 & & & \\
\hline 122 & $B O-33$ & 7.8 & 90 & 6.0 & 48.0 & 20.0 & & 5 & 0.1 & & 180.0 & 60.0 & 150 & 0.24 & & 463 & 96 & -143.0 & -16.0 \\
\hline 113 & BO- 34 & & & & & & & & & & & & & & & & & & \\
\hline $\begin{array}{l}114 \\
115\end{array}$ & $\begin{array}{l}\text { BO- } 35 \\
B O-36\end{array}$ & 7.1 & & & & & & & & & & & & & & & & & \\
\hline 116 & BO- 37 & 8.2 & 54 & & 81.0 & 12.0 & & & & & 250.0 & & 100 & & 477 & 370 & & & \\
\hline 117 & BO- 38 & 6.5 & 1527 & 82.0 & 160.0 & 76.0 & & 37 & 0.6 & 0.5 & 376.0 & 327.0 & 2460 & 1.40 & 4724 & 4818 & 100 & & \\
\hline 118 & $B O-39$ & 8.5 & 27 & 1.7 & 36.0 & 8.0 & & 14 & & & 108.0 & 15.0 & 57 & 0.20 & 223 & 198 & 99 & & \\
\hline 119 & $B O-40$ & 7.6 & 620 & 22.0 & 84.0 & 43.0 & & 17 & & & 320.0 & 65.0 & 1000 & 1.00 & 2120 & 1992 & 102 & & \\
\hline $\begin{array}{l}120 \\
121\end{array}$ & $\begin{array}{l}B O-40 \\
B O-41\end{array}$ & 7.6 & 1900 & 65.0 & 155.0 & 60.0 & 0.100 & 17 & 0.6 & & 265.0 & 60.0 & 3400 & 1.00 & & 5771 & 95 & & \\
\hline 122 & $30-42$ & 7.2 & 2900 & 120.0 & 220.0 & 70.0 & 0.220 & 29 & & & 360.0 & 98.0 & 4800 & 0.40 & 8420 & 8386 & 101 & & \\
\hline 123 & BO- 42 & 7.7 & 2800 & 130.0 & 205.0 & 60.0 & 0.100 & 24 & 1.0 & & 300.0 & 100.0 & 4700 & 1.40 & & 8144 & 100 & -113.0 & -15.3 \\
\hline 124 & BO- 43 & 7.7 & 685 & 24.0 & 60.0 & 19.0 & & 20 & 0.2 & & 260.0 & 50.0 & 1000 & 2.40 & & 1968 & 104 & -134.0 & -16.1 \\
\hline 125 & BO -43 & 7.9 & 636 & 22.0 & 56.0 & 24.0 & & 19 & 0.2 & & 329.0 & 84.0 & 895 & 0.40 & 2010 & 1898 & 102 & & \\
\hline 126 & $80-44$ & 7.7 & 130 & 9.0 & 79.0 & 41.0 & 0.080 & 81 & 0.1 & & 341.0 & 38.0 & 240 & 1.30 & 787 & 706 & 100 & & \\
\hline 127 & BO- 44 & 8.4 & 153 & & 89.0 & $\begin{array}{l}41.0 \\
21.0\end{array}$ & & & & & 343.0 & & 274 & & 1010 & 726 & & & \\
\hline 128 & BO- 45 & 7.6 & 35 & 11.0 & 73.0 & $\begin{array}{l}21.0 \\
39.0\end{array}$ & & 60 & 0.1 & & 150.0 & 19.0 & 140 & 0.30 & 448 & 373 & 105 & & \\
\hline 129 & $B O-46$ & 7.4 & 614 & 21.0 & 95.0 & $\begin{array}{l}39.0 \\
27.0\end{array}$ & & 26 & 0.3 & 0.2 & 250.0 & 60.0 & 752 & 1.40 & 2264 & 1705 & 132 & & \\
\hline 130 & BO -47 & 7.2 & 106 & 13.0 & 50.0 & 27.0 & & 89 & 0.2 & & 242.0 & 111.0 & 62 & 0.80 & 614 & 489 & 120 & & \\
\hline 131 & BO- 48 & 7.2 & 102 & 22.0 & 85.0 & 25.0 & & 87 & 0.2 & & 167.0 & 47.0 & 223 & 0.40 & 774 & 577 & 110 & & \\
\hline 132 & BO-49 & 6.7 & 740 & 26.0 & 180.0 & 70.0 & & 49 & 0.2 & 0.2 & 217.0 & 83.0 & 1460 & 0.40 & 2744 & 2666 & 102 & & \\
\hline 133 & BO- 50 & 8.0 & 44 & 0.6 & 39.0 & 11.0 & & 10 & & & 156.0 & 19.0 & 65 & 0.20 & 274 & 256 & 99 & & \\
\hline 134 & $B O-52$ & 8.0 & 250 & 3.2 & 44.0 & 10.0 & & 15 & 0.5 & & 588.0 & 39.0 & 125 & 1.00 & 795 & 761 & 99 & & \\
\hline 135 & BO- 52 & 8.1 & 52 & 1.5 & 24.0 & 21.0 & & 12 & 0.2 & & 208.0 & 20.0 & 49 & 0.50 & 292 & 270 & 100 & & \\
\hline 136 & BO- 53 & 8.9 & 290 & 3.2 & 28.0 & 17.0 & & 1 & 0.6 & & 578.0 & 31.0 & 148 & 1.10 & 918 & 803 & 108 & & \\
\hline 137 & BO- 54 & 7.2 & 43 & 2.9 & 45.0 & 12.0 & & 11 & 0.1 & & 150.0 & 20.0 & 76 & 0.50 & 314 & 273 & 103 & & \\
\hline 138 & BO- 55 & 8.0 & 20 & 1.0 & 54.0 & 8.3 & & 10 & & & 187.0 & 8.8 & 36 & 0.10 & 240 & 220 & 100 & & \\
\hline 139 & BO- 56 & 8.3 & 213 & & 67.0 & 25.0 & & & & & 258.0 & & 341 & & 870 & 773 & & & \\
\hline 140 & BO- 57 & 7.1 & 236 & 9.0 & 198.0 & 48.0 & 0.220 & 19 & & 0.1 & 225.0 & 52.0 & 483 & 1.30 & 1034 & 1138 & 132 & & \\
\hline 141 & $B O-58$ & 6.8 & 279 & 10.0 & 124.0 & 43.0 & 0.120 & 17 & & 0.1 & 217.0 & 44.0 & 513 & 1.30 & 1148 & 1121 & 116 & & \\
\hline $\begin{array}{l}142 \\
143\end{array}$ & $\begin{array}{l}\mathrm{BO}-59 \\
\mathrm{BO}-60\end{array}$ & & & & & & & & & & & & & & & & & & \\
\hline $\begin{array}{l}143 \\
144\end{array}$ & $B O-61$ & & & & & & & & & & & & & & & & & & \\
\hline $\begin{array}{l}145 \\
146\end{array}$ & BO- 62 & & & & & & & & & & & & & & & & & & \\
\hline $\begin{array}{l}146 \\
147\end{array}$ & $\begin{array}{l}\text { BO }-63 \\
\text { BO- } 63\end{array}$ & 7.0 & 503 & 29.0 & 269.0 & 68.0 & & 76 & & 0.1 & 301.0 & 315.0 & 876 & 1.00 & 2434 & 2209 & 115 & & \\
\hline 148 & BO- 63 & & & & & & & & & & & & & & & & & & \\
\hline 249 & $\mathrm{BO}-64$ & 7.2 & 123 & & 146.0 & 35.0 & & 61 & & & 186.0 & 34.0 & 426 & & 921 & 855 & & & \\
\hline $\begin{array}{l}150 \\
151\end{array}$ & $\begin{array}{l}\text { BO- } 65 \\
\text { BO- } 66\end{array}$ & 6.7 & 48 & 13.0 & 117.0 & 24.0 & & 73 & & & 209.0 & 23.0 & 172 & 0.30 & 603 & 500 & 116 & & \\
\hline 152 & $B O-67$ & 6.6 & 133 & 14.0 & 84.0 & 34.0 & 0.060 & 71 & 0.2 & 0.1 & 275.0 & 44.0 & 289 & 0.40 & 870 & 734 & 96 & & \\
\hline 153 & $B O-68$ & & & & & & & & & & & & & & & & & & \\
\hline $\begin{array}{l}154 \\
155\end{array}$ & BO- 69 & & & & & & & & & & & & & & & & & & \\
\hline $\begin{array}{l}155 \\
156\end{array}$ & $\mathrm{BO}-70$ & & $25 ?$ & & 620 & 170 & 0040 & 17 & $0 ?$ & $0 ?$ & 2840 & 370 & 305 & 070 & 2077 & 831 & 123 & & \\
\hline $\begin{array}{l}156 \\
157\end{array}$ & $\begin{array}{l}\text { BO-70 } \\
\text { BO-71 }\end{array}$ & 6.7 & 253 & 16.0 & 63.0 & 17.0 & 0.040 & 41 & 0.2 & 0.2 & 284.0 & 37.0 & 305 & 0.70 & 2072 & 831 & 113 & & \\
\hline 158 & BO-72 & 7.6 & 1070 & 56.0 & 87.0 & 19.0 & & 29 & 0.8 & & 352.0 & 78.0 & 1620 & 2.70 & 3240 & 3106 & 101 & & \\
\hline 159 & BO- 72 & 7.1 & 1111 & 73.0 & 82.0 & 17.0 & & 33 & 1.0 & 0.9 & 351.0 & 63.0 & 1660 & 2.40 & 3168 & 3181 & 103 & & \\
\hline
\end{tabular}




\begin{tabular}{|c|c|c|c|c|c|c|c|c|c|c|c|c|c|c|c|c|c|c|}
\hline ID & MAP NO. & $\mathrm{pH}$ & $\mathrm{Na}$ & $\mathrm{K}$ & $\mathrm{Ca}$ & $\mathrm{Mg}$ & $\mathrm{Fe}$ & $\mathrm{SiO} 2$ & B & $L i$ & $\mathrm{HCO} 3$ & SO4 & $\mathrm{Cl}$ & $F$ & TDSm & TDSC & $\begin{array}{c}C / A \quad \delta D \\
(\xi)(z .)\end{array}$ & $\begin{array}{c}\delta 018 \\
(\xi .)\end{array}$ \\
\hline $\begin{array}{l}160 \\
161\end{array}$ & $\begin{array}{l}B O-73 \\
B O-74\end{array}$ & $\begin{array}{l}7.9 \\
6.8\end{array}$ & $\begin{array}{l}247 \\
159\end{array}$ & $\begin{array}{l}5.7 \\
5.0\end{array}$ & $\begin{array}{l}60.0 \\
76.0\end{array}$ & $\begin{array}{l}25.0 \\
33.0\end{array}$ & & $\begin{array}{l}41 \\
19\end{array}$ & 0.1 & & $\begin{array}{l}259.0 \\
326.0\end{array}$ & $\begin{array}{l}40.0 \\
44.0\end{array}$ & $\begin{array}{l}375 \\
303\end{array}$ & $\begin{array}{l}1.00 \\
1.20\end{array}$ & $\begin{array}{l}938 \\
764\end{array}$ & $\begin{array}{l}881 \\
781\end{array}$ & $\begin{array}{r}101 \\
91\end{array}$ & \\
\hline $\begin{array}{l}161 \\
162\end{array}$ & BO-75 & $\begin{array}{l}6.8 \\
7.1\end{array}$ & $\begin{array}{l}159 \\
179\end{array}$ & $\begin{array}{l}5.0 \\
5.0\end{array}$ & $\begin{array}{l}76.0 \\
78.0\end{array}$ & 34.0 & & 19 & & & $\begin{array}{l}326.0 \\
275.0\end{array}$ & $\begin{array}{l}44.0 \\
37.0\end{array}$ & 311 & $\begin{array}{l}1.20 \\
0.90\end{array}$ & $\begin{array}{l}764 \\
774\end{array}$ & $\begin{array}{l}781 \\
780\end{array}$ & $\begin{array}{r}91 \\
103\end{array}$ & \\
\hline 163 & BO- 76 & 7.3 & 120 & 5.0 & 94.0 & 46.0 & 0.040 & 19 & 0.1 & & 180.0 & 28.0 & 360 & 0.10 & 762 & 742 & 100 & \\
\hline 164 & $\mathrm{BO}-75$ & 6.8 & 138 & 4.0 & 97.0 & 41.0 & & 23 & & & 267.0 & 35.0 & 359 & 0.20 & 846 & 805 & 94 & \\
\hline 165 & BO- 77 & 7.1 & 540 & 42.0 & 400.0 & 110.0 & 0.020 & 79 & 0.1 & & 130.0 & 46.0 & 1800 & 0.20 & 3090 & 3002 & 99 & \\
\hline 166 & BO- 77 & 6.7 & 610 & 40.0 & 503.0 & 132.0 & & 81 & & 0.1 & 192.0 & 56.0 & 1980 & 0.90 & 5168 & 3416 & 105 & \\
\hline $\begin{array}{l}167 \\
168\end{array}$ & $\begin{array}{l}\text { BO- } 77 \\
\text { BO-78 }\end{array}$ & & & & & & & & & & 144.0 & 35.0 & 1500 & & 2640 & 2551 & 102 & \\
\hline 169 & BO-79 & & & & & & & & & & & & & & & & & \\
\hline $\begin{array}{l}170 \\
171\end{array}$ & $\begin{array}{l}B O-80 \\
B O-81\end{array}$ & 7.8 & 31 & & 70.0 & 17.0 & & 63 & & & 181.0 & 20.0 & 99 & & 432 & 326 & & \\
\hline $\begin{array}{l}172 \\
173\end{array}$ & BO- 82 & & 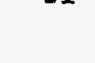 & & & 17.0 & & & & & 201.0 & & & & & & & \\
\hline $\begin{array}{l}173 \\
174\end{array}$ & $\begin{array}{l}\text { BO- } 83 \\
\text { BO-84 }\end{array}$ & & & & & & & & & & & & & & & & & \\
\hline 175 & $\mathrm{BO}-85$ & & & & & & & & & & & & & & & & & \\
\hline 176 & BO- 85 & 6.9 & 509 & 9.0 & 69.0 & 28.0 & 0.690 & 25 & 0.2 & 0.2 & 225.0 & 54.0 & 793 & 0.40 & 1638 & 1574 & 103 & \\
\hline $\begin{array}{l}177 \\
178\end{array}$ & $\begin{array}{l}\mathrm{CA}-01 \\
\mathrm{CA}-02\end{array}$ & & & & & & & & & & & & & & & & & \\
\hline 179 & $\mathrm{CA}-03$ & 7.4 & & & 56.0 & 26.0 & & 17 & & & 327.0 & 16.0 & 12 & & 336 & 288 & 82 & \\
\hline 180 & $\mathrm{CA}-04$ & 7.5 & 18 & & 55.0 & 21.0 & 0.010 & 28 & & 0.1 & 306.0 & 10.0 & 6 & 0.30 & 293 & 261 & 97 & \\
\hline & $\mathrm{CA}-05$ & & & & & & & & & & & & & & & & & \\
\hline $\begin{array}{l}182 \\
183\end{array}$ & $\begin{array}{l}C A-06 \\
C A-07\end{array}$ & & & & & & & & & & & & & & & & & \\
\hline $\begin{array}{l}184 \\
\end{array}$ & $\mathrm{CA}-08$ & & & & & & & & & & & & & & & & & \\
\hline 185 & $\mathrm{CA}-09$ & & & & & & & & & & & & & & & & & \\
\hline 386 & $C A-10$ & & & & & & & & & & & & & & & & & \\
\hline 187 & $C A-11$ & & & & & & & & & & & & & & & & & \\
\hline 188 & $C A-12$ & 7.2 & 22 & 6.0 & 51.0 & 20.0 & 0.100 & 18 & & & 247.0 & 21.0 & 20 & 0.30 & 290 & 262 & 105 & \\
\hline $\begin{array}{l}190 \\
191\end{array}$ & $\begin{array}{l}C A-14 \\
C A-15\end{array}$ & & & & 52.0 & & 0.010 & & & & & & & & & & & \\
\hline $\begin{array}{l}191 \\
192\end{array}$ & $\begin{array}{l}C A-15 \\
C A-16\end{array}$ & $\begin{array}{l}7.6 \\
6.8\end{array}$ & $\begin{array}{r}18 \\
204\end{array}$ & 4.9 & 42.0 & 36.0 & & $\begin{array}{l}20 \\
13\end{array}$ & 0.4 & & $\begin{array}{l}261.0 \\
286.0\end{array}$ & 18.0 & 11 & 0.20 & 261 & 248 & 101 & \\
\hline 193 & $\mathrm{CA}-17$ & 7.7 & 95 & & 55.0 & 17.0 & 0.670 & 27 & 0.4 & 0.1 & $\begin{array}{l}200.0 \\
374.0\end{array}$ & 1.0 & $\begin{array}{r}342 \\
98\end{array}$ & 0.30 & $\begin{array}{l}789 \\
469\end{array}$ & $\begin{array}{l}450 \\
450\end{array}$ & $\begin{array}{l}98 \\
93\end{array}$ & \\
\hline 194 & $C A-18$ & 7.2 & 81 & 5.0 & 56.0 & 19.0 & 0.600 & 48 & & & 340.0 & 2.0 & 200 & 0.80 & 478 & 432 & 95 & \\
\hline 195 & $C A-18$ & & & & & & & & & & & & & & & & & \\
\hline 196 & $\mathrm{CA}-19$ & & & & & & & & & & & & & & & & & \\
\hline 197 & $\mathrm{CA}-20$ & 7.2 & 68 & 3.0 & 51.0 & 16.0 & 0.100 & 57 & & & 308.0 & 2.0 & 76 & 0.80 & 424 & 368 & 95 & \\
\hline 198 & $\mathrm{CA}-21$ & 7.9 & 107 & & 128.0 & 53.0 & & 24 & & & 250.0 & 1.0 & 400 & & 1010 & 836 & 100 & \\
\hline 199 & $\mathrm{CA}-22$ & 8.1 & 1140 & 71.0 & 34.0 & 30.0 & & 81 & 2.7 & & 622.0 & 1.0 & 1690 & 4.50 & 3360 & 3360 & 96 & \\
\hline 200 & $C A-23$ & 6.9 & 1300 & 78.0 & 79.0 & 30.0 & 0.300 & 69 & & & 580.0 & 2.0 & 2120 & 4.50 & 3784 & 3899 & 93 & \\
\hline 201 & $\mathrm{CA}-24$ & & 182 & 6.1 & 44.0 & 31.0 & & 24 & 0.8 & & 358.0 & 1.0 & 255 & 0.30 & 720 & 720 & 98 & \\
\hline $\begin{array}{l}202 \\
203\end{array}$ & $\mathrm{CA}-25$ & & & & & & & & & & & & & & & & & \\
\hline 203 & $\mathrm{CA}-26$ & 7.2 & 110 & 4.0 & 89.0 & 29.0 & 0.800 & 33 & & & 236.0 & 1.0 & 298 & 0.20 & 766 & 648 & 95 & \\
\hline 204 & $\mathrm{CA}-27$ & 7.2 & 110 & 5.0 & 130.0 & 56.0 & 0.300 & 24 & & & 233.0 & 2.0 & 440 & 0.20 & 1060 & 858 & 98 & \\
\hline 205 & $C A-28$ & 7.3 & 1500 & 130.0 & 130.0 & 41.0 & 0.200 & 20 & & & 501.0 & 58.0 & 2400 & 2.30 & 4466 & 4508 & 101 & \\
\hline 206 & $\mathrm{CA}-28$ & 7.6 & 1400 & 110.0 & 132.0 & 46.0 & & 23 & 0.7 & & 548.0 & 71.0 & 2280 & 3.20 & 4380 & 4335 & 99 & \\
\hline 207 & CR-OI & 7.6 & & & & & & & & & & & & & & & & \\
\hline 208 & CR- 02 & 8.2 & 17 & 3.0 & 91.0 & 26.0 & 0.020 & 10 & 0.1 & & 400.0 & 25.0 & 6 & 0.30 & 373 & 365 & 103 & \\
\hline 209 & $D A-01$ & 7.9 & 451 & 7.8 & 194.0 & 61.0 & & & 0.3 & & 144.0 & 112.0 & 1060 & & 2200 & 1957 & 99 & \\
\hline 210 & $\mathrm{DA}-02$ & & & & & & & & & & & & & & 375 & & & \\
\hline 211 & $D A-03$ & 7.8 & 46 & & 27.0 & 6.8 & & 19 & & & 192.0 & 1.2 & 23 & & 222 & 198 & & \\
\hline 212 & $\mathrm{DA}-04$ & 7.8 & 32 & & 25.0 & 7.3 & & 30 & & & 161.0 & 3.2 & 18 & & 195 & 165 & & \\
\hline
\end{tabular}




\begin{tabular}{|c|c|c|c|c|c|c|c|c|c|c|c|c|c|c|c|c|c|c|c|}
\hline ID & MAP NO. & $\mathrm{pH}$ & $\mathrm{Na}$ & $\mathrm{k}$ & $\mathrm{Ca}$ & $M g$ & Fe & $\mathrm{SLO} 2$ & B & $L i$ & $\mathrm{HCO} 3$ & $\mathrm{SO} 4$ & $\mathrm{Cl}$ & F & TDSm & TDSC & $\begin{array}{l}C / A \\
\left(\frac{z}{b}\right)\end{array}$ & $\begin{array}{l}\delta D \\
z .1\end{array}$ & $\begin{array}{l}8018 \\
(8 .)\end{array}$ \\
\hline $\begin{array}{l}213 \\
214\end{array}$ & $\begin{array}{l}D A-05 \\
D A-06\end{array}$ & 7.5 & 57 & 2.0 & 29.0 & 3.8 & & 28 & & & 220.0 & 3.0 & 18 & & 251 & 221 & 202 & & \\
\hline 215 & $D A-06$ & 7.9 & 60 & & 30.0 & 3.4 & & 26 & & & 230.0 & 1.0 & 20 & & 267 & 227 & 100 & & \\
\hline 216 & $D A-07$ & 7.8 & 110 & & 20.0 & 3.9 & & 26 & & & 300.0 & 2.0 & 40 & & 354 & 323 & 100 & & \\
\hline 217 & $D A-07$ & 7.8 & 111 & & 20.0 & 3.9 & & 26 & & & 301.0 & 2.0 & 40 & & 354 & 325 & & & \\
\hline 228 & $D A-08$ & 7.6 & 250 & 2.1 & 26.0 & 4.4 & 0.480 & 32 & & & 79.0 & 22.0 & 370 & 4.40 & 752 & 718 & 103 & & \\
\hline 219 & $D A-09$ & 7.2 & 36 & & 41.0 & 17.0 & & 18 & & & 269.0 & 1.0 & 21 & 0.20 & 272 & 248 & & & \\
\hline 220 & $D A-10$ & 7.8 & 170 & 5.0 & 48.0 & 11.0 & 0.390 & 42 & 0.1 & & 170.0 & 10.0 & 290 & 0.60 & 660 & 619 & 96 & & \\
\hline 221 & $D A-10$ & 8.0 & 360 & & 68.0 & 21.0 & & 30 & & & 170.0 & 24.0 & 630 & & 1210 & 1187 & 98 & & \\
\hline 222 & $D A-10$ & 7.7 & 202 & 4.8 & 51.0 & 21.0 & 0.340 & 35 & 0.2 & & 187.0 & 12.0 & 350 & 0.50 & 783 & 734 & 100 & & \\
\hline 223 & $D A-11$ & 7.6 & 15 & & 75.0 & 21.0 & 0.030 & 11 & & & 296.0 & 38.0 & 17 & 0.20 & 325 & 312 & & & \\
\hline 224 & $D A-12$ & & 2390 & 283.0 & 523.0 & 118.0 & & 28 & & & 245.0 & 36.0 & 5100 & 0.60 & 8600 & 8599 & 99 & & \\
\hline 225 & $D A-12$ & 8.4 & 2463 & 204.0 & 459.0 & 72.0 & & 24 & 0.7 & 1.8 & 235.0 & 30.0 & 4640 & 1.00 & & 7985 & 104 & -140.0 & -15.8 \\
\hline 226 & $D A-12$ & & 2520 & 285.0 & 535.0 & 92.0 & & 35 & & & 234.0 & 36.0 & 4370 & 0.70 & 9310 & 7954 & 118 & & \\
\hline 227 & $D A-13$ & 7.6 & 8290 & 803.0 & 536.0 & 458.0 & & 48 & & & 304.0 & 219.0 & 14400 & & 27800 & 24855 & 107 & & \\
\hline 228 & DU-01 & 7.4 & 23 & 4.4 & 85.0 & 27.0 & 0.020 & 16 & & & 190.0 & 180.0 & 24 & 0.90 & 454 & 438 & 100 & & \\
\hline 229 & $\star D U-02$ & 8.0 & 880 & 13.0 & 30.0 & 55.0 & & 47 & & & 1256.0 & 1000.0 & 86 & 4.40 & 2760 & 2686 & 101 & & \\
\hline 230 & $E M-01$ & 7.2 & & & & & & & & & & & & & & & & & \\
\hline 231 & $* E M-02$ & 6.9 & 550 & 3.0 & 190.0 & 230.0 & 0.020 & 16 & 0.4 & & 305.0 & 2000.0 & 130 & 0.40 & 3270 & 3253 & 104 & & \\
\hline 232 & EM-03 & 8.0 & & & & & & & & & & & & & & & & & \\
\hline 233 & EM-04 & 7.8 & 21 & 3.0 & 85.0 & 56.0 & & 8 & 0.1 & & 420.0 & 160.0 & 10 & 0.20 & 549 & 542 & 93 & & \\
\hline 234 & $E M-05$ & 6.4 & 880 & 25.0 & 430.0 & 260.0 & 0.020 & 10 & 0.4 & & 219.0 & 3300.0 & 230 & 0.80 & 5210 & 5234 & 103 & & \\
\hline 235 & ${ }^{*} E M-06$ & 6.2 & 460 & 6.0 & 190.0 & 320.0 & 0.020 & 23 & 0.3 & & 427.0 & 2000.0 & 120 & 0.30 & 3320 & 3306 & 107 & & \\
\hline 236 & EM-07 & 8.8 & 950 & 5.0 & 10.0 & 6.7 & 0.030 & 7 & 0.5 & & 463.0 & 1300.0 & 200 & 1.00 & 2610 & 2700 & 105 & & \\
\hline 237 & .EM-08 & & 360 & & 908.0 & 288.0 & & & 0,4 & & 2840.0 & 1540.0 & 215 & & 4710 & 4707 & & & \\
\hline 238 & $E M-09$ & 7.9 & 180 & 4.0 & 31.0 & 29.0 & & 15 & 0.2 & & 280.0 & 350.0 & 20 & & 757 & 742 & 88 & & \\
\hline 239 & $E M-10$ & & 200 & 4.0 & 29.0 & 19.0 & & 16 & 0.2 & & 300.0 & 300.0 & 32 & & 748 & 732 & 97 & & \\
\hline 240 & GA-01 & 7.7 & 8 & 2.0 & 28.0 & 4.0 & & 42 & & & 117.0 & 3.1 & 5 & 0.15 & & 108 & 99 & & \\
\hline 241 & GA-02 & 7.7 & 5 & 2.0 & 28.0 & 6.0 & & 42 & & & 110.0 & 6.9 & 7 & 0.16 & & 109 & 101 & & \\
\hline 242 & $\star G A-03$ & 7.2 & 188 & 43.0 & 50.0 & 80.0 & & 180 & & 0.1 & 1530.0 & 4.0 & 192 & 0.31 & & 1310 & 60 & & \\
\hline 243 & GA-04 & 8.4 & 23 & & 5.0 & 1.0 & & 26 & & & 61.0 & 11.0 & 4 & 0.38 & & 74 & 99 & & \\
\hline 244 & $G A-05$ & 8.2 & 35 & & 35.0 & 6.3 & & 50 & 0.1 & & 186.0 & 14.0 & 16 & 0.30 & 218 & 198 & & & \\
\hline 245 & GA- 06 & & & & & & & & & & & & & & & & & & \\
\hline 246 & GA-07 & 7.3 & 37 & & & & 9.140 & & & & & 136.0 & 45 & 0.09 & 448 & 227 & & & \\
\hline 247 & GA-08 & & 62 & 0.8 & 150.0 & 67.0 & & 19 & 0.1 & & 248.0 & 520.0 & 29 & 0.50 & 971 & 951 & 100 & & \\
\hline 248 & GA-09 & 7.1 & 270 & 9.0 & 220.0 & 150.0 & & 13 & 0.3 & 0.1 & 480.0 & 1400.0 & 22 & 0.40 & 2460 & 2307 & 93 & & \\
\hline 249 & $G A-10$ & 8.2 & 21 & 2.6 & 57.0 & 6.8 & 0.090 & 35 & 0.1 & & 206.0 & 14.0 & 30 & 0.50 & 268 & 233 & 97 & & \\
\hline 250 & GA-11 & & & & & & & & & & & & & & & & & & \\
\hline $\begin{array}{l}251 \\
252\end{array}$ & $\begin{array}{l}G A-12 \\
G A-13\end{array}$ & & & & & & & & & & & & & & & & & & \\
\hline 253 & $G A-14$ & 8.4 & 83 & 6.0 & 21.0 & 12.0 & & 15 & 0.1 & 0.1 & 180.0 & 130.0 & 8 & 0.30 & 368 & 349 & 98 & & \\
\hline 254 & $G A-15$ & 8.5 & 55 & 4.6 & 13.0 & 11.0 & 0.200 & 15 & 0.1 & 0.1. & 153.0 & 60.0 & 8 & 0.20 & 250 & 227 & 102 & & \\
\hline $\begin{array}{l}255 \\
256\end{array}$ & $\begin{array}{l}G A-16 \\
G A-17\end{array}$ & & 20 & & & & & & & & & & & & & & & & \\
\hline $\begin{array}{l}256 \\
257\end{array}$ & $\begin{array}{r}G A-17 \\
* G A-18\end{array}$ & & 300 & 13.0 & 190.0 & 260.0 & & 11 & 0.1 & 0.2 & $\begin{array}{l}197.0 \\
405.0\end{array}$ & $\begin{array}{r}38.0 \\
1800.0\end{array}$ & $\begin{array}{l}24 \\
15\end{array}$ & $\begin{array}{l}0.40 \\
0.40\end{array}$ & $\begin{array}{r}268 \\
2790\end{array}$ & $\begin{array}{r}246 \\
2778\end{array}$ & $\begin{array}{r}107 \\
99\end{array}$ & & \\
\hline 258 & GA-19 & & & & & & & & & & & & & & & & & -121.0 & -15.8 \\
\hline 259 & $G A-20$ & & 520 & 11.0 & 360.0 & 130.0 & & 16 & 0.1 & 0.2 & 152.0 & 2200.0 & 45 & 0.60 & 3380 & 3341 & 104 & & \\
\hline $\begin{array}{l}260 \\
261\end{array}$ & $G A-21$ & & & & & & & & & & & & & & & & & & \\
\hline $\begin{array}{l}261 \\
262\end{array}$ & $\begin{array}{l}\text { GR }-01 \\
\text { GR-02 }\end{array}$ & $\begin{array}{l}8.3 \\
7.6\end{array}$ & $\begin{array}{l}530 \\
290\end{array}$ & $\begin{array}{l}4.0 \\
5.0\end{array}$ & 11.0 & $\begin{array}{r}4.0 \\
2.0\end{array}$ & 0.100 & $\begin{array}{l}10 \\
11\end{array}$ & & & 335.0 & 160.0 & 560 & 0.60 & 1470 & 1434 & 97 & & \\
\hline 262 & $\begin{array}{r}\text { GR }-02 \\
* G R-03\end{array}$ & 7.6 & $\begin{array}{r}290 \\
35\end{array}$ & 5.0 & 48.0 & 18.0 & 2.100 & 11 & & & 445.0 & 400.0 & 30 & 0.80 & 1020 & 1013 & 101 & & \\
\hline 263 & $\star G R-03$ & 7.8 & 35 & 6.0 & 28.0 & 29.0 & & 99 & & & 210.0 & 41.0 & 38 & 0.30 & 280 & 281 & 101 & & \\
\hline 264 & GR-04 & 7.8 & 19 & 3.0 & 77.0 & 19.0 & & 13 & & & 210.0 & 110.0 & 18 & 0.30 & 362 & 350 & 101 & & \\
\hline 265 & GR-04 & 7.8 & 21 & 2.0 & 72.0 & 18.0 & & 11 & & & 232.0 & 95.0 & 12 & 0.30 & 344 & 334 & 98 & & \\
\hline
\end{tabular}




\begin{tabular}{|c|c|c|c|c|c|c|c|c|c|c|c|c|c|c|c|c|c|c|c|}
\hline ID & MAP NO. & $\mathrm{pH}$ & $\mathrm{Na}$ & $\mathrm{k}$ & $\mathrm{Ca}$ & Mg & $\mathrm{Fe}$ & $\mathrm{SiO} 2$ & B & $L i$ & $\mathrm{HCO} 3$ & SO4 & Cl & $F$ & TDSm & TDSC & $\underset{(z)}{C / A}$ ( & $\begin{array}{r}\delta D \\
(\xi .)\end{array}$ & $\begin{array}{l}\delta 018 \\
(8 .)\end{array}$ \\
\hline $\begin{array}{l}266 \\
267 \\
268\end{array}$ & $\begin{array}{l}\text { GR-04 } \\
\text { GR-05 } \\
\text { GR-05 }\end{array}$ & $\begin{array}{l}7.5 \\
7.6 \\
7.6\end{array}$ & 21 & 3.0 & 82.0 & 22.0 & & 12 & & & 220.0 & 130.0 & 20 & 0.10 & 400 & 386 & 100 & & \\
\hline $\begin{array}{l}269 \\
270\end{array}$ & $\begin{array}{l}\text { IR-01 } \\
\text { IR-02 }\end{array}$ & $\begin{array}{l}8.1 \\
7.7\end{array}$ & $\begin{array}{l}20 \\
28\end{array}$ & $\begin{array}{l}5.0 \\
5.0\end{array}$ & $\begin{array}{l}78.0 \\
35.0\end{array}$ & $\begin{array}{r}21.0 \\
6.0\end{array}$ & & $\begin{array}{l}36 \\
58\end{array}$ & & & $\begin{array}{l}346.0 \\
170.0\end{array}$ & $\begin{array}{r}16.0 \\
0.8\end{array}$ & $\begin{array}{l}29 \\
28\end{array}$ & $\begin{array}{l}0.28 \\
0.32\end{array}$ & & $\begin{array}{l}339 \\
187\end{array}$ & $\begin{array}{l}97 \\
99\end{array}$ & & \\
\hline $\begin{array}{l}271 \\
272\end{array}$ & $\begin{array}{l}\text { IR-03 } \\
\text { IR-04 }\end{array}$ & $\begin{array}{l}8.2 \\
8.1\end{array}$ & $\begin{array}{l}21 \\
40\end{array}$ & $\begin{array}{l}2.6 \\
5.0\end{array}$ & $\begin{array}{l}57.0 \\
25.0\end{array}$ & $\begin{array}{l}6.8 \\
6.0\end{array}$ & 0.090 & $\begin{array}{l}35 \\
52\end{array}$ & 0.1 & & $\begin{array}{l}206.0 \\
155.0\end{array}$ & $\begin{array}{r}14.0 \\
8.9\end{array}$ & $\begin{array}{l}30 \\
11\end{array}$ & $\begin{array}{l}0.50 \\
0.34\end{array}$ & 268 & $\begin{array}{l}233 \\
172\end{array}$ & $\begin{array}{r}97 \\
118\end{array}$ & & \\
\hline 273 & IR -05 & 7.9 & 78 & 7.0 & 85.0 & 29.0 & & 58 & & 0.1 & 153.0 & 180.0 & 110 & 2.60 & & 567 & 108 & & \\
\hline $\begin{array}{l}274 \\
275\end{array}$ & $\begin{array}{l}\text { IR-06 } \\
\text { IR-07 }\end{array}$ & $\begin{array}{l}7.1 \\
7.1\end{array}$ & $\begin{array}{l}51 \\
60\end{array}$ & & $\begin{array}{r}95.0 \\
123.0\end{array}$ & $\begin{array}{l}27.0 \\
27.0\end{array}$ & & $\begin{array}{l}42 \\
33\end{array}$ & & & $\begin{array}{l}367.0 \\
334.0\end{array}$ & $\begin{array}{l}24.0 \\
54.0\end{array}$ & $\begin{array}{r}60 \\
765\end{array}$ & 0.50 & 482 & 428 & 101 & & \\
\hline $\begin{array}{l}275 \\
276\end{array}$ & IR -08 & 8.0 & 15 & 5.3 & 31.0 & 6.8 & & 58 & & & $\begin{array}{l}334.0 \\
130.0\end{array}$ & $\begin{array}{l}54.0 \\
11.0\end{array}$ & $\begin{array}{r}165 \\
15\end{array}$ & $\begin{array}{l}0.50 \\
0.20\end{array}$ & $\begin{array}{l}724 \\
210\end{array}$ & $\begin{array}{l}594 \\
148\end{array}$ & $\begin{array}{r}97 \\
104\end{array}$ & & \\
\hline 277 & IR-09 & 7.1 & 376 & 24.0 & 145.0 & 14.0 & 1.640 & 44 & 0.9 & 1.0 & 476.0 & 359.0 & 366 & 4.00 & 1556 & 1524 & $\begin{array}{r}104 \\
99\end{array}$ & & \\
\hline 278 & IR-10 & 7.2 & 405 & 34.0 & 140.0 & 18.0 & 0.030 & 49 & 1.1 & 1.1 & 376.0 & 367.0 & 447 & 3.10 & 1760 & 1599 & 102 & & \\
\hline $\begin{array}{l}279 \\
280\end{array}$ & $\begin{array}{l}\text { IR }-10 \\
\text { IR-11 }\end{array}$ & $\begin{array}{l}7.4 \\
7.1\end{array}$ & $\begin{array}{l}445 \\
395\end{array}$ & $\begin{array}{l}40.9 \\
34.0\end{array}$ & $\begin{array}{l}146.0 \\
145.0\end{array}$ & $\begin{array}{l}16.5 \\
14.0\end{array}$ & $\begin{array}{l}0.030 \\
0.050\end{array}$ & $\begin{array}{l}65 \\
52\end{array}$ & $\begin{array}{l}1.0 \\
1.0\end{array}$ & $\begin{array}{l}1.2 \\
1.1\end{array}$ & $\begin{array}{l}452.0 \\
351.0\end{array}$ & 400.0 & 468 & 3.34 & $\begin{array}{l}1796 \\
1730\end{array}$ & $\begin{array}{l}1742 \\
1543\end{array}$ & 100 & & \\
\hline $\begin{array}{l}280 \\
281\end{array}$ & IR-12 & 7.6 & 54 & 8.0 & 96.0 & 34.0 & 0.050 & 46 & $\begin{array}{l}1.0 \\
0.3\end{array}$ & 1.1 & $\begin{array}{l}351.0 \\
167.0\end{array}$ & $\begin{array}{l}376.0 \\
188.0\end{array}$ & $\begin{array}{r}402 \\
46\end{array}$ & $\begin{array}{l}3.90 \\
0.70\end{array}$ & $\begin{array}{r}2730 \\
672\end{array}$ & $\begin{array}{r}1543 \\
509\end{array}$ & $\begin{array}{l}106 \\
127\end{array}$ & & \\
\hline 282 & IR-13 & 7.9 & 25 & 7.0 & 41.0 & 12.0 & 0.100 & 58 & & & 292.0 & 26.0 & 37 & 0.50 & 304 & 291 & 66 & & \\
\hline 283 & IR- 14 & 7.5 & $\begin{array}{l}28 \\
50\end{array}$ & 5.0 & 45.0 & 28.0 & & 36 & 0.1 & & 220.0 & 64.0 & 24 & 0.40 & 342 & 303 & 104 & & \\
\hline $\begin{array}{l}284 \\
285\end{array}$ & $\begin{array}{l}I R-15 \\
\text { IR-16 }\end{array}$ & 7.9 & 50 & 4.3 & 80.0 & 52.0 & 0.040 & 26 & 0.1 & & 139.0 & 330.0 & 40 & 0.20 & $\begin{array}{r}653 \\
4000\end{array}$ & 625 & 102 & & \\
\hline $\begin{array}{l}286 \\
287\end{array}$ & $\begin{array}{r}\text { *IR }-17 \\
\text { IR }-18\end{array}$ & $\begin{array}{l}9.1 \\
7.7\end{array}$ & $\begin{array}{r}148 \\
37\end{array}$ & $\begin{array}{r}3.0 \\
10.0\end{array}$ & $\begin{array}{r}5.0 \\
57.0\end{array}$ & 9.0 & $\begin{array}{l}0.060 \\
0.010\end{array}$ & $\begin{array}{l}54 \\
72\end{array}$ & $\begin{array}{l}5.3 \\
0.2\end{array}$ & 0.2 & $\begin{array}{l}259.0 \\
194.0\end{array}$ & $\begin{array}{r}40.0 \\
80.0\end{array}$ & $\begin{array}{l}26 \\
25\end{array}$ & $\begin{array}{r}34.00 \\
0.50\end{array}$ & $\begin{array}{l}446 \\
389\end{array}$ & $\begin{array}{l}383 \\
314\end{array}$ & $\begin{array}{r}116 \\
98\end{array}$ & & \\
\hline $\begin{array}{l}288 \\
289\end{array}$ & $\begin{array}{l}\text { IR-19 } \\
\text { IR-20 }\end{array}$ & 7.4 & 120 & 4.0 & 40.0 & 6.9 & 0.010 & 53 & 0.3 & & 204.0 & 150.0 & 44 & 1.70 & 520 & 467 & 202 & & \\
\hline 290 & IR-2I & 7.8 & 240 & 9.0 & 80.0 & 15.0 & & 54 & 0.6 & & 112.0 & 570.0 & 63 & 4.90 & 1080 & 1037 & 102 & & \\
\hline $\begin{array}{l}292 \\
293\end{array}$ & $\begin{array}{l}\text { IR-22 } \\
\text { IR-23 }\end{array}$ & $\begin{array}{l}7.7 \\
7.9\end{array}$ & $\begin{array}{l}267 \\
250\end{array}$ & 11.7 & $\begin{array}{l}53.0 \\
64.4\end{array}$ & $\begin{array}{l}3.4 \\
5.5\end{array}$ & & $\begin{array}{l}76 \\
63\end{array}$ & 0.6 & 0.3 & $\begin{array}{r}91.0 \\
104.0\end{array}$ & $\begin{array}{l}492.0 \\
478.0\end{array}$ & $\begin{array}{l}93 \\
76\end{array}$ & 4.70 & $\begin{array}{l}1040 \\
1016\end{array}$ & $\begin{array}{l}681 \\
941\end{array}$ & $\begin{array}{r}24 \\
107\end{array}$ & & \\
\hline $\begin{array}{l}293 \\
294\end{array}$ & IR -23 & 7.3 & 270 & 15.0 & 60.0 & 5.8 & 0.300 & 52 & 1.0 & 0.5 & 20.00 & 200.0 & 190 & 4.60 & & 746 & 163 & -224.0 & -13.4 \\
\hline $\begin{array}{l}295 \\
296\end{array}$ & $\begin{array}{l}\text { IR-24 } \\
\text { IR-25 }\end{array}$ & 8.0 & 273 & 15.2 & 64.6 & 0.8 & & 79 & 0.3 & 0.5 & 58.0 & 569.0 & 69 & 7.30 & 1154 & 1028 & 105 & -107.0 & -14.2 \\
\hline $\begin{array}{l}297 \\
298\end{array}$ & $\begin{array}{l}\text { IR-26 } \\
\text { IR-27 }\end{array}$ & $\begin{array}{l}8.0 \\
7.6\end{array}$ & $\begin{array}{l}290 \\
270\end{array}$ & $\begin{array}{l}17.0 \\
21.0\end{array}$ & $\begin{array}{l}78.7 \\
58.0\end{array}$ & $\begin{array}{l}0.7 \\
0.4\end{array}$ & 0.010 & $\begin{array}{l}69 \\
99\end{array}$ & 0.7 & $\begin{array}{l}0.6 \\
0.5\end{array}$ & $\begin{array}{l}44.0 \\
64.0\end{array}$ & $\begin{array}{l}637.0 \\
580.0\end{array}$ & $\begin{array}{r}104 \\
52\end{array}$ & $\begin{array}{l}6.30 \\
7.30\end{array}$ & $\begin{array}{l}1236 \\
1120\end{array}$ & $\begin{array}{l}1156 \\
1020\end{array}$ & $\begin{array}{l}100 \\
104\end{array}$ & -108.0 & -24.3 \\
\hline $\begin{array}{l}299 \\
300\end{array}$ & $\begin{array}{l}I R-27 \\
I R-28\end{array}$ & $\begin{array}{l}8.4 \\
7.8\end{array}$ & $\begin{array}{r}240 \\
31\end{array}$ & $\begin{array}{r}14.0 \\
4.1\end{array}$ & $\begin{array}{l}36.0 \\
47.0\end{array}$ & $\begin{array}{r}0.6 \\
30.0\end{array}$ & $\begin{array}{l}0.200 \\
0.020\end{array}$ & $\begin{array}{r}140 \\
51\end{array}$ & $\begin{array}{l}0.8 \\
0.1\end{array}$ & 0.4 & 180.0 & $\begin{array}{l}250.0 \\
140.0\end{array}$ & $\begin{array}{l}45 \\
12\end{array}$ & $\begin{array}{l}4.00 \\
0.30\end{array}$ & 408 & $\begin{array}{l}590 \\
353\end{array}$ & $\begin{array}{l}195 \\
101\end{array}$ & -121.0 & -13.8 \\
\hline $\begin{array}{l}301 \\
302\end{array}$ & $\begin{array}{l}\text { IR }-29 \\
\text { IR-30 }\end{array}$ & 7.7 & 34 & & 47.0 & 28.0 & 0.020 & 54 & & & 178.0 & 137.0 & 12 & & 403 & 346 & & & \\
\hline 303 & IR-3I & 7.8 & 27 & 2.0 & 40.0 & 7.8 & 0.010 & $\begin{array}{l}43 \\
20\end{array}$ & 0.1 & & 158.0 & 13.0 & 36 & 0.20 & 251 & $\begin{array}{r}204 \\
2791\end{array}$ & 99 & & \\
\hline $\begin{array}{l}304 \\
305\end{array}$ & $\begin{array}{l}J U-01 \\
J U-02\end{array}$ & $\begin{array}{l}7.3 \\
7.4\end{array}$ & $\begin{array}{r}800 \\
6400\end{array}$ & $\begin{array}{r}53.0 \\
170.0\end{array}$ & $\begin{array}{l}120.0 \\
650.0\end{array}$ & & $\begin{array}{l}0.020 \\
0.230\end{array}$ & $\begin{array}{l}20 \\
25\end{array}$ & $\begin{array}{l}0.9 \\
2.8\end{array}$ & & $\begin{array}{l}300.0 \\
202.0\end{array}$ & $\begin{array}{r}400.0 \\
1400.0\end{array}$ & $\begin{array}{r}1200 \\
\end{array}$ & 1.10 & 21000 & $\begin{array}{r}2791 \\
20991\end{array}$ & $\begin{array}{r}101 \\
90\end{array}$ & & \\
\hline 306 & $\mathrm{JU}-03$ & 7.7 & 470 & 36.0 & 136.0 & & & 20 & 0.8 & & 312.0 & 340.0 & $\begin{array}{r}12000 \\
630\end{array}$ & $\begin{array}{l}1.60 \\
2.00\end{array}$ & $\begin{array}{r}21000 \\
1820\end{array}$ & $\begin{array}{r}20991 \\
1814\end{array}$ & $\begin{array}{r}90 \\
101\end{array}$ & & \\
\hline 307 & JU- 03 & 7.8 & 510 & 45.0 & 115.0 & 60.0 & & 22 & 1.2 & & 270.0 & & 960 & 0.50 & & 1823 & & -129.0 & -13.8 \\
\hline 308 & JU-04 & 8.0 & 470 & 43.0 & 95.0 & 55.0 & & 19 & & & 313.0 & 380.0 & 640 & 1.40 & 1860 & 1838 & 99 & & \\
\hline 309 & JU-05 & 7.3 & 480 & 45.0 & 100.0 & 54.0 & 0.020 & 19 & 0.9 & & 310.0 & 390.0 & 670 & 1.20 & & 1893 & 98 & -111.0 & -13.6 \\
\hline $\begin{array}{l}310 \\
311\end{array}$ & $\begin{array}{l}\text { JU-06 } \\
\text { JU-06 }\end{array}$ & $\begin{array}{l}7.3 \\
7.5\end{array}$ & $\begin{array}{l}490 \\
460\end{array}$ & $\begin{array}{l}42.0 \\
39.0\end{array}$ & $\begin{array}{r}100.0 \\
95.0\end{array}$ & $\begin{array}{l}58.0 \\
53.0\end{array}$ & & 22 & $\begin{array}{l}0.6 \\
0.9\end{array}$ & & $\begin{array}{l}310.0 \\
294.0\end{array}$ & $\begin{array}{l}390.0 \\
340.0\end{array}$ & $\begin{array}{l}650 \\
600\end{array}$ & 1.20 & 1900 & $\begin{array}{l}1884 \\
1732\end{array}$ & 101 & & \\
\hline 312 & JU-07 & & & & & & & & & & & -20.0 & & & & 1732 & 104 & & \\
\hline 313 & JU-08 & & & & & & & & & & & & & & & & & & \\
\hline 314 & JU-09 & 7.2 & 232 & & 69.0 & 27.0 & & 38 & & & 222.0 & 81.0 & 368 & & 962 & 886 & & & \\
\hline 315 & $J U-10$ & 6.9 & 19 & & 46.0 & 8.1 & 0.020 & 34 & & & 185.0 & 23.0 & 12 & 0.20 & 234 & 199 & 98 & & \\
\hline 316 & JU-11 & 7.3 & 870 & 18.0 & 690.0 & 170.0 & 0.120 & 31 & 0.5 & & 230.0 & 380.0 & 2500 & 2.90 & 4780 & 4744 & 105 & & \\
\hline 317 & JU-12 & 7.6 & 1600 & 110.0 & 280.0 & 120.0 & 0.050 & 22 & 1.5 & & 449.0 & 410.0 & 2700 & 0.80 & 5400 & 5432 & 103 & & \\
\hline
\end{tabular}




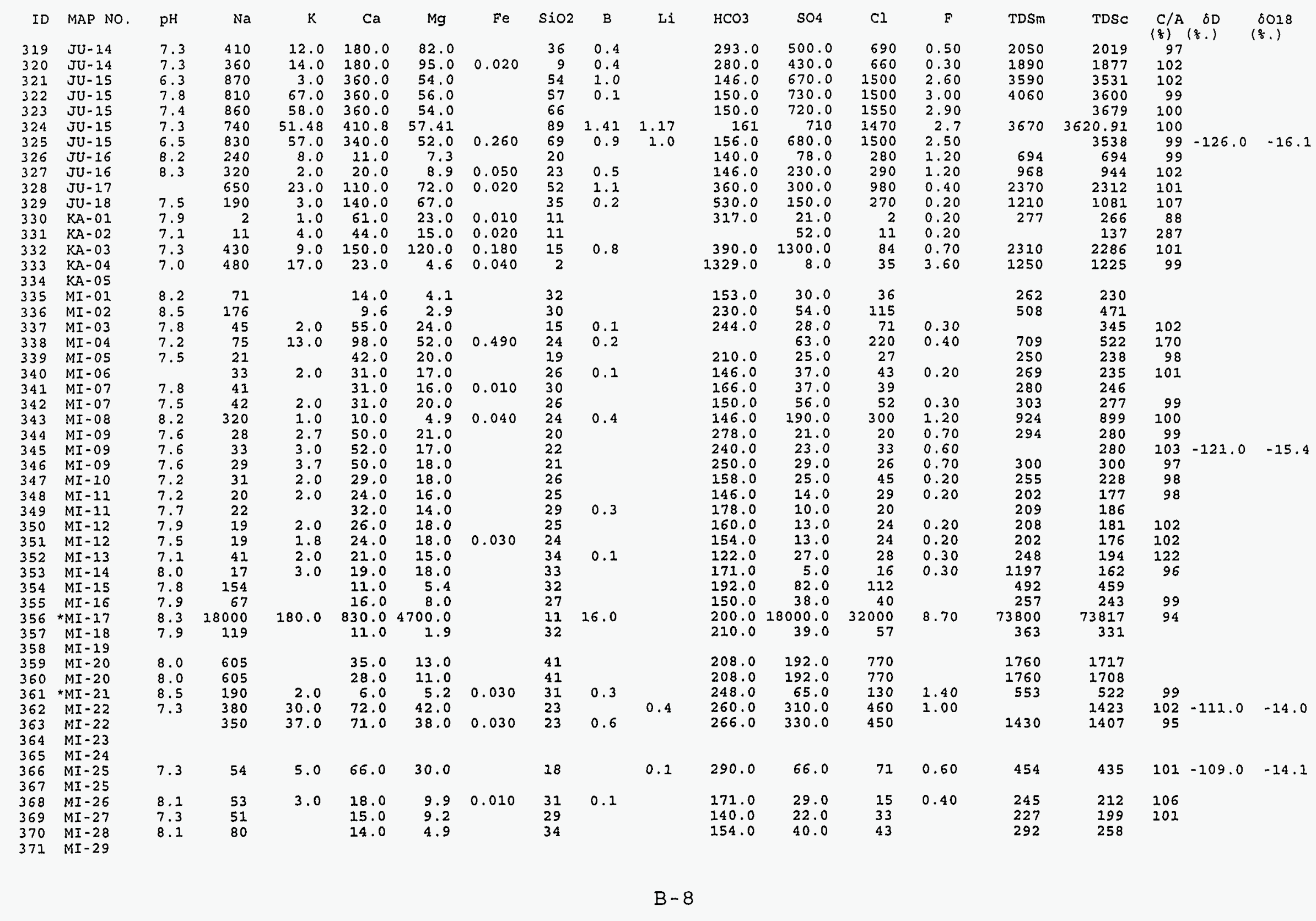




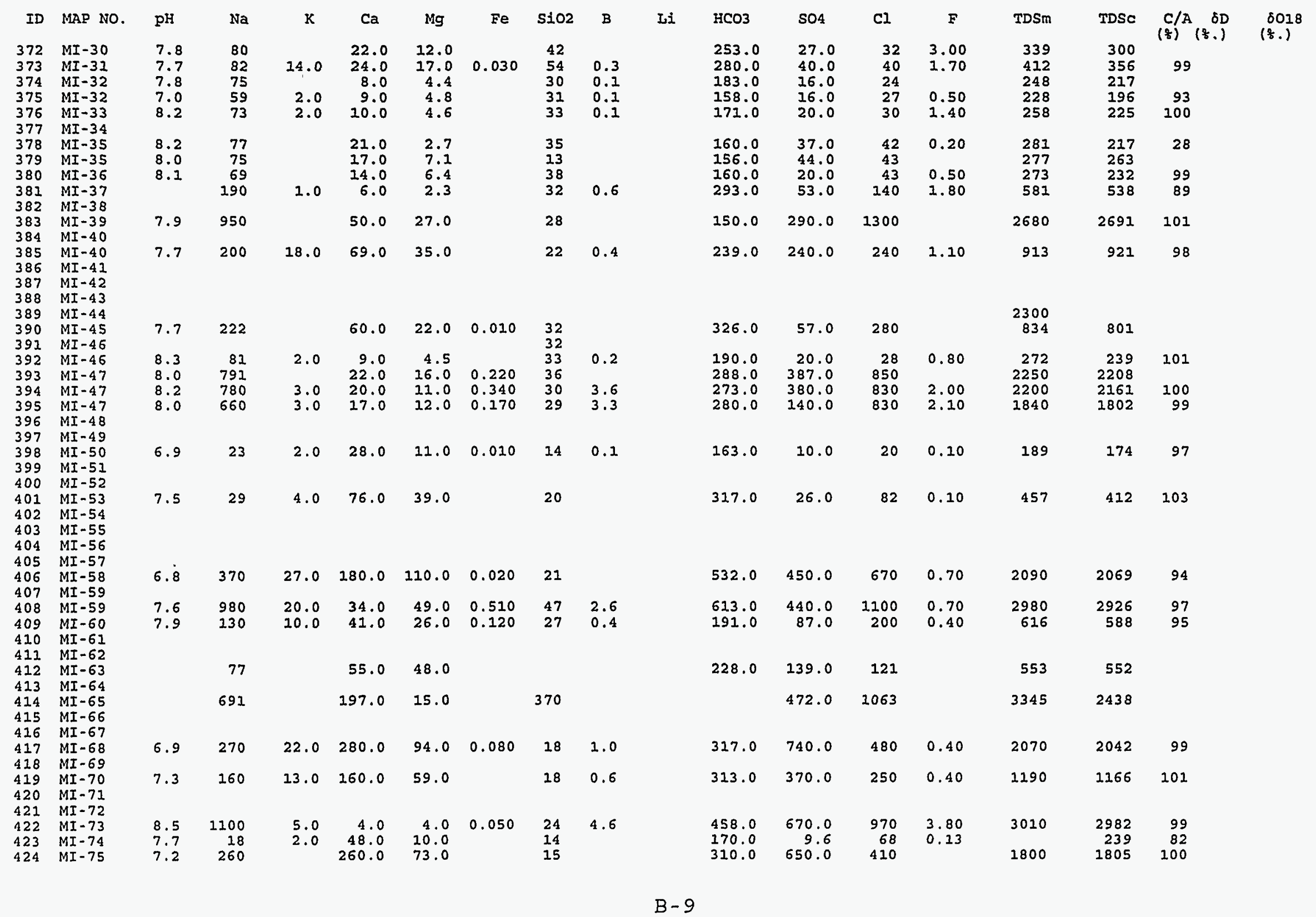




\begin{tabular}{|c|c|c|c|c|c|c|c|}
\hline ID & MAP NO. & $\mathrm{pH}$ & $\mathrm{Na}$ & $\mathrm{k}$ & $\mathrm{Ca}$ & $\mathrm{Mg}$ & $\mathrm{Fe}$ \\
\hline 425 & $M I-76$ & 7.3 & 5 & & 53.0 & 9.0 & \\
\hline 426 & $\begin{array}{l}M I-77 \\
M I-78\end{array}$ & & & & 464.0 & 95.0 & \\
\hline 427 & MI - 78 & 7.0 & 1176 & 168.0 & 483.0 & 107.0 & 0.600 \\
\hline 428 & MI - 79 & & & & & & \\
\hline 429 & $M I-80$ & 7.6 & 1000 & 16.0 & 420.0 & 97.0 & \\
\hline 430 & $M I-80$ & 6.7 & 1058 & 148.2 & 468.4 & 92.9 & 0.050 \\
\hline 431 & $M I-8 I$ & 7.7 & 1100 & 16.0 & 450.0 & 100.0 & \\
\hline 432 & $M I-81$ & 6.9 & 1000 & 130.0 & 480.0 & 94.0 & 0.040 \\
\hline 433 & $M I-81$ & 7.5 & 1000 & 24.0 & 430.0 & 110.0 & \\
\hline 434 & $M I-81$ & 7.5 & 1020 & 13.8 & 433.0 & 114.0 & \\
\hline 435 & $M I=81$ & 6.6 & 980 & 140.0 & 525.0 & 95.0 & \\
\hline 436 & $M I-82$ & 6.8 & 1054 & 149.1 & 467.8 & 92.3 & \\
\hline 437 & $M I-83$ & & & & & & \\
\hline 438 & $M I=84$ & 6.7 & & & 465.0 & 89.0 & \\
\hline 439 & $M I-84$ & 6.7 & 890 & 160.0 & 420.0 & 89.0 & 0.520 \\
\hline 440 & $M I-84$ & 7.1 & 1041 & 137.0 & 438.0 & 86.0 & 0.300 \\
\hline 441 & $M I-85$ & 7.3 & 410 & 66.0 & 180.0 & 46.0 & \\
\hline 442 & $M I-86$ & 7.6 & 1280 & 130.0 & 230.0 & 130.0 & \\
\hline 443 & $M I-87$ & 8.8 & 2210 & 19.0 & 185.0 & 50.0 & \\
\hline 444 & $M I-87$ & 8.0 & 1400 & 14.0 & 150.0 & 49.0 & 0.070 \\
\hline 445 & $M I-87$ & 7.4 & 1292 & 13.0 & 150.0 & 49.0 & \\
\hline 446 & MI - 87 & 7.6 & 1200 & 14.0 & 135.0 & 48.0 & 0.300 \\
\hline 447 & $M I=88$ & 7.8 & 130 & 3.0 & 53.0 & 17.0 & \\
\hline 448 & MI-89 & 7.8 & 96 & 5.8 & 66.0 & 21.0 & 0.070 \\
\hline 449 & $M I-90$ & 7.7 & 220 & 8.0 & 75.0 & 17.0 & \\
\hline 450 & $M I-9 I$ & 7.6 & 220 & 8.0 & 90.0 & 21.0 & \\
\hline 451 & $M I-92$ & 8.3 & 38 & 6.0 & & 20.0 & \\
\hline 452 & $M I-93$ & 8.7 & 30 & 2.0 & 60.0 & 14.0 & \\
\hline 453 & $M I-94$ & 6.8 & 75 & 3.6 & 53.0 & 16.0 & 0.370 \\
\hline 454 & $M I-95$ & 7.9 & 86 & 9.0 & 38.0 & 24.0 & \\
\hline 455 & *MI - 96 & 7.4 & 1220 & 41.5 & 332.0 & 115.2 & \\
\hline 456 & $M I-97$ & 7.4 & 355 & 56.2 & 74.4 & 19.2 & \\
\hline 457 & $M I-98$ & 7. & 59 & 6.0 & & & \\
\hline 458 & MI - 99 & 7.8 & 23 & 6.0 & 63.0 & 10.0 & \\
\hline 459 & $M I-100$ & 6.3 & 20 & 6.0 & 62.0 & 12.0 & 0.540 \\
\hline 460 & MO-01 & 7.4 & 34 & 8.4 & 109.0 & 31.0 & \\
\hline 461 & $P I-01$ & 7.7 & 8 & 2.0 & 85.0 & 9.0 & \\
\hline 462 & $\mathrm{PI}-02$ & 8.2 & 28 & & 25.0 & 3.0 & \\
\hline 463 & $P I=03$ & 7.7 & & & & & \\
\hline 464 & $\mathrm{PI}-04$ & 8.0 & 22 & 5.0 & 53.0 & 15.0 & \\
\hline 465 & $S A-01$ & 8.0 & 69 & 6.0 & & 13.0 & 0.060 \\
\hline 466 & $\mathrm{SA}-02$ & 7.6 & 26 & 12.0 & 42.0 & 11.0 & \\
\hline 467 & SA-03 & 10.2 & 3600 & 77.0 & 1.0 & 0.1 & \\
\hline 468 & $S A-04$ & & 129 & & 26.0 & 15.0 & \\
\hline 469 & *SA-05 & 8.3 & 200 & 10.0 & 39.0 & 64.0 & \\
\hline 470 & $S A-06$ & 8.3 & 94 & 3.8 & 38.0 & 19.0 & \\
\hline 471 & SA-06 & 8.1 & 81 & 1.7 & 37.0 & 23.0 & 0.020 \\
\hline 472 & * SA -07 & 8.5 & 14 & 1.0 & 48.0 & 53.0 & \\
\hline 473 & SE-01 & 8.0 & 144 & 6.5 & 34.0 & 19.0 & 0.030 \\
\hline 474 & $S E-02$ & 7.9 & 12 & 4.0 & 45.0 & 38.0 & \\
\hline 475 & SE-02 & 8.3 & 15 & 3.2 & 51.0 & 35.0 & \\
\hline 476 & SE-03 & 7.8 & 440 & 22.0 & 490.0 & 210.0 & \\
\hline 477 & $S E-04$ & 6.2 & 530 & 55.0 & 300.0 & 36.0 & 0.900 \\
\hline
\end{tabular}

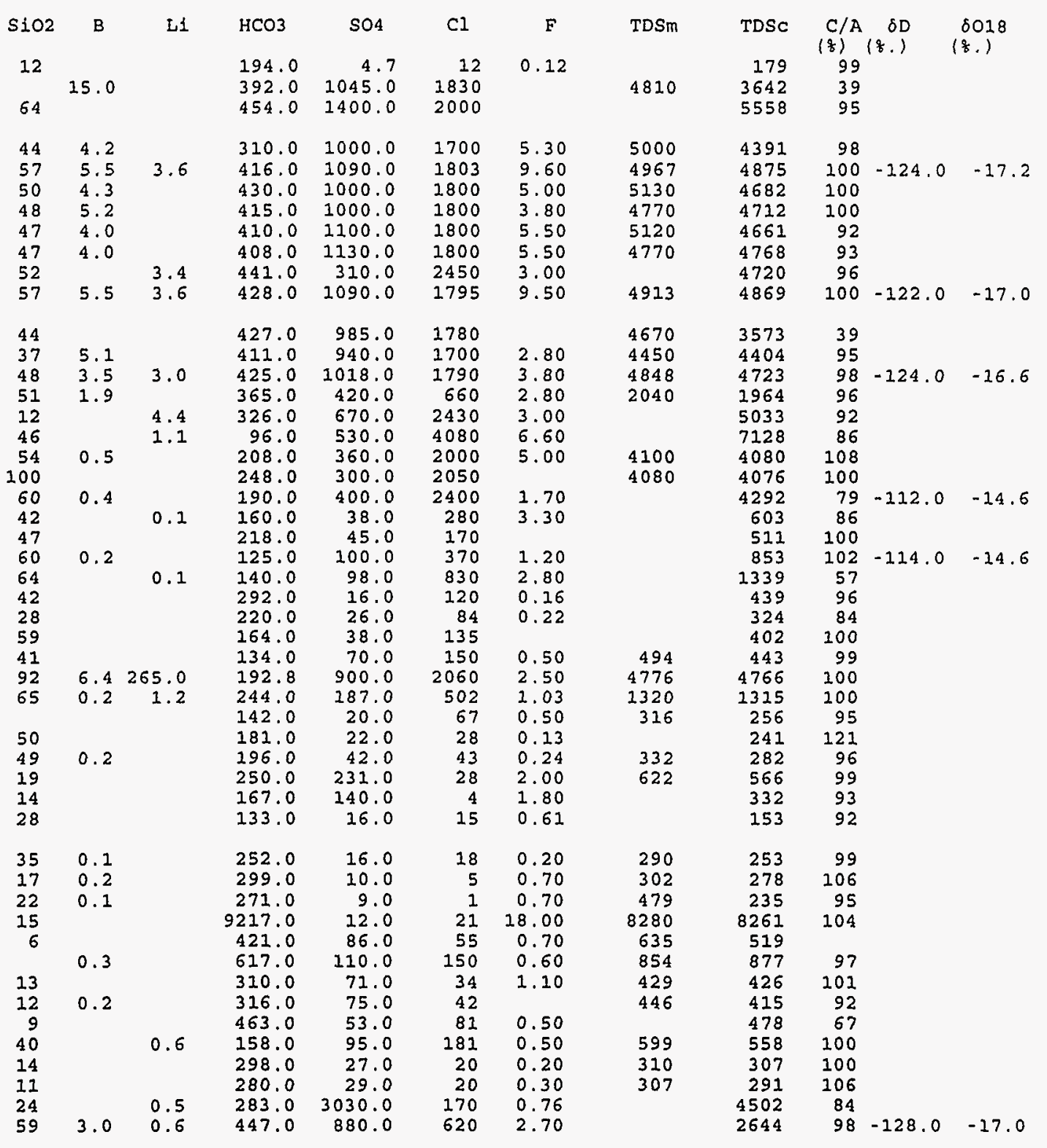




\begin{tabular}{|c|c|c|c|c|c|c|c|c|c|c|c|c|c|c|c|c|c|c|c|}
\hline ID & MAP NO. & $\mathrm{pH}$ & $\mathrm{Na}$ & $\mathrm{K}$ & $\mathrm{Ca}$ & Mg & Fe & SiO2 & B & Li & $\mathrm{HCO} 3$ & SO4 & Cl & $F$ & TDSm & TDSC & $\begin{array}{c}C / A \\
(\xi)\end{array}$ & $\begin{array}{c}\delta D \\
(\xi .)\end{array}$ & $\begin{array}{l}\delta 018 \\
\left(\frac{q}{z} .\right)\end{array}$ \\
\hline $\begin{array}{l}478 \\
479 \\
480 \\
481\end{array}$ & $\begin{array}{l}S E-05 \\
S E-05 \\
S E-06 \\
S E-07\end{array}$ & $\begin{array}{l}6.3 \\
7.3 \\
7.4\end{array}$ & $\begin{array}{r}590 \\
740 \\
44\end{array}$ & $\begin{array}{r}60.0 \\
9.9 \\
1.5\end{array}$ & $\begin{array}{r}290.0 \\
303.0 \\
70.0\end{array}$ & $\begin{array}{l}34.0 \\
30.0 \\
15.0\end{array}$ & 0.014 & $\begin{array}{l}58 \\
48 \\
32\end{array}$ & 0.1 & $\begin{array}{l}0.7 \\
0.8\end{array}$ & $\begin{array}{l}416.0 \\
301.0 \\
175.0\end{array}$ & $\begin{array}{l}890.0 \\
780.0 \\
163.0\end{array}$ & $\begin{array}{r}660 \\
810 \\
14\end{array}$ & $\begin{array}{l}2.80 \\
2.10 \\
1.80\end{array}$ & 428 & $\begin{array}{r}2732 \\
2823 \\
395\end{array}$ & $\begin{array}{l}101 \\
113 \\
100\end{array}$ & -127.0 & -17.0 \\
\hline 482 & $S E-08$ & 6.5 & 1450 & 50.0 & 260.0 & 44.0 & 0.270 & 90 & 4.9 & 1.9 & 408.0 & 1200.0 & 2700 & 3.00 & & 4908 & 101 & -133.0 & -17.3 \\
\hline 483 & SE-09 & 7.5 & & 1.0 & 35.0 & 8.5 & 0.060 & 9 & & & 117.0 & 20.0 & 15 & 0.20 & & 150 & 110 & & \\
\hline $\begin{array}{l}484 \\
485\end{array}$ & $\begin{array}{l}S E-10 \\
S J-01\end{array}$ & $\begin{array}{l}7.5 \\
7.5\end{array}$ & $\begin{array}{r}26 \\
342\end{array}$ & 4.0 & $\begin{array}{l}100.0 \\
150.0\end{array}$ & $\begin{array}{l}41.0 \\
97.0\end{array}$ & & $\begin{array}{l}11 \\
11\end{array}$ & 0.1 & & $\begin{array}{l}430.0 \\
259.0\end{array}$ & $\begin{array}{r}24.0 \\
770.0\end{array}$ & $\begin{array}{r}72 \\
356\end{array}$ & 0.30 & $\begin{array}{r}489 \\
7860\end{array}$ & $\begin{array}{r}479 \\
887\end{array}$ & 100 & & \\
\hline 486 & $S J-02$ & 8.1 & 290 & 5.0 & 7.0 & 3.0 & 2.300 & 12 & & 0.4 & 610.0 & 63.0 & 84 & 1.20 & 766 & $\begin{array}{r}1022 \\
755\end{array}$ & 98 & & \\
\hline 487 & $S J=03$ & 8.1 & 24 & 3.0 & 42.0 & 18.0 & 0.480 & 12 & & & 256.0 & 35.0 & 1 & 0.30 & 260 & 250 & 95 & & \\
\hline $\begin{array}{l}488 \\
489\end{array}$ & $\begin{array}{l}S J-04 \\
S J-05\end{array}$ & $\begin{array}{l}7.9 \\
8.0\end{array}$ & 34 & $\begin{array}{l}3.0 \\
3.0\end{array}$ & $\begin{array}{l}44.0 \\
30.0\end{array}$ & $\begin{array}{l}18.0 \\
13.0\end{array}$ & $\begin{array}{l}0.320 \\
0.310\end{array}$ & $\begin{array}{l}12 \\
16\end{array}$ & & & $\begin{array}{l}232.0 \\
219.0\end{array}$ & $\begin{array}{l}26.0 \\
29.0\end{array}$ & $\frac{1}{2}$ & $\begin{array}{l}0.20 \\
0.20\end{array}$ & $\begin{array}{l}227 \\
235\end{array}$ & 207 & 86 & & \\
\hline $\begin{array}{l}489 \\
490\end{array}$ & $\begin{array}{l}S J-05 \\
S J-06\end{array}$ & 8.4 & 5 & 2.0 & 16.0 & & 0.010 & 10 & & & $\begin{array}{r}219.0 \\
91.0\end{array}$ & $\begin{array}{r}4.0 \\
4.0\end{array}$ & $\begin{array}{l}2 \\
2\end{array}$ & & $\begin{array}{r}235 \\
86\end{array}$ & $\begin{array}{r}219 \\
74\end{array}$ & $\begin{array}{l}97 \\
65\end{array}$ & & \\
\hline 491 & SU-07 & 8.4 & $\begin{array}{l}386 \\
556\end{array}$ & & 13.0 & 7.5 & & 10 & & & 644.0 & 299.0 & 28 & & 1070 & 1050 & & & \\
\hline $\begin{array}{l}492 \\
493\end{array}$ & $\begin{array}{r}\text { *SJ-08 } \\
S J-09\end{array}$ & 9.1 & 556 & & 25.0 & 41.0 & & 15 & & & 822.0 & 673.0 & 44 & 1.10 & 1760 & 1744 & & & \\
\hline 494 & $S J-10$ & 8.8 & 190 & 1.0 & 2.0 & 0.5 & 0.010 & 11 & 0.1 & & 421.0 & 55.0 & 15 & 0.50 & 482 & 471 & 99 & & \\
\hline 495 & SJ-10 & 8.0 & 148 & & 3.2 & 1.5 & & 11 & & & 326.0 & 53.0 & 10 & & 387 & 376 & & & \\
\hline $\begin{array}{l}496 \\
497\end{array}$ & $\begin{array}{l}S J-11 \\
S J-12\end{array}$ & $\begin{array}{l}7.7 \\
7.5\end{array}$ & 660 & 13.0 & 20.0 & 10.0 & 4.400 & 11 & 1.5 & 1.0 & 930.0 & 170.0 & 470 & 1.30 & 1820 & 1806 & 96 & -111.0 & -14.8 \\
\hline 498 & $S J-13$ & 7.5 & 950 & 19.0 & 32.0 & 12.0 & & 11 & & & 975.0 & 290.0 & 750 & 1.40 & 2550 & 2534 & 102 & & \\
\hline 499 & SU-14 & 8.7 & 840 & 25.0 & 60.0 & 32.0 & 0.050 & 13 & 1.8 & & 1094.0 & 360.0 & 520 & 1.60 & 2310 & 2377 & 106 & -107.0 & -24.0 \\
\hline $\begin{array}{l}500 \\
501\end{array}$ & $\begin{array}{r}\text { *SJ-15 } \\
S J-16\end{array}$ & 7.1 & $\begin{array}{r}22000 \\
1350\end{array}$ & 430.0 & $\begin{array}{r}5700.0 \\
54.0\end{array}$ & $\begin{array}{r}1300.0 \\
20.0\end{array}$ & 0.850 & $\begin{array}{l}25 \\
16\end{array}$ & 32.0 & & $\begin{array}{r}88.0 \\
2300.0\end{array}$ & $\begin{array}{l}830.0 \\
286.0\end{array}$ & $\begin{array}{r}48000 \\
685\end{array}$ & $\begin{array}{l}1.60 \\
0.40\end{array}$ & $\begin{array}{r}84700 \\
3550\end{array}$ & $\begin{array}{r}78306 \\
3526\end{array}$ & 99 & -79.0 & -6.7 \\
\hline 502 & SJ-17 & & $\begin{array}{r}927 \\
3600\end{array}$ & & $\begin{array}{r}27.0 \\
180.0\end{array}$ & $\begin{array}{l}12.0 \\
67.0\end{array}$ & & $\begin{array}{l}13 \\
10\end{array}$ & & & $\begin{array}{l}380.0 \\
366.0\end{array}$ & $\begin{array}{l}1670.0 \\
5000.0\end{array}$ & 54 & 1.70 & 2890 & 2879 & & & \\
\hline $\begin{array}{l}503 \\
504\end{array}$ & $\begin{array}{r}\text { SU-18 } \\
* S J-19\end{array}$ & $\begin{array}{l}7.7 \\
6.8\end{array}$ & $\begin{array}{r}3600 \\
52000\end{array}$ & $\begin{array}{r}30.0 \\
1100.0\end{array}$ & $\begin{array}{r}180.0 \\
7700.0\end{array}$ & $\begin{array}{r}67.0 \\
1600.0\end{array}$ & 1.400 & $\begin{array}{r}10 \\
5\end{array}$ & 120.0 & & $\begin{array}{r}366.0 \\
91.0\end{array}$ & $\begin{array}{l}5000.0 \\
1100.0\end{array}$ & $\begin{array}{r}2300 \\
110000\end{array}$ & 0.90 & $\begin{array}{r}11400 \\
184000\end{array}$ & $\begin{array}{r}11357 \\
173547\end{array}$ & $\begin{array}{l}98 \\
89\end{array}$ & -42.0 & 2.2 \\
\hline $\begin{array}{l}504 \\
505 \\
506\end{array}$ & $\begin{array}{r}\text { *SJ-19 } \\
S J-20 \\
S J-21\end{array}$ & $\begin{array}{l}7.0 \\
7.6\end{array}$ & $\begin{array}{r}24000 \\
1100\end{array}$ & $\begin{array}{r}440.0 \\
15.0\end{array}$ & $\begin{array}{r}5800.0 \\
35.0\end{array}$ & $\begin{array}{r}1500.0 \\
13.0\end{array}$ & 0.180 & $\begin{array}{l}23 \\
12\end{array}$ & 39.0 & & $\begin{array}{r}193.0 \\
1058.0\end{array}$ & $\begin{array}{r}2000.0 \\
710.0\end{array}$ & $\begin{array}{r}48000 \\
680\end{array}$ & $\begin{array}{r}14.00 \\
0.80\end{array}$ & $\begin{array}{r}95000 \\
3090\end{array}$ & $\begin{array}{r}81849 \\
3074\end{array}$ & $\begin{array}{r}104 \\
99\end{array}$ & -68.5 & $\begin{array}{l}2.2 \\
-5.6\end{array}$ \\
\hline 507 & $S J-22$ & 8.5 & 780 & 5.0 & 4.0 & 2.5 & 0.160 & 8 & 0.3 & & 918.0 & 820.0 & 110 & 3.70 & 2120 & 2177 & 97 & -96.5 & -13.6 \\
\hline 510 & $S J-25$ & & 119 & & 421.0 & 147.0 & & 19 & & & 174.0 & 1670.0 & 20 & 0.70 & 2490 & 2463 & & & \\
\hline 511 & SJ -26 & & $\begin{array}{l}313 \\
166\end{array}$ & & 20.0 & 14.0 & & 17 & & & 466.0 & 230.0 & 110 & 1.20 & 944 & 917 & & & \\
\hline 512 & SJ -27 & & $\begin{array}{r}166 \\
38\end{array}$ & & 33.0 & 13.0 & & 14 & & & 327.0 & 181.0 & 26 & 0.60 & 597 & 580 & & & \\
\hline $\begin{array}{l}513 \\
514\end{array}$ & $\begin{array}{l}S J-28 \\
S J-29\end{array}$ & 7.8 & 38 & 2.0 & 10.0 & 6.1 & 0.210 & 27 & 0.1 & & $\begin{array}{l}128.0 \\
130.0\end{array}$ & 10.0 & $\begin{array}{l}4 \\
6\end{array}$ & 0.30 & 145 & $\begin{array}{r}133 \\
69\end{array}$ & 111 & -78.0 & -9.5 \\
\hline 515 & $\mathrm{SJ}-30$ & 8.8 & ' & & & & & & & & & & & & & & & & \\
\hline 516 & SL-OI & & & & 62.0 & 14.0 & & 64 & & & 214.0 & 2.0 & 535 & 1.30 & 1160 & 784 & 23 & & \\
\hline 517 & $S L-02$ & 7.7 & 298 & 12.0 & 49.0 & 10.0 & 0.080 & 51. & 0.4 & 0.1 & 259.0 & & 482 & 1.40 & 1047 & 980 & 92 & & \\
\hline 518 & SL -03 & 7.4 & 4250 & 156.0 & 746.0 & 131.0 & & 32 & 1.2 & & 221.0 & 985.0 & 7470 & 3.30 & 13900 & 13883 & 101 & & \\
\hline 519 & SL -03 & 6.1 & 4380 & 207.0 & 793.0 & 138.0 & & 40 & & & 285.0 & 880.0 & 7900 & & 14500 & 14478 & 100 & & \\
\hline 520 & SL -03 & 7.6 & 4625 & 161.0 & 746.0 & 109.0 & 0.100 & 24 & 2.8 & 3.0 & 237.0 & 877.0 & 7570 & 2.90 & & 14208 & 106 & -129.0 & -16.8 \\
\hline 521 & SL-03 & 6.4 & 5167 & 172.0 & 727.0 & 103.0 & 0.160 & 28 & 2.9 & 2.6 & 313.0 & 936.0 & 8150 & 2.90 & 15730 & 15412 & 107 & & \\
\hline 522 & $\begin{array}{l}\text { SL- } 04 \\
\text { SL-05 }\end{array}$ & $\begin{array}{l}6.9 \\
7.8\end{array}$ & $\begin{array}{l}3999 \\
3660\end{array}$ & 137.0 & $\begin{array}{l}606.0 \\
668.0\end{array}$ & $\begin{array}{l}101.0 \\
157.0\end{array}$ & 0.030 & $\begin{array}{l}26 \\
29\end{array}$ & 2.4 & 2.0 & $\begin{array}{l}313.0 \\
265.0\end{array}$ & $\begin{array}{l}900.0 \\
919.0\end{array}$ & $\begin{array}{l}6660 \\
6440\end{array}$ & 2.50 & $\begin{array}{l}13365 \\
12000\end{array}$ & $\begin{array}{l}12559 \\
12003\end{array}$ & 102 & & \\
\hline & $\begin{array}{l}\text { SL-05 } \\
\text { SL-06 }\end{array}$ & $\begin{array}{l}7.8 \\
8.0\end{array}$ & $\begin{array}{l}3660 \\
2410\end{array}$ & 111.0 & $\begin{array}{l}668.0 \\
565.0\end{array}$ & 109.0 & & 18 & 1.2 & & 220.0 & 1090.0 & 4170 & 1.90 & $\begin{array}{r}12000 \\
8590\end{array}$ & $\begin{array}{r}12003 \\
8584\end{array}$ & $\begin{array}{l}100 \\
101\end{array}$ & & \\
\hline $\begin{array}{l}524 \\
525\end{array}$ & $\begin{array}{l}S L=06 \\
\text { SL-06 }\end{array}$ & 7.9 & 1558 & 52.0 & 339.0 & 69.0 & 0.140 & 12 & 0.9 & 0.6 & 263.0 & 643.0 & 2490 & 1.60 & & 5282 & 104 & -128.0 & -16.0 \\
\hline 526 & SL-06 & 7.3 & 977 & 40.0 & 240.0 & 52.0 & 0.050 & 11 & 0.7 & 0.4 & 313.0 & 489.0 & 1781 & 1.50 & 4116 & 3734 & 91 & & \\
\hline 527 & SL- 07 & 7.7 & 73 & & 57.0 & 17.0 & & 23 & & & 173.0 & 134.0 & 63 & & 452 & 379 & 57 & & \\
\hline 528 & SL-08 & 8.2 & 170 & 2.0 & 12.0 & 7.3 & 0.140 & 24 & 0.5 & & 304.0 & & 130 & 2.00 & 498 & 473 & 100 & & \\
\hline 529 & SL-08 & 7.7 & 170 & 4.0 & 12.0 & 3.8 & 0.060 & 32 & 0.3 & & 256.0 & 1.0 & 140 & 1.70 & 491 & 458 & 102 & & \\
\hline 530 & $S L-O B$ & 8.1 & 147 & 3.0 & 11.0 & 3.0 & & 24 & 0.3 & 0.1 & 292.0 & & 134 & 2.10 & 522 & 444 & 84 & & \\
\hline
\end{tabular}




\begin{tabular}{|c|c|c|c|c|c|c|c|c|c|c|c|c|c|c|c|c|c|c|c|}
\hline ID & MAP NO. & $\mathrm{pH}$ & $\mathrm{Na}$ & $\mathrm{K}$ & $\mathrm{Ca}$ & $\mathrm{Mg}$ & $\mathrm{Fe}$ & $\mathrm{SiO} 2$ & B & $\mathrm{Li}$ & $\mathrm{HCO} 3$ & SO4 & $\mathrm{Cl}$ & F & TDSm & TDSC & $\begin{array}{l}C / A \\
(q) /(\end{array}$ & $\begin{array}{r}80 \\
\left(\frac{8}{8} .\right)\end{array}$ & $\begin{array}{l}8028 \\
\left(\frac{9}{8}\right)\end{array}$ \\
\hline 531 & SL-09 & 7.9 & & & & & & & & & 260.0 & 12.0 & 138 & & 478 & 278 & & & \\
\hline 532 & SL-10 & 7.8 & 171 & & 14.0 & 3.6 & & 27 & & & 270.0 & 3.0 & 140 & & 492 & 491 & 100 & & \\
\hline 533 & SL-11 & 8.2 & 160 & 2.0 & 11.0 & 6.8 & 0.100 & 24 & & & 201.0 & 2.0 & 140 & 2.10 & 447 & 423 & 111 & & \\
\hline 534 & $S L-12$ & 7.7 & 420 & & 59.0 & 18.0 & & 42 & & & 200.0 & 23.0 & 660 & & & 1278 & 101 & & \\
\hline 535 & $S L-12$ & 7.8 & 470 & 12.0 & 70.0 & 21.0 & 0.900 & 48 & & & 185.0 & 8.0 & 840 & 1.50 & 1570 & 1514 & 96 & & \\
\hline 536 & SL- 12 & 7.7 & 416 & & 59.0 & 18.0 & & 42 & & & 200.0 & 23.0 & 664 & & 1320 & 1320 & 100 & & \\
\hline 537 & *SL-13 & 8.3 & 830 & 12.0 & 3.0 & 4.5 & 0.080 & 22 & 1.0 & & 1091.0 & 130.0 & 500 & 4.60 & 2030 & 2021 & 106 & -235.0 & -17.5 \\
\hline 538 & $S L-14$ & 7.9 & 205 & 5.0 & 14.0 & 6.0 & 0.120 & 41 & 0.4 & 0.1 & 317.0 & & 222 & 2.10 & 654 & 610 & 89 & - & 政 \\
\hline 539 & $S L-14$ & 7.9 & 200 & & 17.0 & 5.7 & & $2 \overline{6}$ & & & 280.0 & 2.0 & 200 & & & 562 & 97 & & \\
\hline 540 & SL - 15 & 8.0 & 190 & & 16.0 & 5.8 & & 42 & & & 300.0 & 7.0 & 160 & & & 526 & 99 & & \\
\hline 542 & SL-16 & 8.4 & 10200 & & 1120.0 & 601.0 & & 7 & & & 55.0 & 953.0 & 18800 & & 31800 & 31708 & 100 & & \\
\hline 542 & $S L-17$ & 7.7 & 297 & & 49.0 & 29.0 & & 23 & & & 184.0 & 3.0 & 518 & & 1010 & 712 & 27 & & \\
\hline 543 & $S L-18$ & 7.2 & 2320 & & 218.0 & 100.0 & & 28 & & & 112.0 & 95.0 & 2580 & & 4400 & 4396 & 100 & & \\
\hline 544 & SL- 19 & 7.6 & 484 & 12.0 & 73.0 & 42.0 & 0.190 & 47 & 0.4 & 0.2 & 217.0 & 3.0 & 989 & 1.20 & 1950 & 1711 & 90 & & \\
\hline 545 & * SL - 20 & 7.8 & 3000 & 23.0 & 81.0 & 92.0 & 0.200 & 25 & 0.5 & & 313.0 & 510.0 & 4100 & 1.20 & 8160 & 7962 & 108 & -132.0 & -17.0 \\
\hline 546 & $S L-21$ & 7.7 & 1000 & 19.0 & 180.0 & 60.0 & 0.460 & 53 & 0.5 & & 166.0 & 45.0 & 1900 & 1.20 & 3570 & 3287 & 101 & -133.0 & -27.3 \\
\hline 547 & $S L-21$ & 7.4 & 990 & 17.0 & 180.0 & 57.0 & 0.510 & 34 & 0.5 & 0.3 & 234.0 & 42.0 & 2060 & 1.30 & 3812 & 3463 & 91 & & \\
\hline 548 & $S L-22$ & 7.1 & 2020 & & 200.0 & 58.0 & & 41 & & & 180.0 & 57.0 & 1950 & & 3420 & 3415 & 100 & & \\
\hline 549 & SL-23 & 8.0 & 321 & 4.0 & 48.0 & 25.0 & 0.180 & 21 & 0.3 & 0.1 & 167.0 & 20.0 & 572 & 0.90 & 1160 & 1073 & 96 & & \\
\hline 550 & SL-24 & 7.3 & 190 & 60.0 & 180.0 & 170.0 & 0.030 & 47 & 0.7 & & 304.0 & 840.0 & 270 & 0.90 & 2080 & $\begin{array}{l}1864 \\
186\end{array}$ & 108 & -106.0 & -13.6 \\
\hline 551 & $S L-25$ & 7.4 & 84 & & 55.0 & 15.0 & & 25 & & & 170.0 & 130.0 & 74 & & & 442 & 100 & & 20.0 \\
\hline 552 & $S L-26$ & 8.1 & 100 & & 48.0 & 32.0 & & 53 & & & 160.0 & 130.0 & 140 & & & 529 & 101 & & \\
\hline 553 & SL-26 & 7.3 & 150 & 7.0 & 73.0 & 52.0 & & 54 & 0.1 & & 171.0 & 220.0 & 260 & 0.40 & 905 & 846 & 99 & & \\
\hline 554 & SL- 27 & 7.4 & 36 & & 48.0 & 16.0 & 0.150 & 17 & & & 295.0 & 81.0 & 36 & 0.40 & 374 & 363 & 70 & & \\
\hline 555 & SL -28 & 8.0 & 604 & & 104.0 & 55.0 & & 27 & & & 122.0 & 94.0 & 1250 & & 2240 & 2194 & 92 & & \\
\hline $\begin{array}{l}556 \\
557\end{array}$ & SL-29 & $\begin{array}{l}7.9 \\
7.8\end{array}$ & $\begin{array}{l}290 \\
260\end{array}$ & 8.0 & $\begin{array}{l}41.0 \\
36.0\end{array}$ & $\begin{array}{l}19.0 \\
23.0\end{array}$ & 0.410 & 41 & & & 198.0 & 11.0 & 470 & 0.90 & 978 & 938 & 98 & & \\
\hline $\begin{array}{l}557 \\
558\end{array}$ & & $\begin{array}{l}7.8 \\
7.3\end{array}$ & $\begin{array}{l}260 \\
945\end{array}$ & & $\begin{array}{r}36.0 \\
224.0\end{array}$ & $\begin{array}{l}23.0 \\
88.0\end{array}$ & & $\begin{array}{l}38 \\
47\end{array}$ & & & 190.0 & $\begin{array}{r}12.0 \\
\end{array}$ & $\begin{array}{r}410 \\
\end{array}$ & & & $\begin{array}{r}834 \\
3438\end{array}$ & 100 & & \\
\hline $\begin{array}{l}558 \\
559\end{array}$ & SL-31 & 7.8 & 810 & 15.0 & 230.0 & 130.0 & 0.560 & $\begin{array}{l}47 \\
24\end{array}$ & & & $\begin{array}{r}104.0 \\
65.0\end{array}$ & $\begin{array}{r}23.0 \\
29.0\end{array}$ & $\begin{array}{l}1950 \\
2100\end{array}$ & 0.60 & $\begin{array}{l}3440 \\
3370\end{array}$ & $\begin{array}{l}3438 \\
3347\end{array}$ & $\begin{array}{r}100 \\
94\end{array}$ & & \\
\hline 560 & $S L-32$ & 8.0 & 530 & 7.0 & 100.0 & 58.0 & 0.010 & 26 & 0.3 & & 120.0 & 46.0 & 1200 & 0.50 & 2070 & 1901 & 97 & & \\
\hline 561 & $S L-32$ & 7.9 & 520 & 8.0 & 110.0 & 55.0 & 0.230 & 30 & & & 106.0 & 35.0 & 1100 & 0.60 & 1910 & 1881 & 98 & & \\
\hline 562 & $S L-33$ & 7.8 & 550 & 17.0 & 95.0 & 43.0 & 1.300 & 48 & 0.3 & & 155.0 & 200.0 & 900 & 0.80 & 1990 & 1883 & 101 & -125.0 & -16.5 \\
\hline 563 & SL-34 & 8.0 & 270 & 26.0 & 31.0 & 21.0 & & 11 & 0.3 & & 244.0 & 130.0 & 310 & 0.70 & 984 & 909 & 101 & -117.0 & -14.9 \\
\hline 564 & $S L-35$ & 7.8 & 347 & & 29.0 & 15.0 & & 81 & & & 281.0 & 220.0 & 300 & & 1140 & 1130 & 101 & & \\
\hline 565 & $S L-36$ & 7.5 & 4330 & & 435.0 & 195.0 & & 18 & & & 273.0 & 254.0 & 7650 & & 13800 & 13016 & 100 & & \\
\hline 566 & $S L-38$ & 7.2 & 117 & 5.0 & 66.0 & 38.0 & & 34 & & & 143.0 & 157.0 & 255 & 0.30 & 756 & 709 & 90 & & \\
\hline 567 & $S L-39$ & 7.3 & 33 & & 18.0 & 8.0 & & 11 & & & 143.0 & 29.0 & 19 & 0.30 & 148 & 178 & 85 & & \\
\hline 568 & $S L-40$ & 7.5 & 195 & & 363.0 & 105.0 & & 57 & & & 409.0 & 284.0 & 310 & & 2370 & 1320 & 125 & & \\
\hline 569 & $S I-41$ & 7.0 & 52 & 10.0 & 56.0 & 27.0 & 0.030 & 58 & & & 239.0 & 40.0 & 103 & 0.50 & 499 & 406 & 98 & & \\
\hline 570 & SL -42 & 7.8 & 754 & 5.0 & 55.0 & 17.0 & 0.040 & 19 & 2.3 & 0.1 & 147.0 & 934.0 & 654 & 0.80 & 2609 & 2492 & 91 & & \\
\hline 571 & $S L-43$ & 7.7 & 219 & 7.0 & 35.0 & 15.0 & & 9 & 0.2 & 0.1 & 167.0 & 94.0 & 336 & 0.40 & 858 & 789 & 89 & & \\
\hline 572 & $S L-44$ & 6.9 & 354 & 7.0 & 123.0 & 27.0 & & 13 & 0.3 & & 184.0 & 27.0 & 800 & 0.20 & 1688 & 1429 & 91 & & \\
\hline 573 & $S L-45$ & 7.6 & 81 & 8.0 & 63.0 & 31.0 & & 32 & 0.1 & & 233.0 & 110.0 & 120 & 0.40 & 562 & 528 & 99 & & \\
\hline 574 & $S L-46$ & 7.5 & 191 & 16.0 & 76.0 & 25.0 & & 35 & 0.4 & & 264.0 & 191.0 & 226 & 0.80 & 891 & 891 & 99 & & \\
\hline 575 & $S L-47$ & 7.3 & 405 & 55.0 & 141.0 & 28.0 & & 50 & & & 216.0 & 378.0 & 337 & & 1500 & 1500 & 136 & & \\
\hline 576 & $S L-48$ & 5.9 & 325 & 70.0 & 128.0 & 34.0 & & 65 & & & 230.0 & 74.0 & 590 & & & 1334 & 114 & -141.0 & -15.9 \\
\hline 577 & SL -49 & 7.2 & 316 & 47.0 & 124.0 & 36.0 & & 42 & 0.8 & 0.9 & 355.0 & 94.0 & 618 & 2.30 & 1560 & 1412 & 95 & & \\
\hline 578 & SL -50 & 6.3 & 257 & 39.0 & 143.0 & 35.0 & 14.360 & 24 & 0.5 & 0.5 & 520.0 & 45.0 & 531 & 1.80 & 1308 & 1322 & 92 & & \\
\hline 579 & $S L-51$ & 6.3 & 380 & 70.0 & 136.0 & 39.0 & & 59 & & & 260.0 & 71.0 & 685 & & 1660 & 1509 & 112 & & \\
\hline 580 & SL- 52 & 7.0 & 495 & 78.0 & 154.0 & 30.0 & 0.630 & 40 & 1.6 & & 416.0 & 71.0 & 750 & 2.05 & 1754 & 1785 & 114 & & \\
\hline 581 & SL -53 & 6.2 & 370 & 55.0 & 139.0 & 32.0 & 6.940 & 45 & 1.4 & 1.6 & 480.0 & 62.0 & 708 & 2.40 & 1700 & 1611 & 93 & & \\
\hline 582 & $S L-54$ & 7.6 & 376 & 56.0 & 133.0 & 33.0 & & 47 & 1.3 & 1.6 & 355.0 & 67.0 & 722 & 2.60 & 1710 & 1564 & 98 & & \\
\hline 583 & $S L-55$ & 7.3 & 347 & 53.0 & 146.0 & 32.0 & & 77 & 1.1 & 1.3 & 459.0 & 74.0 & 673 & 2.50 & 1720 & 2553 & 94 & & \\
\hline
\end{tabular}




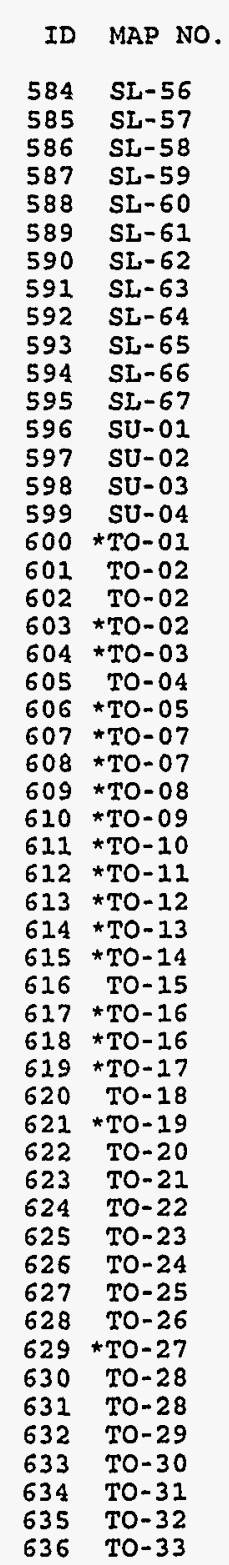

$\begin{array}{lrrrrr}\mathrm{pH} & \mathrm{Na} & \mathrm{K} & \mathrm{Ca} & \mathrm{Mg} & \mathrm{Fe} \\ 7.6 & 32 & & 65.0 & 23.0 & \\ 7.7 & 24 & & 63.0 & 25.0 & \\ 7.6 & 120 & 12.0 & 74.0 & 44.0 & 0.020 \\ 7.3 & 26 & 7.0 & 46.0 & 17.0 & \\ 7.8 & 48 & & 111.0 & 32.0 & \\ 6.9 & 39 & & 82.0 & 31.0 & \\ 6.9 & 45 & 3.0 & 97.0 & 31.0 & \\ 7.3 & 121 & 4.0 & 21.0 & 8.0 & \\ 6.8 & 220 & 28.0 & 252.0 & 69.0 & 0.220 \\ 7.2 & 267 & 18.0 & 59.0 & 11.0 & 0.370 \\ 7.6 & 105 & 15.0 & 51.0 & 11.0 & \\ 7.0 & 79 & 17.0 & 195.0 & 49.0 & 0.050 \\ 6.3 & 46 & 4.0 & 73.0 & 26.0 & 2.100 \\ 7.6 & 38 & 2.0 & 290.0 & 64.0 & 0.020 \\ 7.5 & 21 & 3.0 & 68.0 & 17.0 & 0.010 \\ 7.5 & 849 & 39.0 & 78.0 & 102.0 & 0.930 \\ 6.8 & 78000 & 3900.0 & 1800.0 & 1200.0 & \\ 7.7 & 100000 & 2000.0 & 4500.0 & 760.0 & \\ 6.3 & 66000 & 3000.0 & 1400.0 & 2700.0 & \end{array}$

$\begin{array}{rll}\text { SiO2 } & \text { B } & \text { L1 } \\ 24 & & \\ 21 & & \\ 25 & 0.2 & \\ 19 & & \\ 13 & & \\ 9 & & \\ 11 & & \\ 11 & & \\ 19 & 0.3 & 0.4 \\ 24 & 0.5 & 0.4 \\ 27 & 0.1 & \\ 39 & 0.1 & 0.1 \\ 8 & 0.1 & \\ 31 & 0.1 & \\ 37 & 0.1 & \\ 24 & 0.5 & \end{array}$

$\begin{array}{lllll}6.3 & 66000 & 3000.0 & 1400.0 & 2700.0\end{array}$

$\begin{array}{llll}7.0 & 80000 & 2000.0 & 1800.0 \quad 2000.0\end{array}$

$\begin{array}{lllll}7.0 & 57000 & 2600.0 & 1400.0 & 2800.0\end{array}$

$\begin{array}{lll}7.7 & 39000 & 1000\end{array}$

$8.0 \quad 44000 \quad 1000.01500 .02300 .0$

$100000 \quad 3800.0 \quad 1300.01900 .0$

$1100006600.0 \quad 1200.04000 .0$

$100000 \quad 7700.0 \quad 1100.04900 .0$

$1100008000.0 \quad 1100.04400 .0$

$1000007900.0 \quad 1100.04700 .0$

$71000 \quad 2600.01800 .0 \quad 1200.0$

$93000 \quad 7500.0 \quad 990.0 \quad 5400.0$

$100000 \quad 7900.0 \quad 1000.0 \quad 5200.0$

$63000 \quad 3800.0 \quad 1700.02400 .0$

$24000 \quad 1800.0 \quad 330.0 \quad 330.0$

$\begin{array}{rrrr}88000 & 3600.0 & 1200.0 & 1900.0\end{array}$

$\begin{array}{rrrrr}2200 & 130.0 & 91.0 & 71.0 & 0.030 \\ 4700 & 300.0 & 380.0 & 86.0 & \end{array}$

$1.9 \quad 32.0$

$\begin{array}{ll}2.8 & 63.0 \\ 4.9 & 73.0\end{array}$

6.870 .0

$\begin{array}{ll}4.7 & 68.0 \\ 2.2 & 21.0\end{array}$

6.671 .0

5.970 .0

$4.0 \quad 11.0$

$$
4700
$$

1.0

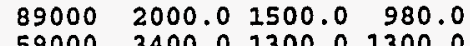

$59000 \quad 3400.0 \quad 1300.0 \quad 1300.0$

$6.9 \quad 3490 \quad 1900.0 \quad 780.0 \quad 990.0$

$\begin{array}{rrrrrrr}6.9 & 3670 & 89.0 & 321.0 & 103.0 & 0.100 & 17\end{array}$

$0.7 \quad 1.8$

$\mathrm{HCO} 3$

$250.0 \quad 40.0$

$\begin{array}{rr}248.0 & 30.0 \\ 270.0 & 180.0\end{array}$

$191.0 \quad 24.0$

304.0

330.0

199.0

139.0

20.0

$\begin{array}{rr}495.0 & 736.0 \\ 295.0\end{array}$

226.0

334.0

68.0
394.0

302.0
277.0

770.0

$\begin{array}{rr}18.0 & 35 \\ 146.0 & 1540 \\ 3900.0 & 150000 \\ 2800.0 & 220000\end{array}$

6100.0110000

5100.0130000

$5100.0 \quad 130000$

$4800.0 \quad 78000$

4900.0130000

$38.0 \quad 4100.0 \quad 170000$

$85.0 \quad 4100.0 \quad 150000$

$160.0 \quad 5700.0 \quad 180000$

$150.0 \quad 5700.0 \quad 180000$

$57.0 \quad 4600.0120000$

$170.0 \quad 7100.0 \quad 160000$

$160.0 \quad 6300.0 \quad 180000$

$120.0 \quad 6100.0 \quad 110000$

$200.0 \quad 1600.0 \quad 40000$

$\begin{array}{rrr}42.0 & 4500.0 & 150000 \\ 180.0 & 240.0 & 3400\end{array}$

$42.0 \quad 960.0 \quad 9100$

$\begin{array}{ll}1.4 & 16.0 \\ 3.0 & 16.0\end{array}$

$37.0 \quad 4600.0 \quad 140000$

$49.0 \quad 3200.0 \quad 96000$

$\begin{array}{lll}66.0 & 2200.0 \quad 76000\end{array}$

$\begin{array}{lll}319.0 & 152.0 & 6000 \\ 325.0 & 148.0 & 6280\end{array}$

F

TDSC

0.70

365

$\underset{(\xi)}{C / A}(q.) \quad(z .)^{\delta 01 B}$

0.30

0.30

0.40

0.60

0.80

0.20

0.30

0.40

0.10

33
307
24500
240000

240000
205000

236000

157000

144000

218000

181000

297000

313000

314000

314000

304000

310000

195000

70200

249000
6260

364100

$\begin{array}{rr}318 & 83 \\ 713 & 103\end{array}$

$274 \quad 94$

$\begin{array}{rr}590 & 101 \\ 517 & 82\end{array}$

$582 \quad 82$

404
1853
99

$\begin{array}{lr}959 & 91 \\ 496 & 103\end{array}$

$1119 \quad 88$

106

$\begin{array}{rr}1345 & 97 \\ 298 & 97\end{array}$

2833

23880

74

$221800 \quad 100$

$220900 \quad 100$

$146600 \quad 123$

$232600 \quad 113$

$154400 \quad 75$
281729

$\begin{array}{rr}95 \\ 275942 & 123\end{array}$

$299479 \quad 96$

$308959 \quad 104$

$299474 \quad 96$

$201228 \quad 96$

$274074 \quad 101$

$300479 \quad 96$

887059

249221

$6222 \quad 105$

$15500 \quad 15547 \quad 85$

251000

171000

$238098 \quad 100$

133000

12924101

$10307 \quad 100$

10772100

$\begin{array}{lllll}7.7 & 2250 & 105.0 & 130.0 & 80.0\end{array}$

$15 \quad 0.8$

$175.0 \quad 300.0 \quad 4200$

0.22

7151

$89-112.0-13.8$

B -13 


\begin{tabular}{|c|c|c|c|c|c|c|c|c|c|c|c|c|c|c|c|c|c|c|}
\hline ID & MAP NO. & $\mathrm{pH}$ & $\mathrm{Na}$ & $\mathrm{K}$ & $\mathrm{Ca}$ & $\mathrm{Mg}$ & $\mathrm{Fe}$ & SiO2 & B & Li & $\mathrm{HCO} 3$ & SO4 & $\mathrm{Cl}$ & F & TDSm & TDSC & $\begin{array}{l}C / A \quad \delta D \\
(z)(q .)\end{array}$ & $\begin{array}{l}8018 \\
(8 .)\end{array}$ \\
\hline $\begin{array}{l}637 \\
638 \\
639\end{array}$ & $\begin{array}{l}\text { TO- } 34 \\
\text { TO-35 } \\
\text { TO-36 }\end{array}$ & & & & & & & & & & & & & & & & & \\
\hline 640 & TO-37 & 6.8 & 49000 & 2500.0 & 1700.0 & 1600.0 & & & & & & 5600.0 & 69000 & & & 129400 & 116 & \\
\hline 641 & $\star \mathrm{TO}-38$ & 7.2 & 37000 & 2500.0 & 2500.0 & 2800.0 & & & & & & 5800.0 & 70000 & 9.20 & & 120609 & 96 & \\
\hline 642 & $*$ TO-39 & 6.9 & 51000 & 1800.0 & 880.0 & 1900.0 & & & & & & 5700.0 & 70000 & & & 131280 & 117 & \\
\hline $\begin{array}{l}643 \\
644\end{array}$ & $\begin{array}{l}\text { TO- } 40 \\
\text { TO- } 41\end{array}$ & 8.5 & 50000 & 1900.0 & 1500.0 & 450.0 & & & & & & 3000.0 & 78000 & & & 134850 & 103 & \\
\hline 645 & TO- 42 & & & & & & & & & & & & & & & & & \\
\hline 646 & $\star T O-43$ & 7.1 & 54000 & 3200.0 & 3000.0 & 3400.0 & & & & & & 5700.0 & 99000 & 13.00 & & 168313 & 98 & \\
\hline 647 & *TO- 44 & 6.7 & 78000 & 2900.0 & 1700.0 & 2500.0 & & & & & & 6600.0 & 98000 & & & 189700 & 129 & \\
\hline 648 & $\star T O-45$ & 6.9 & 72000 & 2600.0 & 1300.0 & 2500.0 & & & & & & & & & & 78400 & & \\
\hline 649 & *TO-46 & & 100000 & 5100.0 & 1300.0 & 2900.0 & & & 2.8 & 45.0 & 85.0 & 5200.0 & 170000 & & 295000 & 284542 & 97 & \\
\hline 650 & TO- 47 & & 100000 & 8000.0 & 1100.0 & 5300.0 & & & 5.7 & 75.0 & 170.0 & 5800.0 & 180000 & & 305000 & 300284 & 97 & \\
\hline 651 & *TO-48 & & 110000 & 5700.0 & 1100.0 & 3400.0 & & & 3.9 & 51.0 & 75.0 & 5500.0 & 190000 & & 329000 & 315737 & 96 & \\
\hline 652 & $\star$ TO -49 & & 100000 & 9200.0 & 1100.0 & 5700.0 & & & 6.8 & 90.0 & 140.0 & 5300.0 & 180000 & & 312000 & 301369 & 98 & \\
\hline 653 & *TO- 50 & & 95000 & 4200.0 & 1400.0 & 2100.0 & & & 2.6 & 36.0 & 53.0 & 4500.0 & 160000 & & 280000 & 267226 & 97 & \\
\hline 654 & $* T O-51$ & & 100000 & 8400.0 & 1200.0 & 4600.0 & & & 7.7 & 75.0 & 130.0 & 5000.0 & 180000 & & 323000 & 299264 & 96 & \\
\hline 655 & $\star \mathrm{TO}-52$ & & 110000 & 7000.0 & 1300.0 & 3000.0 & & & 6.8 & 55.0 & 60.0 & 4300.0 & 190000 & & 328000 & 315630 & 96 & \\
\hline 656 & TO- 53 & & 110000 & 2400.0 & 1500.0 & 960.0 & & & 1.7 & 17.0 & 33.0 & 4100.0 & 180000 & & 302000 & 298976 & 96 & \\
\hline 657 & TO- 54 & & 120000 & 2900.0 & 1400.0 & 1400.0 & & & 2.5 & 22.0 & 42.0 & 4000.0 & 190000 & & 324000 & 319721 & 100 & \\
\hline 658 & *TO- 55 & & 110000 & 7000.0 & 1100.0 & 3900.0 & & & 6.6 & 61.0 & 120.0 & 5000.0 & 190000 & & 321000 & 317059 & 97 & \\
\hline 659 & $\star T 0-56$ & & 110000 & 7600.0 & 1100.0 & 4100.0 & & & 7.0 & 69.0 & 100.0 & 5100.0 & 180000 & & 317000 & 307949 & 103 & \\
\hline 660 & TO. 57 & 7.5 & 2000 & 120.0 & 79.0 & 63.0 & 0.010 & 42 & & & 212.0 & 190.0 & 3100 & 1.80 & 5700 & 5658 & 104 & \\
\hline 661 & TO- 58 & & 1100 & 66.0 & 49.0 & 39.0 & & & 0.7 & 0.9 & 190.0 & 180.0 & 2500 & & 4330 & 4027 & 71 & \\
\hline 662 & TO-59 & & & & & & & & & & & & & & & & & \\
\hline 663 & TO-60 & & 2300 & 150.0 & 100.0 & 84.0 & & & 1.0 & 1.5 & 180.0 & 240.0 & 3700 & & 6760 & 6663 & 103 & \\
\hline 664 & TO-62 & & 3700 & 210.0 & 200.0 & 59.0 & & & 1.4 & 1.5 & 270.0 & 420.0 & 5000 & & 9470 & 9722 & 117 & \\
\hline 665 & TO- 62 & & 2100 & 100.0 & 100.0 & 80.0 & & & & 1.2 & & 300.0 & 3700 & & & 6380 & & \\
\hline 666 & TO- 62 & & 2700 & 130.0 & 160.0 & 110.0 & & & 1.2 & 1.8 & 180.0 & 340.0 & 4600 & & 8740 & 8129 & 98 & \\
\hline 667 & TO-63 & & 50800 & 2210.0 & 1650.0 & 1540.0 & & & & 8.8 & & 6840.0 & 80300 & & & 143340 & & \\
\hline $\begin{array}{l}668 \\
669\end{array}$ & $\begin{array}{l}\text { TO- } 64 \\
\text { TO- } 65\end{array}$ & & & & & & & & & & & & & & & & & \\
\hline 670 & TO-66 & & & & & & & & & & & & & & & & & \\
\hline 671 & TO-67 & 7.5 & 894 & & 112.0 & 44.0 & & 30 & & & 231.0 & 66.0 & 1520 & & 2780 & 2750 & & \\
\hline 672 & TO-68 & & & & & & & & & & & & & & & & & \\
\hline 673 & TO-69 & 7.8 & & & & & & & & & 124.0 & & 510 & & & 571 & & \\
\hline 674 & TO-69 & & & & & & & & & & & & & & & & & \\
\hline 675 & TO- 70 & 7.1 & 300 & 9.0 & 120.0 & 54.0 & & 28 & 0.2 & & 230.0 & 88.0 & 650 & 0.40 & 1370 & 1334 & 99 & \\
\hline 676 & TO-71 & & & & & & & & & & & & & & & & & \\
\hline 677 & TO- 72 & & 900 & 19.0 & 220.0 & 93.0 & & 30 & 0.2 & & 190.0 & 100.0 & 1900 & 0.50 & 3360 & 3326 & 99 & \\
\hline 678 & TO- 72 & 7.6 & & & & & & & & & 208.0 & & 1700 & & & 1802 & & \\
\hline 679 & To-73 & 7.7 & 204 & & 74.0 & 34.0 & & 28 & & & 252.0 & 91.0 & 332 & & 889 & 859 & & \\
\hline 680 & TO-74 & & & & & & & & & & & & & & & & & \\
\hline 681 & TO-75 & & & & & & & & & & & & & & & & & \\
\hline 682 & TO-76 & & & & & & & & & & & & & & & & & \\
\hline 683 & TO-77 & & & & & & & & & & & & & & & & & \\
\hline 684 & TO- 78 & & & & & & & & & & & & & & & & & \\
\hline 685 & TO- 79 & & & & & & & & & & & & & & & & & \\
\hline 686 & TO- 80 & & 9000 & 270.0 & 750.0 & 200.0 & & 26 & 1.7 & & 220.0 & 630.0 & 16000 & 1.00 & 27000 & 26959 & 96 & \\
\hline 687 & TO- 80 & 7.5 & 8900 & 240.0 & 580.0 & 290.0 & & 27 & 0.2 & & 230.0 & 660.0 & 15000 & 1.70 & 26700 & 25685 & 99 & \\
\hline 688 & TO- 80 & 7.7 & 7500 & 210.0 & 250.0 & 150.0 & 0.100 & 26 & 1.6 & & 205.0 & 500.0 & 11800 & 0.34 & & 20511 & $102-107.0$ & -13.8 \\
\hline 689 & TO-80 & 7.5 & 8910 & 237.0 & 584.0 & 188.0 & 0.007 & 27 & 3.5 & & 233.0 & 662.0 & 15000 & 1.70 & 25800 & 25697 & 99 & \\
\hline
\end{tabular}




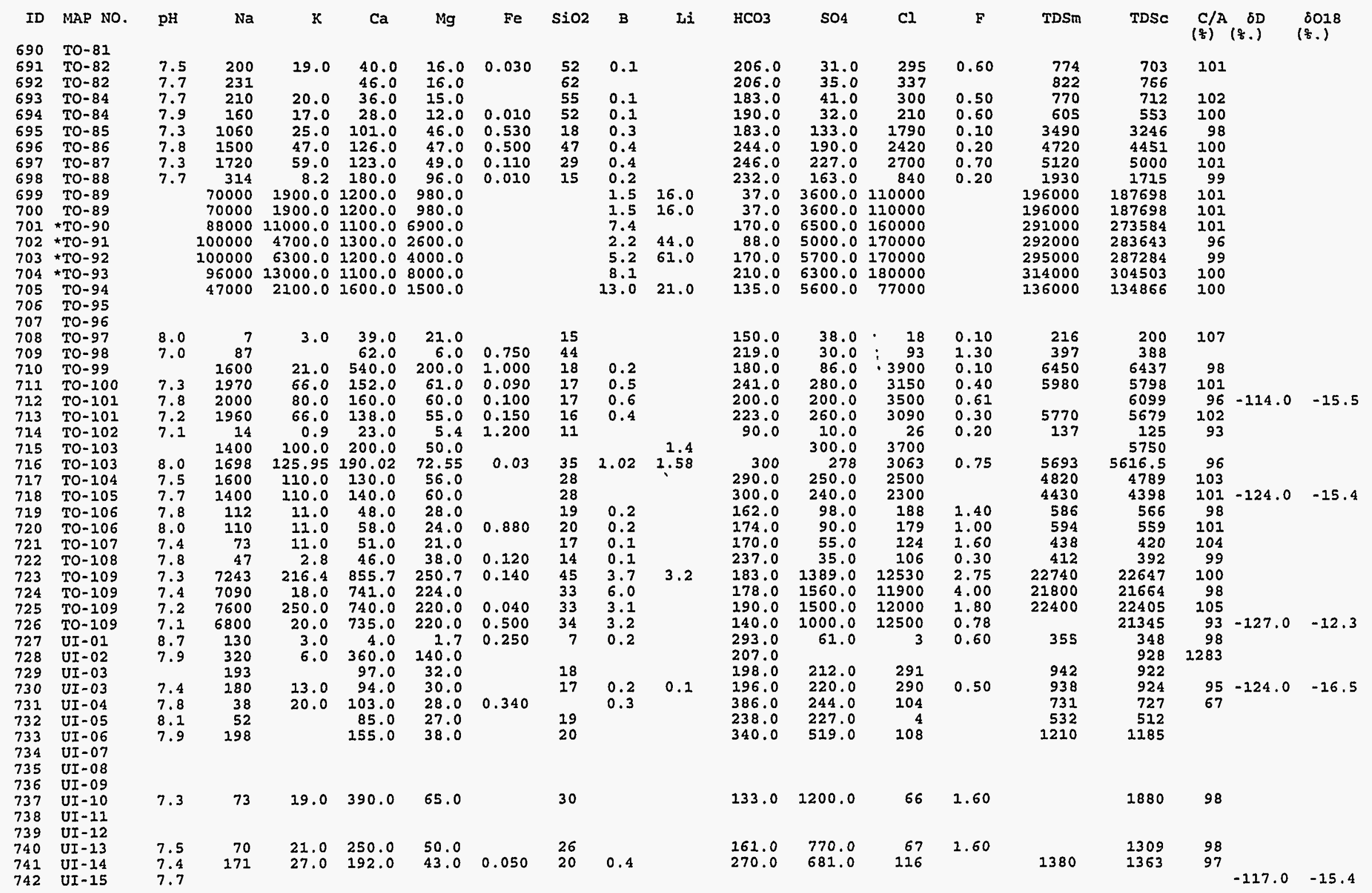




\begin{tabular}{|c|c|c|c|c|c|c|c|c|c|c|c|c|c|c|c|c|c|c|c|}
\hline ID & MAP NO. & $\mathrm{pH}$ & $\mathrm{Na}$ & $\mathrm{K}$ & $\mathrm{Ca}$ & $\mathrm{Mg}$ & $\mathrm{Fe}$ & $\mathrm{SiO} 2$ & B & $\mathrm{L} 1$ & $\mathrm{HCO} 3$ & $\mathrm{SO} 4$ & $\mathrm{Cl}$ & $\mathbf{F}$ & TDSm & TDSC & $\begin{array}{l}C / A \\
(g)\end{array}$ & $\begin{array}{r}\delta D \\
(8 .)\end{array}$ & $\begin{array}{l}\delta 018 \\
\left(\frac{8}{8} .\right)\end{array}$ \\
\hline 743 & UI -16 & 7.1 & 104 & & 357.0 & 75.0 & & 10 & & & 142.0 & 1150.0 & 80 & & 1990 & 1835 & & & \\
\hline 744 & UI -16 & 7.6 & 91 & 23.0 & 367.0 & 69.0 & & 24 & & & 239.0 & 1150.0 & 78 & 1.80 & 2000 & 1872 & 100 & & \\
\hline 745 & UI -17 & 7.5 & & & & & & & & & & & & & & & 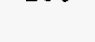 & & \\
\hline 746 & UI - 18 & 7.5 & & & & & & & & & & & & & & & & & \\
\hline 747 & UI - 19 & $\begin{array}{l}7.5 \\
7.5\end{array}$ & & & & & & & & & & & & & & & & & \\
\hline $\begin{array}{l}748 \\
749\end{array}$ & $\begin{array}{l}U I-20 \\
U I-21\end{array}$ & 7.5 & & & & & & & & & & & 31000 & & & 31000 & & & \\
\hline 750 & UI - 22 & 8.6 & 16600 & 62.0 & 2.0 & 1.2 & & 12 & 360.0 & & 5940.0 & 400.0 & 21500 & 46.00 & 41800 & 41532 & 101 & & \\
\hline 751 & UI - 23 & 7.5 & 41000 & 60.0 & & 0.2 & 0.300 & & 240.0 & 0.3 & 128018.0 & 3500.0 & 650 & 450.00 & 109000 & 108607 & 81 & & \\
\hline 752 & $U I-24$ & 9.5 & 34000 & 39.0 & 3.0 & 1.0 & 0.320 & & 180.0 & & 96684.0 & 7400.0 & 3100 & 26.00 & 92300 & 92109 & 81 & & \\
\hline 753 & UI -25 & 8.6 & 880 & 2.0 & 2.0 & 0.7 & 0.020 & 17 & 18.0 & 0.4 & 1756.0 & 18.0 & 350 & 28.00 & 2230 & 2144 & 98 & -132.0 & -16.9 \\
\hline $\begin{array}{l}754 \\
755\end{array}$ & $\begin{array}{l}U I-26 \\
U I-26\end{array}$ & 8.3 & 900 & 4.0 & 2.0 & 0.2 & 0.100 & 17 & 11.0 & 0.4 & 2590.0 & 210.0 & 380 & & 2310 & 2178 & 100 & & \\
\hline 756 & UI -27 & 8.0 & 1400 & 5.0 & 2.0 & 1.0 & 0.060 & 17 & 18.0 & & 1870.0 & 82.0 & 990 & 19.00 & & 3419 & 102 & & \\
\hline 757 & UI -28 & 8.5 & 3100 & 11.0 & 4.0 & 1.0 & & 15 & 21.0 & 0.6 & 1950.0 & 100.0 & 3300 & 25.00 & 7880 & 7500 & 106 & & \\
\hline 758 & UI - 28 & 8.0 & 2600 & 10.0 & 3.0 & 0.9 & 0.060 & 15 & 18.0 & & 2340.0 & 38.0 & 2600 & 21.00 & & 6424 & 100 & & \\
\hline 759 & $U I-28$ & 8.3 & 2400 & 11.0 & 2.0 & 1.2 & 0.090 & 15 & 20.0 & 0.6 & 780.0 & 140.0 & 3200 & & 7860 & 6138 & 98 & & \\
\hline 760 & $U I-28$ & 8.3 & 2400 & 11.0 & 2.1 & 1.2 & 0.090 & 15 & 20.0 & 0.6 & 779.0 & 140.0 & 3200 & 2.00 & 6190 & 6139 & 98 & & \\
\hline 761 & UI-29 & 8.3 & 1200 & 4.0 & 3.0 & 0.9 & 0.060 & 16 & 4.9 & & 2630.0 & 130.0 & 300 & 10.00 & & 2941 & 96 & & \\
\hline 762 & UI - 30 & 7.8 & 420 & 1.0 & 1.0 & 0.9 & 0.210 & 16 & 0.8 & 0.3 & 890.0 & 32.0 & 82 & 4.40 & 1090 & 979 & 104 & & \\
\hline 763 & $U I-31$ & 8.8 & 420 & 1.0 & 5.8 & 0.7 & 0.040 & 14 & 0.1 & 0.1 & 602.0 & 310.0 & 36 & 2.80 & 1140 & 1072 & 107 & & \\
\hline 764 & UI - 32 & 9.0 & 410 & 1.0 & 2.0 & 0.5 & 0.020 & 16 & 0.6 & 0.1 & 510.0 & 390.0 & 31 & 2.00 & 1150 & 1087 & 103 & & \\
\hline 765 & $U I-32$ & 8.3 & 400 & 1.1 & 1.9 & 0.8 & 0.020 & 15 & 0.7 & 0.1 & 568.0 & 360.0 & 33 & 2.00 & 1100 & 1078 & 99 & & \\
\hline 766 & UI - 32 & & 410 & 0.9 & 1.7 & 0.5 & 0.020 & 16 & 0.6 & 0.1 & 510.0 & 390.0 & 31 & 2.00 & 1150 & 1087 & 103 & & \\
\hline 767 & UI - 33 & 8.6 & 450 & 2.0 & 3.0 & 1.2 & 0.140 & 13 & 0.4 & 0.1 & 600.0 & 350.0 & 92 & 2.20 & 1260 & 1196 & 100 & -133.0 & -17.3 \\
\hline 768 & UI -33 & 8.8 & 390 & 1.0 & 1.0 & 0.5 & & 12 & 0.2 & & 524.0 & 390.0 & 22 & 1.10 & 1080 & 1063 & 98 & -133.0 & -17.3 \\
\hline 769 & UI - 33 & 8.2 & 2300 & 10.0 & 9.0 & 5.3 & 0.160 & 10 & 3.2 & 0.5 & 1180.0 & 270.0 & 2900 & 4.90 & 6110 & 6080 & 94 & -133.0 & -17.3 \\
\hline 770 & $U I-33$ & 8.7 & 480 & 2.0 & 2.0 & 0.9 & 0.130 & 13 & 0.4 & 0.1 & 610.0 & 380.0 & 110 & 2.10 & 1320 & 1277 & 100 & -133.0 & -17.3 \\
\hline 771 & UI - 34 & 8.3 & 420 & 1.0 & 3.0 & 0.4 & 0.020 & 14 & 0.8 & 0.1 & 740.0 & 290.0 & 23 & 3.80 & 1140 & 1105 & 98 & & \\
\hline 772 & UI - 34 & & 420 & 1.1 & 3.4 & 0.4 & 0.020 & 14 & 0.8 & 0.1 & 742.0 & 290.0 & 23 & & 1130 & 1103 & 98 & & \\
\hline 773 & UI - 34 & & 430 & 1.0 & 1.9 & 0.7 & 0.040 & 13 & 0.9 & 0.1 & 693.0 & 300.0 & 22 & 4.70 & 1150 & 1101 & 103 & & \\
\hline 774 & UI - 35 & 8.3 & 390 & 1.1 & 1.9 & 0.2 & 0.020 & 14 & 0.5 & 0.1 & 574.0 & 350.0 & 27 & 2.00 & 1070 & 1054 & 97 & & \\
\hline 775 & $U I-35$ & 8.9 & 390 & 0.9 & 3.0 & 0.2 & 0.030 & 14 & 0.5 & 0.1 & 498.0 & 380.0 & 25 & 2.10 & 1110 & 1046 & 102 & & \\
\hline 776 & UI - 35 & 8.3 & 390 & 1.0 & 2.0 & 0.2 & 0.020 & 14 & 0.5 & 0.1 & 570.0 & 350.0 & 27 & 2.00 & 1110 & 1052 & 98 & & \\
\hline 777 & UI-36 & & 360 & 2.0 & 5.0 & 0.7 & 0.170 & 12 & 0.3 & & 620.0 & 260.0 & 13 & 1.20 & 958 & 947 & 100 & & \\
\hline 778 & UI -37 & 8.6 & 340 & 1.0 & 5.0 & 1.8 & 2.100 & 8 & 0.1 & & 370.0 & 400.0 & 7 & 0.50 & 948 & 939 & 104 & & \\
\hline 779 & $U I-38$ & 8.0 & & & & & & & & & & & & & & & & & \\
\hline 780 & UI-39 & 7.7 & 220 & 1.0 & 1.0 & 0.3 & & 8 & 0.1 & & 380.0 & 50.0 & 87 & 1.80 & 555 & 548 & 99 & & \\
\hline 781 & $U I-40$ & 7.5 & & & & & & & 11.0 & & & & & & & & & & \\
\hline 782 & UT-01 & 6.9 & 213 & & 182.0 & 55.0 & & 26 & & & 233.0 & 438.0 & 352 & & 1380 & 1168 & 60 & & \\
\hline 783 & UT-02 & 7.5 & & & 128.0 & 44.0 & & 36 & & & 255.0 & 266.0 & 218 & & 1060 & 817 & 63 & & \\
\hline 784 & UT-03 & & & & & & & & & & & & & & & & & & \\
\hline 785 & UT - 04 & 7.0 & 204 & & 180.0 & 51.0 & & 34 & & & 330.0 & 386.0 & 302 & & 1320 & 1115 & 60 & & \\
\hline 786 & UT-05 & 7.3 & 235 & & 191.0 & 52.0 & & 28 & & & 320.0 & 441.0 & 338 & & 1440 & 1442 & 100 & & \\
\hline 787 & UT - 06 & 7.2 & 246 & & 192.0 & 50.0 & & 27 & & & 339.0 & 448.0 & 338 & & 1570 & 1468 & 100 & & \\
\hline 788 & UT -07 & 7.0 & 220 & 23.0 & 180.0 & 49.0 & 0.030 & 26 & 0.5 & 0.4 & 317.0 & 420.0 & 320 & 0.20 & 1440 & 1368 & 100 & -124.0 & -16.6 \\
\hline 789 & UT-08 & 7.1 & 229 & & 179.0 & 55.0 & & 21 & & & 317.0 & 413.0 & 343 & 1.80 & 1510 & 1169 & 57 & & \\
\hline 790 & UT -09 & 6.7 & 225 & 23.0 & 186.0 & 48.0 & 0.080 & 25 & 0.4 & 0.3 & 367.0 & 424.0 & 329 & 2.10 & 1436 & 1418 & $97-$ & -137.0 & -16.0 \\
\hline 791 & UT - 10 & 6.8 & 223 & 24.0 & 234.0 & 49.0 & 0.270 & 25 & 0.4 & 0.3 & 351.0 & 417.0 & 325 & 2.10 & 1446 & 1447 & 110 & -137.0 & -16.0 \\
\hline 792 & UT-11 & 6.8 & 225 & 23.0 & 193.0 & 48.0 & 0.140 & 25 & 0.4 & 0.3 & 376.0 & 422.0 & 339 & 2.00 & 1428 & 1437 & $97-$ & -137.0 & -16.0 \\
\hline 793 & UT-11 & 7.4 & 210 & 24.0 & 88.0 & 49.0 & 0.300 & 21 & 0.9 & & 260.0 & 300.0 & 430 & 1.00 & & 1230 & $80-$ & -137.0 & -16.0 \\
\hline 794 & UT - 12 & & 197 & & 158.0 & 52.0 & & 29 & & & 310.0 & 328.0 & 312 & & 1990 & 1031 & 59 & & \\
\hline 795 & UT -13 & & & & & & & & & & & & & & & & & & \\
\hline
\end{tabular}




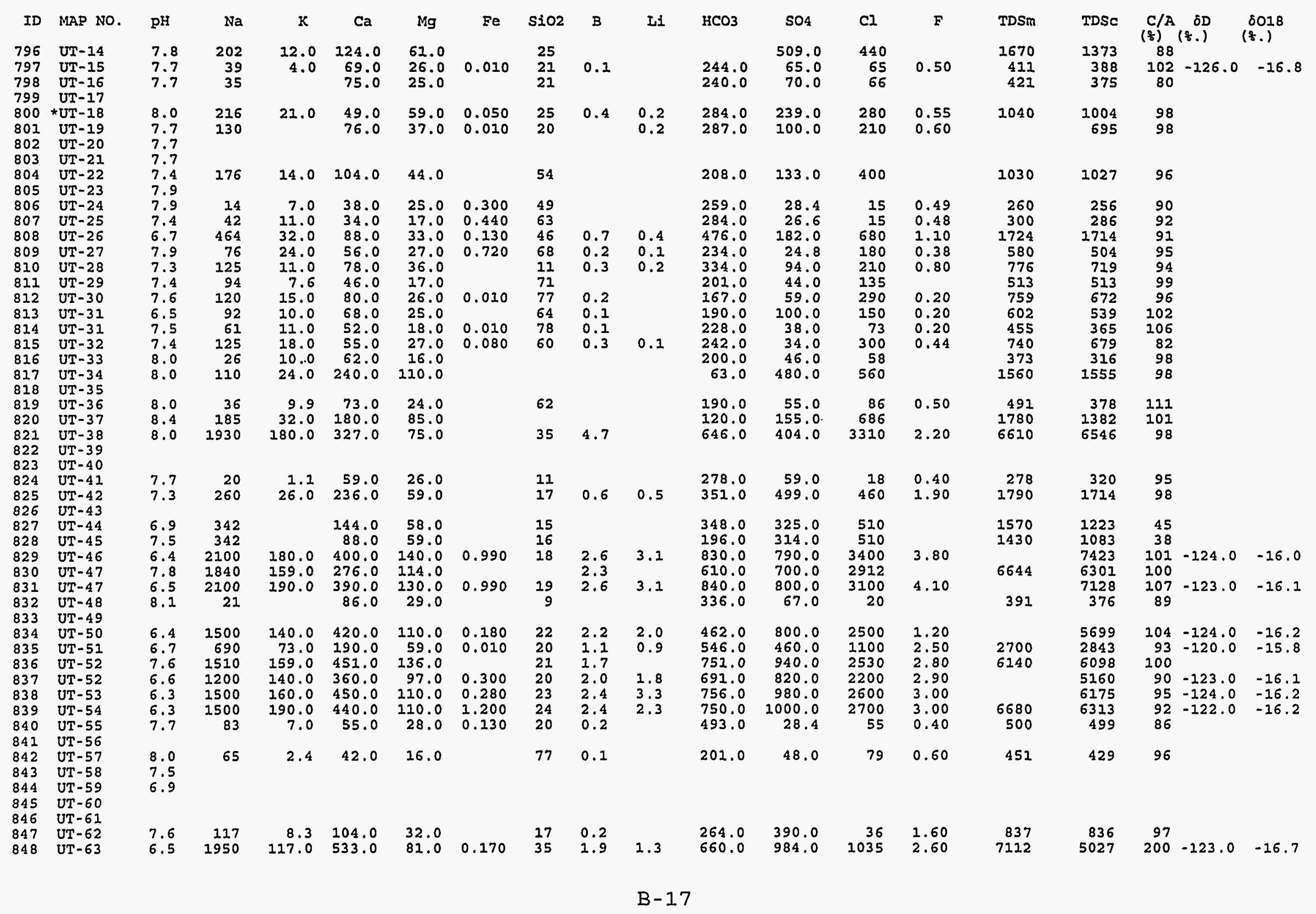




\begin{tabular}{|c|c|c|c|c|c|c|c|c|c|c|c|c|c|c|c|c|c|c|c|}
\hline ID & MAP NO. & $\mathrm{pH}$ & $\mathrm{Na}$ & K & $\mathrm{Ca}$ & Mg & $\mathrm{Fe}$ & $\mathrm{SiO2}$ & B & $\mathrm{Li}$ & $\mathrm{HCO} 3$ & $\mathrm{SO} 4$ & $\mathrm{Cl}$ & F & TDSm & TDSc & $\begin{array}{l}C / A \\
(8)\end{array}$ & $\begin{array}{c}\delta D \\
(z .)\end{array}$ & $\begin{array}{l}\delta 018 \\
(8 .)\end{array}$ \\
\hline 849 & UT -63 & 6.6 & 970 & 70.0 & 262.0 & 43.0 & 0.030 & 31 & 0.9 & 0.6 & 509.0 & 1516.0 & 2580 & 2.90 & 3640 & 5694 & 53 & -123.0 & -16.7 \\
\hline 850 & UT - 63 & 7.0 & 1350 & 93.0 & 155.0 & 60.0 & 0.100 & 15 & 1.5 & & 415.0 & 800.0 & 2850 & 1.30 & & 5513 & 71 & -123.0 & -26.7 \\
\hline 851 & UT -63 & 7.9 & 1680 & 10.0 & 469.0 & 80.0 & & 30 & 1.4 & & 542.0 & 1400.0 & 2320 & 3.60 & 6360 & 6261 & 100 & & \\
\hline 852 & $U T-64$ & 6.7 & 1117 & 22.0 & 79.0 & 13.0 & & 42 & 0.6 & 0.2 & 426.0 & 425.0 & 1300 & 1.40 & 3094 & 3167 & 103 & & \\
\hline 853 & UT -65 & 7.1 & 351 & 20.0 & 93.0 & 37.0 & & 22 & 0.2 & 0.2 & 317.0 & 95.0 & 1953 & 1.00 & 1298 & 2706 & 37 & & \\
\hline $\begin{array}{l}854 \\
855\end{array}$ & $\begin{array}{l}\text { UT }-66 \\
\text { UT }-67\end{array}$ & 6.7 & 301 & 16.0 & 84.0 & 36.0 & & 23 & & & 350.0 & 94.0 & 475 & & 1200 & 1201 & 98 & & \\
\hline 856 & UT -68 & & & & & & & & & & & & & & & & & & \\
\hline 857 & UT -69 & 7.4 & 460 & 38.0 & 220.0 & 54.0 & 0.070 & 36 & 0.4 & & 365.0 & 120.0 & 860 & 0.30 & 1860 & 1822 & 94 & & \\
\hline 858 & UT - 70 & 7.1 & 306 & 9.93 & 17.29 & 4.75 & 0.08 & 43 & 0.9 & 0.21 & 613 & 46 & 153 & 2.88 & 928 & 887 & 96 & & \\
\hline 859 & WA- 01 & 7.5 & 9 & 3.0 & 23.0 & 4.4 & 0.020 & 23 & & & 106.0 & 5.0 & 5 & 0.30 & 125 & 102 & 99 & & \\
\hline 860 & WA- 02 & 7.6 & 13 & & 51.0 & 16.0 & & 26 & & & 222.0 & 17.0 & 14 & & 246 & 233 & 88 & & \\
\hline 861 & WA-03 & 7.4 & 180 & 9.0 & 90.0 & 40.0 & 0.010 & 14 & & 0.1 & 234.0 & 280.0 & 260 & 0.30 & 1000 & 974 & 93 & & \\
\hline 862 & WA- 04 & & & & & & & & & & & & & & & & & & \\
\hline 863 & WA- 05 & 7.9 & 8 & & 58.0 & 23.0 & & 28 & & & 228.0 & 18.0 & 33 & & 295 & 280 & 102 & & \\
\hline 864 & WA- 06 & 7.9 & 32 & 4.4 & 59.0 & 29.0 & & 30 & 0.1 & & 220.0 & 100.0 & 30 & 0.60 & 402 & 393 & 104 & & \\
\hline 865 & $W A-06$ & 7.5 & 32 & 3.8 & 56.3 & 28.4 & & 38 & & & 245.0 & 86.0 & 30 & 0.34 & 408 & 356 & 99 & & \\
\hline 866 & WA-07 & 5.9 & 1587 & 120.0 & 740.0 & 130.0 & & 27 & 2.4 & 1.6 & 1104.0 & 1802.0 & 2250 & 2.70 & 7388 & 7175 & 100 & & \\
\hline 867 & WA-07 & 6.1 & 2130 & 167.8 & 760.1 & 156.1 & & 27 & 4.8 & 2.4 & 1238.0 & 1841.0 & 3195 & 3.00 & 9075 & 8907 & 100 & & \\
\hline 868 & WA-07 & 7.2 & 2530 & 220.0 & 643.0 & 128.0 & & 28 & 4.8 & & 721.0 & 1990.0 & 3620 & 2.60 & 9530 & 9521 & 102 & & \\
\hline 869 & *WA-07 & 7.1 & 2090 & 170.0 & 75.0 & 140.0 & 0.100 & 24 & 5.6 & & 1090.0 & 1500.0 & 3800 & 0.84 & & 8312 & 70 & -111.0 & -13.1 \\
\hline 870 & WA-08 & 7.1 & 1033 & 107.0 & 417.0 & 79.0 & & 24 & 1.3 & & 598.0 & 937.0 & 1700 & 2.50 & 5060 & 4594 & 97 & & \\
\hline 871 & WA- 09 & 8.3 & 13 & 3.0 & 35.0 & 12.0 & 0.030 & 14 & 0.2 & 0.1 & 117.0 & 59.0 & 15 & 0.70 & 226 & 210 & 103 & & \\
\hline 872 & WA- 10 & 7.6 & 15 & 6.0 & 65.0 & 14.0 & 0.010 & 22 & 0.1 & & 238.0 & 37.0 & 17 & 0.30 & 296 & 271 & 100 & & \\
\hline 873 & WA-11 & 7.7 & 37 & 2.0 & 46.0 & 27.0 & & 15 & & & 154.0 & 106.0 & 44 & 0.30 & 382 & 338 & 203 & & \\
\hline 874 & $W A-12$ & 8.0 & 80 & 9.8 & 200.0 & 72.0 & & & 0.4 & & 182.0 & 667.0 & 64 & 0.80 & 1180 & 2183 & 105 & & \\
\hline 875 & WA -13 & 7.9 & 24 & & 172.0 & 90.0 & & 24 & & & 188.0 & 562.0 & 70 & & 1300 & 1034 & 102 & & \\
\hline 876 & $W A-14$ & 7.3 & 62 & 8.0 & 150.0 & 79.0 & 0.020 & 27 & 0.2 & & 232.0 & 550.0 & 58 & 0.40 & 1060 & 1021 & 99 & & \\
\hline 877 & WA-15 & 7.8 & 71 & 8.0 & 161.0 & 90.0 & & 23 & 0.2 & 0.1 & 202.0 & 636.0 & 86 & 0.30 & 1284 & 2152 & 98 & & \\
\hline 878 & WA- 26 & 8.2 & 29 & & 52.0 & 23.0 & & 15 & & & 254.0 & 62.0 & 68 & 0.30 & 318 & 310 & 100 & & \\
\hline 879 & $W A-17$ & & 180 & 29.0 & 96.0 & 18.0 & & 19 & 0.7 & & 200.0 & 480.0 & 48 & 2.40 & 962 & 942 & 99 & & \\
\hline 880 & WA -17 & 7.0 & 176 & 19.0 & 90.0 & 18.0 & 0.060 & 20 & 0.5 & 0.2 & 197.0 & 462.0 & 41 & 2.70 & 952 & 906 & 100 & & \\
\hline 881 & WA-18 & 7.7 & 9 & 3.1 & 62.0 & 22.0 & & 18 & & & 189.0 & 86.0 & 17 & 0.30 & 338 & 293 & 100 & & \\
\hline 882 & WA- 19 & & 283 & 25.0 & 100.0 & 22.0 & & & 0.8 & & 214.0 & 415.0 & 285 & 1.60 & 1240 & 1238 & 97 & & \\
\hline 883 & WA- 29 & 7.0 & 274 & 24.1 & 104.0 & 22.7 & & 22 & 0.4 & 0.3 & 234.0 & 404.0 & 270 & 1.29 & 1248 & 1215 & 98 & & \\
\hline 884 & WA- 20 & 7.6 & 562 & & 369.0 & 148.0 & & 82 & 2.0 & & 320.0 & 2150.0 & 150 & & 3740 & 3620 & 101 & & \\
\hline 885 & WA-21 & 6.6 & 442 & 19.0 & 260.0 & 102.0 & 0.380 & 16 & 0.7 & 0.3 & 380.0 & 1138.0 & 416 & 2.30 & 2740 & 2567 & 98 & & \\
\hline 886 & $W A-22$ & 8.0 & 847 & 21.0 & 79.0 & 47.0 & 0.150 & 9 & 0.9 & 0.1 & 536.0 & 1640.0 & 170 & 1.50 & 3140 & 3069 & 94 & & \\
\hline 887 & WA- -23 & 7.7 & 130 & 16.0 & 550.0 & 140.0 & 0.010 & 14 & 0.6 & & 116.0 & 1900.0 & 78 & 0.20 & 2890 & 2871 & 103 & & \\
\hline 888 & WA -23 & 7.2 & & & & & & & & & & & & & & & & & \\
\hline 889 & $W A-23$ & 7.4 & & & & & & & & & & & & & & & & & \\
\hline 890 & $W A-24$ & 7.1 & 484 & 7.0 & 637.0 & 154.0 & & 25 & 0.7 & 0.4 & 341.0 & 1930.0 & 694 & 0.30 & 4398 & 4074 & 100 & & \\
\hline 891 & WA -25 & 7.8 & 501 & 12.0 & 155.0 & 125.0 & & 17 & 0.6 & 0.2 & 167.0 & 1164.0 & 430 & 0.90 & 2646 & 2470 & 102 & & \\
\hline 892 & $W A-26$ & 7.8 & 2110 & & 581.0 & 365.0 & & 17 & 1.6 & & 296.0 & 2790.0 & 1560 & & 6860 & 6570 & 100 & & \\
\hline 893 & $W A-27$ & 7.3 & 340 & 29.0 & 110.0 & 19.0 & & 20 & 0.2 & & 226.0 & 350.0 & 39 & 0.10 & & 443 & & & \\
\hline 894 & $W E-01$ & 8.1 & 7 & & 32.0 & 8.0 & & 11 & & & 135.0 & 10.0 & 6 & & 140 & 140 & 99 & & \\
\hline 895 & WE-01 & 7.2 & 12 & 2.0 & 14.0 & 5.5 & & 13 & & & 74.0 & 10.0 & 10 & 0.20 & 104 & 90 & 101 & & \\
\hline 896 & WE- 02 & & 16 & 2.0 & 53.0 & 14.0 & & & 0.1 & & 202.0 & 25.0 & 19 & & 259 & 228 & 104 & & \\
\hline 897 & WE- 03 & 7.6 & 20 & 3.0 & 56.0 & 17.0 & 0.010 & 16 & 0.1 & & 266.0 & 22.0 & 21 & 0.20 & 291 & 270 & 95 & & \\
\hline 898 & $W E-04$ & 8.3 & 44 & 2.0 & 47.0 & 10.0 & & & & & 173.0 & 54.0 & 35 & & 287 & 277 & 103 & & \\
\hline 899 & WE- 05 & 8.0 & 74 & 1.5 & 12.0 & 3.9 & & 18 & 0.1 & & 208.0 & 1.5 & 26 & 0.30 & 238 & 221 & 100 & & \\
\hline 900 & WE-06 & 7.6 & 19 & & 65.0 & 16.0 & 0.010 & 12 & & & & 32.0 & 23 & 0.10 & & 155 & 409 & & \\
\hline 901 & WE- 07 & 7.8 & 20 & 2.0 & 44.0 & 12.0 & 0.560 & 19 & & & 190.0 & 18.0 & 13 & 0.20 & 222 & 203 & 106 & & \\
\hline
\end{tabular}


$6 \tau-g$

\begin{tabular}{|c|c|c|c|c|c|c|c|c|}
\hline & $\begin{array}{l}\text { LLIT } \\
097\end{array}$ & & & $59 \tau$ & & $0: 066$ & & \\
\hline $\begin{array}{l}66 \\
66\end{array}$ & $\begin{array}{l}\tau 66 \tau \\
006 \tau\end{array}$ & $\begin{array}{l}066 \tau \\
056 \tau\end{array}$ & $\begin{array}{l}05 \cdot z \\
09 \cdot z\end{array}$ & $\begin{array}{l}8 \varepsilon \tau \\
0 \varepsilon \tau\end{array}$ & $\begin{array}{l}0.028 \\
0.028\end{array}$ & $\begin{array}{l}0.8 Z L \\
0.40 L\end{array}$ & $s \cdot 0$ & 8.0 \\
\hline & $060 \tau$ & & & $08 \tau$ & & $0.0 \angle L$ & & \\
\hline SOT & $\begin{array}{l}98 \angle \tau \\
\angle Z \sigma\end{array}$ & $0 \tau 6 \tau$ & $0 S^{\circ} z$ & $\begin{array}{l}0 \varepsilon \tau \\
\sigma \varepsilon\end{array}$ & $0.0 B L$ & $\begin{array}{l}0.079 \\
0.007\end{array}$ & & 9.0 \\
\hline IOT & $\begin{array}{l}\tau E \cdot 8 \angle \sigma \tau \\
\nabla L 6\end{array}$ & SZST & $8^{\prime} 2$ & $\begin{array}{l}\tau \tau \tau \\
\varepsilon S \tau\end{array}$ & 8SS & $\begin{array}{l}509 \\
0.969\end{array}$ & $\varepsilon \varepsilon \cdot 0$ & $\varepsilon S \cdot 0$ \\
\hline $\begin{array}{l}66 \\
66 \\
L 6 \\
86 \\
L 6\end{array}$ & $\begin{array}{l}599 \tau \\
56 \tau \\
567 \\
5 \varepsilon z \\
907 \\
6 \tau \nabla\end{array}$ & $\begin{array}{l}0 \varepsilon L \tau \\
9 \tau \tau \\
60 S \\
65 \tau \\
85 \% \\
8 L 7\end{array}$ & $\begin{array}{l}0 z \cdot z \\
0 z \cdot 0 \\
0 z \cdot 0 \\
05 \cdot 0 \\
08 \cdot 0\end{array}$ & $\begin{array}{l}80 \tau \\
9 \tau \\
\text { s0z } \\
\varepsilon \tau \\
L 8 \\
96\end{array}$ & $\begin{array}{l}0 \cdot \tau 99 \\
0 \cdot \tau \tau \\
5 \cdot \tau \\
b \cdot \tau \\
z \cdot \tau \\
8 \cdot 0\end{array}$ & $\begin{array}{l}0.7 L 9 \\
0 . \varepsilon 6 \tau \\
0.06 \tau \\
0.8 Z z \\
0.80 \varepsilon \\
0.0 \tau \varepsilon\end{array}$ & $\because$ & $\begin{array}{l}L \cdot 0 \\
\tau \cdot 0 \\
\tau \cdot 0\end{array}$ \\
\hline
\end{tabular}

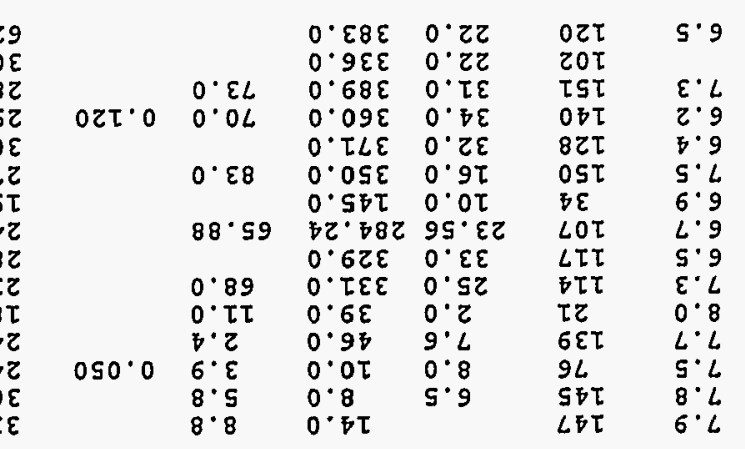

LO-SM DS6 90-SM $\Sigma 56$ S0-SM ZS6 B0-SM TS6 DO-SM 056 $60-5 M \quad 676$ $\varepsilon 0-5 M \quad 8 \nabla 6$ $20-5 M \quad 206$ $20-5 M \quad 966$ $\tau 0-5 M \quad 5 b 6$ $\tau \nabla-g M \quad \nabla \sigma \sigma$ $O D-3 M$ ED $6 \varepsilon-3 M$ $2 \nabla 6$ $\angle \varepsilon-3 M$ Ob6 $9 \varepsilon-3 M \quad 6 \varepsilon 6$

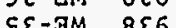

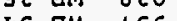
LEV T6 $\quad 06.0 \quad 68$

$0.6 \varepsilon \varepsilon$

$6 \cdot \tau \quad 0.5 \tau \quad 9.2$

LST

$\nabla \varepsilon-a M \quad L \varepsilon \sigma$ $\varepsilon \varepsilon-g M$ $9 \varepsilon \sigma$ $\tau \varepsilon-\exists M \quad \delta \varepsilon \sigma$ $0 \varepsilon-\exists M \quad \varepsilon \varepsilon \sigma$ $6 Z-\exists M \quad Z \varepsilon \sigma$ $82-\Xi M T \varepsilon \sigma$ 1Z-3M 056 $96 \quad 798 \quad$ TZ6 $0 L .0 \quad 058 \quad 0 . \tau-0.098$

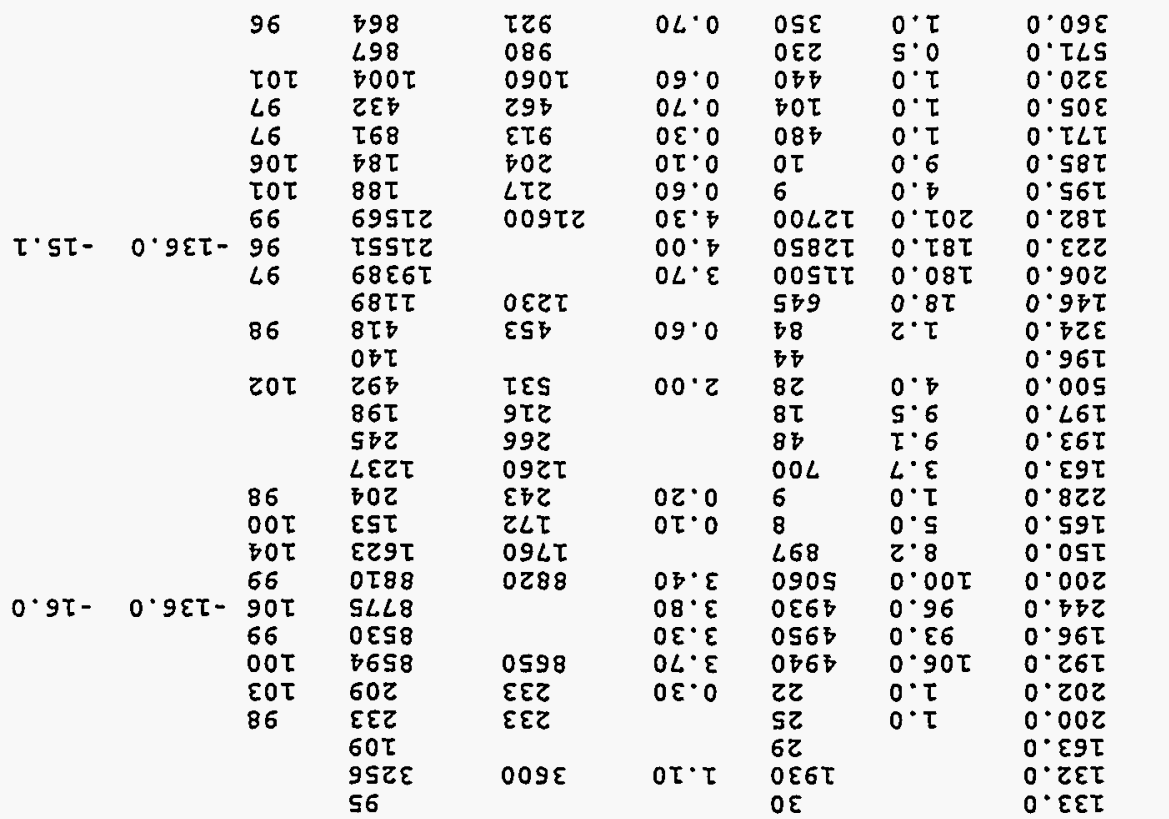

\begin{tabular}{|c|c|c|}
\hline & 00 & 85 \\
\hline & $\forall 0$ & $\begin{array}{l}49 \\
95\end{array}$ \\
\hline & $\tau \cdot 0$ & $z$ \\
\hline & $\tau \cdot 0$ & 62 \\
\hline S.OT & $I \cdot$ & $\begin{array}{l}82 \\
8 z \\
58\end{array}$ \\
\hline & $\nabla 0$ & $6 \tau$ \\
\hline & $\angle{ }^{\circ} O$ & $\begin{array}{l}52 \\
21 \\
6 I\end{array}$ \\
\hline & $\tau \cdot 0$ & $6 \varepsilon$ \\
\hline$L \cdot S$ & $\begin{array}{l}9^{\circ} \varepsilon \\
9^{\circ} \varepsilon\end{array}$ & $\begin{array}{l}\varepsilon S \\
\tau b \\
Z S \\
L b\end{array}$ \\
\hline & $\begin{array}{l}F^{\circ} 0 \\
\varepsilon^{\circ} 0\end{array}$ & $\begin{array}{l}82 \\
52\end{array}$ \\
\hline
\end{tabular}

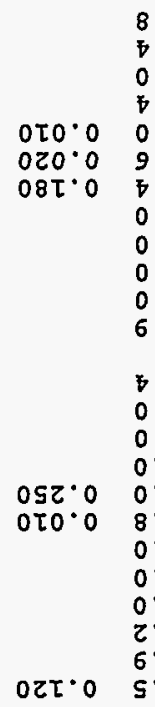

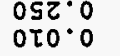

$0 z \tau \cdot 0$

$08 z$

$5 \cdot \frac{2}{8}$

LZ-gM 626 $\angle Z-\exists M \quad 8 Z 6$ $9 Z-9 M \quad$ LZG $s z-a M \quad 9 z 6$ bZ- $\mathrm{gM} \quad 526$ $\varepsilon Z-3 M$ \Z6 $z Z-g M \quad \varepsilon z \sigma$ $Z Z-3 M \quad Z Z 6$ $27-3 M$ TZ6 $2 \pi-9 M \quad 0 z 6$ $02-3 M \quad 6 \tau 6$ $6 T-9 M \quad B T 6$ $8 \tau-g M \quad L \tau$ $L T-g M$ gTE $9 \tau-\exists M$ sโ ST-TM

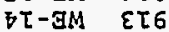
$\varepsilon \tau-3 M \quad Z I 6$ ZT-GM $\tau \tau \sigma$ $\tau \tau-\Xi M$ OT 6 IT-EM 606 $\tau \tau-\Xi M \quad 806$ โโ-JM 206 $0 \tau-3 M \quad 506$ OT- $\Xi M \quad \forall 06$ $60-3 M \quad \varepsilon 06$

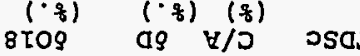

- $\varepsilon \varepsilon \tau$

ЕОЈH

g 20?5

$a$

$6 w$

eD $x$

EN

Hूd

ON dUW $a I$ 


\begin{tabular}{|c|c|c|c|c|c|c|c|c|c|c|c|c|c|c|c|c|c|c|}
\hline ID & MAP NO. & $\mathrm{pH}$ & $\mathrm{Na}$ & $\mathrm{K}$ & $\mathrm{Ca}$ & $\mathrm{Mg}$ & Fe & $\mathrm{SiO} 2$ & B & Li & $\mathrm{HCO} 3$ & $\mathrm{SO} 4$ & $\mathrm{Cl}$ & $\mathrm{F}$ & TDSm & TDSC & $\begin{array}{l}C / A \quad \delta D \\
(z)(z .)\end{array}$ & $\begin{array}{c}\delta 018 \\
(8 .)\end{array}$ \\
\hline 955 & WS -08 & 6.5 & 94 & 27.0 & 310.0 & & & 24 & & & 632.0 & & 120 & & & 862 & & \\
\hline 956 & WS - 09 & & 93 & 28.0 & 312.0 & & & 26 & & & 664.0 & & 125 & & & 884 & & \\
\hline 957 & WS -10 & & 98 & 25.0 & 336.0 & & & 26 & & & & & 125 & & & 584 & & \\
\hline 958 & $W Y=01$ & 7.6 & 1400 & 7.0 & 250.0 & 65.0 & 0.030 & 10 & 0.3 & & 226.0 & 1000.0 & 1900 & 0.50 & 4710 & 4734 & $100-114.0$ & -15.2 \\
\hline 959 & $W X-02$ & 8.1 & 84 & 6.0 & 68.0 & 25.0 & & 45 & 0.5 & & 270.0 & 160.0 & 47 & 0.40 & 569 & 523 & 101 & \\
\hline 960 & $W Y-03$ & 7.8 & 494 & 4.4 & 284.0 & 88.0 & & 13 & & & & 1070.0 & 625 & 0.40 & 3746 & 2566 & & \\
\hline 961 & $W Y-04$ & 8.4 & & & & & & & & & & & & & & & & \\
\hline 962 & $W Y-05$ & 6.4 & 27 & 1.0 & 87.0 & 15.0 & 0.050 & 17 & & & 170.0 & 170.0 & 7 & 0.40 & 409 & 391 & 103 & \\
\hline 963 & WY-06 & & 39 & 1.1 & & & & 21 & 100.0 & & 210.0 & 180.0 & 6 & 0.90 & 459 & 330 & & \\
\hline 964 & WY -06 & & 39 & 1.0 & 89.0 & 18.0 & & 21 & 0.1 & & 210.0 & 180.0 & 6 & 0.90 & 472 & 437 & 103 & \\
\hline
\end{tabular}




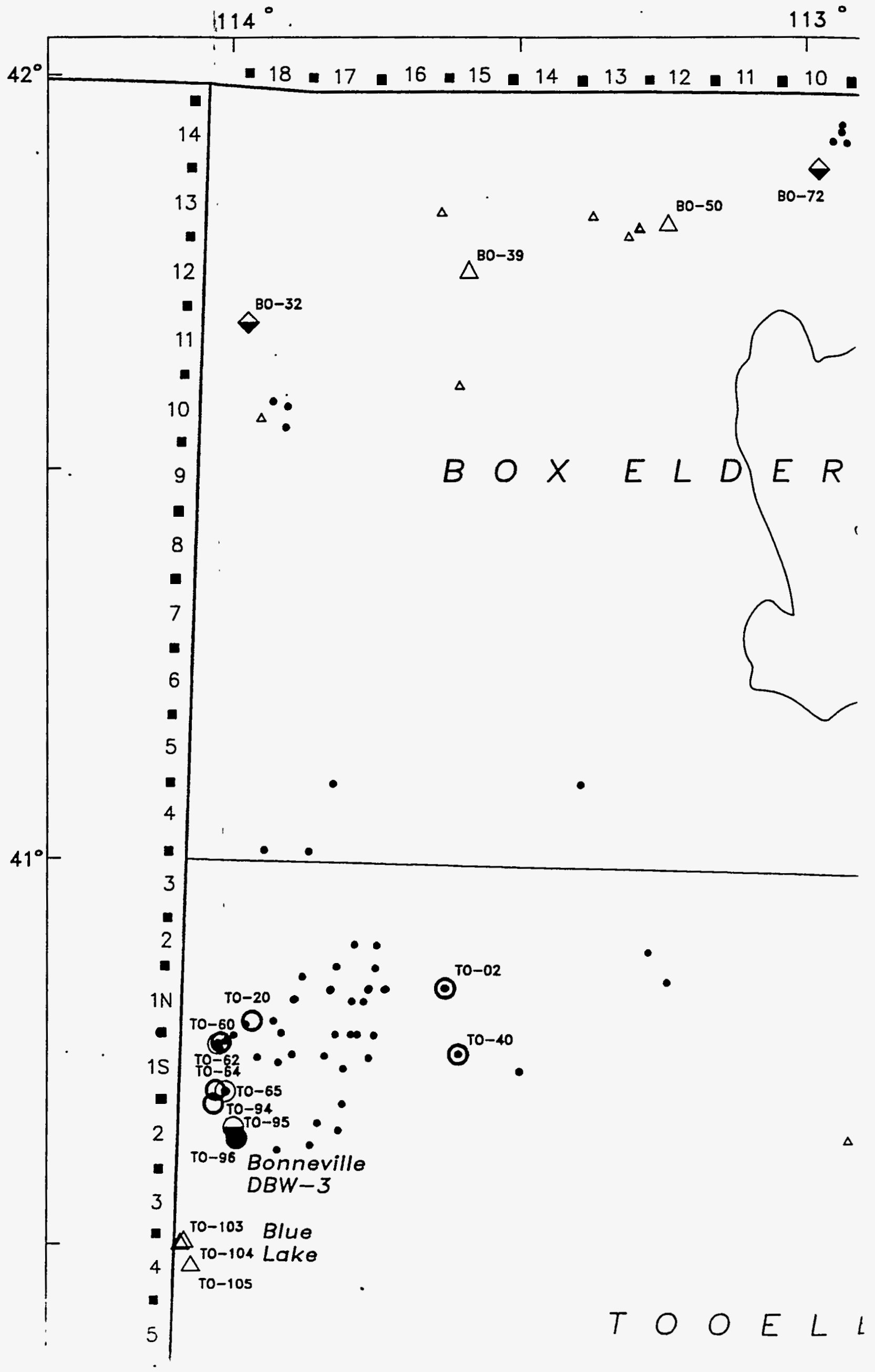




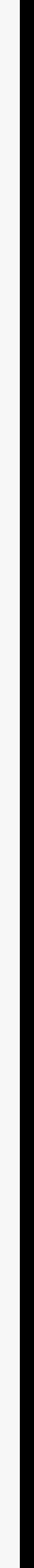




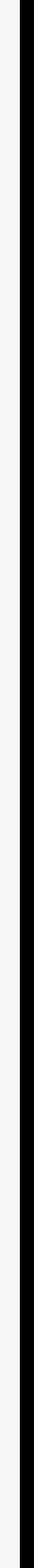




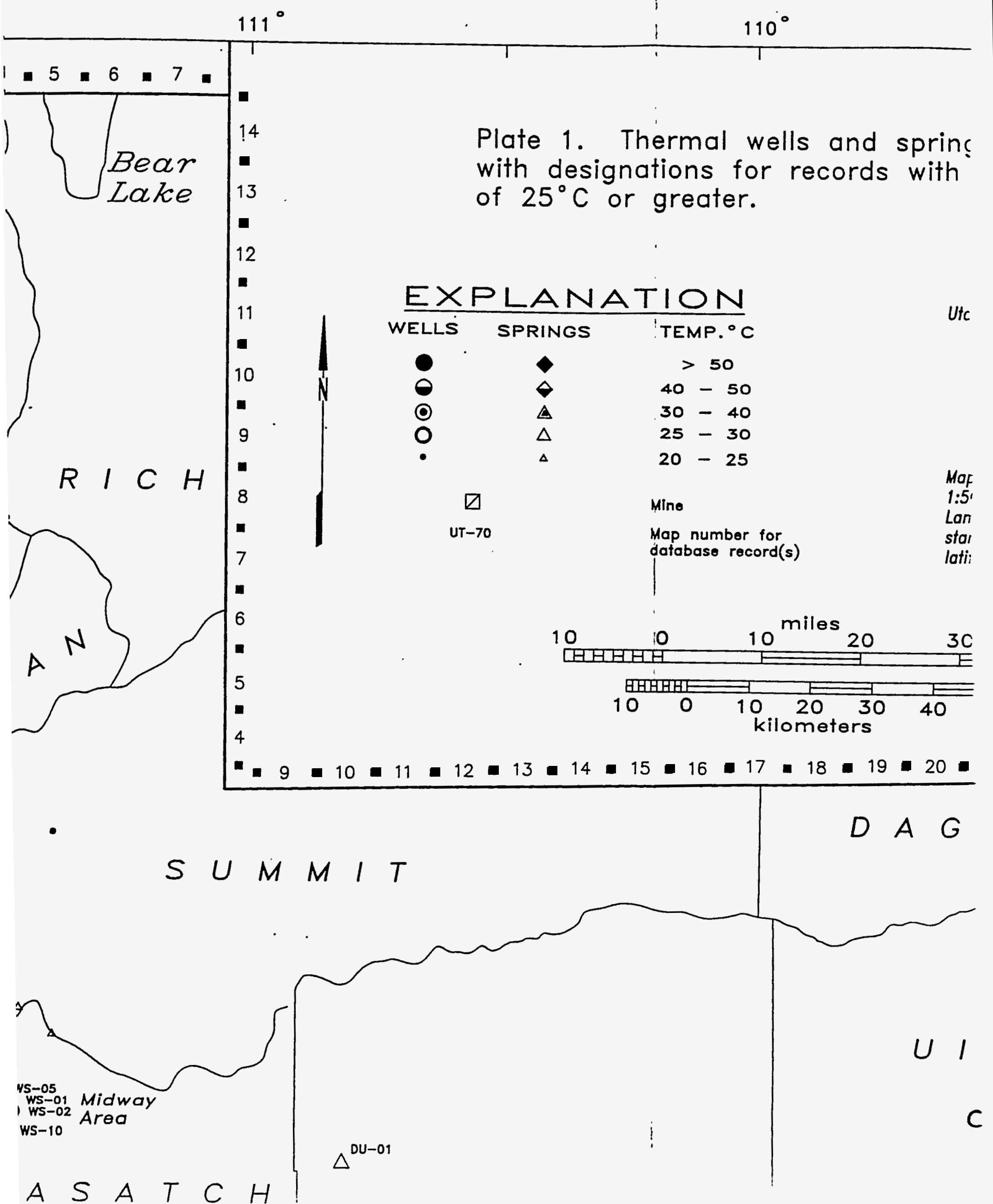




A


hermal wells and springs in Utah ations for records with temperatures greater.

\begin{tabular}{c}
$T I O N$ \\
\hline TEMP. ${ }^{\circ} \mathrm{C}$ \\
$>50$ \\
$40-50$ \\
$30-40$ \\
$25-30$ \\
$20-25$
\end{tabular}

Mine

Map number for database record(s)
Prepared by:

Utah Department. of Natural Resources Utah Geological Survey

Salt Lake City, Utah

Map based on U.S. Geological Survey 1:500,000 topographic base, 1988. Lambert Conformal Conic Projection with standard parallels 33 and 45 degrees latifude.
(1)
miles
0
20
30
40

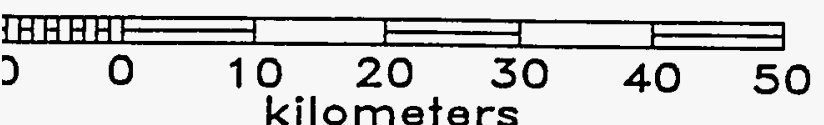

$18 \cdot 19 \cdot 20 \cdot 21 \cdot 22$

- 23

- 24

- 25

$D A G G E T T$

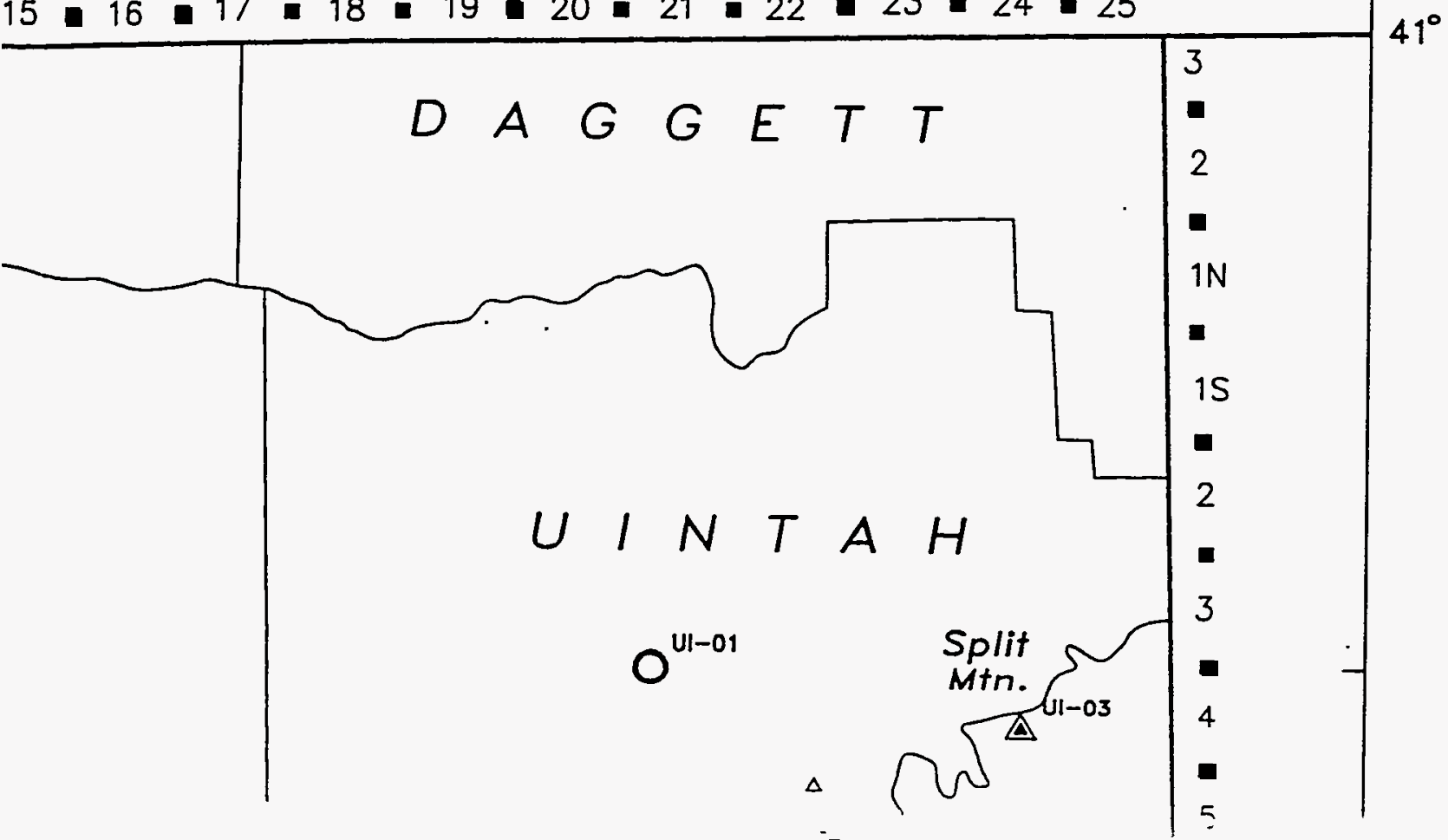




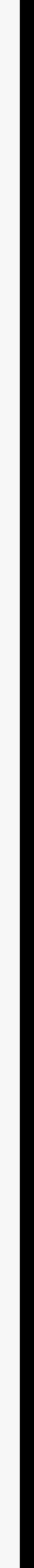


TOOELE

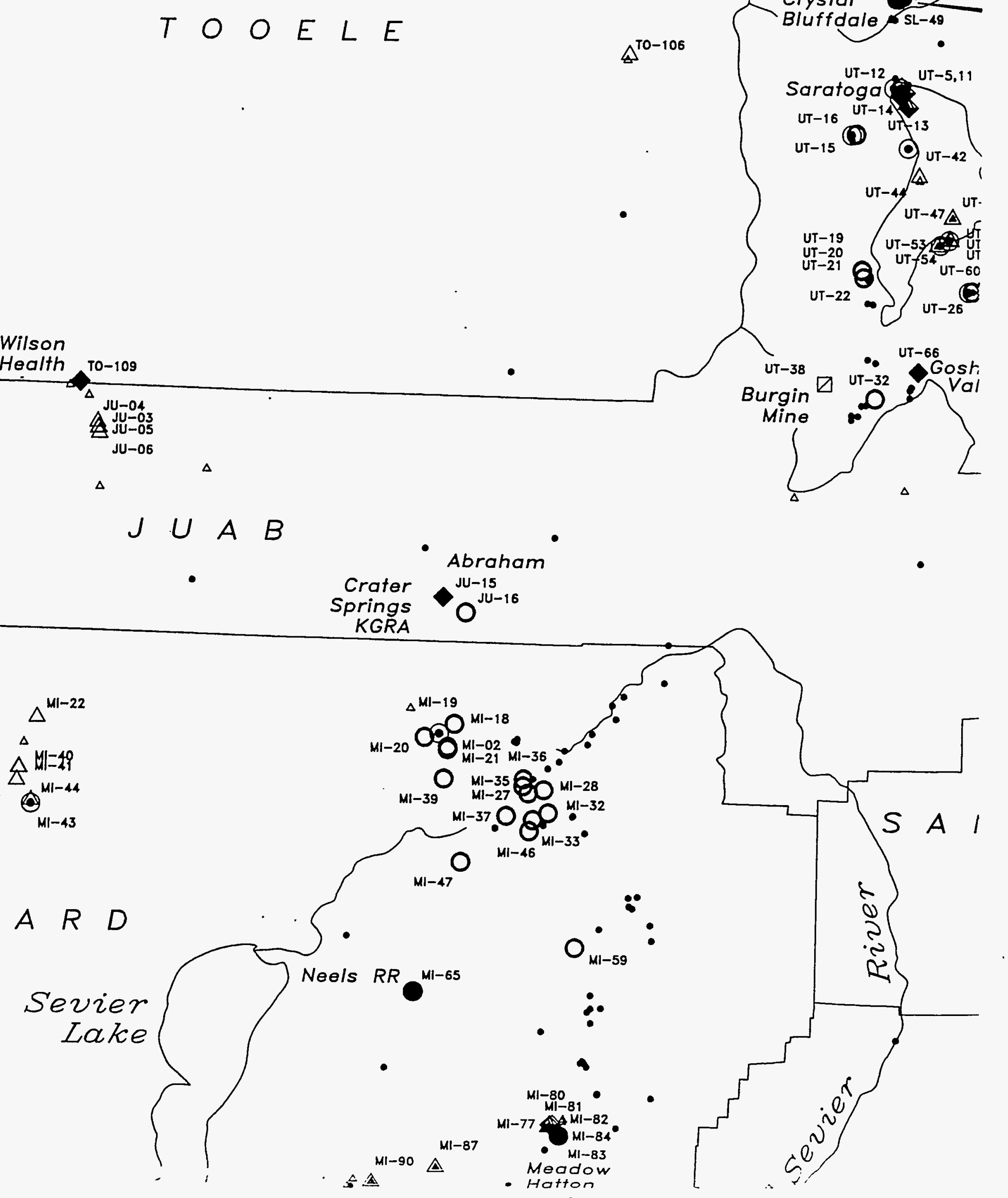


. 


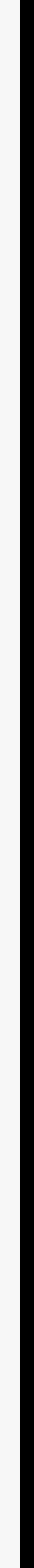




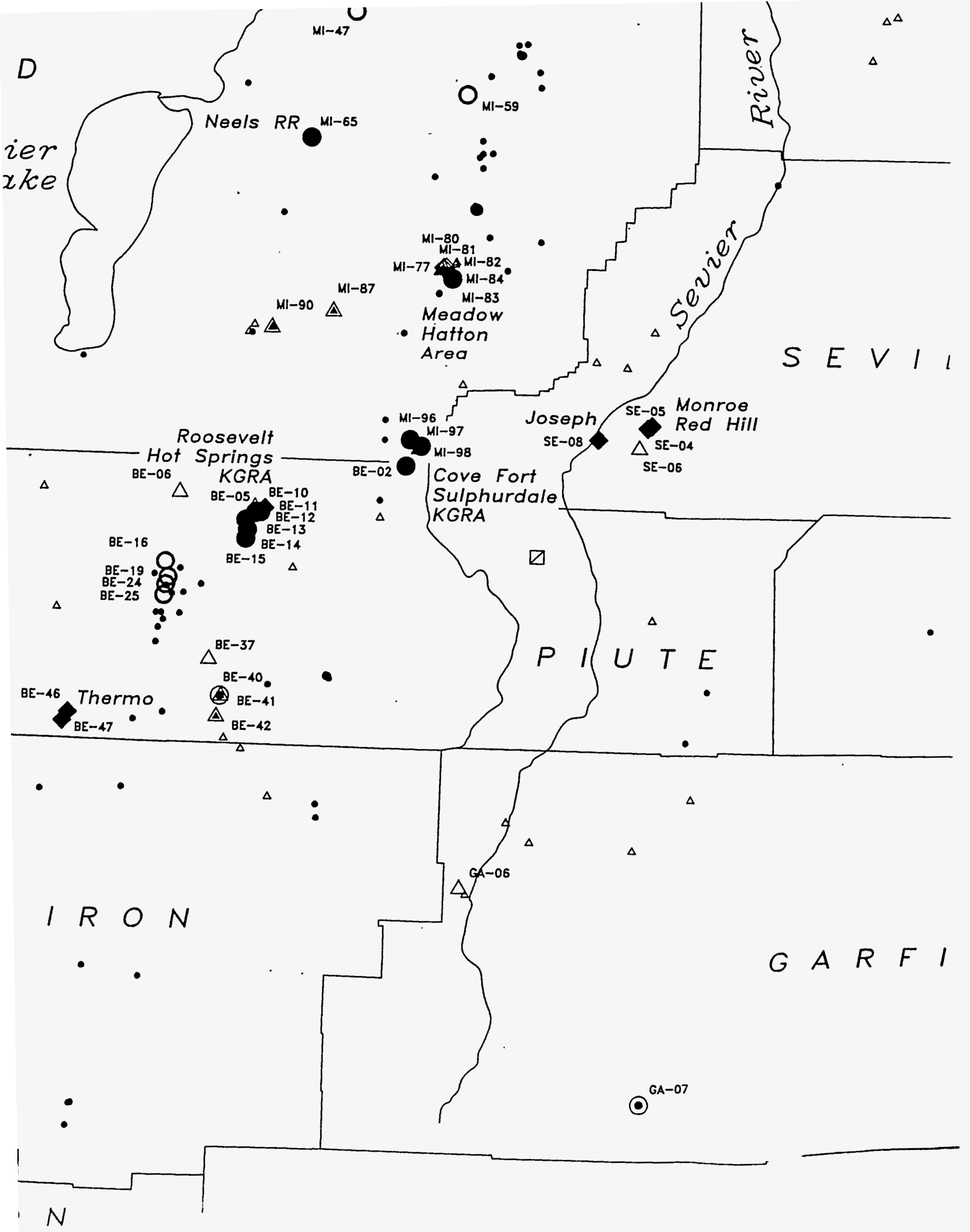




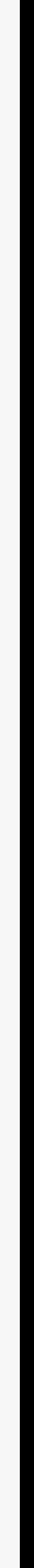



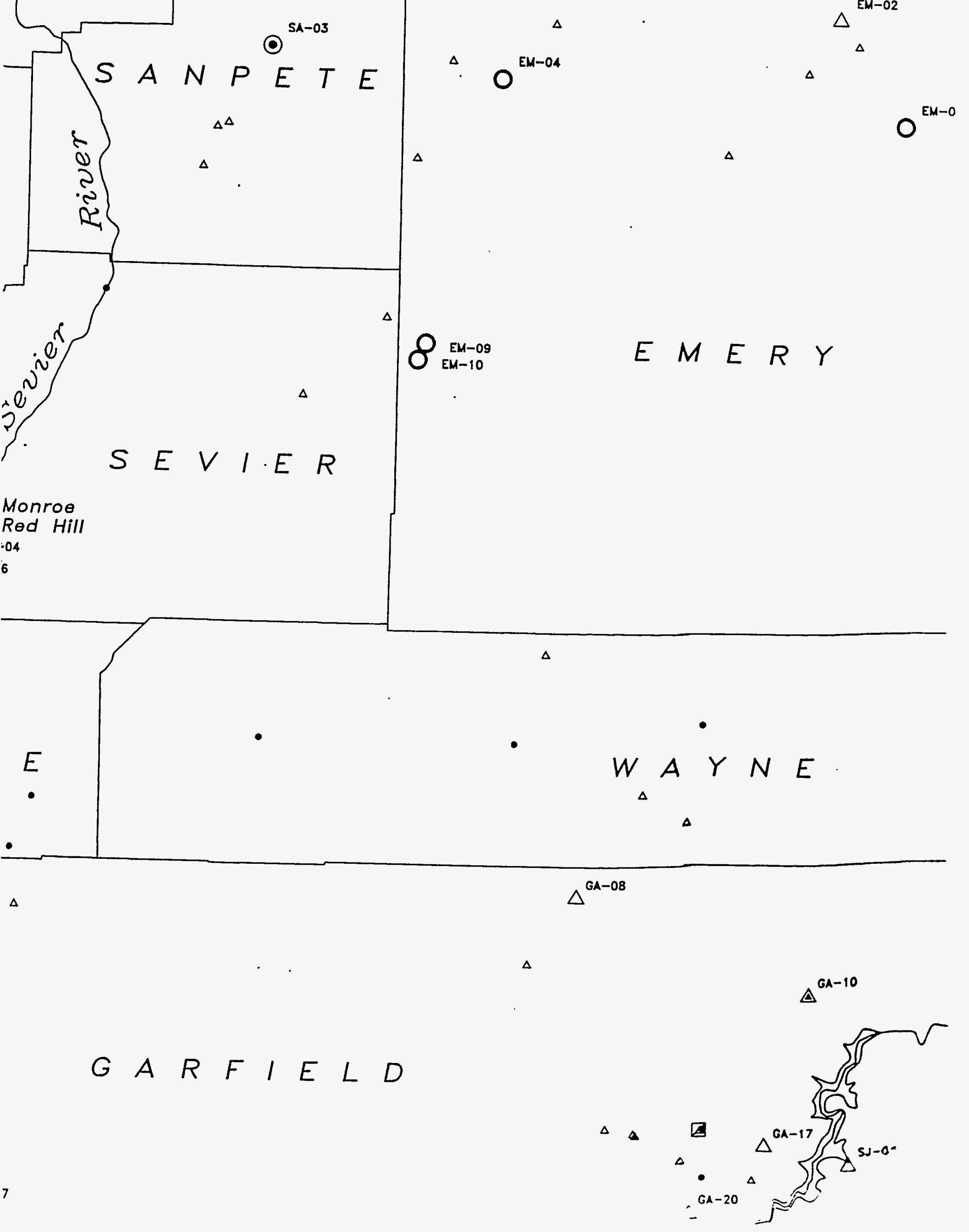


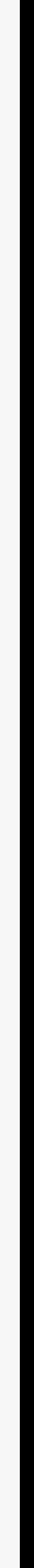




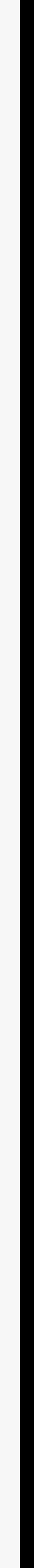




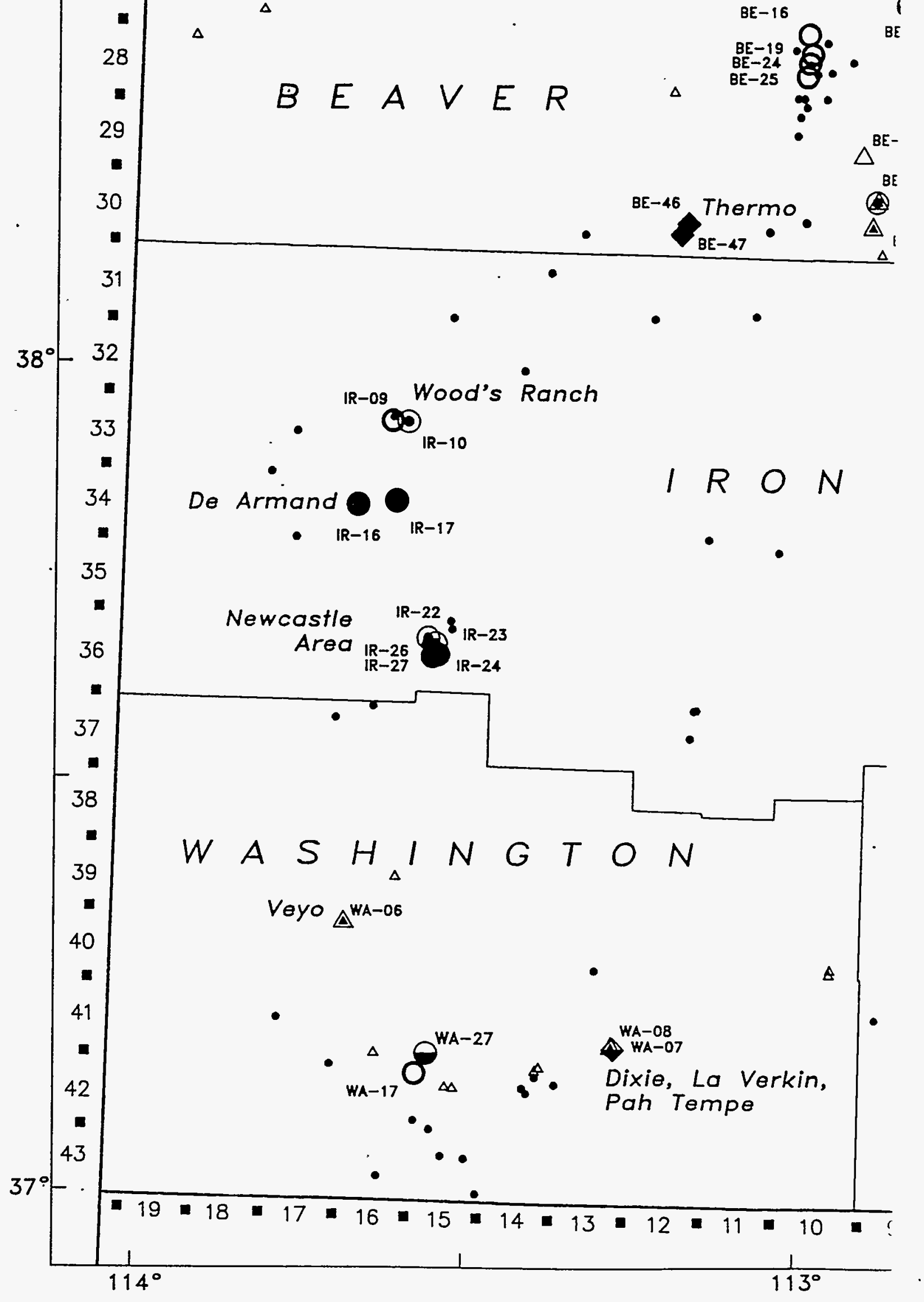





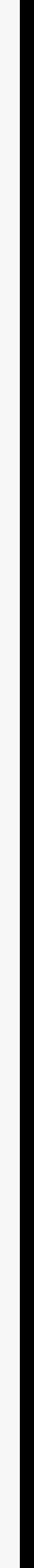





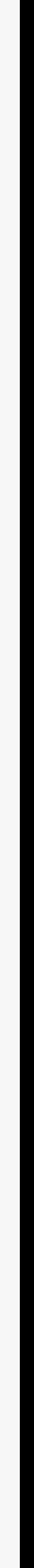




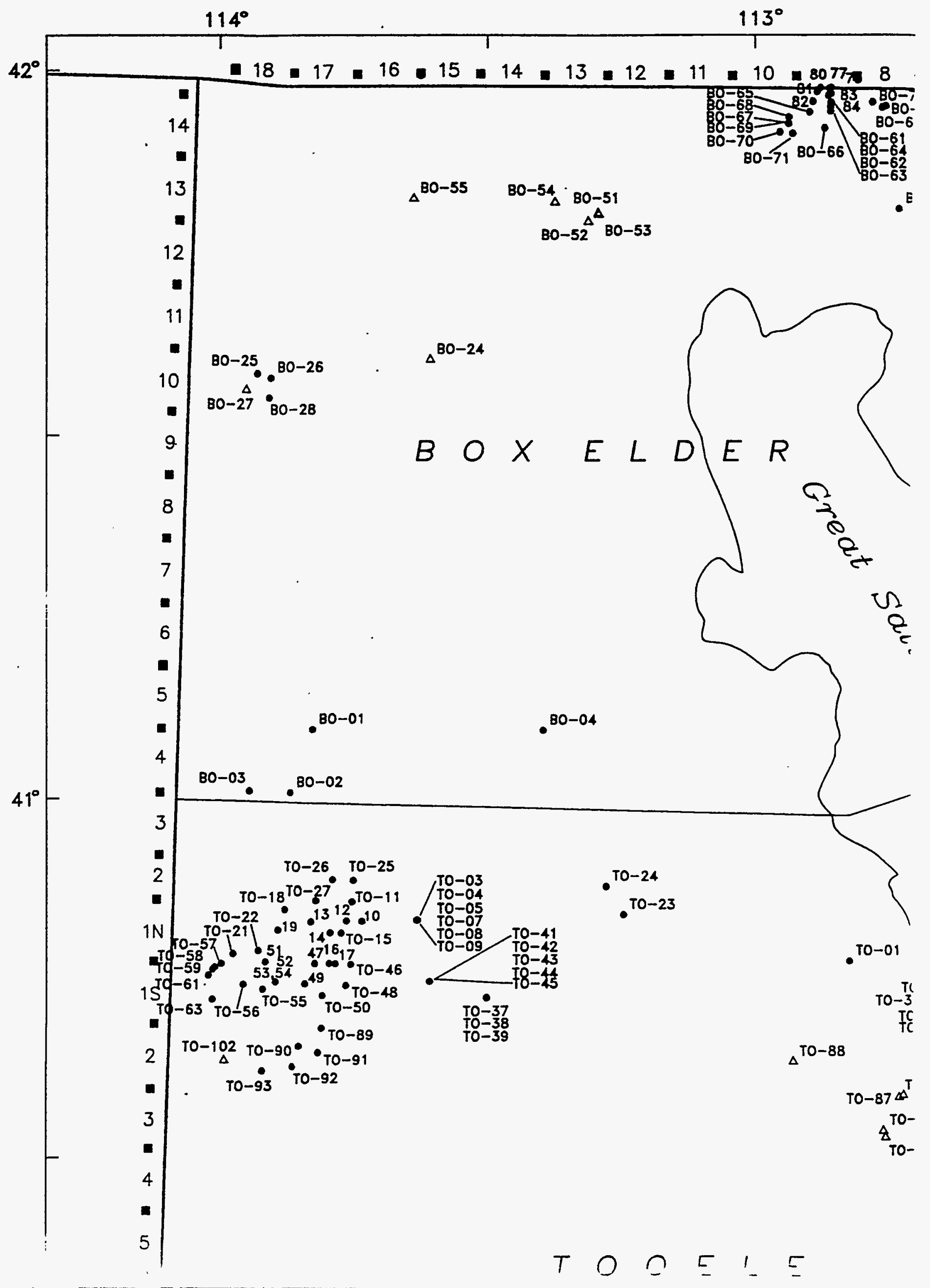




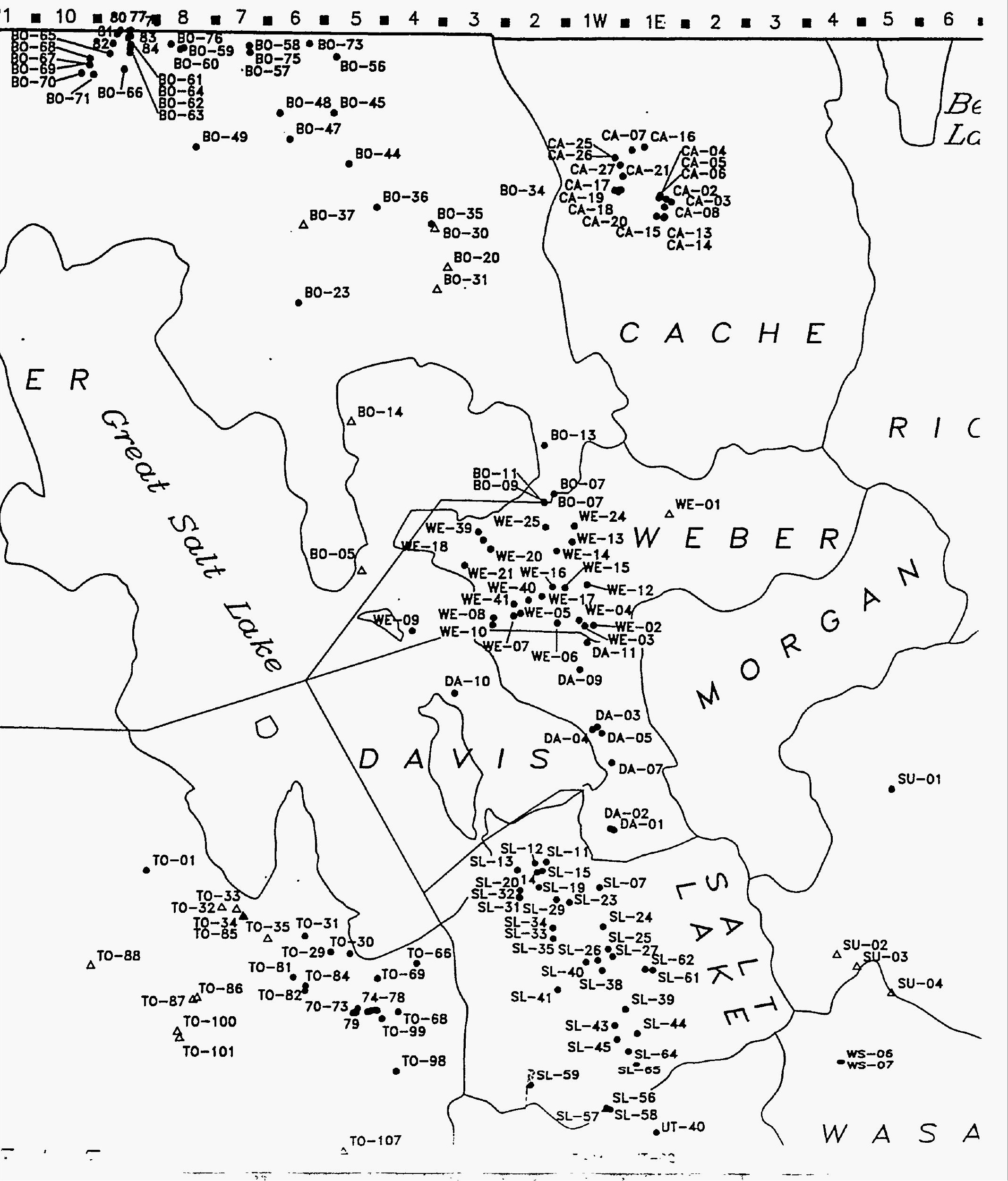




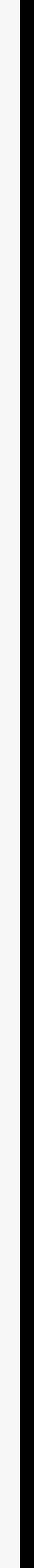




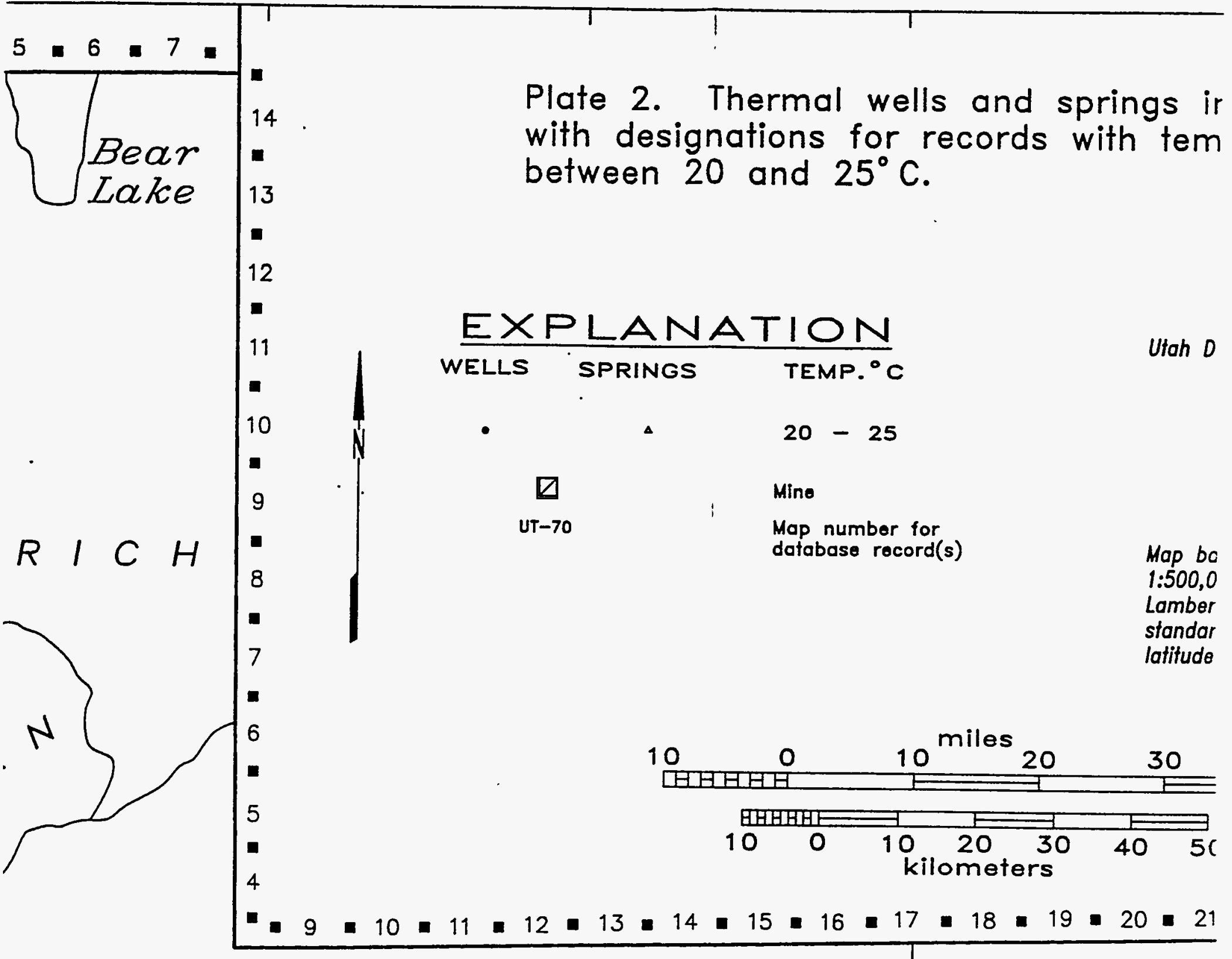

SU-01

$S U M M I T$

$D A G$ 


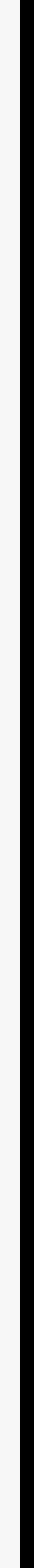


te 2. Thermal wells and springs in Utah n designations for records with temperatures ween 20 and $25^{\circ} \mathrm{C}$.

\section{$\frac{\text { LANA TION }}{\text { SPRINGS }}$}

$\triangle \quad 20-25$

Mine

Map number for database record(s)
Prepared by:

Utah Department of Natural Resources Ufah Geological Survey

Salt Lake City, Utah
Hap based on U.S. Geological Survey 1:500,000 topographic bose, 1988. Lambert Conformal Conic Projection with standard parallels 33 and 45 degrees latifude.

$10 \quad 10^{\text {miles }} 20 \quad 30 \quad 40$

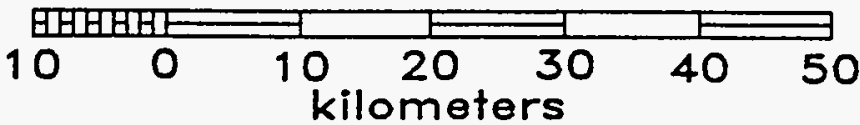

$D A G G E T T$

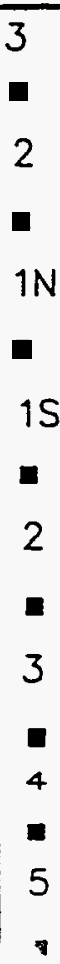




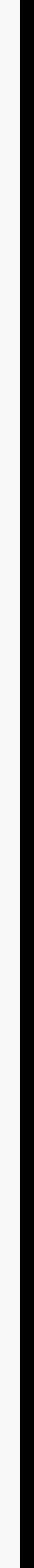




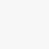


$T O O E L E$<smiles>[B]</smiles>

MI-04

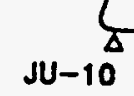

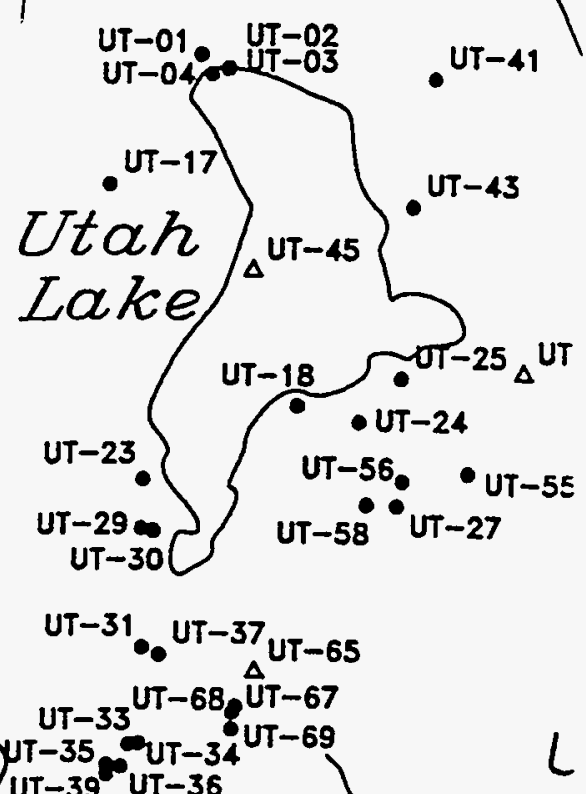
UT-41
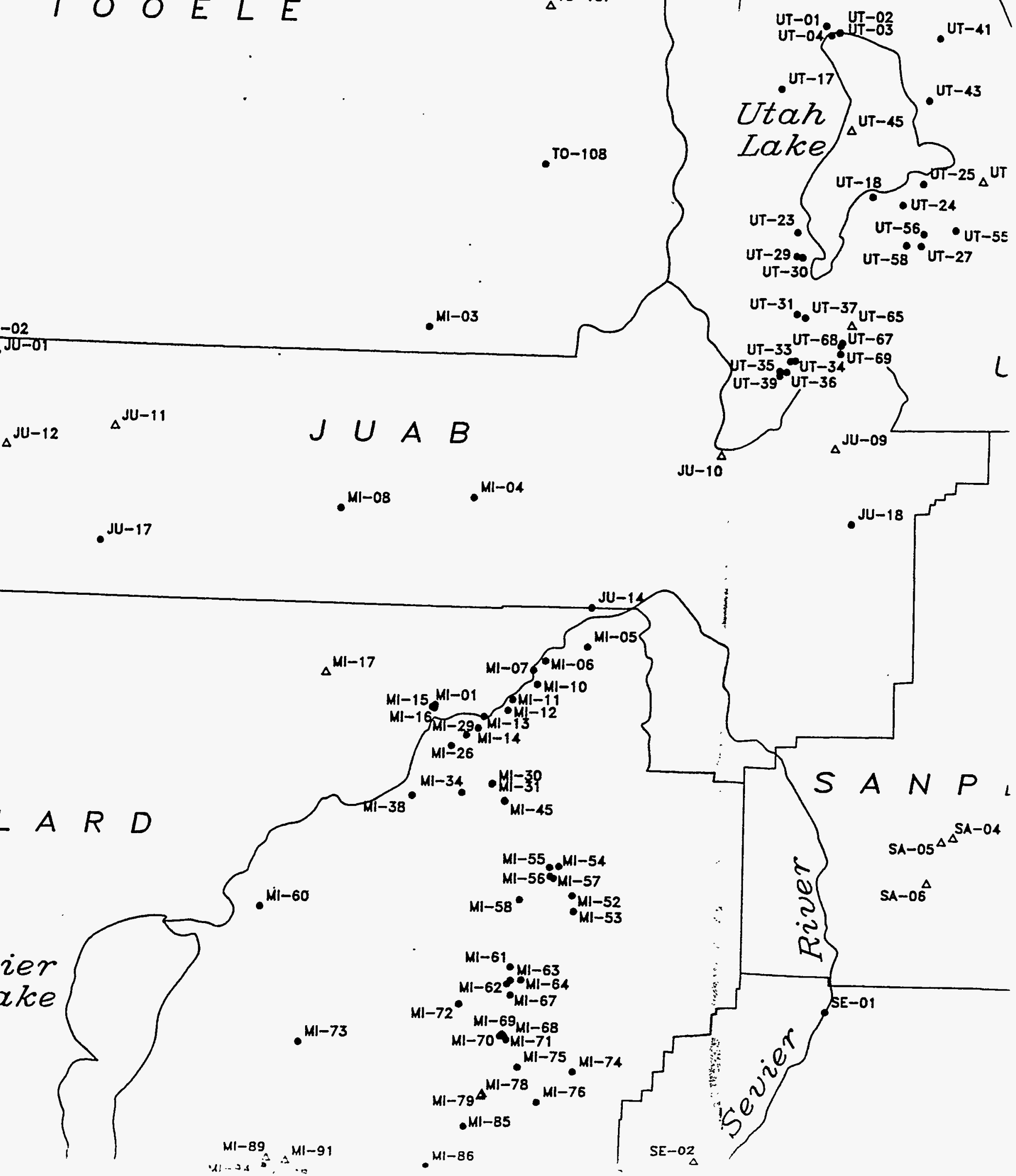


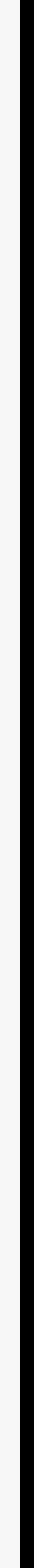




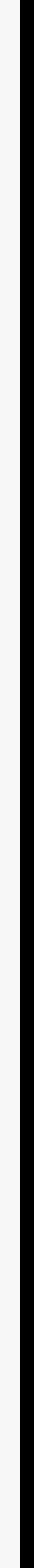





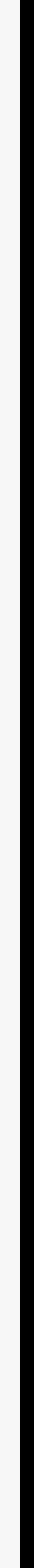




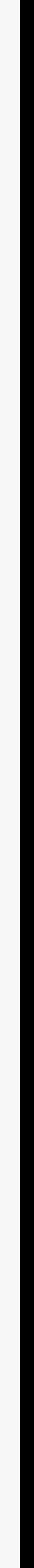





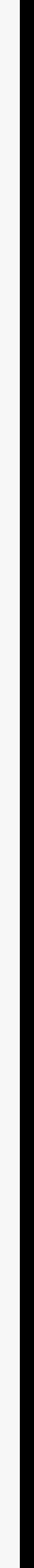




\section{$A N P E T E \Delta^{E M-03}$}

$\Delta^{E M-05} \Delta^{E M-06}$

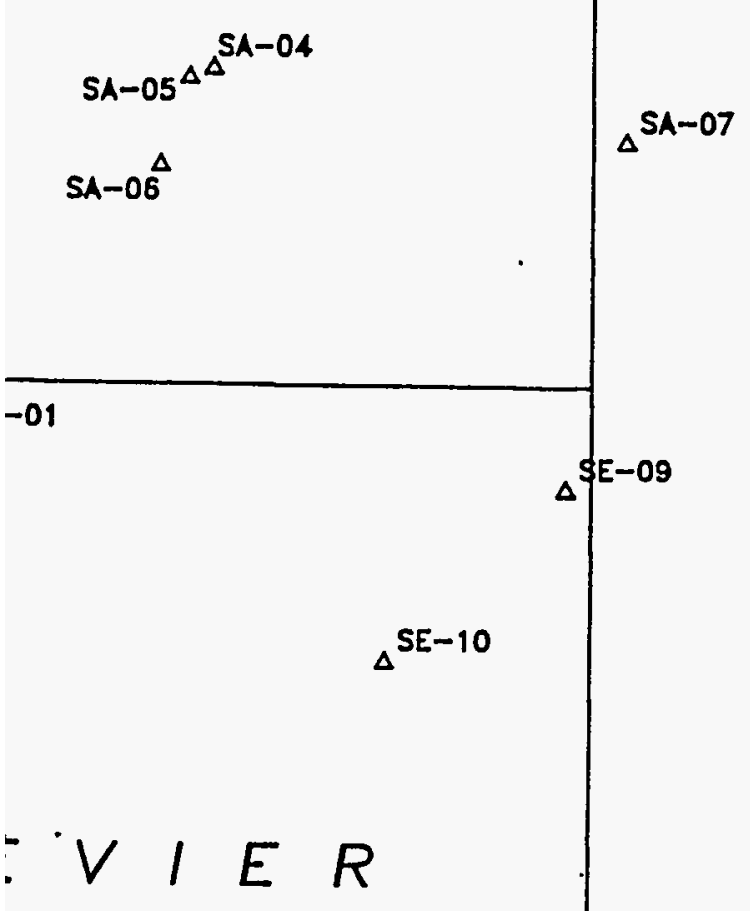

\section{EMERY}

$\Delta^{E M-07}$

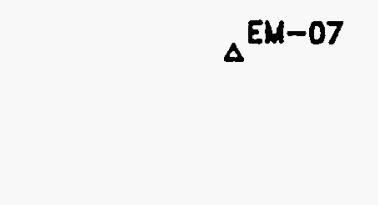

.WY-02 .WY-03

- wr-04

$W A Y N E$

$\Delta^{H Y-05}$

$\Delta^{W Y-06}$

$G A R F \mid E L D$

$\Delta^{\text {GA-09 }}$

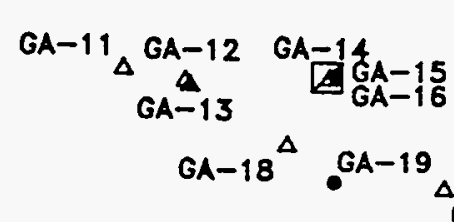




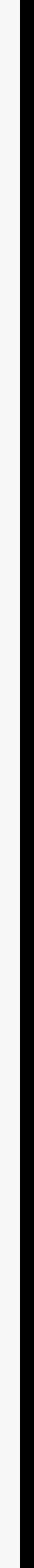




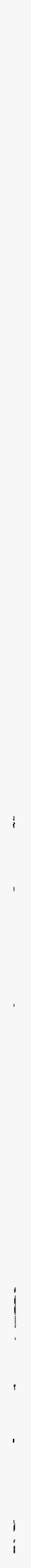





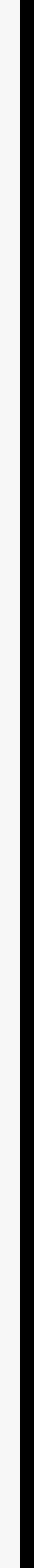




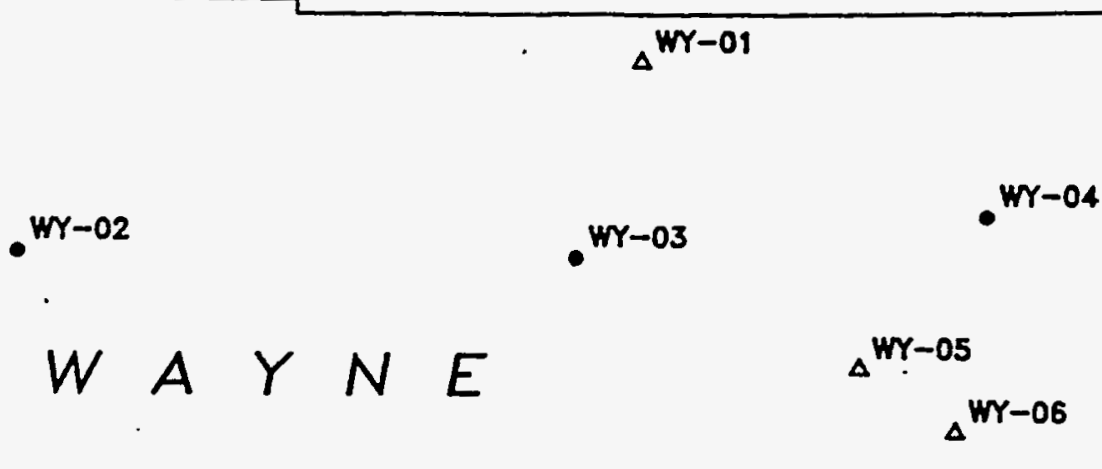

$-01$

$\Delta^{G A-09}$

$G A R F \mid E L D$

$+N E$

- KA-04

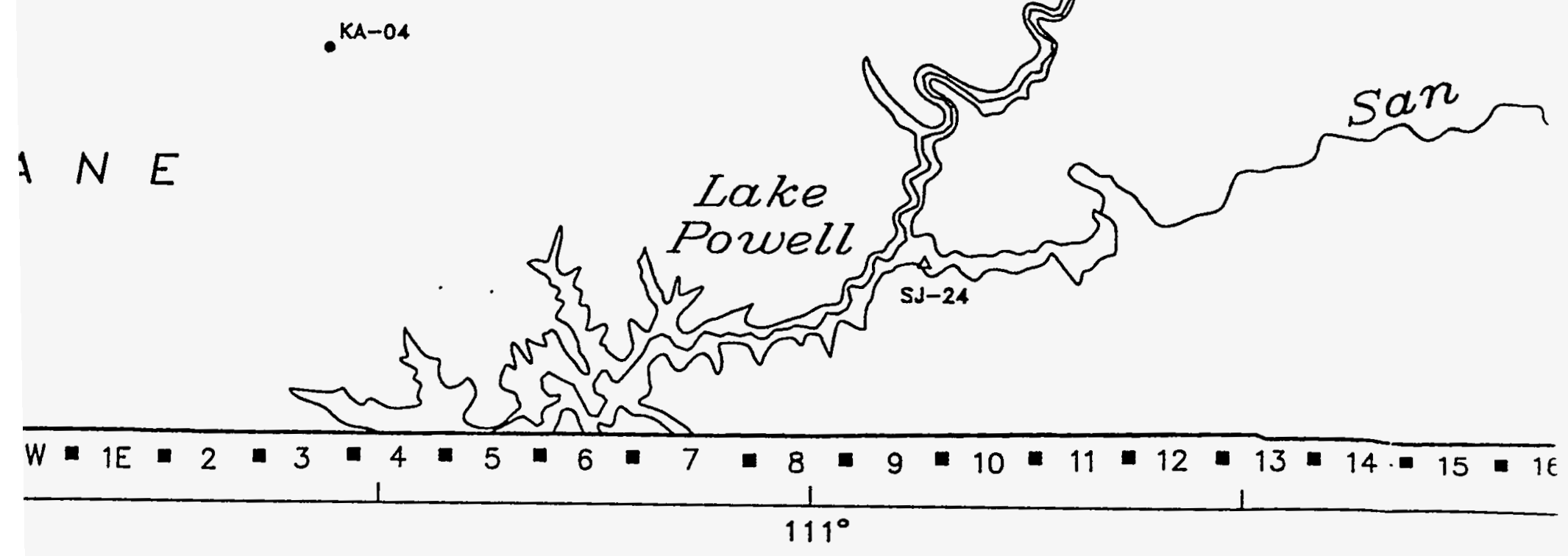




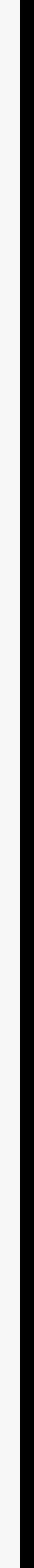




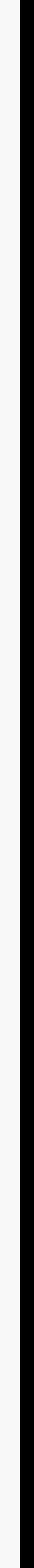

